\title{
A COMBINED MICROPALEONTOLOGICAL AND STRONTIUM ISOTOPE METHODOLOGY AS A PALEOCEANOGRAPHIC TOOL
}

\author{
by \\ Eduard G. Reinhardt, B.A. \\ $=$
A thesis submitted to the Graduate Studies and Research
in partial fulfilment of
the requirements for the degree of
Doctor of Philosophy . \\ Ottawa-Carleton Geoscience Centre \\ and \\ Department of Earth Sciences
}
Carleton University
Ottawa, Ontario

September, 1996.

(C) 1996 Eduard Reinhardt 
The author has granted an irrevocable non-exclusive licence allowing the National Library of Canada to reproduce, loan, distribute or sell copies of his/her thesis by any means and in any form or format, making this thesis available to interested persons.
L'auteur a accordé une licence irrévocable et non exclusive permettant à la Bibliothèque nationale du Canada de reproduire, prêter, distribuer ou vendre des copies de sa thèse de quelque manière et sous quelque forme que ce soit pour mettre des exemplaires de cette thèse à la disposition des personnes intéressées.

L'auteur conserve la propriété du droit d'auteur qui protège sa thèse. Ni la thèse ni des extraits substantiels de celle-ci ne doivent être imprimés ou autrement reproduits sans son autorisation. 
Name EDUARD \& REINhARDT

Dissertation Abstracts International is arranged by broad, general subject categories. Please select the one subject which most nearly describes the content of your dissertation. Enter the corresponding four-digit code in the spaces provided.

\section{GEOCHEMISTRY}

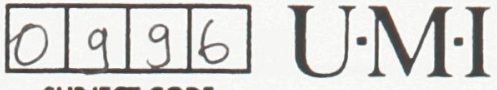

SUBJECT CODE

\section{Subject Categories}

\section{THE HUMANITIES AND SOCIAL SCIENCES}

\section{COMIIUNICATIONS AND THE ARTS}

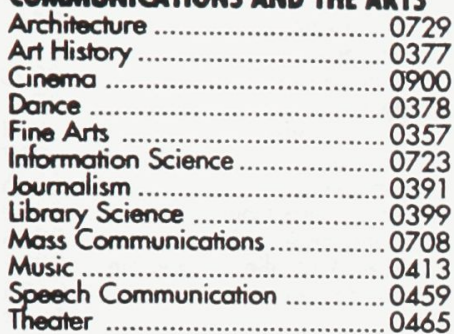

\section{EDUCATION}

General ...................................0515

Administration …........................0514

Adult and Continuing .................0516

Agricultural ............................. 0517

Ant ....................................... 0273

Bilingual and Multicultural ..........0282

Business .................................0688

Community College...

Curriculum and Instruction .........0727

Earty Childhood ..........................0518

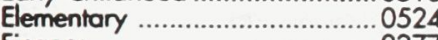

Finance ...............................0277

Guidance and Counseling ..........0519

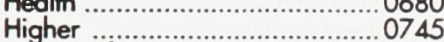

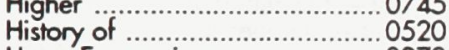

Home Economics .......................0278

Industrial ................................0521

Language and Literature .............0279

Mathematics ….............................

Music ........................................... 0522

Philosophy of ............................... 0998

Physical ........................................ 0523

\section{THE SCIENCES AND ENGINEERING}

\section{BIOLOGICAL SCIENCES}

Agriculture

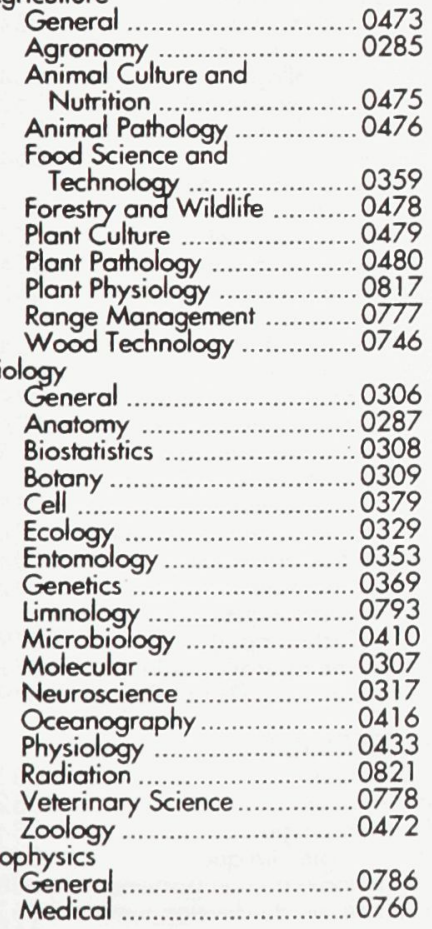

EARTH SCIENCES

Biogeochemistry

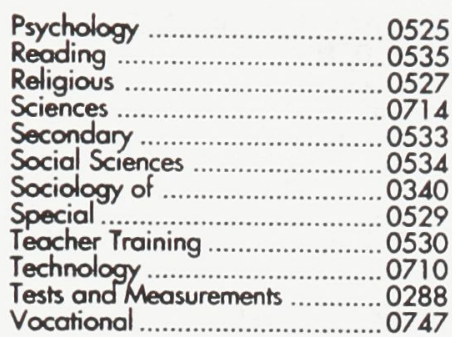

\section{LANGUAGE, LITERATURE AND UNGUISTICS}

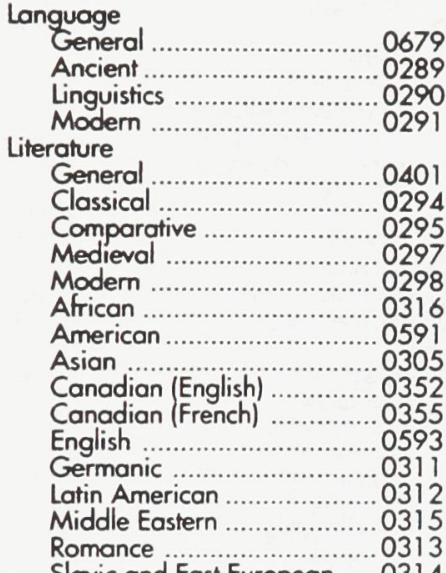

0298

0591

0305

0355

0593

(1)

(1)

\section{PHILOSOPHY, RELIGION AND \\ THEOLOGY}

Philosophy

Religion

General .......................... 0318

Biblical Studies ..................... 0321

History of ................................ 0320

Philosophy of ..................... 0322

Theology

0469

\section{SOCIAL SCIENCES}

American Studies

Anthropology

Archoeology ....................... 0324

Cultural 0326

Physical ……….......................... 0327

Business Administration

General ....

Accounting

0272

Banking ...................... 0770

Management ........................... 045

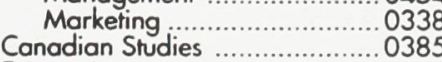

Economics

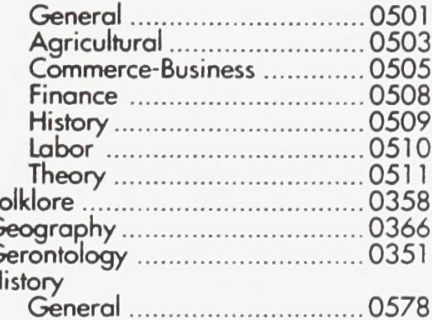

General

Slavic and East European .....0314
Ancient

Medieval

Modern

Black

African .

and Oceania 0332

Cangdian

European ...

Latin American

Middle Eastern

United States

0337

Low

Political Science

General .

International Low and

Relations

Public Administration

Recreation

Social Work

Sociology

General ..................... 0626

Criminology and Penology ... 0627

Demography 0938

Ethnic and Racial Studies ..... 0631

Individual and Family

Studies

Industrial and Labor

Relations

Public and Sociol Welfore...

Social Structure and

Development

Theory and Methods

Transportation

0709

Urban and Regional Planning ....0999

Women's Studies

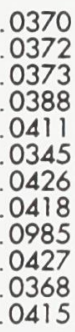

Geodesy

Geology .....

Hydrology

Mineralogy

Paleobotany

Paleoecology

Paleozoology

Palynology

Physical Geography

HEALTH AND ENVIRONMENTAL

SCIENCES

Environmental Sciences

Health Sciences

\begin{tabular}{|c|c|}
\hline 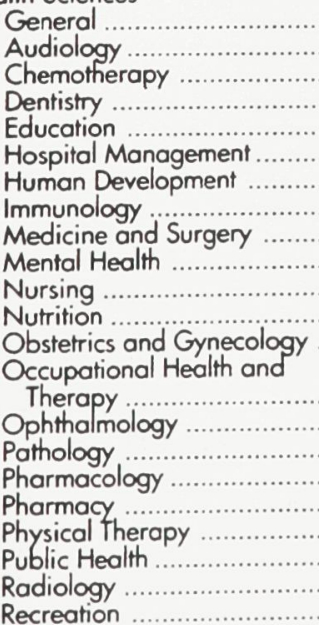 & \\
\hline
\end{tabular}

Speech Pathology .

Toxicology

Home Economics

\section{PHYSICAL SCIENCES}

Pure Sciences

Chemistry

General .

Agricultural

Analytical

Biochemistry

Inorganic

Nuclear

Organic.

Pharmaceutical

Physical

Polymer

Radiation

Mathematics

Physics

General

Acoustics

Astronomy and

Astrophysics

Atmospheric Science

Atomic

Electronics and Electricity

Elementary Particles and

High Energy

Fluid and Plasma

Molecular

Nuclear

Optics

Radiation

Solid State

Statistics

Applied Sciences

Applied Mechanics

Computer Science
0460

0386

Engineering

General .....

Agricultura

Automotive

Biomedical

Chemical

Civil

Electronics and Electrical

0544

Hydraulic 0545

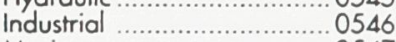

Marine ............................... 0547

Materials Science ................. 0794

Mechanical _........ 0548

Metallurgy ..............................0743

Mining …............................... 0551

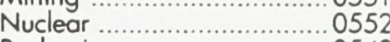

Packaging …................ 0549

Petroleum ........................ 0765

Sanitary and Municipal ........ 0554

System Science ................... 0790

Geotechnology .......................... 0428

Operations Research .................... 0796

Plastics Technology ................... 0795

Textile Technology

0994

PSYCHOLOGY

General

Behaviora

Clinical

Developmental

Experimental

Industrial

Personality

Physiological

Psychobiology

Psychometrics

Social

0621 
Nom

Dissertation Abstracts International est organisé en catégories de sujets. Veuillez s.v.p. choisir le sujet qui décrit le mieux votre thèse et inscrivez le code numérique approprié dans l'espace réservé ci-dessous.

\section{Catégories par sujets}

\section{MUMANITES ET SCIENCES SOCIALES}

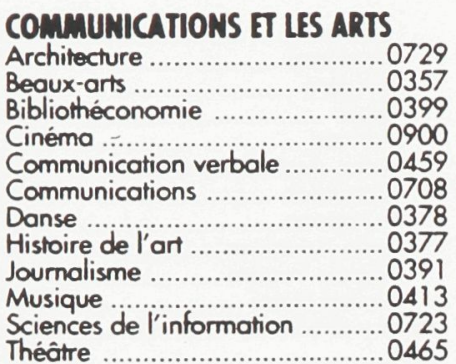

\section{EDUCATION}

Généralités ............................... 515

Administration ........................... 0514

Ant ...................................... 0273

Commerce .............................0688

Economie domestique ................... 0278

Education permanente ................0516

Education préscolaire ................. 0518

Enseignement ogricole .................... 0517

Enseignement bilingue et

mulficulturel

0282

Enseignement industriel ...............0521

Enseignement primaire. .............. 0524

Enseignement religieux ..............0527

Enseignement secondaire ........... 0533

Enseignement spécial .................0529

Enseignement supérieur ............. 0745

Evaluation ............................ 0288

Finances ............................... 0530

Histoire de l'éducation ............... 0520

Langues et litterature

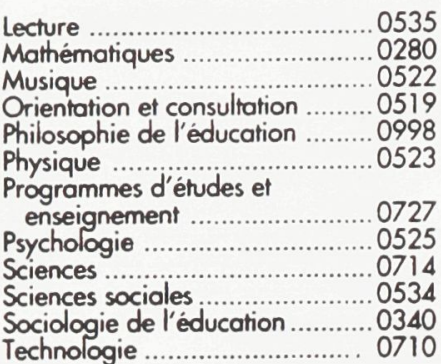

\section{LANGUE, LITTÉRATURE ET \\ LINGUISTIQUE}

Langues

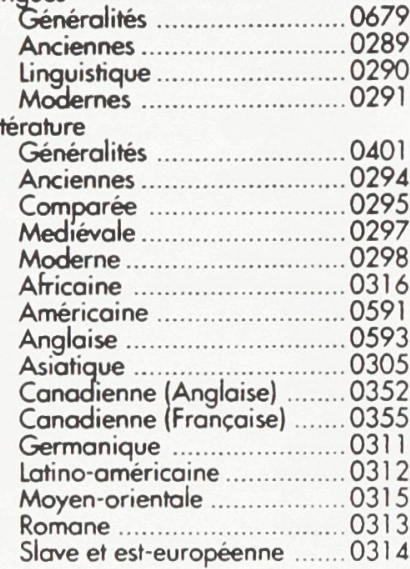

\section{SCIENCES ET INGENIERIE}

\section{SCIENCES BIOLOGIQUES}

Agriculture

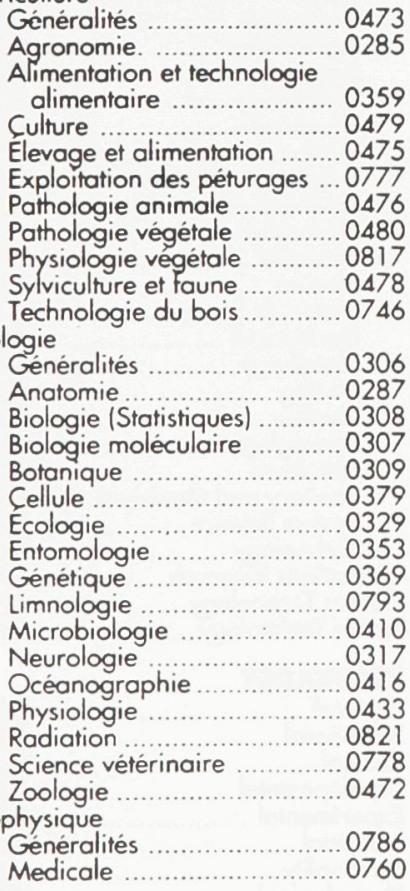

\section{SCIENCES DE LA TERRE}

Biogéochimie

Geochimie

Geodésie

\begin{tabular}{|c|}
\hline 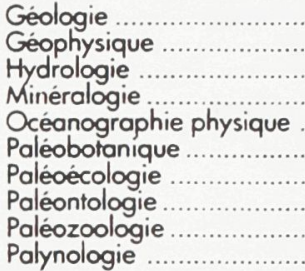 \\
\hline
\end{tabular}

\section{SCIENCES DE LA SANTÉ ET DE}

\section{L'ENVIRONNEMENT}

Économie domestique ...............0386

Sciences de l'environnement ...... 0768

Sciences de la santé

Généralités ................... 0566

Administration des hipitaux..0769

Alimentation et nutrition .......0570

Audiologie ...................... 0300

Chimiothérapie .................... 0992

Dentisterie ......................... 0567

Développement humain .......0758

Enseignement ....................... 0350

Immunologie ..................... 0982

Loisirs .............................. 0575

Médecine du travail et 0354

Médecine et chirurgie ........ 0564

Obstétrique et gynecologie ... 0380

Ophtalmologie ................... 038

Orthophonie ........................... 0460

Pathologie ........................057

Pharmacie ...................... 0572

Pharmacologie 0419

Physiothérapie 0382

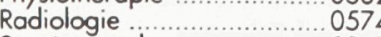

Santé mentale ....................... 0347

Santé publique .................. 0573

Soins infirmiers ................. 056

Toxicologie ..................... 0383

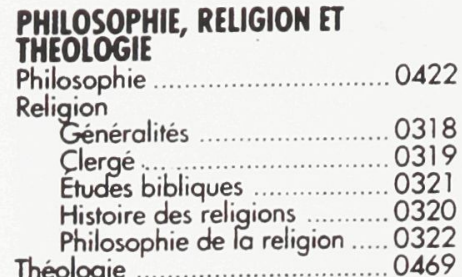

Theologie

0469

\section{SCIENCES SOCIALES}

Anthropologie

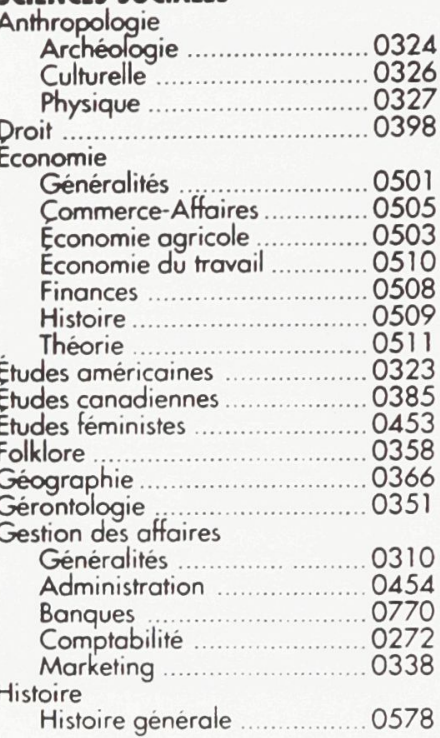

0319

0320

322

326

0398

0501

505

0510

0508

0509

323

0385

0453

366

0454

0770

338

Histoire generale

0578

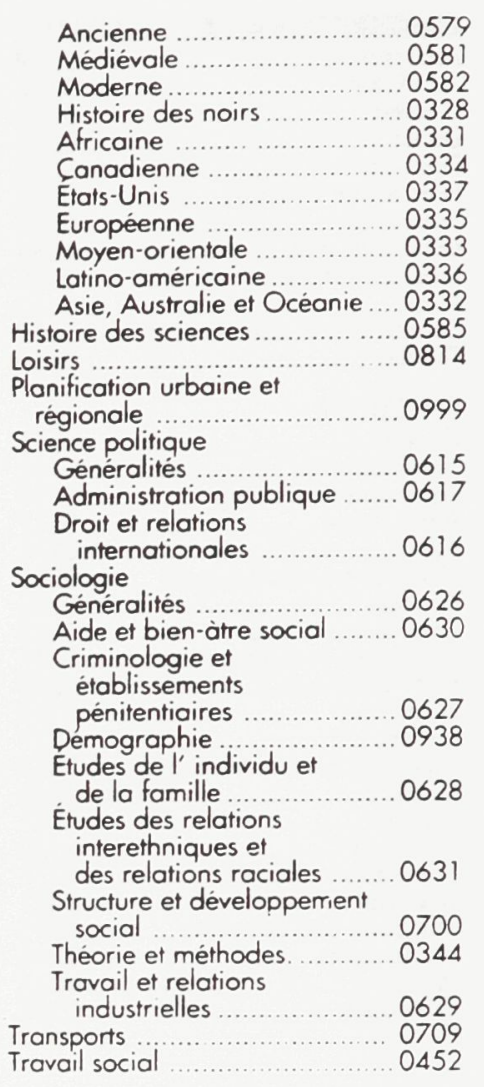

\section{SCIENCES PHYSIQUES}

Sciences Pures

Chimie

Generalités

Biochimie ..................... 0485

Chimie agricole ..................... 0749

Chimie analytique ................ 0486

Chimie minerale ................... 0488

Chimie nucléaire .................... 0738

Chimie organique ................ 0490

Chimie pharmaceutique ........0491

Physique ........................ 0494

Radiation ...................... 0495

Mathématiques .......................... 0405

Mathemotiq

Genéralités .......................0605

Acoustique

Astronomie et

astrophysique.

Electronique et électricite................

Fluides ef plasma ............... 0759

Météorologie ......................... 0608

Optique .............................. 0752

Particules (Physique

nucléaire)

0798

Physique atomique 0748

Physique de l'état solide ....... 0611

Physique moléculaire ........... 0609

Physique nucléaire ................ 0610

Statistiques ........................ 0463

Sciences Appliqués Et

Technologie

Informatique

Ingénierie

Générolités ...................... 0537
Agricole 0539
Automobile ............................ 0540

Biomédicale

Chaleur et ther

modynamique

Conditionnement

(Emballage)

Genie aérospatia

Genie chimique

Génie civil

Génie èlectronique et

électrique

Génie industriel

Génie mécanique

Génie nucléaire

Ingénierie des systämes

Mecanique navale

Métallurgie

Science des matériaux

Technique du pétrole

Technique minière

Techniques sanitaires ef

municipales

Technologie hydrauliqu....... 0554

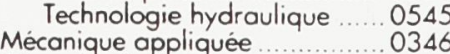

Matières plastiques

(Technologie)

Recherche operationnelle............ 0795

(Technologie) .....il............. 0795
Recherche operationnelle ......... 0796
Textiles et tissus (Technologie) 0794

\section{PSYCHOLOGIE}

\section{Généralites}

Personnalité

Psychobiologie

Psychologie clinique

0549

0538

0543

0544

0546

0552

0790

0547
0743

0794

0765

0551

0428

Psychologie du comportement

Psychologie du developpement

Psycholgie experimentale ...........

Pyy.ogie industrielle ............. 062

Psychologie physiologique ........ 0989

Psychologie sociale

0451 


\section{GENERAL ABSTRACT}

This dissertation has been divided into three separate chapters, each of which examines various aspects of the application of the strontium isotope $\left({ }^{87} \mathrm{Sr} / 86 \mathrm{Sr}\right)$ methodology as a paleoceanographic proxy for salinity change. Chapter 1 examines and conclusively dismisses vital effects associated with the uptake of ${ }^{87} \mathrm{Sr}$ and ${ }^{86} \mathrm{Sr}$ in marine bioprecipitates. Chapter 2 tests the application of Sr isotopes $\left({ }^{87} \mathrm{Sr} / 86 \mathrm{Sr}\right)$ as a paleosalinity proxy in a large restricted basin (the Pliocene of the Mediterranean) and Chapter 3 examines the use of a combined micropaleontological and strontium isotope methodology as a high resolution salinity proxy in coastal lagoon environments.

There exists an undocumented understanding among geochemists that there are no disequilibrium (vital) effects associated with the uptake of strontium isotopes in bioprecipitates. Data from Lee Stocking Island, Bahamas confirms and documents this hypothesis. The data set contains analyses of 40 samples derived from 37 different calcareous taxa inhabiting a wide range of carbonate subenvironments (i.e. reefal, intertidal, supratidal, mangrove). The precision of the analyses (mean $=0.709179 \pm 2.4 \mathrm{x}$ $10^{-5}(2 \sigma)$ ) was very close to the precision of the strontium isotope methodology confirming the homogeneity (at the present mass spectrometer resolution $\pm 2.0 \times 10^{-5}$ $(2 \sigma))$ of the ${ }^{87} \mathrm{Sr} / 86 \mathrm{Sr}$ isotopic composition of calcareous bioprecipitates.

Strontium isotope analysis $\left({ }^{87} \mathrm{Sr} / 86 \mathrm{Sr}\right.$ ) of foraminiferal calcite from marl/limestone couplets from the Trubi Fm in southern Italy (Precariti section) revealed a cyclical signal that could be attributed to precessionally controlled increases and decreases in precipitation during the early Pliocene of the Mediterranean. However, an attempt to replicate these results using samples from a different section (Monte Singa) was not successful. Detailed isotopic and geochemical analysis revealed subtle diagenetic contamination by altered coccoliths of the original results from the Precariti section.

The coccolith calcite was altered both in its trace element $(\mathrm{Sr} / \mathrm{Ca}, \mathrm{Mg} / \mathrm{Ca}, \mathrm{Fe} / \mathrm{Ca}$, $\mathrm{Mn} / \mathrm{Ca}, \mathrm{Na} / \mathrm{Ca}$ all were higher) and isotopic $\left({ }^{87} \mathrm{Sr} /{ }^{86} \mathrm{Sr}, \delta^{18} \mathrm{O}, \delta^{13} \mathrm{O}\right)$ composition from its original values. The coccolith ${ }^{87} \mathrm{Sr} / 86 \mathrm{Sr}$ values (limestones 0.709010 ; marls $0.7089512)$ were lower than Pliocene seawater $(0.70904-8)$ and similar to the ${ }^{87} \mathrm{Sr} / 86 \mathrm{Sr}$ values for Messinian evaporites (0.70885-95).

The foraminiferal calcite was unaltered and retained its trace elemental and isotopic composition. The original cyclical results from the Precariti section can be attributed to improper cleaning procedures which did not completely remove the coccolith calcite from the foraminifera before $\mathrm{Sr}$ isotopic analysis. In contrast, the Monte Singa samples were subjected to a more rigorous cleaning procedure (preleaching $0.01 \mathrm{~N} \mathrm{HCl}$ ) that removed the altered coccolith fraction.

Archaeological excavations within the inner harbor at Caesarea Maritima, Israel have been conducted to understand the history of the ancient harbor built by Herod the Great at the end of the 1st c. BC. An integrated foraminiferal and strontium isotope analysis $\left({ }^{87} \mathrm{Sr} /{ }^{86} \mathrm{Sr}\right.$ ) of three stratigraphic sections (Areas, I9, I14, TN1) from the inner harbor has greatly enhanced the archaeological interpretation. The foraminiferal analysis of forty-two sediment samples and forty-two ${ }^{87} \mathrm{Sr} /{ }^{86} \mathrm{Sr}$ measurements of six fossil taxa has indicated temporal paleosalinity changes that can be related to the form and function of the inner harbor. The recognition of three salinity controlled biofacies was based on the diversity and distribution of hyaline, agglutinated, and porcelaneous foraminiferal taxa.

This paleoenvironmental study using an integrated micropaleontological/strontium isotope approach emphasizes the potential of the methodology for the study of salinity changes in coastal lagoon environments. 


\section{ACKNOWLEDGEMENTS}

This research was partially funded by Natural Sciences and Engineering Research Council of Canada (NSERC) Operating Grant OGP0041665 to R. Timothy Patterson, and a NATO Collaborative Research Grant to R.T. P. and William Cavazza. It was also supported by personal NSERC postgraduate scholarships (PGSA, PGSB) and financial awards from Carleton University. I would like to thank R.T.P. for assisting me with my graduate studies and taking a keen interest in all my research ideas and projects. I would also like to thank John Blenkinsop who taught me the intricacies of mass spectrometer operation and Brian Cousens who came to my aid both in the laboratory and with the mass spectrometer.

On an international note, I am indebted to Avner Raban and staff members and volunteers of the Combined Caesarea Expeditions for their logistical support. Also, I thank Brian Yule for permission to use core samples from the inner harbour, and William Cavazza for assisting me with field work in southern Italy and for sharing his extensive knowledge of fine local Italian wines. I would also like to express my appreciation to all faculty members from the Ottawa-Carleton Geoscience Centre who took a personal interest in all my academic endeavours.

Finally, I thank my parents, Waldemar and Cheryl Reinhardt, who supported me in every way; my brother and sister and their spouses for their patience and understanding; and my wife, Heather, who provided editorial comments and suggestions that greatly improved the text as well as undying support and encouragement throughout my academic studies. 


\section{TABLE OF CONTENTS}

GENERAL ABSTRACT $\quad$................................. iii

ACKNOWLEDGEMENTS $\quad$................................... iv

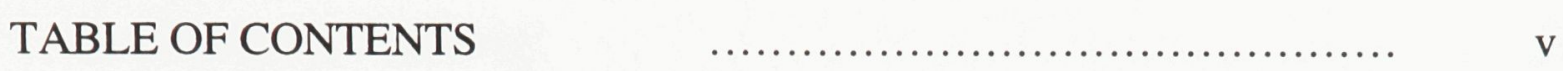

ORIGINAL CONTRIBUTION $\quad$................................. ix

LIST OF FIGURES $\quad$...................................

LIST OF TABLES

LIST OF PLATES $\quad$................................. xii

LIST OF APPENDICES

INTRODUCTION $\quad$................................ 1

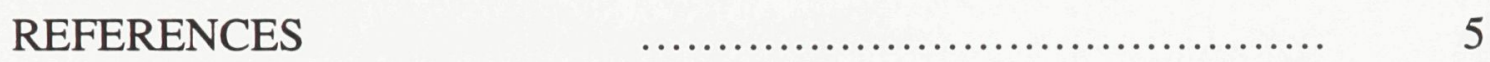

CHAPTER ONE

Testing for a Strontium Isotope 87Sr/86Sr Vital Effect: Negative Results from Modern Taxa found on Lee Stocking Island, Bahamas

ABSTRACT

INTRODUCTION

Oceanography $\quad \ldots \ldots \ldots \ldots \ldots \ldots \ldots \ldots \ldots \ldots . \ldots \ldots$

Sample Locations $\quad$..................... 11

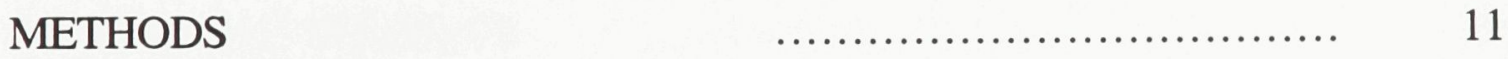

RESULTS AND DISCUSSION $\quad$............................ 13

Disequilibrium Effect $\quad \ldots \ldots \ldots \ldots \ldots \ldots \ldots \ldots \ldots \ldots$

${ }^{87} \mathrm{Sr} / 86_{\mathrm{Sr}}$ Composition of Modern Seawater $\quad \ldots \ldots \ldots \ldots \ldots . . . . .14$

CONCLUSIONS $\quad$............................ 15

ACKNOWLEDGEMENTS $\quad$........................... 15

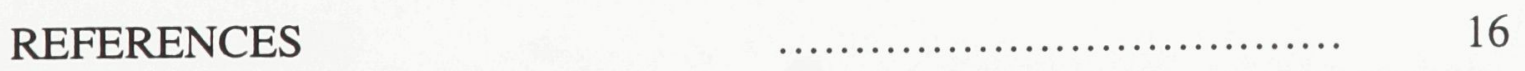

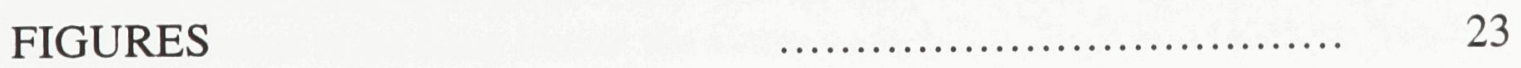

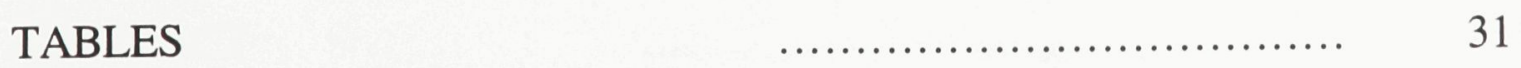


Testing the Application of Strontium Isotopes as a Paleosalinity Proxy:

Lithologically Controlled Diagenetic Results

ABSTRACT

INTRODUCTION

Background Geology

Previous Results

Precariti Section

$\underline{\text { Monte Singa Section }} \quad$................ 41

GEOCHEMICAL ANALYSES $\quad$............................. 43

GEOCHEMICAL RESULTS $\quad$............................ 44

Strontium Isotopic Ratios $\quad$............................ 44

Trace Element, $\mathrm{O}$ and $\mathrm{C}$ Isotopic Composition $\quad \ldots \ldots \ldots . . .45$

DISCUSSION $\quad$.................................. 48

Foraminifera Preservation $\quad$................................... 48

Coccolith Alteration $\quad$..................................... 51

Porewater Composition and Diagenetic Model $\quad$............... 55

Contamination of Original Precariti Results $\quad$................ 57

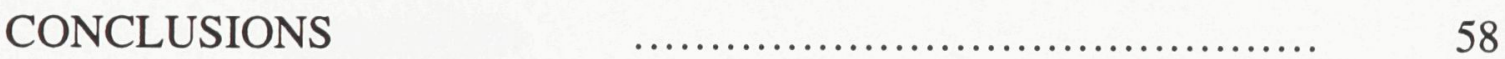

ACKNOWLEDGEMENTS $\quad$................................. 59

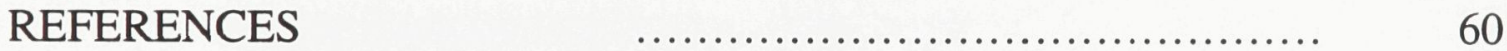

FIGURES

TABLES $\quad$................................ 89

PLATES $\quad$................................ 103

APPENDICES $\quad$................................ 107

CHAPTER THREE $\quad$......................................... 114 A Combined Micropaleontological/ Strontium Isotopic Methodology as a Paleosalinity Indicator: Evidence from King Herod the Great's Harbor, Caesarea Maritima, Israel. 
INTRODUCTION

Historical Context

Foraminifera

Strontium Isotope Research

METHODS

Micropaleontological Methods

Geochemical Methods

RESULTS

Sedimentology / Foraminifera

Biofacies 1

Lithology

Foraminifera

128

Biofacies 2

129

Lithology

129

Foraminifera

130

Biofacies 3

Lithology

Foraminifera

Strontium Isotopic Data

Mixing Equation and Source of Freshwater

132

Micropaleontological / Strontium Isotopic Paleoenvironmental Interpretation

DISCUSSION

CONCLUSIONS 


\section{PLATES}

175

APPENDICES

179

CONCLUSIONS

193 


\section{ORIGINAL CONTRIBUTION}

The following itemizes the extent of the contribution from other researchers to this doctoral dissertation. W. Cavazza from the Department of Mineralogical Sciences at the University of Bologna, Italy and R. Timothy Patterson collected the samples from the Precariti section in 1992. E.G. Reinhardt and W. Cavazza sampled the Monte Singa section in the fall of 1994. B. Yule (Museum of London Archaeological Services) collected the core samples from Area I14 in the inner harbour at Caesarea, Israel. Samples from Area I9 and Area TN1 were sampled by E.G. Reinhardt. C. Schröder-Adams and R.T. Patterson helped with the collection of samples from the Bahamas. The ICP-AES analysis was done by ARECO in Nepean, Ontario although sample preparation and digestion for this analysis was completed by E.G. Reinhardt. With the exception of assistance with field work, all sample preparation, SEM work, etc., was completed by E.G. Reinhardt in consultation with John Blenkinsop and R. Timothy Patterson.

With regard to co-authorship of the various papers (Chapters one to three), each paper was compiled and written by E.G. Reinhardt and submitted for comments to R.T. Patterson and John Blenkinsop. The final drafts are presented here, and encompass style and content edits as suggested by the other contributing authors. 
LIST OF FIGURES

Fig. 1-1. Location of Bahama Islands. 24

Fig. 1-2. Location of Lee Stocking Island and sample sites. 26

Fig. 1-3. Histogram and frequency distribution curve. 28

Fig. 1-4. Normal probability plot. 30

Fig. 2-1. Geological map of southern Italy. 74

Fig. 2-2. Stratigraphic section from the Precariti location. 76

Fig. 2-3. Stratigraphic section from the Monte Singa location. 78

Fig. 2-4. Bar graphs showing the distribution of ${ }^{87} \mathrm{Sr} / 86 \mathrm{Sr}$ values. $\quad 80$

Fig. 2-5. Bivariate plot of porewater and foraminifera ${ }^{87} \mathrm{Sr} /{ }^{86} \mathrm{Sr}$ values. $\quad 82$

Fig. 2-6. Bivariate plots of trace elements and isotopes. 84

Fig. 2-7. Bivariate plots of the trace element and ${ }^{87} \mathrm{Sr} /{ }^{86} \mathrm{Sr}$ values. 86

Fig. 2-8. Two-component mixing equation. - 88

Fig. 3-1. Location map of Caesarea and remains of ancient harbor. 152

Fig. 3-2. Archaeological reconstruction of Herod's harbor. 154

Fig. 3-3. Location of sample sites. 156

$\begin{array}{ll}\text { Fig. 3-4. Stratigraphic columns. } & 158\end{array}$

Fig. 3-5. Graphical representation of ${ }^{87} \mathrm{Sr} /{ }^{86} \mathrm{Sr}$ data. 160

Fig. 3-6. Mixing curves. 162

Fig. 3-7. Inner harbor phases. 164 


\section{LIST OF TABLES}

Table 1-1. Strontium isotope data. 32

Table 1-2. Distribution statistics and Chi-squared results. 34

Table 2-1. Strontium isotope data for the Monte Singa and Precariti sections. $\quad 90$

Table 2-2. Strontium isotope data $\left({ }^{87} \mathrm{Sr} / 86 \mathrm{Sr}\right)$ (marl and limestone). 92

Table 2-3. Strontium isotope data $\left({ }^{87} \mathrm{Sr} / 86 \mathrm{Sr}\right.$ ) (foraminifera and porewater). 94

Table 2-4. Trace element concentrations (foraminifera, coccoliths, terrigenous). 96

Table 2-5. Trace element concentrations (porewater). 98

Table 2-6. Ratios of trace elements and oxygen and carbon isotope data. $\quad 100$

Table 2-7. Compositional characters of the marl and limestone samples. 102

Table 3-1. Statistically Significant Foraminiferal abundances (Areas TN1and I9). 166

Table 3-2. Statistically Significant Foraminiferal abundances (Areas I14). 168

Table 3-3. Biofacies summary. $\quad 170$

Table 3-4. Strontium isotope data from the three Areas (TN1, I9, I14). 172

Table 3-5. Strontium isotope and concentration data of water sources. 174 


\section{LIST OF PLATES}

Plate 2-1. Specimens of altered coccoliths. 104

Plate 2-2. Specimens of coccoliths and foraminifera. 106

Plate 3-1. Common foraminiferal species. 176

Plate 3-2. Common foraminiferal species. 178 


\section{LIST OF APPENDICES}

$\begin{array}{lll}\text { Appendix 2-1 Strontium isotope analytical methods. } & 108\end{array}$

Appendix 2-2 Separatory and geochemical methods. 111

Appendix 3-1. Foraminiferal fauna reference list. 180

Appendix 3-2. Foraminiferal fractional abundances and uncertainties. 185 


\section{INTRODUCTION}

This dissertation has been divided into three separate chapters, each of which examines various aspects of the application of the strontium isotope $\left({ }^{87} \mathrm{Sr} / 86 \mathrm{Sr}\right)$ methodology as a paleoceanographic proxy for salinity change. Each chapter was written as a separate journal article for publication and all data were included in the individual papers with each containing a separate introduction and conclusion. Consequently, each chapter details the specific aspects of the particular study as a separate entity.

Strontium isotopes have been traditionally used as a chronostratigraphic tool for dating marine deposits with little research devoted to their potential use as a paleoceanographic indicator. Marine environments in close proximity to the fluvial sources of strontium input may have deviant ${ }^{87} \mathrm{Sr} / 86 \mathrm{Sr}$ ratios from that of normal seawater (0.70918). This deviation can be used to advantage for paleosalinity determinations in marginal marine or restricted basin environments. Previously, only limited research has been conducted to determine the use of strontium isotopes as a paleosalinity proxy and, to my knowledge, only one study from an estuarine environment has been published (Ingram and Sloan, 1992). This dissertation was designed to expand the existing body of knowledge regarding the use of $\mathrm{Sr}$ isotopes as a paleosalinity proxy in diverse environments. Consequently, one aspect of the dissertation applied $\mathrm{Sr}$ isotopes $\left({ }^{87} \mathrm{Sr} / 86 \mathrm{Sr}\right)$ as a paleosalinity proxy to a large restricted basin environment (the Pliocene of the Mediterranean) and, in contrast, also to the more restricted environment of a coastal lagoon (Israel). This contrast in environments was intended to highlight both the strengths and the weaknesses of using strontium isotopes $\left({ }^{87} \mathrm{Sr} / 86 \mathrm{Sr}\right)$ as a paleoceanographic tool and raise awareness of its potential uses.

This research is important because it further develops the strontium isotopic method as a paleoceanographic tool, thereby expanding its use beyond that of being used solely for chronostratigraphic determinations. The background research on the methodology has now reached the point where our understanding of the behaviour of strontium in the marine 
realm can lead to the development of new applications and areas of research. With increased applications and understanding, the use of strontium isotopes could become a very important paleosalinity tool for paleoceanographic and paleoclimatological studies. Currently, there are few reliable salinity proxies and it appears that the very strength of using strontium isotopes $\left({ }^{87} \mathrm{Sr} / 86 \mathrm{Sr}\right)$ as a paleosalinity tool may lie in its potential for accuracy and reliability.

An important corollary to the issue of using strontium isotopes $\left({ }^{87} \mathrm{Sr} / 86 \mathrm{Sr}\right)$ as a proxy is the issue of vital effects. Vital effects associated with strontium isotopes $\left({ }^{87} \mathrm{Sr}\right.$ and ${ }^{86} \mathrm{Sr}$ ) have not been examined in detail even though they could potentially have large repercussions for all aspects of strontium isotope research. The importance of this issue is that a vital effect could cause the ${ }^{87} \mathrm{Sr} /{ }^{86} \mathrm{Sr}$ values recorded in the biogenic precipitates to deviate from normal marine values. Although the issue of vital effects is crucial to the accurate use of strontium in paleoceanographic applications, critical analysis of published studies indicated that many researchers persist in dismissing a strontium isotope vital effect within marine bioprecipitates - even though no reliable research to determine a possible vital effect associated with strontium isotopes has been published. The limited studies regarding this issue do not provide the conclusive evidence required in order to disregard a strontium isotope vital effect. Therefore, rather than rely on previously published research, the vital effect study was designed to ensure that any deviation from normal marine water (if diagenesis could be ruled out) was due to freshwater dilution of seawater. The research in the Bahamas (Chapter 1) was intended to test for such a biological vital effect which could potentially discriminate between ${ }^{87} \mathrm{Sr}$ and ${ }^{86} \mathrm{Sr}$ in the uptake of strontium isotopes in the precipitation of skeletal calcite and aragonite from marine waters. The study was designed in such a way that it would, if successful, perhaps become the seminal paper upon which researchers could base their conclusions when evaluating the possible existence of vital effects. 
The analysis of the marl/limestone couplets of the Trubi fm (early Pliocene) of southern Italy (Chapter 2) was an attempt to test the use of the strontium isotopic method $\left({ }^{87} \mathrm{Sr} / 86 \mathrm{Sr}\right)$ in a large restricted basin setting. Previous high resolution strontium isotopic studies conducted by researchers elsewhere had proven initially to be very promising. The results of their studies indicated that the open ocean ${ }^{87} \mathrm{Sr} /{ }^{86} \mathrm{Sr}$ record varied with Milankovitch cyclicity as a result of short term climatic changes of $10^{3}-10^{4}$ years (Dia et al., 1992; Clemens et al., 1993). However, attempts to replicate this variation were unsuccessful (Clemens et al., 1995; Henderson et al., 1993). To further test the utility of the high resolution technique used to discriminate subtle paleoceanographic changes a more highly restricted setting (i.e. Mediterranean) was chosen where any strontium isotopic changes would tend to be maximized (Richter and Turekian, 1993). The effect of the input of strontium from riverine sources that would have had deviant ${ }^{87} \mathrm{Sr} / 86 \mathrm{Sr}$ values from that of Pliocene seawater would be maximized in the restricted basin setting of the Mediterranean. Previous research indicated the marl/limestone couplets of the Trubi $\mathrm{fm}$ may have been formed by precessionally controlled changes in precipitation. The formation of the marls was attributed to pluvial periods with increased riverine input, while dryer periods led to limestone deposition. By analyzing the ${ }^{87} \mathrm{Sr} /{ }^{86} \mathrm{Sr}$ composition of the marl/limestone couplets in the Trubi fm the strontium isotopic method was tested as a paleosalinity proxy in the large restricted basin setting of the Mediterranean. This research was intended to demonstrate the use of strontium isotopes as a paleooclimatic tool in restricted basin settings, and to add new information to the interpretation of the origin of the cyclical sedimentation of the Trubi fm.

The study from the ancient harbor at Caesarea Maritima, Israel (Chapter 3) was conducted in order to test the strontium isotope $\left({ }^{87} \mathrm{Sr} / 86 \mathrm{Sr}\right)$ methodology in a restricted coastal lagoon type setting. This enabled a comparison of the validity and usefulness of this methodology between the highly restricted coastal lagoon environment of Caesarea Maritima with the relatively open conditions of the Mediterranean (Trubi fm). The 
restricted lagoonal environment not only ensured a contrast to that of the Mediterranean, but it also provided an ideal environment to compare the Sr methodology with initial micropaleontological results which indicated salinity changes over the life of the harbor. The accuracy and extent of the micropaleontological data provided a sound control for salinity and allowed the $\mathrm{Sr}$ isotopic method to be tested as a high resolution paleosalinity indicator in a restricted coastal setting. This research is important since salinity changes within restricted coastal lagoon settings can be linked to paleoclimatic changes in precipitation. It was also anticipated that the strontium isotope $\left({ }^{87} \mathrm{Sr} / 86 \mathrm{Sr}\right)$ methodology could provide more detailed indications of salinity changes than micropaleontological methods alone. Finally, an additional benefit to this application was that it would not only test the strontium isotope $\left({ }^{87} \mathrm{Sr} /{ }^{86} \mathrm{Sr}\right)$ method, but it would also add information to the archaeological interpretation of the ancient harbor.

This dissertation endeavours to provide future researchers with a more advanced and comprehensive understanding of the potential uses of strontium isotope $\left({ }^{87} \mathrm{Sr} / 86 \mathrm{Sr}\right)$ methodology and some of the research issues which are associated with its use. The three detailed studies within the dissertation ensured that aspects of the application of the $\mathrm{Sr}$ methodology, specifically the application to a restricted lagoonal setting and a marginal marine environment, received a detailed and focused examination. Additionally, it also endeavours to provide researchers with a conclusive and reliable study regarding the issue of strontium isotope vital effects. The intended result of these studies is to not only expand the horizons of knowledge regarding the use of strontium isotope $\left({ }^{87} \mathrm{Sr} / 86 \mathrm{Sr}\right)$ methodology and associated effects, but also to provide colleagues with conclusive research which may provide a basis for future studies. 


\section{REFERENCES}

Clemens S.C., Farrell J.W., and Gromet L.P. (1993) Synchronous changes in seawater strontium isotope composition and global climate. Nature 363, 607.

Clemens S.C., Gromet L.P., and Farrell J.W. (1995) Artefacts in Sr isotope records. Nature 373, 201.

Dia A.N., Cohen A.S., O'Nions R.K., and Shackleton N.L. (1992) Seawater Sr isotope variation over the past $300 \mathrm{Kyr}$ and the influence of global climate cycles. Nature (London), 356, 786-788.

Henderson G.M., O’Nions R.K., and Shackleton N.L. (1993) Sr-isotopes in Quaternary planktonic foraminifera from the Pacific and Indian Oceans. EOS, Abrst. Spring Mtng., 176.

Ingram B.L. and Sloan D. (1992) Strontium isotopic composition of estuaring sediments as paleosalinity-paleoclimate indicator. Science 255, 68-72.

Richter F.M. and Turekian K.K. (1993) Simple models for the geochemical response of the ocean to climatic and tectonic forcing. Earth Planet. Sci. Lett. 119, 121-131. 
CHAPTER 1. Testing for a Strontium Isotope $\left({ }^{87} \mathrm{Sr} /{ }^{86} \mathrm{Sr}\right)$ Vital Effect: A Negative Response from Modern Taxa found on Lee Stocking Island, Bahamas.

\section{ABSTRACT}

There exists an undocumented understanding among geochemists that there are no isotopic fractionation (vital) effects associated with the uptake of strontium isotopes (87Sr and $86 \mathrm{Sr}$ ) in bioprecipitates. Data from Lee Stocking Island, Bahamas confirms and documents this hypothesis. Our data set contains analyses of 40 samples derived from 37 different calcareous taxa inhabiting a wide range of carbonate subenvironments (i.e. reefal, intertidal, supratidal, mangrove). The precision (std deviation) of our analyses (mean = $\left.0.709179 \pm 2.4 \times 10^{-5}(2 \sigma)\right)$ was very close to the precision of the strontium isotope methodology confirming the homogeneity (at the present mass spectrometer resolution of \pm $\left.2.0 \times 10^{-5}(2 \sigma)\right)$ of the ${ }^{87} \mathrm{Sr} / 86 \mathrm{Sr}$ isotopic composition of calcareous bioprecipitates.

Since our data confirmed the lack of a disequilibrium effect, our forty strontium isotopic analyses additionally provide a precise estimate of the modern ${ }^{87} \mathrm{Sr} / 86 \mathrm{Sr}$ composition of seawater. Our estimate at $0.709179 \pm 2.4 \times 10^{-5}(2 \sigma)$ is slightly higher than previously published values for the ${ }^{87} \mathrm{Sr} / 86 \mathrm{Sr}$ composition of modern seawater which cluster around 0.709175 although they are similar considering analytical uncertainty. We suggest, based on the excellent analytical characters of our sample set, that our ${ }^{87} \mathrm{Sr} / 86 \mathrm{Sr}$ value for mean seawater is a precise estimate. 


\section{INTRODUCTION}

The ${ }^{87} \mathrm{Sr} /{ }^{86} \mathrm{Sr}$ isotopic ratio of $\mathrm{Sr}$ in marine deposits has received increased attention by earth science researchers in recent years as a chronostratigraphic tool (Burke et al., 1982; DePaolo and Ingram, 1985; Depaolo, 1986; Hess et al., 1986, 1989; Miller et al., 1988, 1991; Hodell, 1991; Hodell et al., 1989, 1990; McArthur et al., 1992, 1993a,b, 1994; Paytan et al., 1993; Oslick et al. 1994; Patterson et al., 1995; Farrell et al., 1995; and many others). The ${ }^{87} \mathrm{Sr} /{ }^{86} \mathrm{Sr}$ ratio of the world's oceans has varied over geologic time allowing the development of a temporal calibration curve for dating marine deposits in the Phanerozoic. The utility of the methodology depends upon four major factors. First, the methodology requires that the ${ }^{87} \mathrm{Sr} /{ }^{86} \mathrm{Sr}$ ratio be homogeneous throughout the world's oceans. This phenomenon holds true except in environments such as those in close proximity to rivers, or to sources of hydrothermal fluids (Ingram and Sloan, 1992; Bryant et al., 1995; Pichler and Dix, 1996). The homogeneity of the ${ }^{87} \mathrm{Sr} /{ }^{86} \mathrm{Sr}$ signal is attributed to the residence time of strontium being much longer than the mixing time of the world's oceans (residence time 2-3 Myrs; mixing time approx. 1500 yrs: Broecker and Peng, 1982; Hodell et al., 1990; Paytan et al., 1993). Secondly, the rate of ${ }^{87} \mathrm{Sr} / 86 \mathrm{Sr}$ change through time must be rapid enough to allow chronostratigraphic determinations. This is generally true, with observed maxima and minima in the temporal evolution of the ${ }^{87} \mathrm{Sr} /{ }^{86} \mathrm{Sr}$ signal during the Phanerozoic (Burke et al., 1982; Koepnick et al., 1985; McArthur, 1994). This temporal variation of the oceanic strontium isotopic signal has been attributed generally to varying fluxes from hydrothermal sources at mid-ocean ridges and continental weathering via rivers (Hodell et al., 1990; Edmond, 1992; McArthur, 1994; Bryant et al., 1995;

Harris, 1995; and many others). Thirdly, the material used to measure a strontium isotope ratios should be diagenetically unaltered. Research has indicated that some materials are more stable than others and are thus more suitable for use in dating material. Examples of stable marine materials successfully used for ${ }^{87} \mathrm{Sr} /{ }^{86} \mathrm{Sr}$ determinations include phosphates, barites, chemical, and biogenic precipitates (Popp et al., 1986; Hess et al., 1986; Miller et 
al., 1988; Hodell, 1991; Hodell et al. 1989, 1990; Carpenter et al., 1991; Bertram et al., 1992; Paytan et al., 1993; Stille et al., 1994; McArthur et al., 1994, 1990; Farrell et al., 1995; and many others - see McArthur (1994) for a full discussion). Finally (four), the methodology depends heavily upon the requirement (particularly with biogenic precipitates) that there are no disequilibrium, or vital effects associated with the uptake of strontium from seawater (Bryant et al., 1995).

Vital effect, or nonequilibrium precipitation, is a physiologically mediated variation in the elemental or isotopic composition of a skeleton compared to inorganic carbonate formed under the same environment (Dodd and Stanton, 1990). Oxygen and carbon isotope vital effects associated with various taxa are widely known and have been attributed to kinetic effects in rapidly calcifying organisms, and to metabolic effects arising from photosynthesis and respiration (Grossman, 1987; McConnaughey, 1989a,b; Dodd and Stanton, 1990; Spero et al., 1991). There are also known differences in the elemental composition and concentration of trace elements (i.e. $\mathrm{Mg}, \mathrm{Sr}, \mathrm{Na}$ etc.) between and within various organisms independent of environment (Bender et al., 1975; Veizer, 1983; Delaney et al., 1985; Dodd and Stanton,1990; Nüremberg et al., 1996). When considering potential disequilibrium effects with strontium isotopes, one might argue that the atomic weight difference between ${ }^{86} \mathrm{Sr}$ and ${ }^{87} \mathrm{Sr}$ (approx. $1 \%$ ) is not large enough to be effectively fractionated kinetically in the way that occurs with the isotopes of oxygen $(16 \mathrm{O}$ and ${ }^{18} \mathrm{O}$; approx. $\left.11 \%\right)$ and carbon $\left({ }^{12} \mathrm{C}\right.$ and ${ }^{13} \mathrm{C}$; approx. $\left.8 \%\right)$. Additionally, strontium cannot be metabolized although it may be incorporated by various taxa in a chemically complexed form, possibly explaining the strontium enrichment observed in planktic foraminifera (Bender et al., 1975). However, the complexing of strontium would result in a larger overall molecular weight and a reduction in the relative mass difference among the isotopes of strontium. This would result in a reduced potential for biological or kinetic fractionation between the isotopes of strontium. 
Although some of the mechanisms of biologically mediated disequilibrium effects are generally well understood there still exist many unknown factors. An example is high magnesium barnacle calcite, which shows ${ }^{18} \mathrm{O}$ enrichment compared to inorganic calcite equilibrium that cannot be explained by kinetic or metabolic effects. If this enrichment is not caused by factors such as mineralogical changes or $\mathrm{Mg}^{2+}$ content then it could represent another class of disequilibrium effect (Killingley and Newman, 1983; McConnaughey, 1989a). It is evident that vital effects are still not completely understood and to our knowledge no one has systematically tested or published any results which conclusively dismiss a strontium isotope vital effect, even though the strontium isotopic composition of organic carbonate is used increasingly as a chronostratigraphic tool. However, vital effects have often been disregarded by researchers based on limited and scattered data (Veizer, 1983; Schmitz et al., 1991; Bryant et al., 1995). Unfortunately, these limited studies do not provide the conclusive evidence required in order to dismiss strontium isotope vital effects within marine bioprecipitates.

In a previous study (Patterson et al., 1995; unpublished data) highly variable ${ }^{87} \mathrm{Sr} /{ }^{86} \mathrm{Sr}$ values from various Neogene taxa from Italy (eg. planktic foraminifera, echinoderms) were found that could not be definitively ascribed to diagenetic alteration or riverine influence. Since there was no published data, we questioned whether the observed deviations in the ${ }^{87} \mathrm{Sr} / 8{ }^{8} \mathrm{Sr}$ ratios could possibly be due to vital effects.

To satisfy these queries, and to assess conclusively the impact of any strontium isotope vital effects this study analyzed the ${ }^{87} \mathrm{Sr} /{ }^{86} \mathrm{Sr}$ composition of 37 different modern calcareous and aragonitic (invertebrate and algae) taxa from a wide variety of environments from Lee Stocking Island, Bahamas (Figs. 1-1 and 1-2). This locality was selected for several reasons: 1) it is not influenced by continental runoff that may potentially alter the ${ }^{87} \mathrm{Sr} / 86 \mathrm{Sr}$ signal; 2) it is a shallow environment represented by a wide variety of subenvironments, thus permitting the sampling of a great number of taxa; and 3) seawater in this locality is well mixed and openly circulated with marine waters. To eliminate any 
diagenetic effect only modern living, or recently expired, specimens of the various taxa were selected. Therefore any observed systematic variation in the strontium isotopic signal should be due exclusively to a vital effect.

In addition, if our results proved the nonexistence of a vital effect, our sample set $(n=40)$ from Lee Stocking Island would provide a very high precision ${ }^{87} \mathrm{Sr} / 86 \mathrm{Sr}$ estimate for modern seawater.

\section{Oceanography}

Lee Stocking Island, part of the Exuma chain of Islands in the Bahamas, is characterized by a variety of carbonate subenvironments ranging from mangrove lagoons to deep water reefal systems (Figs. 1-1 and 1-2). Lee Stocking Island is also situated on the eastern margin of the Great Bahama Bank where wave, tidal, and oceanographic patterns result in a freely circulated environment with open marine waters from the Atlantic Ocean.

The open waters of Exuma Sound provide a large fetch distance for wave development, and the Sound is subject to trade winds from the east and the southeast. As a result, the seaward side of Lee Stocking Island is subject to high energy waves. In addition, the bank margins themselves are greatly affected by tidal flow and large scale oceanographic patterns (Fig. 1-1; Kendall et al., 1988; Dill et al., 1989).

Reversing tidal currents bring together the relatively cool oceanic waters from Exuma Sound and the more saline and warmer waters from the bank itself. Flood tides bring oceanic waters from Exuma Sound on to the Great Bahama Bank's eastern margin, and ebb tides and wind-driven circulation return warm and more saline waters formed by solar heating and evaporation on the shallow bank back to the margin (Fig. 1-1; Kendall et al., 1988; Dill et al., 1989).

The maximum tidal range is $1 \mathrm{~m}$ but sea level can vary as a result of the intensity, direction and duration of the winds over the shallow bank. During large tropical storms and hurricanes, low barometric pressure also raises sea level, creating a storm surge that 
increases current velocities over shoal areas of the bank (Fig. 1-1; Kendall et al., 1988; Dill et al., 1989).

Upwelling occurs when winds move surface waters away from the bank margins bringing colder and nutrient-rich deep water up onto the shallow bank. During the summer months, when lower velocity winds prevail, the relatively warm but dense saline waters formed on the bank flow towards the margins as underflows and spill into the Exuma Sound as falling currents (Fig. 1-1; Kendall et al., 1988; Dill et al., 1989).

\section{Sample Locations}

Sample locations were selected from environments on the windward and leeward sides of the island (Fig. 1-2). All subenvironments were sampled including intertidal, supratidal, shallow, and deep reefal hard and soft grounds. Sample localities as labelled in Fig. 1-2 are: 1) Acropora palmata fringing reef windward side of Lee Stocking Island in approximately $2 \mathrm{~m}$ water depth (soft and hard grounds); 2) Thalassia grass beds near Acropora palmata reef on windward side of the island in approximately $3 \mathrm{~m}$ water depth; 3 ) intertidal and subaerial hardground on windward side of Lee Stocking Island near the airstrip; 4) mangrove environment, fluctuating from hypersaline conditions during the dry season to hyposaline during the wet (15 cm water depth); 5) Dune Pass Bay, a shallow (1$2 \mathrm{~m}$ water depth) cove on the leeward side of the island; 6) subtidal hardground (1-2m) environment on the opposing windward side of Lee Stocking Island; 7) reef system at approximately $20 \mathrm{~m}$ water depth growing on a Pleistocene cliff face (Perry Reef).

\section{METHODS}

Samples were collected from the various subenvironments found around Lee Stocking Island (Fig. 1-2; Table 1-1). Wherever possible, live organisms were collected. However, several of the infaunal species required collection of recently dead specimens. In this category, only specimens in pristine condition were selected (i.e. articulated bivalves). 
The live specimens were cleaned using standard malacological and micropaleontological techniques. Bivalve and gastropod specimens were briefly boiled and any living tissue was removed with forceps and probes. Similarly, living tissue from coral and calcareous algae was removed by immersing the samples in a bleach bath for several hours. Sediment samples containing micropaleontological specimens were washed through a 63 micron sieve and allowed to dry before specimens were selected for analysis. Samples for chemical analysis were taken from the interior portion of the skeletal material in order to prevent any contamination from other encrusting or boring organisms. Samples of individual foraminiferal tests were hand picked from the surficial sediment samples. Only taphonomically pristine specimens were selected (no abrasion, boring, or fragmentation).

Samples were subjected to a rigorous cleaning procedure that used a strong $\mathrm{HCl}$ (1.0 $\mathrm{N}$ for the macroorganisms and $0.5 \mathrm{~N}$ for the microorganisms) to etch and remove the outer portion of the skeletal material, and then washed in an ultrasonic bath of pure water. Samples were then dissolved in $2.5 \mathrm{~N} \mathrm{HCl}$ as they were very clean with no contaminating siliciclastic fraction that may contain radiogenic strontium (see McArthur, 1994). Only an organic residue was present after dissolution.

Strontium and calcium were separated from the samples by using ion-exchange columns of Bio-Rad AG50 X-8 resin with $2.5 \mathrm{~N} \mathrm{HCl}$ as the eluting agent. The strontium was separated from calcium by using a second column of Teflon powder coated with bis (2-ethylhexyl) phosphoric acid (HDEHP), with $0.01 \mathrm{~N} \mathrm{HCl}$ as the eluting agent.

The isotopic compositions of the 40 samples were measured on a Finnigan-MAT 261 multicollector thermal ionization mass spectrometer operated in static mode. Ten replicate analyses of the SRM 987 standard gave a mean ${ }^{87} \mathrm{Sr} / 86 \mathrm{Sr}$ value of $0.710250 \pm$ $2.6 \times 10^{-5}(2 \sigma)$ and our blank value was 369 picograms (Table 1-2). Mass spectrometer analysis included 10 blocks of 10 integrations giving 100 measured ratios for each of the 40 samples (Table 1-1). No outliers were discarded from the data sets and all sample values were included in the study to prevent any biasing of the data. 


\section{RESULTS AND DISCUSSION}

\section{Disequilibrium Effect}

Our analyses of 37 different taxa recovered from seven carbonate subenvironments (i.e. reef, intertidal, supratidal etc.) do not indicate the existence of any strontium disequilibrium (vital) effect (Table 1-1). All samples had ${ }^{87} \mathrm{Sr} / 86 \mathrm{Sr}$ values that were clustered within analytical uncertainty of the mass spectrometer making any possible vital effect indistinguishable from the analysis statistics.

All individual analyses had in-run statistics (internal precision) with standard deviations within $\pm 2.0 \times 10^{-5}(2 \sigma)$, and 16 of the 40 samples were within $\pm 1.0 \times 10^{-5}$ ( $2 \sigma$; Table 1-1). All individual analyses were, therefore, well within the $\pm 2.0 \times 10^{-5}$ external precision widely reported on the SRM 987 standard at the $95 \%$ confidence interval and were considered good determinations. Our measurement of the SRM 987 standard over the period of analysis yielded a mean value of $0.710250 \pm 2.6 \times 10^{-5}$, which is consistent with the values reported elsewhere (compilation of values by McArthur, 1994; $0.710248 \pm 2.0 \times 10^{-5}(2 \sigma)$; Table 1-2).

Our set of forty analyses displayed no aberrant strontium isotopic ratios and there was no consistent departure from the ${ }^{87} \mathrm{Sr} /{ }^{86} \mathrm{Sr}$ composition of mean seawater $(0.709175)$ as compiled from various studies and summarized by McArthur (1994). The mean value of our determinations was 0.709179 with an uncertainty of $\pm 2.4 \times 10^{-5}$ at the $95 \%$ confidence interval (Table 1-2). The spread of our individual ${ }^{87} \mathrm{Sr} / 86 \mathrm{Sr}$ values was just outside the resolution of the mass spectrometer based on the repeated analysis of the SRM 987 standard $\left( \pm 2.0 \times 10^{-5}\right)$, indicating that all the samples were analytically homogeneous and there was no resolvable disequilibrium effect.

The frequency distribution of the forty analyses also indicates that there was no disequilibrium effect, as none of the taxa showed any systematic departure from the mean ${ }^{87} \mathrm{Sr} /{ }^{86} \mathrm{Sr}$ value for modern seawater (Fig. 1-3). The frequency distribution of the forty 
analyses was slightly negatively skewed (mean 0.709179; median 0.709183 ; mode 0.709185; Table 1-2). However, the normal probability plot indicates a relatively normal distribution and a Chi-Squared test indicates that at the $10 \%$ significance level the sample values are normally distributed (Fig. 1-4; Table 1-2). Thus, the variation exhibited by the strontium isotope analyses is random.

\section{${ }^{87} \mathrm{Sr} /{ }^{86} \mathrm{Sr}$ Composition of Modern Seawater}

Since there are no observable disequilibrium effects associated with any of the sampled taxa at Lee Stocking Island, the forty analyses provide a high precision estimate of modern seawater (Table 1-2). Our estimate of mean ${ }^{87} \mathrm{Sr} / 86 \mathrm{Sr}$ seawater at 0.709179 is precise for the following reasons: 1) our estimate is based on a large number of samples $(\mathrm{n}=40)$ of a high precision $\left( \pm 2.4 \times 10^{-5}(2 \sigma)\right) ; 2$ ) our ${ }^{87} \mathrm{Sr} / 86 \mathrm{Sr}$ values are normally distributed suggesting that the spread of values is due to random analytical errors affecting the precision and not systematic errors which might produce an other than normal distribution (Table 1-2; Figs. 3 and 4); 3) the measurement of SRM 987 at $0.710250 \pm 2.6$ $x 10^{-5}(2 \sigma)$ is very close to the longterm average reported value of $0.710248 \pm 2.0 \times 10^{-5}$ and our $\Delta^{87} \mathrm{Sr}$ value $\left({ }^{87} \mathrm{Sr} /{ }^{86} \mathrm{Sr}_{\text {sample }}{ }^{-87} \mathrm{Sr} /{ }^{86} \mathrm{SrSRM} 987\right)$ at $-1071 \times 10^{-6}$, is consistent with longterm values from a variety of studies as reported in McArthur (1994), suggesting that our value for mean seawater is not affected by a constant bias in the measurements (McArthur, 1994; Table 1-2); 4) all samples were derived from a well circulated marine environment far removed from any waters of continental influence; and 5) only living or recently dead specimens were used, eliminating any possible diagenetic effect.

Our estimate is slightly higher than the values for the ${ }^{87} \mathrm{Sr} / 86 \mathrm{Sr}$ composition of modern seawater which have clustered around 0.709175 from recently reported analyses (see McArthur, 1994). However, the collection of ${ }^{87} \mathrm{Sr} / 86 \mathrm{Sr}$ values for seawater reported in McArthur (1994) is from a number of laboratories, and may suffer from interlaboratory 
biases, differences in sample preparation, mass spectrometer techniques and data presentation (see McArthur, 1994 for a full discussion). We suggest that based on the characters of our sample set, our results are a very good estimate of the ${ }^{87} \mathrm{Sr} / 86 \mathrm{Sr}$ value for mean seawater $\left(0.709179\right.$ with a standard error of $\pm 2 \times 10^{-6}$ and a $\Delta^{87} \mathrm{Sr}$ of $-1071 \times 10^{-6}$; Table 1-2).

\section{CONCLUSIONS}

At the present resolution of the strontium isotope methodology, no disequilibrium effect was distinguishable from 40 samples of 37 calcareous taxa obtained from a wide range of marine environments from Lee Stocking Island, Bahamas. Since no disequilibrium effect was determined, and since the frequency distribution of the 40 analyses was normally distributed, our mean strontium isotope value of $0.709179 \pm 2.4 \mathrm{x}$ $10^{-5}(2 \sigma)$ is a very good estimate of the ${ }^{87} \mathrm{Sr} /{ }^{86} \mathrm{Sr}$ composition of modern seawater.

\section{ACKNOWLEDGEMENTS}

Research was partially supported by Natural Sciences and Engineering Council of Canada Research Grant to RTP (OGP0041665) and research funds provided by J.B. We would like to thank Dr. C. Schröder-Adams who provided travel support for fieldwork in the Bahamas through a Carleton University GR5 grant. We would also like to thank both H.C. Devine and H.E. Anderson for critically reviewing the manuscript and improving the text. 


\section{REFERENCES}

Bender M. L., Lorens R.B., and Williams D.F. (1975) Sodium, magnesium and strontium in the test of planktic foraminifera. Micropaleontol. 21, 448-459.

Bertram C.J., Elderfield H., Aldridge R.J., and Conway Morris S. (1992) ${ }^{87} \mathrm{Sr} / 86 \mathrm{Sr}$, ${ }^{143} \mathrm{Nd} /{ }^{144} \mathrm{Nd}$ and REEs in Silurian phosphatic fossils. Earth Planet. Sci. Lett. 113, 239-249.

Broecker W.S. and Peng T.H. (1982) Tracers in the Sea. Lamont-Doherty Geological Observatory.

Bryant J.D., Jones D.S., and Mueller P.A. (1995) Influence of freshwater flux on ${ }^{87} \mathrm{Sr} / 86 \mathrm{Sr}$ chronostratigraphy in marginal marine environments and dating of vertebrate and invertebrate faunas. J. Paleont. 69, 1-6.

Burke W.H., Denison R.E., Hetherington E.A., Koepnick R.B., Nelson H.F., and Otto J.B. (1982) Variation of ${ }^{87} \mathrm{Sr} / 86 \mathrm{Sr}$ throughout Phanerozoic time. Geology 10, 516519.

Carpenter S.J., Lohmann K.C., Holden P., Walter L.M., Huston T.J., and Haliday A.N. (1991) $\delta^{18} \mathrm{O}$ values, ${ }^{87} \mathrm{Sr} /{ }^{86} \mathrm{Sr}$ and $\mathrm{Sr} / \mathrm{Mg}$ ratios of Late Devonian abiotic calcite: Implications for the composition of ancient seawater. Geochim. Cosmochem. Acta 55, 1991-2010. 
Delaney M.L., Be A.W.H., and Boyle E.A. (1985) Li, Sr, Mg, Na in foraminiferal calcite shells from laboratory culture, sediment traps, and sediment cores. Geochim. Cosmochim. Acta 49, 1327-1341.

DePaolo D.J. (1986) Detailed record of the Neogene Sr isotopic evolution of seawater from DSDP Site 590B. Geology 14, 103-106.

DePaolo D.J. and Ingram B. (1985) High resolution stratigraphy and strontium isotopes. Science 227, 938-941.

Dill R.F., Kendall C.G.St.C., and Shinn E.A. (1989) IGC Field Trip T373: Giant subtidal stromatolites and related sedimentary features, Lee Stocking Island, Exumas, Bahamas. American Geophysical Union.

Dodd J.R. and Stanton R.J. (1990) Paleoecology Concepts and Applications. John Wiley and Sons.

Edmond J.M. (1992) Himalayan tectonics, weathering processes, and the strontium isotope record in marine limestones. Science 258, 1594-1597.

Farrell J.W., Clemens S.C., and Gromet L.P. (1995) Improved chronostratigraphic reference curve of late Neogene seawater. Geology 23, 403-406.

Grossman E.L. (1987) Stable isotopes in modern benthic foraminifera: a study of vital effect. J. Foram. Res. 17, 48-61. 
Harris N. (1995) Significance of weathering Himalayan metasedimentary rocks and leucogranites for the $\mathrm{Sr}$ isotope evolution of seawater during the early Miocene. Geology 23, 795-798.

Hess J., Bender M.L., and Schilling J.G. (1986) Evolution of the ratio of strontium-87 to strontium-86 in seawater from Cretaceous to Present. Science 231, 979-984.

Hess J., Stott L.D., Bender M.L., Kennet J.P., and Schilling J.G. (1989) The Oligocene marine microfossil record: age assessments using strontium. Paleoceanography $\mathbf{4}$, 655-679.

Hodell D.A. (1991) Variations in the strontium isotopic composition of seawater during the Neogene. Geology. 19, 24-27.

Hodell D.A., Mueller P.A., McKenzie J.A., and Mead G.A. (1989) Strontium isotope stratigraphy and geochemistry of the Late Neogene ocean. Earth Planet. Sci. Lett. 92, $165-178$.

Hodell D.A., Mead G.A., and Mueller P.A. (1990) Variation in the strontium isotopic composition of seawater ( $8 \mathrm{Ma}$ to present): implications for chemical weathering rates and dissolved fluxes to the oceans. Chem. Geol. 80, 291-307.

Ingram B.L.and Sloan D. (1992) Strontium isotopic composition of estuarine sediments as paleosalinity-paleoclimate indicator. Science $\mathbf{2 5 5}$, 68-72. 
Kendall C.G.St.C., Dill R.F., and Shinn E.A. (1988) Guidebook of the marine geology and tropical environments of the southern Exuma Islands and Cays, Bahamas. Special Publication of the Caribean Marine Research Center and the Department of Geology, University of South Carolina.

Killingley J. S. and Newman W.A. (1983) ${ }^{18} \mathrm{O}$ fractionation in barnacle calcite. A barnacle paleotemperature equation. J. Mar. Res. 40, 893-902.

Koepnick R.B., Burke W.H., Denison R.E., Hetherington E.A., Nelson H.F., Otto J.B., and Waite L.E. (1985) Construction of the seawater ${ }^{87} \mathrm{Sr} /{ }^{86} \mathrm{Sr}$ curve for the Cenozoic and Cretaceous: supporting data. Chem. Geol. 58, 55-81.

McArthur J.M. (1994) Recent trends in strontium isotope stratigraphy. Terra Nova 6, 331-358.

McArthur J.M., Sahami A.R., Thirlwall M.F., Osborn A.O., and Hamilton P.J. (1990) Dating phosphogenesis with Sr isotopes. Geochim. Cosmochim. Acta 54, 13431351.

McArthur J.M., Kennedy W.J., Gale A.S., Thirlwall M.F., Chen M., Burnett J.A., and Hancock J.M. (1992) Strontium-isotope stratigraphy in the Late Cretaceous: intercontinental correlation of the Campanian/Maastrichtian boundary. Terra Nova 4, 385-393 
McArthur J.M., Thirlwall M.F., Gale A.S., Kennedy W.J., Burnett J.A., Mattey D., and Lord A.R. (1993a) Strontium-isotope stratigraphy for the Late Cretaceous: a new curve, based on the English Chalk. In High Resolution Stratigraphy (ed. E.Hailwood and R.Kid). Spec. Publ. Geol. Soc. London 70, 195-209.

McArthur J.M., Gale A.S., Thirlwall M.F., and Kennedy W.J. (1993b) Strontium-isotope stratigraphy for the Late Cretaceous: age models and intercontinental correlations for the Campanian. Paleoceanography 8, 859-873.

McArthur J.M., Kennedy W.J. Chen M., Thirlwall M.F., and Gale A.S. (1994) Strontium isotope stratigraphy for the Late Cretaceous: direct numerical age calibration of the Srisotope curve for the U.S. Western Interior Seaway. Palaeogeogr. Palaeoclim. Palaeoecol. 108, 95-119.

McConnaughey T. (1989a) ${ }^{13} \mathrm{C}$ and ${ }^{18} \mathrm{O}$ isotopic disequilibrium in biological carbonates: I. Patterns. Geochim. Cosmochim. Acta 53, 151-162.

McConnaughey T. (1989b) ${ }^{13} \mathrm{C}$ and ${ }^{18} \mathrm{O}$ isotopic disequilibrium in biological carbonates: II. In vitro simulation of kinetic isotope effects. Geochim. Cosmochim. Acta 53, 163-171.

Miller K.G., Feigenson M.D., Kent D.V., and Oleson R.K. (1988) Upper Eocene to Oligocene isotope $\left({ }^{87} \mathrm{Sr} /{ }^{86} \mathrm{Sr}, \delta{ }^{18} \mathrm{O}, \delta^{13} \mathrm{C}\right)$ standard section, Deep Sea Drilling Project Site 522. Paleoceanography 3, 223-233. 
Miller K.G., Feigenson M.D., Wright J.D., and Clement B.M. (1991) Miocene isotope reference section, Deep Sea Drilling Project Site 608: an evaluation of isotope and biostratigraphic resolution. Paleoceanography 6, 33-52.

Nüremberg D., Bijma J., and Hemleben C. (1996) Assessing the reliability of Magnesium in foraminiferal calcite as a proxy for water mass temperatures. Geochim. Cosmochim. Acta 60, 803-814.

Oslick J.S., Miller K.G., and Feigenson M.D. (1994) Oligocene-Miocene strontium isotopes: stratigraphic revisions and correlations to an inferred glacioeustatic record. Paleoceanography 9, 427-443.

Patterson R.T., Blenkinsop J., and Cavazza W. (1995) Planktic foraminiferal biostratigraphy and ${ }^{87} \mathrm{Sr} / 86 \mathrm{Sr}$ isotopic stratigraphy of the Oligocene-to-Pleistocene sedimentary sequence in the southeastern Calabrian microplate, southern Italy. $J$. Paleont. 69, 7-20.

Paytan A., Kaster M., Martin E.E., Macdougall J.D., and Herbert T. (1993) Marine barite

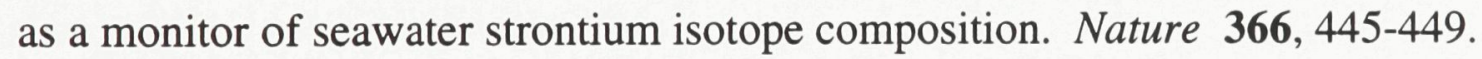

Pichler T. and Dix G.R. (1996) Hydrothermal venting within a coral reef ecosystem, Ambitle Island, Papua New Guinea. Geology 24, 435-438.

Popp N.B., Podosek F.A., Brannon J.C., Anderson T.F., and Pier J. (1986) ${ }^{87} \mathrm{Sr} / 86 \mathrm{Sr}$ in Permo-Carboniferous sea water from the analyses of well-preserved brachiopod shells. Geochim. Cosmochim. Acta 50, 1321-1328. 
Schmitz B., Åberg G., Werdelin L., Forey P., and Bendix-Almgreen S. E. (1991) ${ }^{87} \mathrm{Sr} / 86 \mathrm{Sr}, \mathrm{Na}, \mathrm{F}, \mathrm{Sr}$ and $\mathrm{La}$ in skeletal fish debris as a measure of the paleosalinity of fossil-fish habitats. Geol. Soc. of Amer. Bull. 103, 786-794.

Spero H.J., Lerche I., and Williams D.F., (1991) Opening the carbon isotope "vital effect" black box, 2, quantitative model for interpreting foraminiferal carbon isotope data. Paleoceanography 6, 639-655.

Stille P., Riggs R., Clauer N., Ames D., Crowson R., and Snyder S. (1994) Sr and Nd isotopic analysis of phosphorite sedimentation through one Miocene high-frequency depositional cycle on the North Carolina continental shelf. Mar. Geol. 117, 253-273.

Veizer J. (1983) Trace elements and isotopes in sedimentary carbonates. In Carbonates: mineralogy and chemistry (ed. R.J. Reeder), Vol. 11, Chap. 8, pp. 265-299. Mineralogical Society of America. 
Fig. 1-1. Location of the Lee Stocking Island study area within the Bahama Islands. 


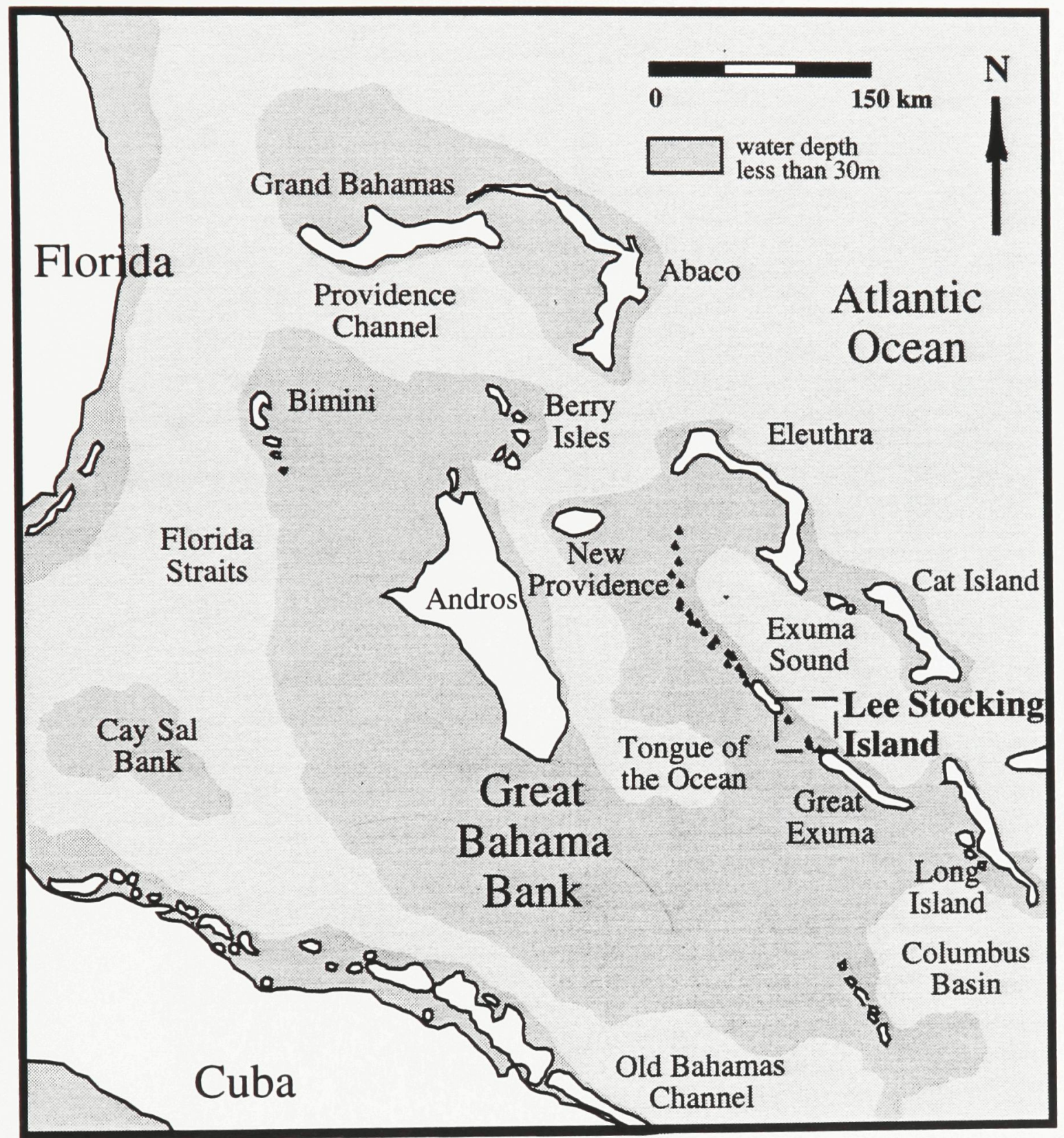


Fig. 1-2. Location of sample sites in the Lee Stocking Island area and the research facilities of the Caribbean Marine Research Center (CRMC). See text for a full description of sample localities. 


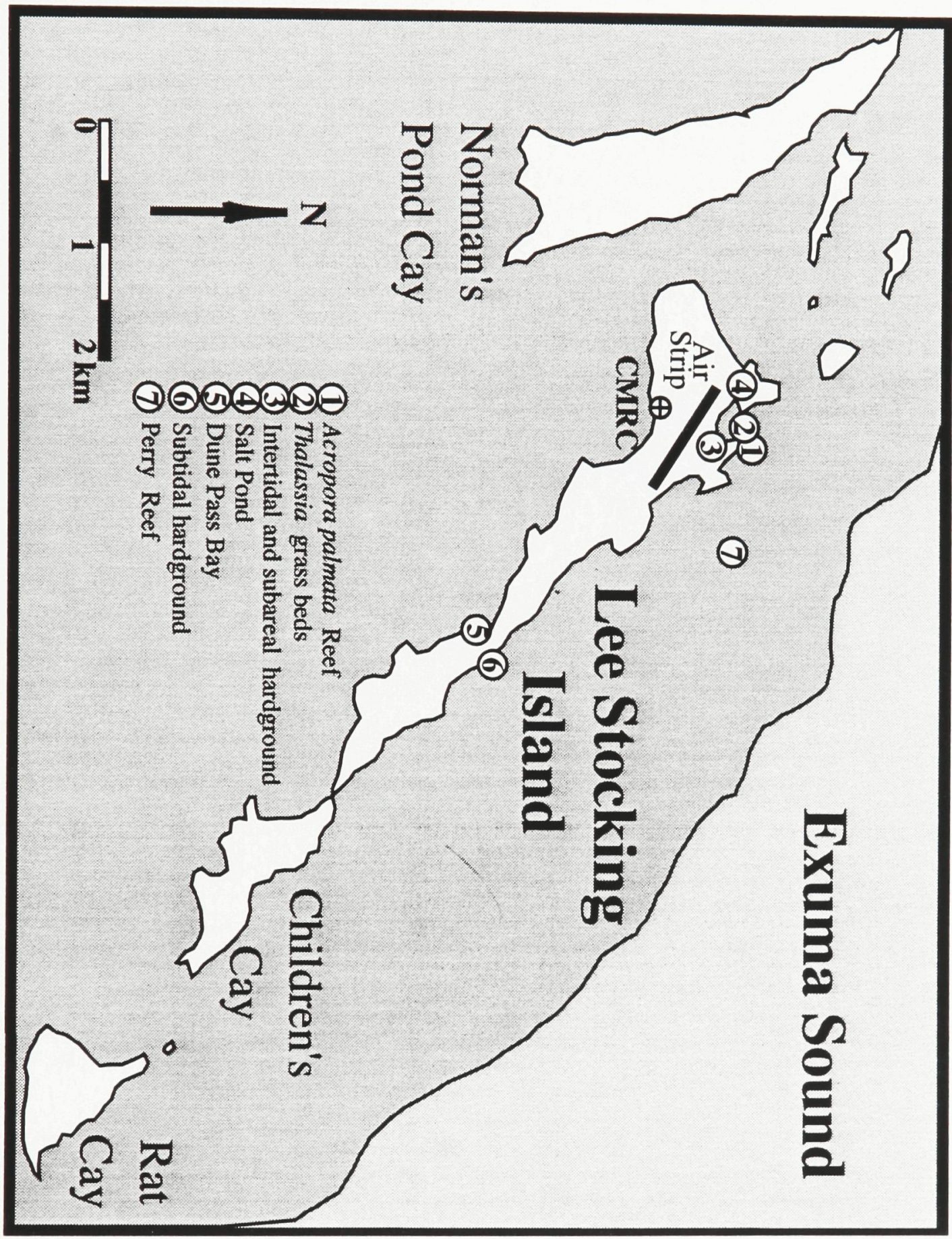


Fig. 1-3. Histogram showing normal frequency distribution for the forty ${ }^{87} \mathrm{Sr} / 86 \mathrm{Sr}$ analyses of the various taxa from the seven sample locations of Lee Stocking Island. 


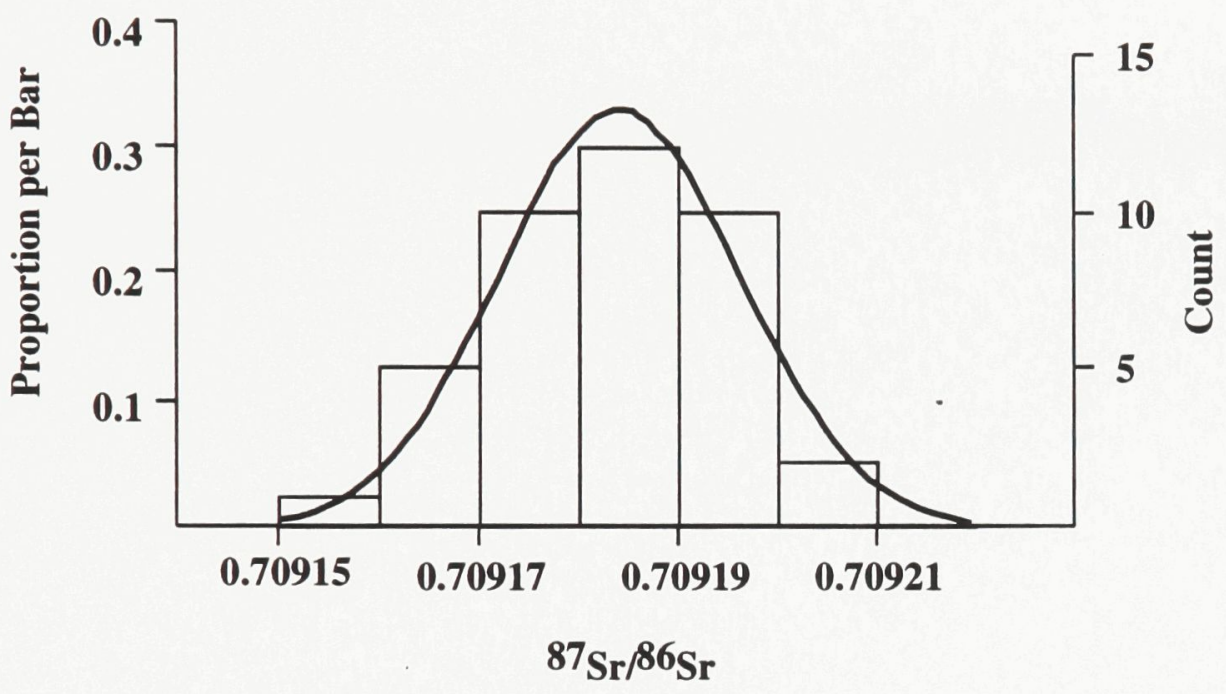


Fig. 1-4. Normal probability plot for Lee Stocking Island ${ }^{87} \mathrm{Sr} / 86 \mathrm{Sr}$ analyses, indicating a normal distribution. 


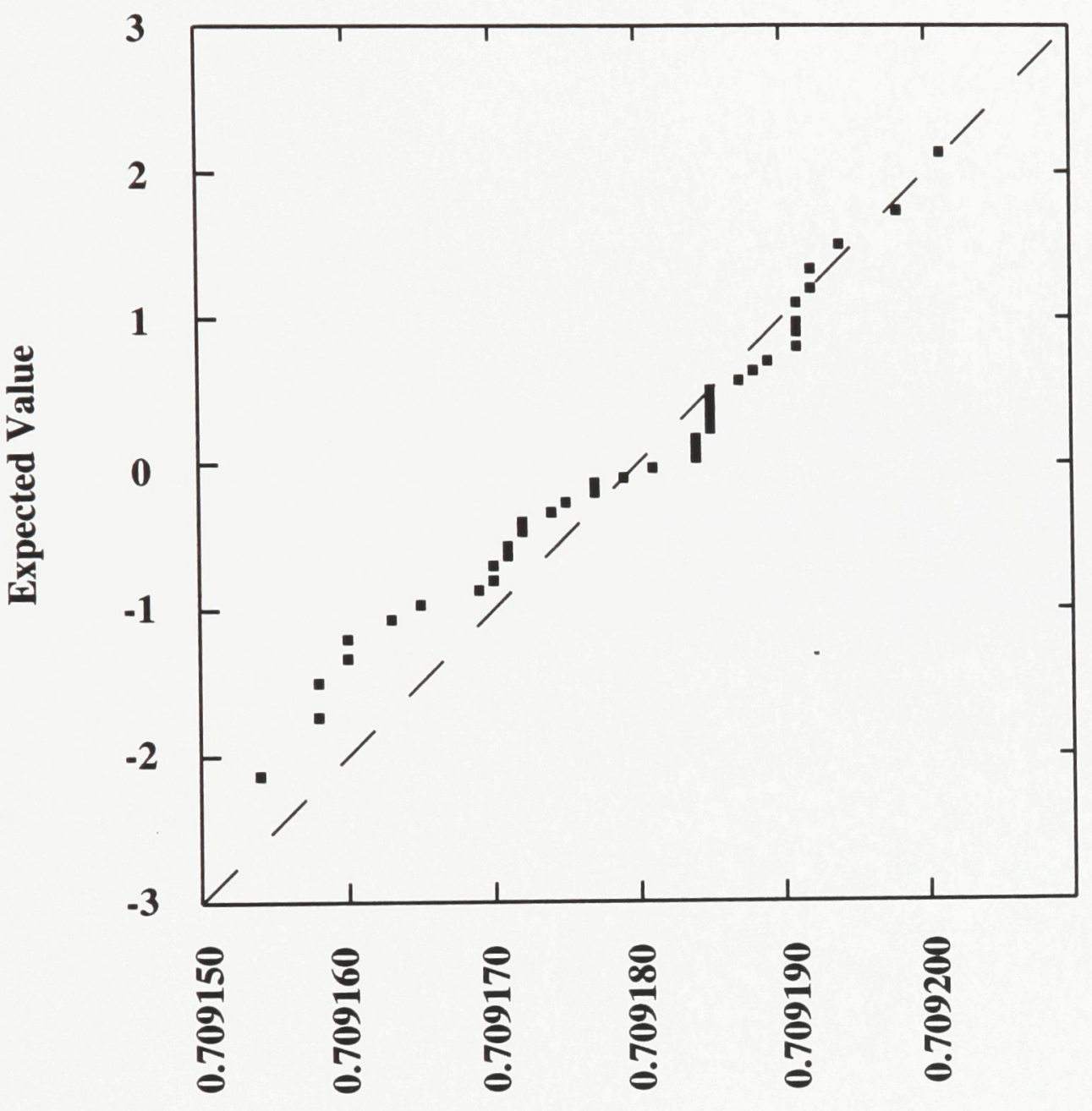

${ }^{87} \mathrm{Sr} /{ }^{86} \mathrm{Sr}$ 
Table 1-1. ${ }^{87} \mathrm{Sr} /{ }^{86} \mathrm{Sr}$ analyses grouped by location. See Fig. 1-2 and text for descriptions of the seven sample locations (1-7). The sample analysis statistics are reported as two standard deviations $(2 \sigma)$ as an indication of the quality of the measurements. 


\begin{tabular}{|c|c|c|c|c|c|c|}
\hline $\begin{array}{l}\text { Sample } \\
\text { Number }\end{array}$ & Taxa & Group & Loc. & $\begin{array}{c}\text { Weight } \\
\pm 0.00002 \mathrm{~g}\end{array}$ & $87 \mathrm{Sr} / 86 \mathrm{Sr}$ & $2 \sigma$ \\
\hline AIR-1 & Cittarium pica & gastropod & 3 & $7.96 \mathrm{E}-02$ & 0.709177 & 13 \\
\hline AIR-2 & Tectarius muricatus & gastropod & 3 & 8.06E-02 & 0.709184 & 14 \\
\hline AIR-3 & Nodilittorina tuberculata & gastropod & 3 & 7.40E-02 & 0.709174 & 11 \\
\hline AIR-4 & Truncatella pulchella & gastropod & 3 & $9.97 \mathrm{E}-02$ & 0.709201 & 9 \\
\hline AIR-5 & Littorina ziczac & gastropod & 3 & $5.47 \mathrm{E}-02$ & 0.709191 & 13 \\
\hline AIR-6 & Nerita versicolor & gastropod & 3 & $7.74 \mathrm{E}-02$ & 0.709181 & 8 \\
\hline AIR-7 & Littorina ziczac & gastropod & 3 & $3.15 \mathrm{E}-02$ & 0.709191 & 8 \\
\hline AR-1 & Clypeaster rosaceus & echinoderm & 1 & $6.72 \mathrm{E}-02$ & 0.709158 & 11 \\
\hline AR-2 & Siderastrea radians & coral & 1 & $1.11 \mathrm{E}-01$ & 0.709170 & 13 \\
\hline AR-3 & Hometrema rubrum & foraminifera & 1 & $2.41 \mathrm{E}-02$ & 0.709171 & 12 \\
\hline AR-4 & Leodia sexiesperforata & echinoderm & 1 & $5.27 \mathrm{E}-02$ & 0.709175 & 9 \\
\hline AR-5 & Chama congregata & bivalve & 1 & 4.49E-02 & 0.709158 & 10 \\
\hline AR-6 & Barbatia cancellarin & bivalve & 1 & $8.62 \mathrm{E}-02$ & 0.709165 & 12 \\
\hline AR-7 & Chlamys sentis & bivalve & 1 & $5.91 \mathrm{E}-02$ & 0.709192 & 15 \\
\hline AR-8 & Clypeaster rosaceus & echinoderm & 1 & $6.84 \mathrm{E}-02$ & 0.709179 & 14 \\
\hline AR-9 & Acropora palmata & coral & 1 & $9.59 \mathrm{E}-02$ & 0.709192 & 10 \\
\hline AR-10 & Millepora alcicornis & coral & 1 & $9.43 \mathrm{E}-02$ & 0.709185 & 15 \\
\hline AR-11 & Helioseris cucullata & coral & 1 & $1.05 \mathrm{E}-01$ & 0.709185 & 10 \\
\hline AR-18 & Asterigina sp. & foraminifera & 1 & $3.72 \mathrm{E}-03$ & 0.709191 & 9 \\
\hline DPB-1 & Porites furcata & coral & 5 & $1.17 \mathrm{E}-01$ & 0.709171 & 13 \\
\hline DPB-2 & Divaricella quadrisulcata & bivalve & 5 & $9.44 \mathrm{E}-02$ & 0.709169 & 8 \\
\hline DPB-3 & Laevicardium laevigatum & bivalve & 5 & $5.06 \mathrm{E}-02$ & 0.709160 & 16 \\
\hline DPB-4 & Batillaria minima & gastropod & 5 & $5.16 \mathrm{E}-02$ & 0.709154 & 14 \\
\hline DPB-5 & Lucine pensylvanica & bivalve & 5 & $9.02 \mathrm{E}-02$ & 0.709172 & 14 \\
\hline DPB-6 & Codakia orbicularis & bivalve & 5 & 8.92E-02 & 0.709172 & 15 \\
\hline DPB-7 & Atrina seminuda & bivalve & 5 & $7.45 \mathrm{E}-02$ & 0.709163 & 16 \\
\hline DPB-8 & Halimeda incrassata & algae & 5 & $3.41 \mathrm{E}-02$ & 0.709184 & 15 \\
\hline DPB-9 & Udotea flabellum & algae & 5 & $6.17 \mathrm{E}-03$ & 0.709185 & 10 \\
\hline DPB-11 & Soritid sp. & foraminifera & 5 & $6.60 \mathrm{E}-03$ & 0.709187 & 12 \\
\hline DPB-12 & Elphidid sp. & foraminifera & 5 & $2.45 \mathrm{E}-03$ & 0.709177 & 9 \\
\hline DPB-13 & Cibicides sp. & foraminifera & 5 & $1.37 \mathrm{E}-03$ & 0.709191 & 9 \\
\hline PR-1 & Madracis mirabilis & coral & 7 & 5.83E-02 & 0.709170 & 12 \\
\hline PR-2 & Diploria clivosa & coral & 7 & $9.17 \mathrm{E}-02$ & 0.709185 & 9 \\
\hline PR-3 & Dichocoenia stokesi & coral & 7 & 8.78E-02 & 0.709185 & 15 \\
\hline PR-4 & Montastrea annularis & coral & 7 & $1.44 \mathrm{E}-01$ & 0.709160 & 8 \\
\hline PR-5 & Meandrina meandrites & coral & 7 & $9.84 \mathrm{E}-02$ & 0.709198 & 17 \\
\hline PR-12 & Halimeda tuna & algae & 7 & 7.44E-02 & 0.709194 & 11 \\
\hline TGA-4 & Halimeda incrassata & algae & 2 & $8.85 \mathrm{E}-03$ & 0.709189 & 9 \\
\hline BC-1 & Terebra dislocata & gastropod & 4 & 2.33E-02 & 0.709184 & 6 \\
\hline WDPB-1 & Thais deltoidea & gastropod & 6 & $5.63 \mathrm{E}-02$ & 0.709188 & 12 \\
\hline
\end{tabular}


Table 1-2. Summary of ${ }^{87} \mathrm{Sr} / 86 \mathrm{Sr}$ distribution statistics and Chi-Squared test of the forty samples from Lee Stocking Island and the distribution statistics for our values of the NBS 987 standard over the analysis period. 


\begin{tabular}{lr}
\hline Num. of Cases & 40 \\
Min. Value & 0.709154 \\
Max. Value & 0.709201 \\
Range & 0.000047 \\
Mean & 0.709179 \\
Standard Dev. & 0.000012 \\
Standard Error & 0.000002 \\
Skewness & -0.327668 \\
Kurtosis & -0.836486 \\
Median & 0.709183 \\
Mode & 0.709185 \\
$\Delta 87 S r$ & $1071 \times 10 \mathrm{E}-6$ \\
\hline Chi-Squared & 2 \\
Deg. of Freedom & 1 \\
Critical value & 2.71 \\
10\% Sign. Level & \\
\hline SRM 987 & 10 \\
Num. of Cases & \\
Mean & 0.710250 \\
Standard Dev. & 0.000013 \\
Standard Error & 0.000004 \\
Median & 0.710248 \\
\hline
\end{tabular}




\section{CHAPTER 2. Testing the Application of Strontium Isotopes as a Paleosalinity Proxy: Lithologically Controlled Diagenetic Results.}

\section{ABSTRACT}

Strontium isotope analysis $\left({ }^{87} \mathrm{Sr} / 86 \mathrm{Sr}\right)$ of foraminiferal calcite from alternating marl-limestone couplets from the Trubi fm in southern Italy (Precariti stratigraphic section) revealed a cyclical signal that was initially attributed to precessionally controlled fluctuations in precipitation during the early Pliocene of the Mediterranean. The average oscillation in the ${ }^{87} \mathrm{Sr} / 86 \mathrm{Sr}$ values was just beyond the resolution of the Sr isotopic method $\left(2 \times 10^{-5}\right)$. However, an attempt to replicate these results using samples from a different, time equivalent section (Monte Singa) was not successful, indicating that our original results were affected by other factors. Detailed isotopic and geochemical analysis revealed subtle diagenetic contamination of our original results from the Precariti section.

Coccolith calcite in the Trubi fm. was altered both in its trace element $(\mathrm{Sr} / \mathrm{Ca}$, $\mathrm{Mg} / \mathrm{Ca}, \mathrm{Fe} / \mathrm{Ca}, \mathrm{Mn} / \mathrm{Ca}, \mathrm{Na} / \mathrm{Ca}$ all were higher) and isotopic $\left({ }^{87} \mathrm{Sr} / 86 \mathrm{Sr}, \delta^{18} \mathrm{O}, \delta^{13} \mathrm{O}\right)$ composition from its original values. The coccolith ${ }^{87} \mathrm{Sr} / 86 \mathrm{Sr}$ values (limestones 0.709010; marls 0.7089512) were lower than Pliocene seawater (0.70904-8) and similar to the ${ }^{87} \mathrm{Sr} /{ }^{86} \mathrm{Sr}$ values for Messinian evaporites $(0.70885-95)$. SEM analysis revealed that the coccoliths were overgrown. Elevated trace element values in both the coccolith calcite and the porewaters suggest alteration by Messinan evaporite derived brines early in the diagenetic history of the Trubi fm.

The foraminiferal calcite was unaltered and retained its trace elemental and isotopic composition. The ${ }^{87} \mathrm{Sr} /{ }^{86} \mathrm{Sr}$ values of the foraminiferal calcite record the composition of Pliocene seawater. Therefore, our original cyclical results from the Precariti section can be attributed to improper cleaning procedures which did not completely remove the coccolith calcite from the foraminifera before Sr isotopic analysis. In contrast, the Monte Singa 
samples were subjected to a more rigorous cleaning procedure (preleaching $0.01 \mathrm{~N} \mathrm{HCl}$ ) that removed the altered coccolith fraction. The original cyclical ${ }^{87} \mathrm{Sr} /{ }^{86} \mathrm{Sr}$ signal in the Precariti section can therefore be ascribed to the lower ${ }^{87} \mathrm{Sr} /{ }^{86} \mathrm{Sr}$ values in the coccoliths from the marls and not to precessionally-controlled variation.

Results of this study indicate that (1) a thorough examination of the sample constituents is crucial in order to select the most appropriate cleaning procedure, and (2) bulk-rock analysis can provide erroneous results, particularily if the various constituents of the samples have had a diagenetic history. 


\section{INTRODUCTION}

The strontium contained in marine carbonates records the ${ }^{87} \mathrm{Sr} /{ }^{86} \mathrm{Sr}$ ratio of seawater at the time of crystallization. The isotopic composition of strontium in seawater at any time is determined primarily by the balance between the deep-sea hydrothermal input of strontium of mantle origin (presently, $1 \times 10^{6} \mathrm{t} / \mathrm{yr}$ ) and the fluvial flux derived from continental weathering ( $\left.3 \times 10^{6} \mathrm{t} / \mathrm{yr}\right)$ (Palmer and Edmond, 1989; Mc Arthur, 1991). The ${ }^{87} \mathrm{Sr} /{ }^{86} \mathrm{Sr}$ ratio of oceanic water has slowly changed during geologic time as the balance between these factors has varied. Therefore, the strontium isotopic composition of marine carbonates may be used as a chronostratigraphic tool (e.g. Wickman, 1948; Burke et al., 1982; De Paolo and Ingram, 1985; Miller et al., 1988, 1990; Hodell et al., 1991; Patterson et al., 1995). The ocean strontium isotope record has also been used as a proxy for changes in chemical weathering rates over geologic time (e.g. Capo and DePaolo, 1990; Hodell et al., 1990; Krishnaswami et al., 1992; Palmer and Edmond, 1992; Richter et al., 1992).

Environments in close proximity to sources of strontium input (i.e. hydrothermal and fluvial) may have ${ }^{87} \mathrm{Sr} / 86 \mathrm{Sr}$ ratios that deviate from that of normal seawater (Bryant et al., 1995; Pichler and Dix, 1996). As an example, this deviation has been used to determine paleosalinity variations in marginal marine deposits from an estuarine environment of San Francisco Bay during the last interglacial (Ingram and Sloan, 1992). The goal of the present study was to determine whether a combined micropaleontological and strontium isotope study could be used as a paleoceanographic (paleosalinity) indicator in a large restricted basin like the Mediterranean Sea. To achieve this goal, we tested the methodology on two exposures (Precariti and Monte Singa section) of the Pliocene Trubi formation from the Calabria region in southern Italy (Patterson et al., 1995; Fig. 2-1).

Previous high resolution strontium isotopic studies (Dia et al., 1992; Clemens et al., 1993) appeared initially to be very promising. The studies suggested that the open ocean ${ }^{87} \mathrm{Sr} /{ }^{86} \mathrm{Sr}$ record varied with Milankovitch cyclicity as a result of short term climatic 
changes of $10^{3}-10^{4}$ years (Dia et al., 1992; Clemens et al., 1993). However, attempts to replicate the variation were unsuccessful (Henderson et al., 1993; Clemens et al., 1995 ). To test further the utility of the high resolution technique to discriminate subtle paleoceanographic changes we chose to examine samples from a more highly restricted setting (i.e. Mediterranean Sea) where any strontium isotopic changes would tend to be maximized (Richter and Turekian, 1993).

\section{Background Geology}

The Trubi Formation (Early Pliocene) is a lithostratigraphic marine sedimentary unit which is present over most of the Mediterranean region. It is characteristically composed of alternating carbonate-rich and carbonate-poor marl layers. The base of the Trubi fm represents the restoration of open marine conditions in the Mediterranean Sea following the Messinian desiccation (Hsu et al., 1977; Cita, 1982). The sudden post-Messinian reduction of peri-Mediterranean continental area (and the corresponding deep drowning of the Messinian coastal accumulations of sediment) produced a decrease of detrital input to the Mediterranean Sea until the sediment dispersal system reached a new equilibrium with the raised base level. In the absence of significant terrigenous input, the influence of climatic variations on early Pliocene intrabasinal sedimentation would have been maximal. Previous time series and cross-spectral analysis of isotopic, geochemical and micropaleontological data from the Trubi fm, coupled with detailed biostratigraphic and paleomagnetic calibration (Gudjonsson, 1987; Hilgen, 1987; De Visser et al., 1989; Thunell et al., 1991; Lourens et al., 1992), have indicated that a significant amount of the variance of these parameters reacted strongly to Milankovitch precessional changes in insolation with quasi-periodicity of $21.7 \mathrm{ka}$ (Hilgen and Langereis, 1989).

Two hypotheses, both based on the influence of Milankovitch precessional oscillations on climate, have been proposed to explain the observed cyclicity in the Trubi fm. One hypothesis associates the darker, carbonate-poor marls with periods of increased 
continental runoff, greater terrigenous influx, and higher surface water productivity due to nutrients and organic matter carried by rivers flowing into the Mediterranean. The lighter, carbonate-rich limestones are attributed to drier climatic conditions and low surface-water productivity (Gudjonsson, 1987; Hilgen, 1987; De Visser et al., 1989; Lourens et al., 1992). The second hypothesis attributes the carbonate-rich limestones to intensified winds associated with precession maxima resulting in increased upwelling, higher productivity, and carbonate deposition; within this scenario the carbonate-poor marls are consequently associated with time intervals of warm surface waters and oligotrophic conditions (Thunell et al., 1991).

The exposures of the Trubi fm were selected to test the applicability of strontium isotopic methodology as a paleoceanographic tool for the following reasons: 1) the Mediterranean was a restricted basin in the Pliocene with only the strait of Gibraltar open to the Atlantic Ocean; 2) the Trubi fm is well dated by magnetostratigraphy and biostratigraphy; the ${ }^{87} \mathrm{Sr} /{ }^{86} \mathrm{Sr}$ signal for Pliocene seawater is known and therefore, if diagenesis can be ruled out, any deviation from this value can be attributed to continental influence; 3) the cyclic sedimentation (marls/limestone) indicates an alternating environmental control, possibly related to Milankovitch forcing of climate. This cyclicity is a very good control for the interpretation of the strontium isotope signal; 4) there is controversy regarding the creation of the marl/limestone couplets, with one hypothesis invoking increased/decreased continental runoff; therefore, the application of strontium isotopic methodology, if successful, could add new information to the environmental interpretation of the Trubi fm; 5) there are very good exposures of the Trubi fm in southern Italy that are easily accessible for sampling and which provide a continuous succession of marl/limestone couplets; 6) there is a substantial amount of previous micropaleontological research published on these sections which indicates that foraminiferal preservation is very good, with no overgrowths or evidence of dissolution or aberrant stable isotopic ( $\mathrm{O}$ and $\mathrm{C}$ ) values (Gudjonsson, 1987; De Visser et al., 1989; Thunell et al., 1991; Lourens et al., 
1992; Patterson et al., 1995); and 7) there is a significant amount of strontium isotopic data pertaining to various rivers emptying into the Mediterranean, some of which have high outflows (i.e. the River Nile; Brass, 1976; Emelyanov and Shimkus, 1986).

\section{Previous Results \\ Precariti Section}

Seventeen slightly indurated marl and limestone samples from the Precariti section of the Trubi fm were analyzed (Fig. 2-2; see Appendix 2-1 for analytical methods). The ${ }^{87} \mathrm{Sr} / 86 \mathrm{Sr}$ ratios measured from planktic foraminifera (Globigerinoides obliquus) extracted from the Precariti section of the Trubi fm oscillated in harmony with the marl and limestone lithologies. The values from the carbonate-rich limestones, with a mean value of 0.709044 $\pm 14(2 \sigma)$, were generally higher than the values from the marls and correlated well with the open-ocean ${ }^{87} \mathrm{Sr} /{ }^{86} \mathrm{Sr}$ value $(0.70906 \pm 2(2 \sigma)$; Farrell et al., 1995) for the age of the section $(4.5$ to $4.3 \mathrm{Ma})$. The age of the section has been independantly dated using the chronostratigraphic boundaries of the G. margaritae biozone (4.64 - 4.13 Ma; Langereis and Hilgen, 1991), the stratigraphic correlation of our section with the nearby paleomagnetically dated Monte Singa section 1 (Hilgen, 1987) and the average sedimentation rate of 21.7 ka per couplet (Hilgen and Langereis, 1989; Fig. 2-2; Table 21). The carbonate-poor marls had consistently lower ${ }^{87} \mathrm{Sr} /{ }^{86} \mathrm{Sr}$ ratios with a mean of $0.709022 \pm 12(2 \sigma)$ and were lower than the value for Pliocene seawater. Although the magnitude of the oscillation fell (average shift of ${ }^{87} \mathrm{Sr} /{ }^{86} \mathrm{Sr}$ ratios is $2.2 \times 10^{-5}$ ) within the uncertainty associated with strontium isotopic measurements $\left( \pm 2 \times 10^{-5}\right)$ the regularity of the signal and the consistent agreement between rock type and the ${ }^{87} \mathrm{Sr} / 86 \mathrm{Sr}$ values suggested that the oscillations were not an analytical artifact (Fig. 2-2; Table 2-1). Based on these results and the modelling of the response of the Mediterranean ${ }^{87} \mathrm{Sr} / 86 \mathrm{Sr}$ signal to the modern collective fluvial ${ }^{87} \mathrm{Sr} /{ }^{86} \mathrm{Sr}$ ratio $(0.7082)$ of the major rivers (Nile, Po, and the Rhone) debouching into the Mediterranean, we developed a hypothesis that the marls were 
deposited under increased continental runoff due to a wetter climate. The model did not necessitate a homogeneous mixing and dilution of Mediterranean seawater in that the planktic foraminifera would be recording the ${ }^{87} \mathrm{Sr} / 86 \mathrm{Sr}$ ratio of the upper water surface which could have been affected by hypopicnal flow due the increased continental runoff. The limestones, with their higher ${ }^{87} \mathrm{Sr} / 86 \mathrm{Sr}$ ratios similar to Pliocene seawater, were considered to be from drier intervals with diminished freshwater influence.

The results of the $\mathrm{Sr}$ analyses $\left({ }^{87} \mathrm{Sr} / 86 \mathrm{Sr}\right)$ from the Precariti section were considered reliable since: 1) SEM examination (JEOL 6400 at the Carleton University Scanning Electron Microscope Facility) and thin section observations of foraminifera tests showed no diagenetic alteration, 2) the samples contained no cement, and 3) previous $\mathrm{O}$ and $\mathrm{C}$ isotopic studies revealed no abnormal values (Gudjonsson, 1987; De Visser et al., 1989; Thunell et al., 1991; Lourens et al., 1992). Therefore, we believed that the systematic alternation of the ${ }^{87} \mathrm{Sr} / 86 \mathrm{Sr}$ values was probably real and due to freshwater influence and not diagenesis or a lithologically controlled effect. However, since the ${ }^{87} \mathrm{Sr} / 86 \mathrm{Sr}$ difference between the marls and the limestones was comparable with analytical precision $\left( \pm 2 \times 10^{-5}\right)$, and previous high resolution strontium isotope research had been recanted (i.e. Clemens et al., 1995) we decided to test another section of the Trubi fm to determine whether our results could be replicated.

\section{Monte Singa Section}

To substantiate the initial results from the Precariti section, 24 marl and limestone samples of the Trubi fm from the Monte Singa location were selected and analyzed (Fig. 23). The same procedure to disaggregate the samples was used for the Precariti section samples, and individual foraminiferal specimens (Globigerinoides obliquus) were again hand picked (see Appendix 2-1). Although there was no reason to believe that the cleaning and dissolution procedure used in the analysis of the samples from the Precariti section was biasing the results, a different more rigorous cleaning procedure was used on the Monte 
Singa samples as a precaution, since the observed changes in the ${ }^{87} \mathrm{Sr} /{ }^{86} \mathrm{Sr}$ ratios were so small (see Apppendix 2-1 for analytical methods).

Unfortunately, the ${ }^{87} \mathrm{Sr} / 86 \mathrm{Sr}$ ratios in the Monte Singa section did not oscillate with lithology as had been observed in the Precariti section (Fig. 2-3; Table 2-1). The values of the ${ }^{87} \mathrm{Sr} /{ }^{86} \mathrm{Sr}$ ratios in both the marls and the limestones in the Monte Singa section had a mean of $0.709052 \pm 22(2 \sigma)$, which is slightly higher than the mean value for the marls and the limestones from the Precariti section at $0.709033 \pm 26$ (2б) (Fig. 2-3; Table 2-1). Although these two sample means are similar within analytical uncertainty $( \pm 2$ $\left.\mathrm{x} 10^{-5}(2 \sigma)\right)$, they are significant since the difference between the two are equal to the apparent shift in the ${ }^{87} \mathrm{Sr} / 86 \mathrm{Sr}$ ratios between the marls and the limestones originally seen in the Precariti section. We were not convinced that the observed signal was due solely to analytical uncertainty associated with the mass spectrometry because the large number of marl and limestone samples analyzed and the consistent difference in the ${ }^{87} \mathrm{Sr} / 86 \mathrm{Sr}$ ratios observed suggested a diagenetic or lithologic control for the variance. In order to isolate further the observed effect the same cleaning and dissolution methodology was applied to six replicate samples from the Precariti section.

The replicate analyses of Precariti section using the more rigorous cleaning procedure did not reproduce the results obtained in the initial analyses. Although, some of the samples did follow a cyclical pattern, the second suite of analyses had a mean value of $0.709048 \pm 24(2 \sigma)$ which was higher than the value obtained in the initial analyses (mean of $0.709033 \pm 26$ ) but similar to the mean value of the Monte Singa section $0.709052 \pm 22$ $(2 \sigma)$ (Fig. 2-2; Table 2-1).

Results from the Monte Singa section and the replicate samples from the Precariti section indicate a discrepancy between the ${ }^{87} \mathrm{Sr} / 86 \mathrm{Sr}$ values obtained using the different cleaning and dissolution procedures. The more rigorous cleaning procedure would have reduced the impact of any carbonate contaminant (cleaning with $0.01 \mathrm{~N} \mathrm{HCl}$ ). The only 
possible carbonate soluble contaminant was coccoliths (there was no cement); however, their ${ }^{87} \mathrm{Sr} /{ }^{86} \mathrm{Sr}$ values should have been similar to those obtained for the foraminifera.

Two possible causes for the different strontium values obtained using the preparation methodologies were considered: 1) minor diagenetic alteration of nannofossil chalk (McArthur et al., 1993a, b and see McArthur, 1994) and 2) the dissolution of the terrigenous clay component by the stronger $\mathrm{HCl}$ during dissolution (McArthur, 1994). However, this component is generally more radiogenic and could not have generated the observed lower ${ }^{87} \mathrm{Sr} /{ }^{86} \mathrm{Sr}$ ratios in the marls (McArthur, 1994).

\section{GEOCHEMICAL ANALYSES}

To determine the contaminating phase that was possibly affecting the isotopic results, the various components of four samples from the Monte Singa section were isolated. The investigation started by examining the strontium isotopic composition of whole rock samples using both the strong acetic $(80 \%)$ and $\mathrm{HCl}$ acid $(2.5 \mathrm{~N})$ dissolution methodologies (Table 2-2). Both methods produced significantly lower ratios than those obtained using hand picked foraminifera, and the marls had lower values compared to the limestones. The significantly lower ${ }^{87} \mathrm{Sr} /{ }^{86} \mathrm{Sr}$ ratios in the bulk samples could potentially account for the lower ratios in the previous results. Therefore, it was important to isolate and determine the source of the lower ratios within the bulk rock samples.

To isolate the contaminating fraction both the isotopic $(\mathrm{O}, \mathrm{C}, \mathrm{Sr})$ and the trace element composition $(\mathrm{Mg}, \mathrm{Sr}, \mathrm{Fe}, \mathrm{Mn}, \mathrm{Na}$ ) of the sample constituents were examined. These constituents included the carbonate (coccoliths) and the terrigenous fractions of the $<53$ micron size sediment, as well as the $>53$ micron size sediment (foraminifera), and the porewater (see Appendix 2-2 for analytical methods). The use of trace elements and isotopic analyses has been shown to be an important technique in the assessment of diagenetic alteration (Popp et al., 1986; Bates and Brand, 1991; Carpenter et al., 1991; Veizer et al., 1992; Denison et al., 1994; see McArthur (1994) for a full discussion). 
Analysis of porewater was conducted on 8 samples (SN2, SN3, SN7, SN8, SN18, SN19, SN20, SN21) from the Monte Singa section and, for comparative purposes, 4 samples were also analyzed from an outcrop of the Trubi fm at Eraclea Minoa in Sicily (EM4, EM5, EM16, EM17; see Hilgen, 1991 for location map).

\section{GEOCHEMICAL RESULTS}

\section{Strontium Isotopic Ratios}

The four components of the marl and limestone lithologies displayed significantly different strontium isotopic ratios (Fig. 2-4; Table 2-2; Table 2-3). The terrigenous residues from the four samples from the Monte Singa section (SN2, SN3, SN7, SN8) were more radiogenic as expected, with ratios ranging from 0.716167 to 0.716912 .

The porewater ${ }^{87} \mathrm{Sr} / 86 \mathrm{Sr}$ values were also surprisingly high in the lower four samples (SN2, SN3, SN7, SN8; Table 2-3) from the Monte Singa section, with values ranging from 0.709147 to 0.709161 which are close to that of modern seawater (0.70918). Analysis of four other samples from further up the section (SN18, SN19, SN20, SN21) also produced high values ( 0.709096 to 0.709108$)$, although these were lower than the values from the basal samples. The four porewater values from the Eraclea Minoa section, in contrast to the Monte Singa section, were very low with values that ranged from 0.709007 to 0.709031 (Table 2-3).

The coarse fraction was analysed on a bulk sample of foraminiferal tests and the ratios were very similar to results obtained from samples analyzed in the original investigation which used exclusively specimens of Globigerinoides obliquus (Table 2-1; Table 2-2). The foraminiferal samples from the Monte Singa section all had ${ }^{87} \mathrm{Sr} / 86 \mathrm{Sr}$ values reflecting Pliocene seawater, and were much lower than the values obtained from terrigenous material and porewater (Table 2-2; Fig. 2-4; Fig. 2-5). The samples from the Eraclea Minoa section (EM4, EM5, EM16, EM17) had slightly lower ${ }^{87} \mathrm{Sr} / 86 \mathrm{Sr}$ values, with a mean of 0.709020 (Table 2-3; Fig. 2-5). The relationship between the ${ }^{87} \mathrm{Sr} / 86 \mathrm{Sr}$ 
values of the porewater and the foraminiferal calcite distinguished three groupings of samples (Fig. 2-5). The lower Monte Singa samples were not analytically different in their foraminiferal calcite from the upper samples; however, they did have much higher porewater values. The Eraclea Minoa samples had significantly lower ${ }^{87} \mathrm{Sr} / 86 \mathrm{Sr}$ values than the Monte Singa samples, and their porewater and foraminiferal values were equal to each other when analytical uncertainty was considered.

The coccoliths within the samples had significantly lower ${ }^{87} \mathrm{Sr} / 86 \mathrm{Sr}$ ratios than the foraminifera (Table 2-2; Fig. 2-4). The difference between the foraminiferal and coccolith ${ }^{87} \mathrm{Sr} / 86 \mathrm{Sr}$ values in the marls $\left(\mathrm{SN} 2=1.03 \times 10^{-4} ; \mathrm{SN} 8=6.7 \times 10^{-5}\right)$ was much greater than in the limestone samples $\left(\mathrm{SN} 3=2.7 \times 10^{-5} ; \mathrm{SN} 7=3.5 \times 10^{-5}\right)$. The difference between the coccolith and foraminiferal ratios is significant $\left( \pm 2 \times 10^{-5}(2 \sigma)\right)$ in the marls but within the error limits in the limestones.

\section{Trace Element, $\mathrm{O}$ and $\mathrm{C}$ Isotopic Composition}

Trace elemental analysis of the four fractions (porewater, coccoliths, foraminifera and terrigenous components) also revealed dramatically different chemical compositions which emphasized the heterogeneity of the marl and limestone samples (Fig. 2-6; Fig. 2-7; Table 2-4; Table 2-5; Table 2-6).

The foraminifera within the limestone and marl samples had lower $\mathrm{Fe} / \mathrm{Ca}$ and $\mathrm{Mn} / \mathrm{Ca}$ ratios with respective means of $1.3 \times 10^{-3}$ and $1.2 \times 10^{-3}$, and were closely clustered. The coccoliths had higher $\mathrm{Fe} / \mathrm{Ca}$ and $\mathrm{Mn} / \mathrm{Ca}$ ratios $\left(6.9 \times 10^{-3}, 3.9 \times 10^{-3}\right)$ compared to the foraminifera and they had a larger spread of values (Fig. 2-6; Table 2-6). There did not seem to be any consistent relationship between the $\mathrm{Mn} / \mathrm{Ca}$ and $\mathrm{Fe} / \mathrm{Ca}$ values of the coccoliths and elevation within the section although the $\mathrm{Fe} / \mathrm{Ca}$ levels were higher in the samples from SN7 and SN8 (Fig. 2-6; Table 2-6).

$\mathrm{The} \mathrm{Mg} / \mathrm{Ca}$ and $\mathrm{Sr} / \mathrm{Ca}$ ratios were also lower and more closely clustered in the foraminifera (mean: $5.4 \times 10^{-3}, 1.5 \times 10^{-3}$ ) than in the coccoliths which had ratios that were 
significantly higher (mean: $1.9 \times 10^{-2}, 2.3 \times 10^{-3}$; Fig. 2-6; Table 2-6). There is no apparent relationship between the $\mathrm{Sr} / \mathrm{Ca}$ ratios and the ${ }^{87} \mathrm{Sr} / 86 \mathrm{Sr}$ values of the coccoliths or foraminifera, although the coccoliths are more widely spread and the coccoliths in the marls do have lower ${ }^{87} \mathrm{Sr} / 86 \mathrm{Sr}$ values (Fig. 2-6; Table 2-2; Table 2-6). Although the sample size is small, the coccolith $\mathrm{Mg} / \mathrm{Ca}$ ratios and their ${ }^{87} \mathrm{Sr} /{ }^{86} \mathrm{Sr}$ values do show a general inverse relationship with the lower ${ }^{87} \mathrm{Sr} / 86 \mathrm{Sr}$ ratios and higher $\mathrm{Mg} / \mathrm{Ca}$ values associated with the marl lithologies (Fig. 2-6; Table 2-6).

The $\delta^{18} \mathrm{O} \%$ and $\delta^{13} \mathrm{C} \%$ (PDB) values of the coccoliths and the foraminifera were also consistently different (Table 2-6). The coccolith $\delta^{18} \mathrm{O} \%$ and $\delta^{13} \mathrm{C} \%$ (PDB) values were closely clustered. The oxygen ranged from 0.07 to $0.94( \pm 0.15(2 \sigma))$ and the carbon ranged from 0.17 to $0.77( \pm 0.10(2 \sigma))$. The foraminifera were less consistent and had $\delta^{18} \mathrm{O} \%_{0}(\mathrm{PDB})$ values that were negative, ranging from -1.73 to $-4.30( \pm 0.15(2 \sigma))$ and the $\delta^{13} \mathrm{C} \%$ (PDB) values ranging from -0.24 to $+1.58( \pm 0.10(2 \sigma)$; Fig. 2-6; Table 2-6). A plot of $\mathrm{Mn} / \mathrm{Ca}$ ratios and the oxygen isotope values demonstrated the geochemical segregation of the foraminifera from the coccoliths with the foraminifera exhibiting negative oxygen values and lower $\mathrm{Mn} / \mathrm{Ca}$ ratios (Fig. 2-6; Table 2-6).

The geochemical composition of the terrigenous fraction was distinct from the carbonate fractions (Table 2-6). The calcium concentration in the terrigenous fraction was low resulting in very high ratios of $\mathrm{Mg} / \mathrm{Ca}, \mathrm{Sr} / \mathrm{Ca}, \mathrm{Fe} / \mathrm{Ca}, \mathrm{Na} / \mathrm{Ca}$ and $\mathrm{Mn} / \mathrm{Ca}$ (Table 2-4; Table 2-6). The $\mathrm{Mg}, \mathrm{Na}$, and concentration values themselves were all higher than in the carbonate fractions and the Fe concentrations were significantly higher with an average value of 39.8 ppt. The high Fe concentrations are to be expected in light of the kaolinite and chlorite mineralogy and the presence of abundant iron oxides and hydroxides which stain the rocks.

The analysis of porewater geochemistry revealed relationships between the different concentrations of trace elements and with the strontium isotopic values. There was a general linear trend $\left(r^{2}=0.64\right)$ in the Monte Singa $\mathrm{Mg} / \mathrm{Ca}$ and $\mathrm{Sr} / \mathrm{Ca}$ porewater ratios that 
did not follow any relationship with height in the section or with lithology (Table 2-6; Fig. 2-7). The Eraclea Minoa $\mathrm{Mg} / \mathrm{Ca}$ and $\mathrm{Sr} / \mathrm{Ca}$ porewater ratios were very scattered compared to the Monte Singa samples and followed no clear relationship (Table 2-6; Fig. 2-7). The samples from both sections had very similar $\mathrm{Sr} / \mathrm{Ca}$ values that were higher than the modern $\mathrm{Sr} / \mathrm{Ca}$ seawater value. The $\mathrm{Mg} / \mathrm{Ca}$ porewater values from the Monte Singa section all had values that were lower than modern seawater. The Eraclea Minoa porewater samples although more highly scattered, had $\mathrm{Mg} / \mathrm{Ca}$ values that were commensurate to, or higher than, the modern seawater value (with the exception of one sample; Table 2-6; Fig. 2-7).

The $\mathrm{Mn} / \mathrm{Ca}$ and the $\mathrm{Fe} / \mathrm{Ca}$ ratios in the porewater from both the Monte Singa and the Eraclea Minoa sections showed no clear relationships with lithology or elevation (Table 26; Fig. 2-7). However, the basal samples from the Monte Singa section did have higher $\mathrm{Mn} / \mathrm{Ca}$ and $\mathrm{Fe} / \mathrm{Ca}$ values, although they were highly scattered.

$\mathrm{The} \mathrm{Na} / \mathrm{Ca}$ and the $\mathrm{Mg} / \mathrm{Ca}$ ratios displayed direct relationships in both sections. The Monte Singa section exhibited a general trend; with increasing $\mathrm{Na} / \mathrm{Ca}$ values there was a slight increase in $\mathrm{Mg} / \mathrm{Ca}$ ratios. The Eraclea Minoa samples displayed a wider range in $\mathrm{Mg} / \mathrm{Ca}$ ratios relative to the $\mathrm{Na} / \mathrm{Ca}$ levels and had a better $\mathrm{r}^{2}$ value at 0.84 . The $\mathrm{Na} / \mathrm{Ca}$ values from the Eraclea Minoa section were similar to that of modern seawater, and in the Monte Singa section the values were all higher (Table 2-6; Fig. 2-7).

The ${ }^{87} \mathrm{Sr} /{ }^{86} \mathrm{Sr}$ values and $\mathrm{Na} / \mathrm{Ca}$ ratios exhibited a very strong direct linear $\left(r^{2}=0.83\right)$ relationship in the Monte Singa section. The ${ }^{87} \mathrm{Sr} / 86 \mathrm{Sr}$ values varied considerably between the two sections with the Eraclea Minoa samples exhibiting lower and more closely clustered values (Table 2-6; Fig. 2-7). 


\section{DISCUSSION}

The diagenetic history of the subaerial exposures of the Trubi fm (Monte Singa and Precariti sections) is complex and has differentially affected the various components making up these hemipelagic rocks. The Trubi fm was deposited in a forearc basin with a significant detrital input that produced moderate to high deposition rates (Gudjonsson, 1987). It was also subjected to moderate burial depths (minimum of $225 \mathrm{~m}$; Zijderweld et al., 1991; Patterson et al., 1995). Uplift and subaerial exposure of the two sections occured sometime during the late Quaternary (e.g., Barrier and Montenat, 1987). The underlying Messinian lithologic unit in the area of the Precariti and Monte Singa sections is composed of an alluvial fan conglomerate (DeCelles and Cavazza, 1995; Patterson et al., 1995; Cavazza et al., in press). Messinian evaporites which commonly underlie the fan conglomerates in other areas are absent from the studied sections (Patterson et al., 1995).

The consequent result of this geological background (burial and uplift) and the stratigraphic setting of the Monte Singa and the Precariti sections have produced a very complex diagenetic history for the Trubi $\mathrm{fm}$ in this area.

\section{Foraminifera Preservation}

The foraminifera from the four samples analyzed in detail from the Monte Singa section retained their original ${ }^{87} \mathrm{Sr} / 86 \mathrm{Sr}$ isotopic composition and were not significantly altered from their original low-Mg calcite mineralogy (Table 2-2). The foraminifera also retained much of their original trace element composition (Table 2-4; Table 2-6). The $\mathrm{Na} / \mathrm{Ca}$ ratios of the foraminifera ranged from 3.0 to $3.7 \times 10^{-3}$ which is slightly lower than reported values from recent and subrecent planktic foraminifera, which typically range from 4.0 to $7.0 \times 10^{-3}$ (Bender et al., 1975; Lorens et al., 1977; Graham et al., 1982; Delaney et al., 1985; Puechmaille, 1994). The lower $\mathrm{Na} / \mathrm{Ca}$ ratios could be indicative of slight alteration of the foraminiferal tests. However, the incorporation of $\mathrm{Na}$ into calcite is not as well understood as other trace elements (Graham et al., 1982). The lower ratios could be 
due to slight diagenetic alteration or environmental parameters that affected the uptake of $\mathrm{Na}$ by the planktic foraminifera (Land and Hoops, 1973; Kitano et al., 1975; White, 1978; Graham et al. 1982).

The $\mathrm{Mn} / \mathrm{Ca}$ and $\mathrm{Fe} / \mathrm{Ca}$ levels within the planktic foraminifera from the Monte Singa section were very high compared those found in modern and sub-recent planktic foraminifera (Wangersky and Joensuu, 1964; Table 2-4; Table 2-6). Elevated levels of Fe and $\mathrm{Mn}$ within biogenic calcite have been found to be linked with diagenetic alteration (Brand and Veizer, 1980; Denison et al., 1994). Levels of Mn higher than 75 ppm and Fe levels higher than $300 \mathrm{ppm}$ can be indicative of diagenetically altered calcite. The concentrations of $\mathrm{Fe}$ and $\mathrm{Mn}$ in the foraminiferal calcite within the four samples from the Monte Singa section had respective ranges of 522 to $717 \mathrm{ppm}$ and 544 to $767 \mathrm{ppm}$ (Table $2-4$; Table 2-6). Although these levels are very high they are not representative of the trace element composition of the foraminiferal calcite and are more a reflection of $\mathrm{Fe}$ and $\mathrm{Mn}$ oxyhydroxide coatings on the foraminiferal calcite (McArthur, 1994). Although the samples were preleached before dissolution and dissolved in acetic acid to minimize contamination from the terrigenous components, there was a significant amount of iron oxide detritus within the solution after dissolution of the foraminiferal calcite. The solutions were centrifuged to minimize the incorporation of this phase in the ICP analysis. However, the dissolution method did not completely exclude this contaminating phase. Subsequent, detailed analysis with an SEM equipped with an Energy Dispersive (EDS) Xray analyzer (LINK eXL LZ4) (Carleton University Scanning Electron Microscope Facilities) of cross sections of foraminiferal calcite indicated undetectable levels of $\mathrm{Mn}$ and very low levels of Fe, which confirmed that the levels were unnaturally high in the ICP analysis.

$\mathrm{The} \mathrm{Mg} / \mathrm{Ca}$ ratios in the planktic foraminiferal calcite of the four samples from the Monte Singa section have values that are within the range of $\mathrm{Mg} / \mathrm{Ca}$ levels found in recent and subrecent planktic foraminifera (Table 2-4; Table 2-6). The typical range of reported 
$\mathrm{Mg} / \mathrm{Ca}$ values is 2.5 to $7 \times 10^{-3}$ which is commensurate with the values from Monte Singa that range from 3.5 to $6.7 \times 10^{-3}$ (Savin and Douglas, 1973; Bender et al., 1975; Lorens et al., 1977; Graham et al., 1982; Delaney et al., 1985; Rosenthal and Boyle, 1993; Puechmaille, 1994; Nürnberg et al., 1996). Since there is no increase or decrease in the $\mathrm{Mg} / \mathrm{Ca}$ ratios relative to modern planktic foraminifera, and since such changes are indicative of diagenetic alteration (Brand and Veizer, 1980; Marshall, 1992), it appears that the $\mathrm{Mg} / \mathrm{Ca}$ ratios of foraminiferal calcite from the Monte Singa section have remained unaltered.

The $\delta^{18} \mathrm{O} \%$ and $\delta^{13} \mathrm{C} \%$ o (PDB) levels of the foraminiferal calcite from the Monte Singa section varied considerably (Table 2-6). The values from SN7 and SN8 match closely the other stable isotope values previously reported from the Monte Singa section (Gudjonsson, 1987; $\delta^{18} \mathrm{O} \%$ (PDB) -0.39 to -2.39 and $\delta^{13} \mathrm{C} \%$ (PDB) 0.27 to 1.64 ) and other sections of the Trubi (Müller, 1993; De Visser et al., 1989). The other two samples SN2 and SN3 have lower $\delta^{18} \mathrm{O} \% o$ and $\delta^{13} \mathrm{C} \%$ (PDB) levels suggesting that these samples may be slightly altered since they are out of the previously reported ranges.

The $\mathrm{Sr} / \mathrm{Ca}$ level in biogenic carbonates is dictated potentially by biogenic discrimination and the $\mathrm{Sr} / \mathrm{Ca}$ composition of seawater, temperature and rate of precipitation (Carpenter et al., 1991; McArthur, 1994). Levels of Sr/Ca within biogenic carbonates which are lower than in their modern equivalents are an indication of alteration, as recrystallization tends to discriminate against the reincorporation of strontium in abiotic calcite (Matter et al., 1975; Veizer, 1983; McArthur, 1994). The Sr/Ca levels within the foraminifera from the four samples from the Monte Singa section were closely clustered ranging from 1.4 to $1.5 \times 10^{-3}$ (Table 2-4; Table 2-6). This range of values, which is derived from a collection of planktic foraminiferal species is within the reported ranges of recent and older planktic foraminifera (last $80 \mathrm{Ma}$ ) which typically range from 1.1 to 1.8 x10-3 (Odum, 1957; Turekian, 1957; Wangersky and Joensuu, 1964; Bender et al., 1975; Lorens et al., 1977; Graham et al., 1982; Delaney et al., 1985; Müller, 1993; Puechmaille, 1994). The close clustering of the $\mathrm{Sr} / \mathrm{Ca}$ values and the general agreement with modern 
and older planktic foraminiferal values indicate that the strontium concentration of the foraminifera from the Monte Singa section has remained substantially unchanged.

The unaltered strontium composition of the planktic foraminifera has also preserved their ${ }^{87} \mathrm{Sr} / 86 \mathrm{Sr}$ isotopic ratios. The mean ${ }^{87} \mathrm{Sr} / 86 \mathrm{Sr}$ value of the twenty-four analyses from the lower Monte Singa section (the base of our section is less than $10 \mathrm{~m}$ above the Miocene/Pliocene boundary) is 0.709052 which gives an age of $4.9 \mathrm{Ma}(5.4-3.7 \mathrm{Ma}$ $(2 \sigma))$ using the curve of Farrell et al. (1995) (Table 2-1). This age, based on the planktic foraminifera that were dissolved in acetic acid, is consistent with the biostratigraphic (base of the Zanclean biozone) and magnetostratigraphic determinations previously carried out on the section and the Trubi in general (Miocene/Pliocene boundary at Monte Singa 4.83 Ma; Gudjonsson, 1987; and see Hilgen and Langereis (1993) for a full discussion).

In summary, the planktic foraminiferal calcite from the four samples analyzed from the Monte Singa section have retained their original isotopic and trace element composition.

\section{Coccolith Alteration}

The contaminating fraction within the limestone and marls from the Monte Singa and the Precariti sections that affected our previous results was the coccolith fraction. Examination of the coccoliths with an SEM revealed a wide range of preservation ranging from well preserved to highly dissolved and overgrown (Plate 2-1; Plate 2-2). The trace element geochemistry of the coccolith fraction also indicates that this fraction is diagenetically altered (Fig. 2-6; Table 2-4; Table 2-6). Although there is not nearly as much background research on the trace chemical makeup of coccoliths as with planktic foraminifera, there are several studies that allow a comparison and judgement on the degree of coccolith alteration to be made.

The coccolith forming algae, like planktic foraminifera, discriminate against the incorporation of $\mathrm{Mg}$ into their calcite crystal lattice. The coccoliths, therefore, are composed of low magnesium calcite with $\mathrm{Sr}$ and $\mathrm{Mg}$ concentrations that are very similar to 
that of planktic foraminifera (Milliman, 1974; Matter et al., 1975; Veizer, 1983). This is clearly not the case in the samples from the Monte Singa section where the coccoliths have elevated ratios of both $\mathrm{Sr} / \mathrm{Ca}$ and $\mathrm{Mg} / \mathrm{Ca}$ in comparison to the planktic foraminifera Fig. 26; Table 2-4; Table 2-6). The coccoliths have $\mathrm{Sr} / \mathrm{Ca}$ ratios that are approximately $8.0 \times 10^{-4}$ larger than the planktic foraminifera. Additionally, they also have $\mathrm{Mg} / \mathrm{Ca}$ ratios several orders of magnitude larger suggesting some form of diagenetic alteration. Observations obtained using the SEM indicate overgrowths of the coccoliths that dramatically altered the trace element chemistry (Plates 2-1, 2-2).

The composition of calcite overgrowths is apparently determined by the $\mathrm{Mg}^{2}+$ to $\mathrm{Ca}^{2+}$ concentration ratio in the precipitating solution (Mucci and Morse, 1982) and the amount of $\mathrm{Sr}^{2+}$ incorporated in the overgrowth is dependant on the $\mathrm{MgCO}_{3}$ content of the precipitate (Mucci and Morse, 1982). The incorporation of $\mathrm{Sr}^{2+}$ in the calcite lattice may serve to relieve some of the stress caused by the incorporation of $\mathrm{Mg}^{2+}$. The levels of $\mathrm{Mg}$ in the coccoliths and overgrowths from the Monte Singa section are within the compositional realm of low Mg calcite (Veizer, 1983), although the levels are higher than the unaltered foraminifera (Fig. 2-6; Table 2-4; Table 2-6). The levels of $\mathrm{Mg}$ in the coccoliths (4-5000 ppm) are much higher than the highest values reported (2000 ppm) from the pelagic sediments in the sections from the Shatsky rise in the northwest Pacific by Matter et al.(1975) and are also much higher than the values reported by Elderfield et al. (1982) from Ontong Java Plateau (maximum value $\mathrm{Mg} / \mathrm{Ca}$ of $4.37 \times 10^{-3}$ ). Dissolution of the surrounding sediment and then the reincorporation in cements or overgrowths discriminates against the inclusion of $\mathrm{Sr}$, which has been used to explain the decrease with depth of $\mathrm{Sr}$ content in recrystalized calcareous fossils and the increases in porewater $\mathrm{Sr}$ (Manheim and Sayles, 1971; Sayles et al., 1974; Matter et al, 1975; Elderfield et al., 1982). The elevated levels found in the overgrown coccoliths from the Monte Singa section suggest higher pore $\mathrm{Mg}$ and $\mathrm{Sr}$ concentrations than would be normally available from dissolution of the surrounding sediment and indicates the introduction of foreign ionic 
species into the porewaters. Some of the $\mathrm{Mg}$ on the overgrowths could be attributed to dolomite, although during SEM examination only one isolated rhomb was found and X-ray diffraction analysis of the sediment revealed no presence of dolomite (Neugebauer, 1974; Matter et al, 1975).

$\mathrm{The} \mathrm{Na} / \mathrm{Ca}$ levels in the coccoliths were lower than the values in the planktic foraminifera (Fig. 2-6; Table 2-4; Table 2-6). Assuming that the normal level of $\mathrm{Na}$ for the coccoliths is within the range for planktic foraminifera, the lower values could indicate as mentioned previously, abiotic overgrowth formation which contains less $\mathrm{Na}$ than biogenic precipitates.

The $\mathrm{Fe} / \mathrm{Ca}$ and $\mathrm{Mn} / \mathrm{Ca}$ levels were also higher in the coccoliths than in the planktic foraminifera and much of this $\mathrm{Fe}$ and $\mathrm{Mn}$ must be in the form of oxyhydroxide coatings on the coccoliths (Fig. 2-6; Table 2-4; Table 2-6). No preleaching was done on the coccolith samples before dissolution for ICP analysis. The solution after dissolution, as with the foraminifera, had a considerable amount of suspended Fe oxides which settled out of suspension with centrifuging. Therefore, the amount that was actually part of the coccolith crystal lattice is difficult to determine.

The $\delta^{18} \mathrm{O} \%$ and $\delta^{13} \mathrm{C} \%$ (PDB) values from the coccoliths are all positive which contrasts with the predominantly negative values of planktic foraminifera (Fig. 2-6; Table 2-6). Since the coccolith calcite is precipitated in isotopic equilibrium with seawater the $\delta^{18} \mathrm{O} \%$ and $\delta^{13} \mathrm{C} \%$ (PDB) values should be in close agreement with the planktic foraminifera data (McIntyre, 1967; Douglas and Savin, 1975; Margolis et. al., 1975; Anderson and Steinmetz, 1981; Czerniakowski et al., 1984). The contrast between the foraminifera and coccoliths indicates that the coccoliths have been diagenetically altered from their original $\delta^{18} \mathrm{O} \%$ and $\delta^{13} \mathrm{C} \%$ o(PDB) values.

The ${ }^{87} \mathrm{Sr} /{ }^{86} \mathrm{Sr}$ values from the coccoliths also clearly indicate their alteration (Fig. 2-4; Fig. 2-6; Table 2-2). The coccolith values are significantly lower than the unaltered planktic foraminiferal calcite in both the marl and the limestones from the samples from the 
Monte Singa section. Previous research on the nannoplankton biostratigraphy of the Trubi fm indicated only minor contamination from reworking of older specimens (that may have lower ${ }^{87} \mathrm{Sr} /{ }^{86} \mathrm{Sr}$ ratios), ruling out this as a source of contamination (Rio et al., 1984). Therefore, the lower ${ }^{87} \mathrm{Sr} / 86 \mathrm{Sr}$ ratios in the coccoliths indicate alteration with a source of strontium other than that derived from the dissolution of carbonate grains from within the section. A possible source of less radiogenic strontium, which could cause the lowering of the ${ }^{87} \mathrm{Sr} /{ }^{86} \mathrm{Sr}$ values in the coccoliths, could be that derived from volcanic material. Mafic volcanic and intrusive rocks from ocean basins are characterized by low ${ }^{87} \mathrm{Sr} /{ }^{86} \mathrm{Sr}$ ratios (0.703). Elderfield et al.(1982) and Hawkesworth and Elderfield (1978) reported the presence of volcanic materials at depth that lowered the ${ }^{87} \mathrm{Sr} / 86 \mathrm{Sr}$ values of recrystallized calcites. There is evidence of volcanism during the late Miocene and Pliocene in the Calabria region in southern Italy and in Sicily (see Cita and Colombo, 1979; Savelli, 1988 for full list of locations and types) that could have been a source of volcanic ash for the Trubi fm. However, this does not seem to be a source of less radiogenic strontium since there has been no volcanic material reported in the Trubi fm; X-ray diffraction analysis did not reveal any characteristic minerals (although they may present in undetectable amounts) and the terrigenous component had a very high ${ }^{87} \mathrm{Sr} /{ }^{86} \mathrm{Sr}$ value (the ${ }^{87} \mathrm{Sr} / 86 \mathrm{Sr}$ value might have been dominated by other mineral constituents).

The lower ${ }^{87} \mathrm{Sr} /{ }^{86} \mathrm{Sr}$ ratios could have also been due to the migration of porewaters from an external and probably older source than the Trubi fm. The Sr age of the coccoliths is from 8 to $5.5 \mathrm{Ma}$ (Hodell et al., 1991) suggesting reequilibration with porewaters containing lower ${ }^{87} \mathrm{Sr} / 86 \mathrm{Sr}$ ratios. The ratios from the coccoliths are very similar to the ratios from the lower Messinian evaporites ( 0.70885 to 0.70895$)$ and the underlying Tortonian marls and glauconite sand $(\approx 0.70895)$ reported from various locations around the Mediterranean by Müller and Mueller (1991), and slightly higher than the upper evaporites which range from 0.70885 to $0.70855 .{ }^{87} \mathrm{Sr} / 86 \mathrm{Sr}$ values from the mudrock of the Serravallian - Tortonian unit from the Stignano Section (see Patterson et al., 1995) 
which is in the same area as the Monte Singa section are also low at 0.70887 and could also be a source for the lower ratios. The Messinian evaporite ${ }^{87} \mathrm{Sr} / 86 \mathrm{Sr}$ values are in very close agreement with the values from the coccoliths and could be a potential source for the less radiogenic Sr. However, there are no evaporites present in the immediate vicinity although they do typically underlie the Messinan fanconglomerates in other locations. A similar model of diagenetic alteration of the original ${ }^{87} \mathrm{Sr} /{ }^{86} \mathrm{Sr}$ signal in Paleogene carbonate samples to less radiogenic values by the influx of brines derived from older evaporite deposits was proposed by Denison et al.(1993).

\section{Porewater Composition and Diagenetic Model}

The porewater composition of the samples from the Monte Singa and the Eraclea Minoa sections displayed distinctly different chemical and isotopic compositions (Fig. 2-7; Table 2-3; Table 2-5; Table 2-6). The porewaters in the Monte Singa section were characterized by high ${ }^{87} \mathrm{Sr} /{ }^{86} \mathrm{Sr}$ ratios (Table $2-3$ ). The $\mathrm{Na} / \mathrm{Ca}$ and $\mathrm{Sr} / \mathrm{Ca}$ values were higher than modern seawater values and the $\mathrm{Mg} / \mathrm{Ca}$ values were lower. The Eraclea Minoa samples displayed a distinctly different pattern with lower ${ }^{87} \mathrm{Sr} / 86 \mathrm{Sr}$ values and $\mathrm{Na} / \mathrm{Ca}$ values similar to that of modern seawater. The $\mathrm{Sr} / \mathrm{Ca}$ values were similar to the Monte Singa samples and were all higher than modern seawater. The $\mathrm{Mg} / \mathrm{Ca}$ ratios were scattered but were generally at or above modern seawater (Fig. 2-7; Table 2-3; Table 2-5; Table 2-6).

Porewater evolution in the Monte Singa section appears to have been complex as is the case in continental margin settings which are typified by the rapid sedimentation of organic rich sediments with high proportions of terrigenous silts and clays and biogenic carbonate (Sayles and Manheim, 1975). A possible model, as described in the preceding section, involves the introduction of brine derived from Messinian evaporites into the Trubi fm during dewatering and compaction of the sediments. In light of our results, this may be a plausible explanation for the alteration of the coccoliths to less radiogenic values, for several reasons: 1) The ${ }^{87} \mathrm{Sr} / 86 \mathrm{Sr}$ value of the altered coccoliths is close to the value of the 
Messinian evaporites; 2) The coccolith $\mathrm{Mg} / \mathrm{Ca}$ and $\mathrm{Sr} / \mathrm{Ca}$ ratios are high which suggests precipitation or recrystallization from fluids with high concentrations (brines); 3) The $\mathrm{Sr} / \mathrm{Ca}$ porewater ratio is very close to the ratio reported by Müller and Mueller (1991) for the main salt unit of the lower evaporites; and 4) The $\mathrm{Na} / \mathrm{Ca}$ ratio of the porewaters is orders of magnitude larger than modern seawater, which suggests a brine influence (perhaps halite). We can also account for the coccolith $\mathrm{Sr} / \mathrm{Ca}$ values from the $\mathrm{Sr} / \mathrm{Ca}$ contained in the porewater using a rough calculation. Using a distribution coefficient of 0.13 for the direct precipitation of calcite (Veizer 1983; Moore 1989) the precipitate from the porewaters (mean $\mathrm{Sr} / \mathrm{Ca}=2.7$ ) in the Monte Singa section should be in the order of $3.5 \times 10^{-3}$. If we consider overgrowths comprising 50\% of the coccoliths (see Douglas and Savin, 1975; Matter et al., 1975; Czerniakowski et al., 1984) and the original Sr/Ca unaltered ratio as $1.5 \times 10^{-3}$ (planktic foraminifera) the resulting ratio would be $2.5 \times 10^{-3}$ which agrees with the measured $\mathrm{Sr} / \mathrm{Ca}$ ratios in the coccoliths. The lower levels of $\mathrm{Mg} / \mathrm{Ca}$ in the porewaters relative to modern seawater can be explained by the increased concentration found in the coccoliths (Table 2-6). The dramatic increase in the ${ }^{87} \mathrm{Sr} / 86 \mathrm{Sr}$ ratios of the porewaters can be ascribed to the alteration of the terrigenous fraction (i.e. feldspars to kaolinite, or isotopic homogenization between clays and porewaters; Clauer et al., 1975). The weathering of the feldspars to kaolinite with their higher ${ }^{87} \mathrm{Sr} /{ }^{86} \mathrm{Sr}$ ratios could release a significant amount of $\mathrm{Sr}$ and $\mathrm{Na}$, causing increases in the ${ }^{87} \mathrm{Sr} / 86 \mathrm{Sr}$ ratios of porewaters and may have produced the direct relationships observed between $\mathrm{Na} / \mathrm{Ca}$ and $\mathrm{Sr} / \mathrm{Ca}$.

The porewaters in the Eraclea Minoa section are dramatically different both in their trace chemistry and in their ${ }^{87} \mathrm{Sr} / 86 \mathrm{Sr}$ ratios which reflect a different diagenetic pathway. The samples from the Eraclea Minoa are more indurated and cemented as they did not disaggregate as easily as the samples from the Monte Singa or the Precariti sections. The porewater and the foraminiferal calcite both had ${ }^{87} \mathrm{Sr} /{ }^{86} \mathrm{Sr}$ ratios that were equivalent considering analytical uncertainty, which suggests that the $\mathrm{Sr}$ isotopic composition of the units was unchanged or had been homogenized during pressure solution and 
recrystallization (Elderfield et al., 1982). The porewater $\mathrm{Na} / \mathrm{Ca}$ levels within the Eraclea Minoa section were slightly lower than modern seawater, which is in contrast to the Monte Singa section which had much higher levels (Table 2-6; Fig. 2-7). The $\mathrm{Sr} / \mathrm{Ca}$ levels were also higher and had approximately the same distribution as that of the Monte Singa section. These contrasting elements indicate the unique diagenetic history of the Monte Singa and Precariti sections. The Eraclea Minoa section was probably indurated and cemented during burial, reducing permeability and creating a relatively closed system. In contrast, the Monte Singa section which was less indurated, was a relatively open system subject to increased weathering and alteration in the burial and subsequent subaerial realm.

\section{Contamination of Original Precariti Results}

The contaminating effect on the ${ }^{87} \mathrm{Sr} / 86 \mathrm{Sr}$ signal of the planktic foraminifera by coccolith carbonate is clearly evident. By considering ${ }^{87} \mathrm{Sr} / 86 \mathrm{Sr}$ ratios in the coccoliths we can account for the lower ${ }^{87} \mathrm{Sr} / 86 \mathrm{Sr}$ values in the marls that were found in the original Precariti section. Using a two-component mixing equation with the mean coccolith and foraminifera ${ }^{87} \mathrm{Sr} /{ }^{86} \mathrm{Sr}$ values in the marls and the limestones and their respective concentrations as the two end-members we can account for our original cyclical signal in the Precariti section (Fig. 2-8; Table 2-2; Table 2-7). Assuming a constant contamination level in both lithologies the required $2 \times 10^{-5}$ change in the ${ }^{87} \mathrm{Sr} /{ }^{86} \mathrm{Sr}$ can be reached with $18 \%$ coccolith contamination in both the limestone and the marls (Fig. 2-8). The greater contamination potential in the marls is apparently due to the lower ratios in the coccoliths found in the marls. Infillings of sediment within the foraminiferal tests were abundant when thin sections were examined with an SEM (Plate 2). It would not require a significant amount of infills to cause the $18 \%$ contamination for the $2 \times 10^{-5}$ change in the ${ }^{87} \mathrm{Sr} /{ }^{86} \mathrm{Sr}$ signal and there is no reason to believe that the degree of infilling would change between the marl and limestone lithologies. Careful cleaning by crushing and preleaching 
would eliminate the potential contamination, and this procedure was followed in the Monte Singa samples.

The bulk rock values both in the limestones and the marls are dominated by the $\mathrm{Sr}$ concentration from the coccoliths which have concentrations 1.12 and $1.02 \mathrm{ppt}$ in the marls and 0.72 and $0.95 \mathrm{ppt}$ in the limestones (Table 2-7). The weight percent of coccoliths in the carbonate fraction within the marls had a mean of $86 \%$ and the limestones were higher at $94 \%$. When considering the abundance of the coccoliths within the marls and the limestones, the lower ratios in the bulk rock samples are due to the lower ${ }^{87} \mathrm{Sr} / 86 \mathrm{Sr}$ values of the coccoliths themselves. These results have very important implications for the use of bulk rock for Sr isotope stratigraphy and emphasize the need for careful selection of individual unaltered components.

\section{CONCLUSIONS}

The diagenetic alteration of the various constituents of the marl and limestone lithologies from the Monte Singa section was determined through detailed trace element and isotopic analysis. This information allowed the assessment of the original ${ }^{87} \mathrm{Sr} / 86 \mathrm{Sr}$ signal that alternated with the marl and limestone lithologies in the Precariti section that we had originally thought was due to precessionally controlled changes in precipitation and runoff into the Mediterranaean during the Pliocene. The ${ }^{87} \mathrm{Sr} /{ }^{86} \mathrm{Sr}$ isotope methodology did not prove to be a useful proxy in such a large restricted basin.

This research emphasizes the care that must be taken in the selection and preparation of sample material for ${ }^{87} \mathrm{Sr} /{ }^{86} \mathrm{Sr}$ determinations. The lack of consideration of differential diagenetic alteration of the various constituents lead to erroneous results in the Precariti section. The contamination that resulted from the inclusion of the altered coccoliths with the planktic foraminifera in the ${ }^{87} \mathrm{Sr} / 86 \mathrm{Sr}$ determinations was not exceptionally great. The difference in the mean ratios was just outside analytical uncertainty at $2 \times 10^{-5}$. However, 
with the increased analytical precision and with the development of higher resolution ${ }^{87} \mathrm{Sr} /{ }^{86} \mathrm{Sr}$ curves, subtle diagenesis becomes more and more important (McArthur, 1994).

The use of bulk samples from Monte Singa and the Precariti sections for strontium isotope stratigraphy would yield very erroneous values. Sample SN2 which exhibited the largest difference between the ${ }^{87} \mathrm{Sr} / 86 \mathrm{Sr}$ ratio of the bulk sample and the foraminifera would have yielded a value $1 \times 10^{-4}$ lower. This emphasizes the heterogeneity of the ${ }^{87} \mathrm{Sr} / 86 \mathrm{Sr}$ distribution within the limestone and marl samples and the need for detailed examination for diagenetic alteration before bulk samples are used.

The heterogeneity of the trace element and isotopic composition of limestones and marls also emphasizes the complexity of the diagenetic history of sediments deposited in a continental margin environment with a high proportion of terrigenous material (Sayles and Manheim, 1975).

\section{ACKNOWLEDGEMENTS}

This research was supported by Natural Sciences and Engineering Research Council of Canada (NSERC) Operating grant to R.T.P., a NATO Collaborative Research Grant to R.T.P. and W.C. and research funds provided by J.B. 


\section{REFERENCES}

Anderson T.F. and Steinmetz J.C. (1981) Isotopic and biostratigraphic records of calcareous nannofossils in a Pleistocene core. Nature 294, 741-744.

Barrier P. and Montenat C. (1987) Essai de quantification des mouvements verticaux pliopleistocènes dans le Detroit de Messine (Italie). Notes and Memoires, Total Comp. Franc. Petr. 21, 73-79.

Bates N.R. and Brand U. (1991) Environmental and physiological influences on isotopic and elemental compositions of brachiopod shell calcite: Implications for the isotopic evolution of Paleozoic oceans, Chem.Geol. (Isotope Geoscience Section) 94, 6778.

Bender M.L., Lorens R.B., and Williams D.F. (1975) Sodium, magnesium and strontium in the tests of planktonic foraminifera. Micropaleontology 21, 448-459.

Brand U. and Veizer J. (1980) Chemical diagenesis of a multicomponent carbonate system-1: Trace elements, J. Sediment. Petrol. 50, 1219-1236.

Brass G.W. (1976) The variation of the marine ${ }^{87} \mathrm{Sr} /{ }^{86} \mathrm{Sr}$ ratio during Phanerozoic time: interpretation using a flux model. Geochim. Cosmochim. Acta 40, 721-730.

Bryant J.D., Jones D.S., and Mueller P.A. (1995) Influence of freshwater flux on $87 \mathrm{Sr} / 86 \mathrm{Sr}$ chronostratigraphy in marginal marine environments and dating of vertebrate and invertebrate faunas. J. Paleont. 69,1-6. 
Burke W.H., Denison R.E., Hetherington E.A., Koepnick R.B., Nelson H.F., and Otto J.B. (1982) Variation of seawater ${ }^{87} \mathrm{Sr} / 86 \mathrm{Sr}$ through Phanerozoic time. Geology 10, 516-519.

Capo R.C. and DePaolo D.J. (1990) Seawater strontium isotopic variations: 2.5 Ma to the present. Science 249, 51-55.

Carpenter S.J., Lohmann K.C., Holden P., Walter L.M., and Huston T.J. (1991) $\delta^{18}$ O values, ${ }^{87} \mathrm{Sr} /{ }^{86} \mathrm{Sr}$ and $\mathrm{Sr} / \mathrm{Mg}$ ratios of Late Devonian abiotic marine calcite: Implications for the composition of ancient seawater. Geochim. Cosmochim. Acta 55, 1991-2010.

Cavazza W., Blenkinsop J., DeCelles P., Patterson R.T., and Reinhardt E.G.(1997) Stratigrafia e sedimentologia della sequenza sedimentaria oligocenico-quaternaria del bacino calabro-ionico, Bollettino della Societa' Geologica Italiana, in press.

Cavazza W. and Dahl J. (1990) Note on the temporal relationships between precipitation of authigenic minerals and sandstone compaction. Sed. Geology 69, 37-44.

Cita M.B. (1982) The Messinian salinity crisis in the Mediterranean. A review in AlpineMediterranean Geodynamics: (eds. Berckhemer H. and Hsü K) pp. 113-140. American Geophysical Union.

Cita M.B. and Colombo L. (1979) Sedimentation in the latest Messinian at Capo Rossello (Sicily). Sedimentology 26, 497-522. 
Clauer N., Hoffert M., Grimaud D., and Millot G. (1975) Composition isotopique du strontium d'eaux interstitielles extraites de sédiments récents: un argument en faveur de l'homogénéisation isotopique des minéraux argileux. Geochim. Cosmochim. Acta 39, 1579-1582.

Clemens S.C., Farrell J.W., and Gromet L.P. (1993) Synchronous changes in seawater strontium isotope composition and global climate. Nature 363, 607.

Clemens S.C., Gromet L.P., and Farrell J.W. (1995) Artefacts in Sr isotope records. Nature 373, 201.

Czerniakowski L.A., Lohmann K.C., and Wilson J.L. (1984) Closed-system marine burial diagenesis: isotopic data from the Austin Chalk and its components. Sedimentology 31, 863-877.

DeCelles P.G. and Cavazza W. (1995) Upper Messinian conglomerates in Calabria, southern Italy: response to orogenic edge adjustment following Mediterranea sealevel changes. Geology 23, 775-778.

Delaney M.L., Bé A.W.H., and Boyle E.A. (1985) Li, Sr, Mg, and $\mathrm{Na}$ in foraminiferal calcite shells from laboratory culture, sediment traps and sediment cores. Geochim. Cosmochim. Acta 49, 1327-1341.

DePaolo D.J. and Ingram B.L. (1985) High resolution stratigraphy with strontium isotopes. Science 227, 938-941. 
De Visser J.P., Ebbing J.H.J., Gudjonsson L., Hilgen F.J., Jorissen F.J., Verhallen P.J.J.M., and Zevenboom D. (1989) The origin of rhythmic bedding in the Pliocence Trubi Formation of Sicily, southern Italy. Palaeogeogr., Palaeoclimatol., Palaeoecol. 69, 45-66.

Denison R.E, Koepnick R.B., Fletcher A., Dahl D.A., and Baker M.C. (1993) Reevaluation of early Oligocene, Eocene, and Paleocene seawater strontium isotope ratios using outcrop samples from the U.S. Gulf Coast. Paleoceanography 8, 101126.

Denison R.E., Koepnick R.B., Burke W.H., Hetherington E.A., and Fletcher A. (1994) Construction of the Mississipian, Pennsylvanian and Permian seawater ${ }^{87} \mathrm{Sr} /{ }^{86} \mathrm{Sr}$ curve. Chemical Geology (Isotope Geoscience Section) 112, 145-167.

Dia A.N., Cohen A.S., O’Nions R.K., and Shackleton N.L.(1992) Seawater Sr isotope variation over the past $300 \mathrm{Kyr}$ and the influence of global climate cycles. Nature 356, 786-788.

Douglas R.G. and Savin S.M. (1975) Oxygen and carbon isotope analyses of Tertiary and Cretaceous microfossils from Shatsky Rise and other sites in the north Pacific ocean. In Initial Reports of the Deep Sea Drilling Project (eds. R.L. Larson et al.) Vol. 32, pp. 509-520. U.S. Government Printing Office.

Elderfield H., Gieskes J.M., Baker P.A., Oldfield R.K., Hawkesworth C.J., and Miller R. (1982) ${ }^{87} \mathrm{Sr} /{ }^{86} \mathrm{Sr}$ and ${ }^{18} \mathrm{O} 16 \mathrm{O}$ ratios, interstitial water chemistry and diagenesis in deep-sea carbonate sediments of the Ontong Java Plateau. Geochem. Cosmochim. Acta 46, 2259-2268. 
Emelyanov E.M. and Shimkus K.M. (1986) Geochemistry and Sedimentology of the Mediterranean Sea: Sedimentology and Petroleum Geology. Reidel, Doredrecht.

Farrell J.W., Clemens S.C., and Gromet L.P. (1995) Improved chronostratigraphic reference curve of late Neogene seawater ${ }^{87} \mathrm{Sr} /{ }^{86} \mathrm{Sr}$. Geology 23, 403-306.

Graham D.W., Bender M.L., Williams D.F., and Keigwin L.D., Jr. (1982) Strontiumcalcium ratios in Cenozoic planktonic foraminifera. Geochim. Cosmochim. Acta 46, 1281-1292.

Gudjonsson L. (1987) Local and global effects on the Early Pliocence Mediterranean stable isotope records. Mar. Micropaleontol. 12, 241-253.

Hawkesworth C.J. and Elderfield H. (1978) The strontium isotope composition of interstitial waters from Sites 245 and 336 DSDP. Earth Planet. Sci. Lett. 40, 423432.

Henderson G.M., O’Nions R.K., and Shackleton N.J. (1993) Sr-isotopes in Quaternary planktonic foraminifera from the Pacific and Indian Oceans, EOS, Abstr. Spring Mtng, 176.

Hilgen F.J. (1987) Sedimentary rhythms and high-resolution chronostratigraphic correlations in the Mediterranean Pliocene. Newsl. Stratigr. 17, 109-127

Hilgen F.J. (1991) Extension of the astronomically calibrated (polarity) timescale to the Miocene/Pliocene boundary. Earth Planet. Sci. Lett. 107, 211-225. 
Hilgen F.J. and Langereis C.G. (1989) Periodicities of $\mathrm{CaCO}_{3}$ cycles in the Pliocence of Sicily: discrepancies with the quasi-periods of the Earth's orbital cycles? Terra Nova 1, 409-415.

Hilgen F.J. and Langereis C.G. (1993) A critical re-evaluation of the Miocene/Pliocene boundary as defined in the Mediterranean. Earth Planet. Sci. Lett.. 118, 167-179.

Hodell D.A., Mead G.A., and Mueller P.A., (1990) Variation in the strontium isotopic composition of seawater ( $8 \mathrm{Ma}$ to present): implications for chemical weathering rates and dissolved fluxes to the oceans. Chem. Geol. 80, 291-307.

Hodell D.A., Mueller, P.A., and Garrido J.R. (1991) Variations in the strontium isotopic composition of seawater during the Neogene. Geology 19, 24-27.

Hsu K.J., Montadert L., Bernoulli D., Cita M.B., Erikson A., Garrison R.E., Kidd R.B., Melieres F., Müller C., and Wright R.H. (1977) History of the Mediterranean salinity crisis. Nature 267, 399-402.

Ingram B.L. and Sloan D. (1992) Strontium isotopic composition of estuarine sediments as paleosalinity-paleoclimate indicator. Science $\mathbf{2 5 5}$, 68-72.

Kitano Y., Okumura M., and Idogaki M. (1975) Incorporation of sodium, chloride, and sulfate with calcium carbonate, Geochem. J. 9, 75-84. 
Krishnaswami S., Trivedi J.R., Sarin M.M, Ramesh R., and Sharma K.K. (1992) Strontium isotopes and rubidium in the Ganga-Brahmaputra river system: weathering in the Himalaya, fluxes to the Bay of Bengal and contributions to the evolution of oceanic ${ }^{87} \mathrm{Sr} / 86 \mathrm{Sr}$ : Earth Planet. Sci. Lett. 109, 243-253.

Land L.S. and Hoops G.K. (1973) Sodium in carbonate sediments and rocks: a possible index to the salinity of diagenetic solutions. Jour. Sed. Petrology 43, 614-617.

Langereis C.G. and Hilgen F.J. (1991) The Rosello composite: a Mediterranean and global reference section for the Early to Late Pliocence: Earth Planet. Sci. Lett. 104, 211225.

Lorens R.B., Williams D.F., and Bender M.L. (1977) The early nonstructural chemical diagenesis of foraminiferal calcite. J. Sedimentary Petrology 47, 1602-1609.

Lourens L.J., Hilgen F.J., Gudjonsson, L., and Zachariasse W.J. (1992) Late Pliocence to early Pleistocene astronomically forced surface productivity and temperature variations in the Mediterranean. Mar. Micropaleontol.. 19, 49-78.

Marshall J.D. (1992) Climatic and oceanographic isotopic signals from the carbonate rock record and their preservation. Geol. Mag. 129, 143-160.

Matter A., Douglas R.G., and Perch-Nielsen K. (1975) Fossil preservation, geochemistry, and diagenesis of pelagic carbonates from Shatsky Rise, northwest Pacific. Init. Rep. Deep Sea drill. Proj. 32, 891-921. 
Manheim F.T. and Sayles F.L. (1971) Interstitial water studies on small core samples, Deep Sea Drilling Project, Leg 8. In Initial Reports of the Deep Sea Drilling Project, (ed. J.I. Tracey Jr. et al.), Vol. 8, pp. 857-869. U.S. Government Printing Office.

Margolis S.V. et al. (1975) Oxygen and carbon isotopes from calcareous nannofossils as paleooceanographic indicators. Science 189, 555-557.

McArthur, J.M. (1991) Stratigraphy with strontium isotopes. Geology Today 7/6, 5i-5iv.

McArthur J.M. (1994) Recent trends in strontium isotope stratigraphy. Terra Nova 6, 331-358.

McArthur J.M., Thirlwall M.F., Gale A.S., Kennedy W.J., Burnett J.A., Mattey D., and Lord A.R. (1993a) Strontium-isotope stratigraphy for the Late Cretaceous: a new curve, based on the English Chalk. In: High Resolution Stratigraphy, (ed. E. Hailwood and R. Kid). Spec. Publ. Geol. Soc. London 70, 195-209.

McArthur J.M., Chen M., Gale A.S., Thirlwall M.F., and Kennedy W.J. (1993b) Strontium-isotope stratigraphy for the Late Cretaceous: direct numerical age calibration of the Sr-isotope curve for the U.S. Western Interior Seaway. Palaeogeogr. Palaeoclim. Palaeoecol. 108, 95-119.

McIntyre, A. (1967) Coccoliths as paleoclimatic indicators of Pleistocene glaciation. Science 158, 1314-1317. 
Miller K.G., Feigenson M.D., Kent D.V., and Olsson R.K. (1988) Oligocene stable isotope $\left({ }^{87} \mathrm{Sr} / 86 \mathrm{Sr}, \delta^{18} \mathrm{O}, \delta^{13} \mathrm{C}\right)$ standard section, DSDP site 522 , Paleoceanography 3, 223-233.

Miller K.G., Feigenson, M.D., and Wright J.D. (1990) Miocene isotope standard section, DSDP site 608: an evaluation of isotope and biostratigraphic resolution. Paleoceanography 5.

Milliman J.D. (1974). Marine Carbonates. Springer-Verlag .

Moore C.H. (1989) Carbonate Diagenesis and Porosity. Elsevier.

Mucci A. and Morse J.W. (1982) The incorporation of $\mathrm{Mg}^{2+}$ and $\mathrm{Sr}^{2+}$ into calcite overgrowths: influences of growth rate and solution composition. Geochim. Cosmochim. Acta 47, 217-233.

Müller D.W. (1993) Pliocene transgression in the western Mediterranean Sea: Strontium isotopes from Cuevas del Almanzora (se Spain). Paleoceanography 8, 127-134.

Müller D.W. and Mueller P.A. (1991) Origin and age of the Mediterranean Messinian evaporites: Implications from Sr isotopes. Earth Planet. Sci. Lett. 107, 1-12.

Neugebauer J. (1974) Some aspects of cementation in chalk. In Pelagic Sediments: on Land and under the Sea (ed. K.J. Hsu and H.C. Jenkyns). Spec. Publs int. Ass. Sediment. Vol. 1, pp. 149-176. Blackwell Scientific Publications. 
Nürnberg D., Buma J., and Hemleben C. (1996) Assessing the reliability of magnesium in foraminiferal calcite as a proxy for water mass temperatures. Geochim. Cosmochim. Acta 60, 803-814.

Odum H.T. (1957) Biogeochemical deposition of strontium. Publications of the Institute of Marine Science 4, 38-114.

Patterson R.T., Blenkinsop J., and Cavazza W. (1995) Planktic foraminiferal biostratigraphy and ${ }^{87} \mathrm{Sr} /{ }^{86} \mathrm{Sr}$ isotopic stratigraphy of the Oligocene-to-Pleistocene sedimentary sequence in the southeastern Calabrian microplate, southern Italy. $J$. Paleont. 69, 7-20.

Palmer M.R. and Edmond J.M. (1989) The strontium isotope budget of the modern ocean. Earth Planet. Sci. Lett. 92, 11-26.

Palmer M.R. and Edmond J.M. (1992) Controls over the strontium isotope composition of river water. Geochim. Cosmochim. Acta 56, 2099-2111.

Pichler T. and Dix G.R. (1996) Hydrothermal venting within a coral reef ecosystem, Ambitle Island, Papua New Guinea. Geology 24, 435-438.

Puechmaille C. (1994) Mg, Sr and Na fluctuations in the tests of modern and recent Globigerina bulloides. Chem. Geol. 112, 147-152.

Popp B.N., Podosek F.A., Brannon J.C., Anderson T.F., and Pier J. (1986) ${ }^{87} \mathrm{Sr} / 86 \mathrm{Sr}$ ratios in Permo-Carboniferous sea water from the analyses of well-preserved brachiopod shells. Geochim. Cosmochim. Acta 50, 1321-1328. 
Rosenthal Y. and Boyle E. (1993) Factors controlling the fluoride content of planktic foraminifera: An evaluation of its paleooceanographic applicability. Geochim. Cosmochim. Acta 57, 335-346.

Richter F.M. and Turekian K.K. (1993) Simple models for the geochemical response of the ocean to climatic and tectonic forcing. Earth Planet. Sci. Lett. 119, 121-131.

Richter F.M., Rowley D.B. and DePaolo D.J. (1992) Sr isotope evolution of seawater: The role of tectonics: Earth Planet. Sci. Lett. 109, 11-23.

Rio D., Sprovieri R. and Raffi I. (1984) Calcareous plankton biostratigraphy and biochronology of the Pliocene - Lower Pleistocene succession of the Capo Rosselo area, Sicily. Mar. Micro. 9, 135-180.

Sayles F.L. and Manheim F.T. (1975) Interstitial solutions and diagenesis in deeply buried marine sediments: results from the Deep Sea Drilling Project. Geochim. Cosmochim. Acta 39, 103-127.

Sayles F.L., Manheim F.T. and Waterman L.S. (1974) Interstitial water studies on small core samples, Leg 15, In Initial Reports of the Deep Sea Drilling Project, (ed. B.C. Heezan, I.D. MacGregor et al.), Vol. 20, pp. 783-804. U.S. Government Printing Office.

Savelli C. (1988) Late Oligocene to Recent episodes of magmatism in and around the Tyrrhenian Sea: implications for the processes of opening in a young inter-arc basin of intra-orogenic (Mediterranean) type. Tectonophysics 146, 163-181. 
Savin S.M. and Douglas R.G. (1973) Stable isotopes and magnesium geochemistry of Recent planktonic foraminifera from the South Pacific. Geol. Soc. Amer. Bull. 84, 2327-2342.

Thunell R., Rio D., Sprovieri R., and Raffi I. (1991) Limestone-marl couplets: origin of the early Pliocene Trubi marls in Calabria, southern Italy. Journ. of Sed. Petrol. 61, 1109-1122.

Turekian K.K. (1957) The significance of variations in the strontium content of deep sea cores: Limnol. Oceanography 2 309-314.

Veizer J. (1983) Trace Elements and Isotopes in Sedimentary Carbonates. In Carbonates: Mineralogy and Chemistry (ed. R.J. Reeder) Vol. 11, Chap. 8, pp. 265-299.

Veizer J., Clayton R.N., and Hinton R.W. (1992) Geochemistry of Precambrian carbonates: IV. Early Paleoproterozoic $(2.250 .25 \mathrm{Ga})$ seawater, Geochim. Cosmochim. Acta 56, 875-885.

Wangersky P.J. and Joensuu O. (1964) Strontium, magnesium and manganese in fossil foraminiferal carbonates. J. Geol. 72, 477-483.

White A.F. (1978) Sodium coprecipitation in calcite and dolomite: Chem. Geol. 26, 6572.

Wickman F.W. (1948) Isotope Ratios: a clue to the age of certain marine sediments, J. Geol. 56, 61-66. 
Zijderveld J.D.A., Hilgen F.J., Langereis C.G., Verhallen P.J.J.M., and Zachariasse W.J. (1991) Integrated magnetostratigraphy and biostratigraphy of the upper Pliocence-lower Pleistocene from the Monte Singa and Crotone areas in Calabria, Italy. Earth Planet. Sci. Lett. 107, 697-714. 
Fig. 2-1. Geological map of southern Italy showing the location of the Monte Singa and Precariti sections (after Cavazza and Dahl, 1990). 


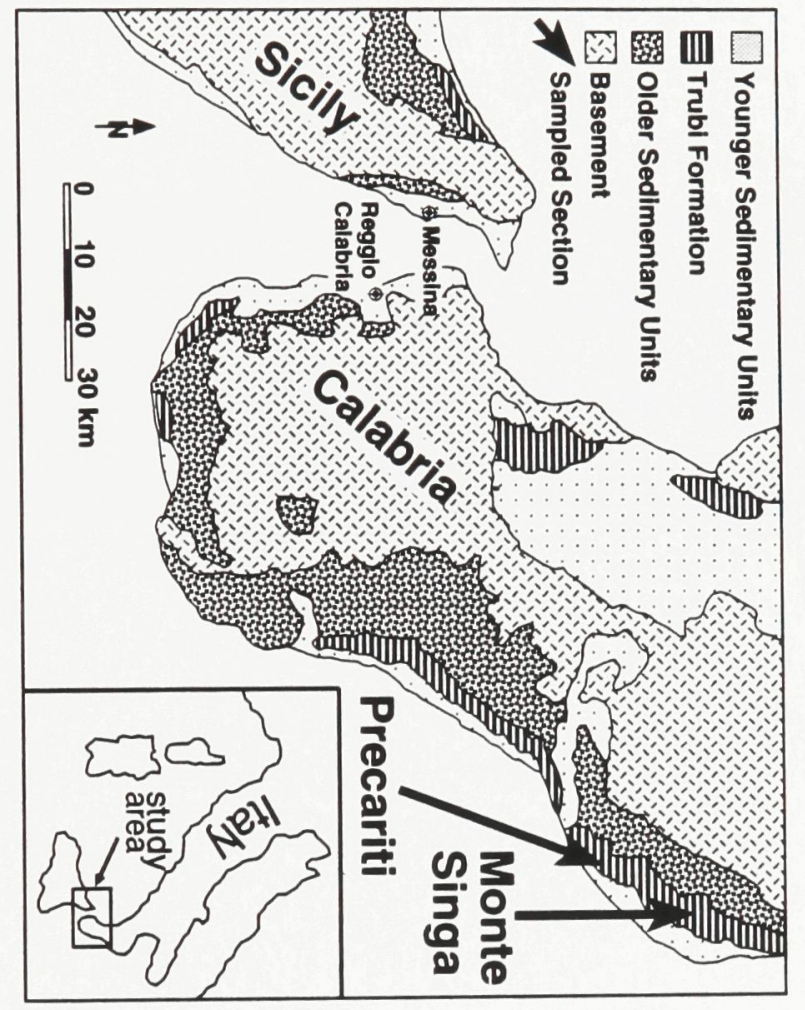


Fig. 2-2. Stratigraphic section from the Precariti location showing the cyclical relationship of the ${ }^{87} \mathrm{Sr} /{ }^{86} \mathrm{Sr}$ values with lithology. The solid line represents the ${ }^{87} \mathrm{Sr} /{ }^{86} \mathrm{Sr}$ results using the $\mathrm{HCl}$ digestion method and no preleaching; the dashed line represents results using the acetic acid digestion method and preleaching. The error bar represents two standard deviations $(2 \sigma)$. 


\section{Precariti Section}

\section{UTM 33627418}

4250661

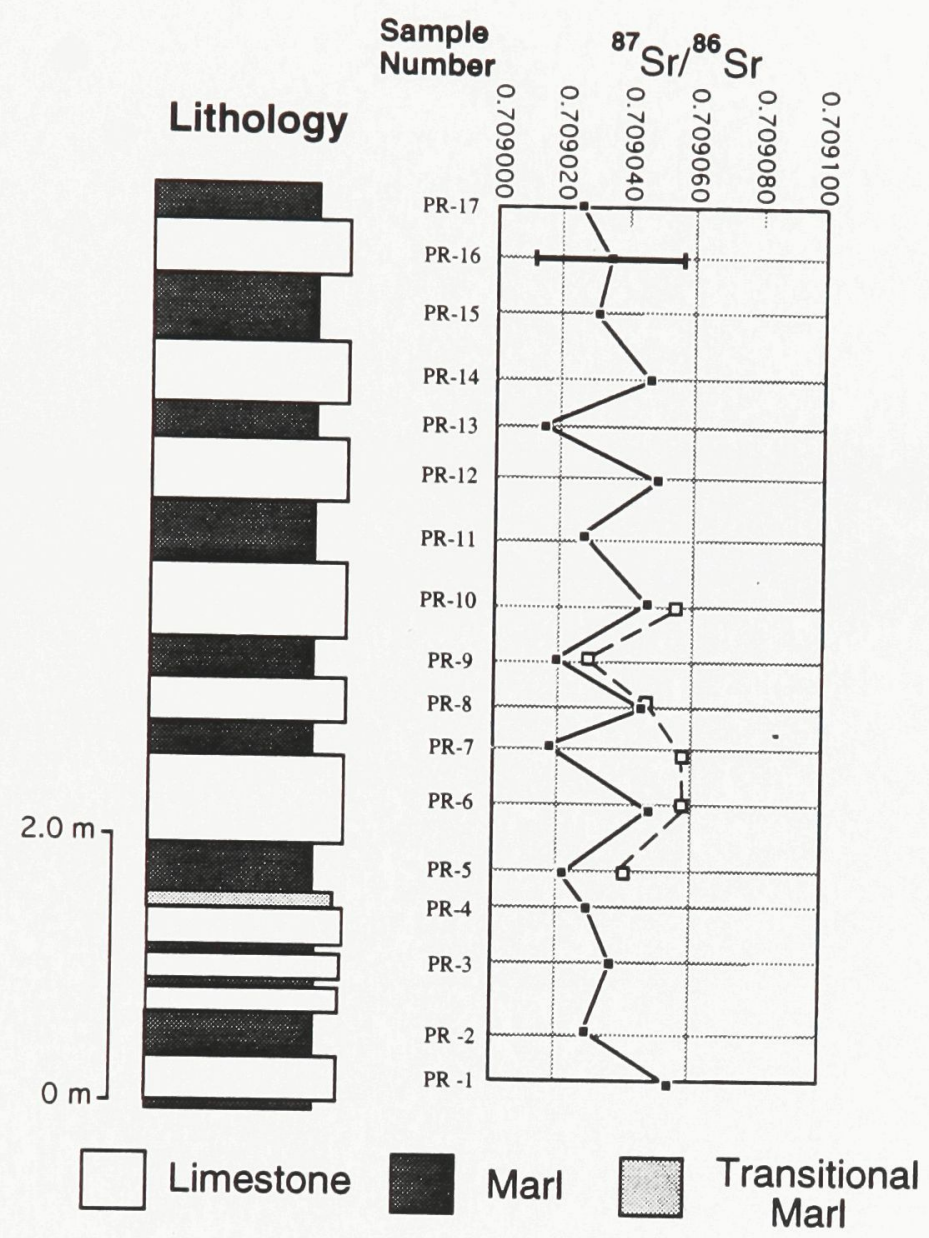


Fig. 2-3. Stratigraphic section from the Monte Singa location showing no relationship of the ${ }^{87} \mathrm{Sr} /{ }^{86} \mathrm{Sr}$ values with lithology. The error bar represents two standard deviations $(2 \sigma)$. 


\section{Monte Singa Section UTM 33629732 \\ 4251486}

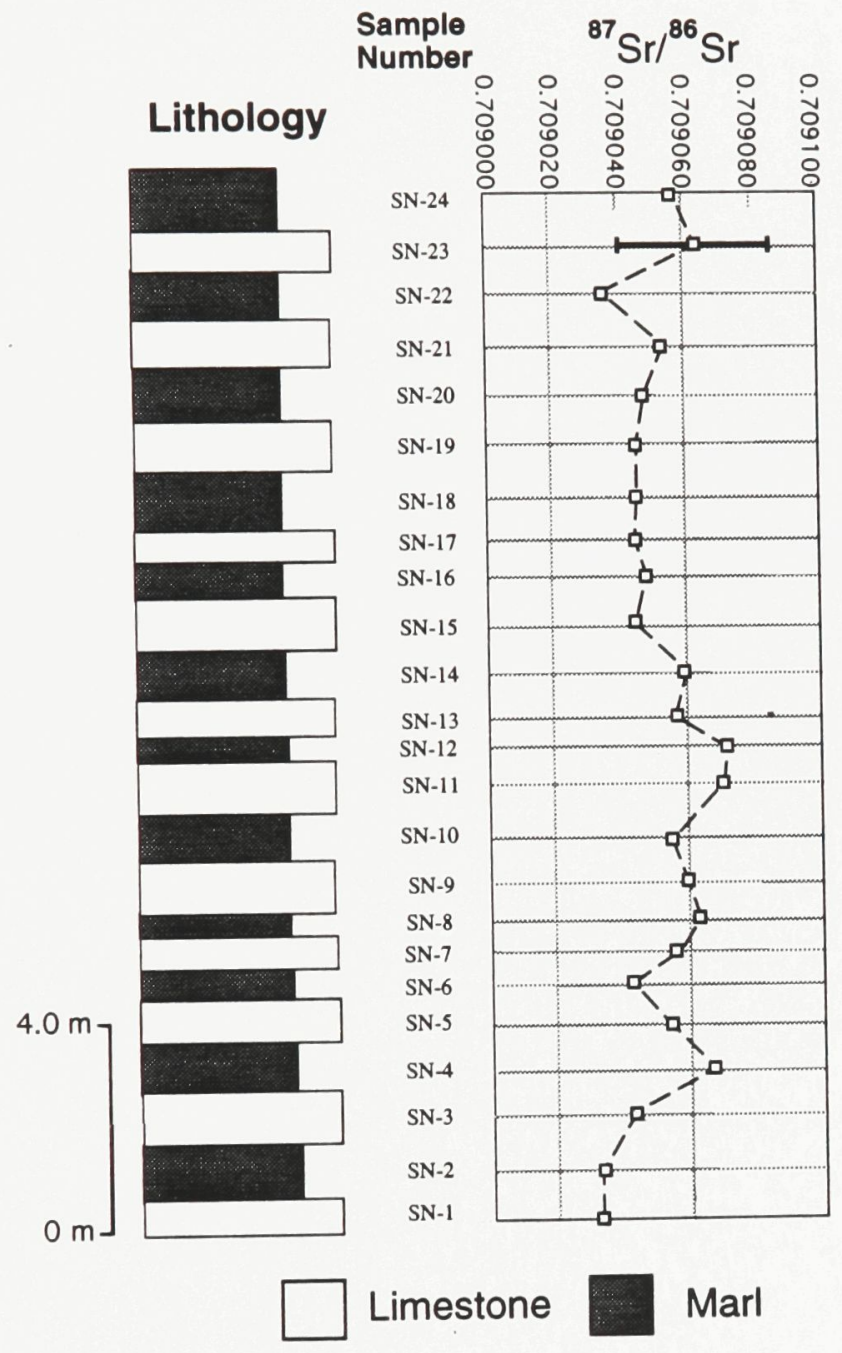


Fig. 2-4. Bar graphs showing the distribution of ${ }^{87} \mathrm{Sr} / 86 \mathrm{Sr}$ values amongst the constituents of the four limestone and marl samples from the Monte Singa section. The error bar represents two standard deviations $(2 \sigma)$. 
SN 2

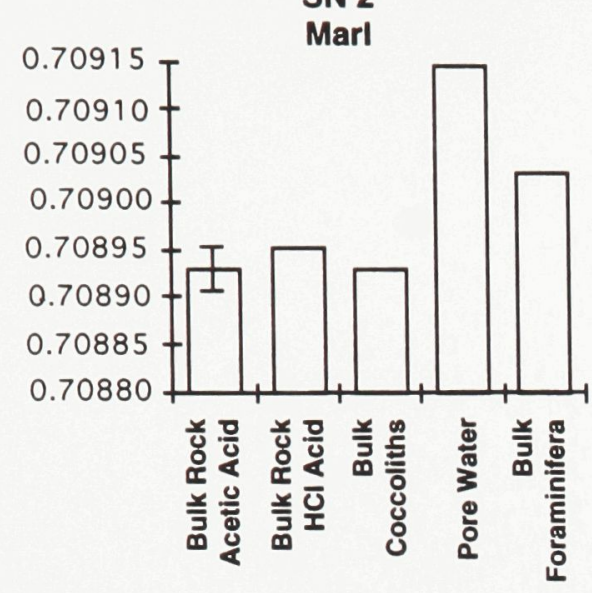

SN 7

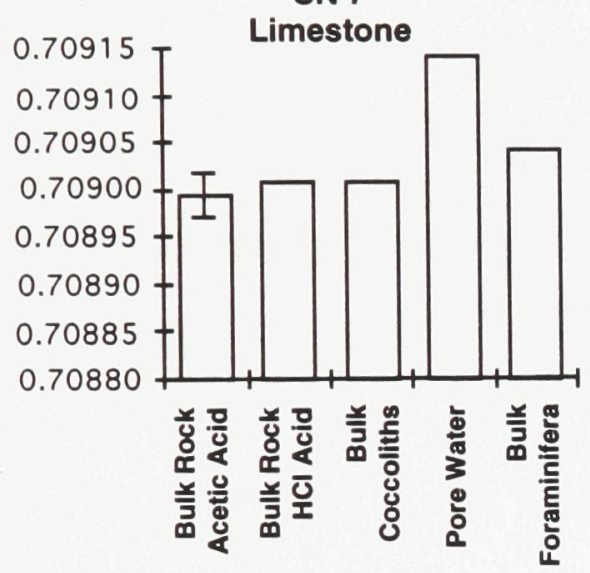

SN 3

Limestone

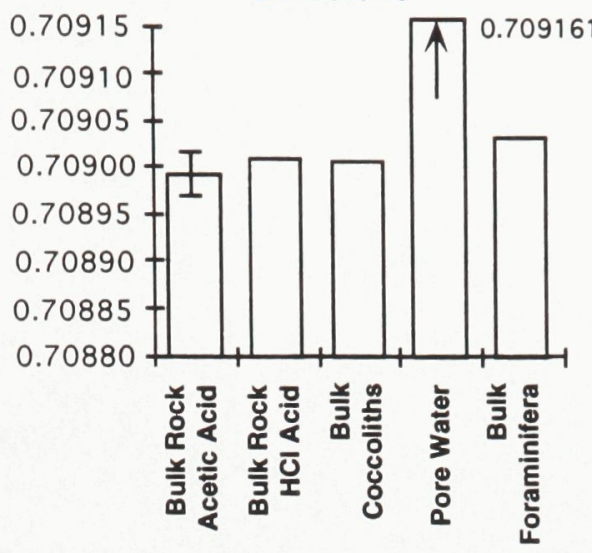

SN 8

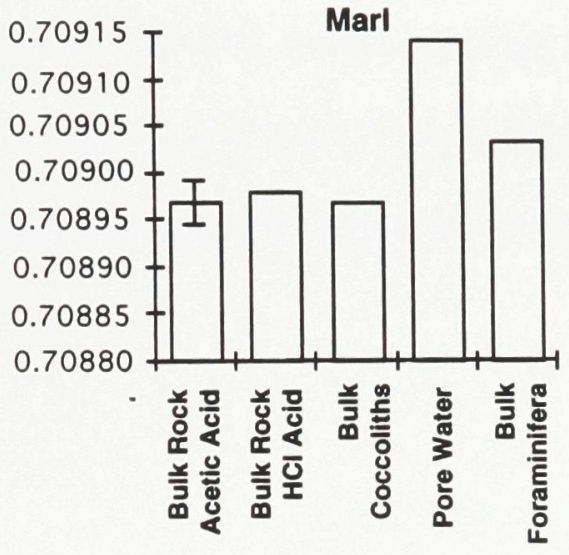

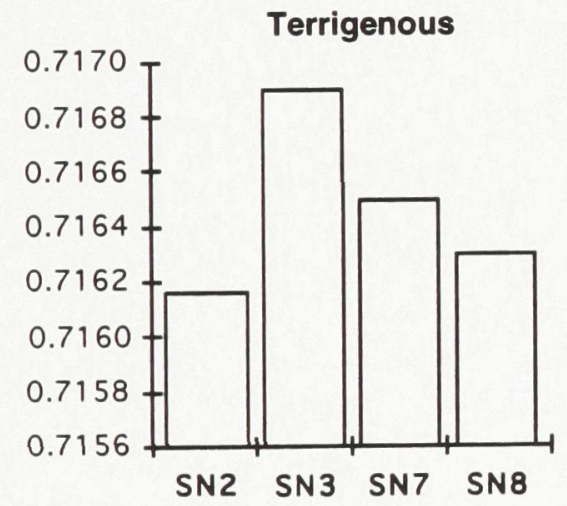


Fig. 2-5. Bivariate plot of porewater and foraminifera ${ }^{87} \mathrm{Sr} / 86 \mathrm{Sr}$ values from the Monte Singa section from southern Italy and the Eraclea Minoa section from Sicily. Note the separation of values from the upper and lower Monte Singa and the Eraclea Minoa sections. The error bar represents two standard deviations $(2 \sigma)$. 


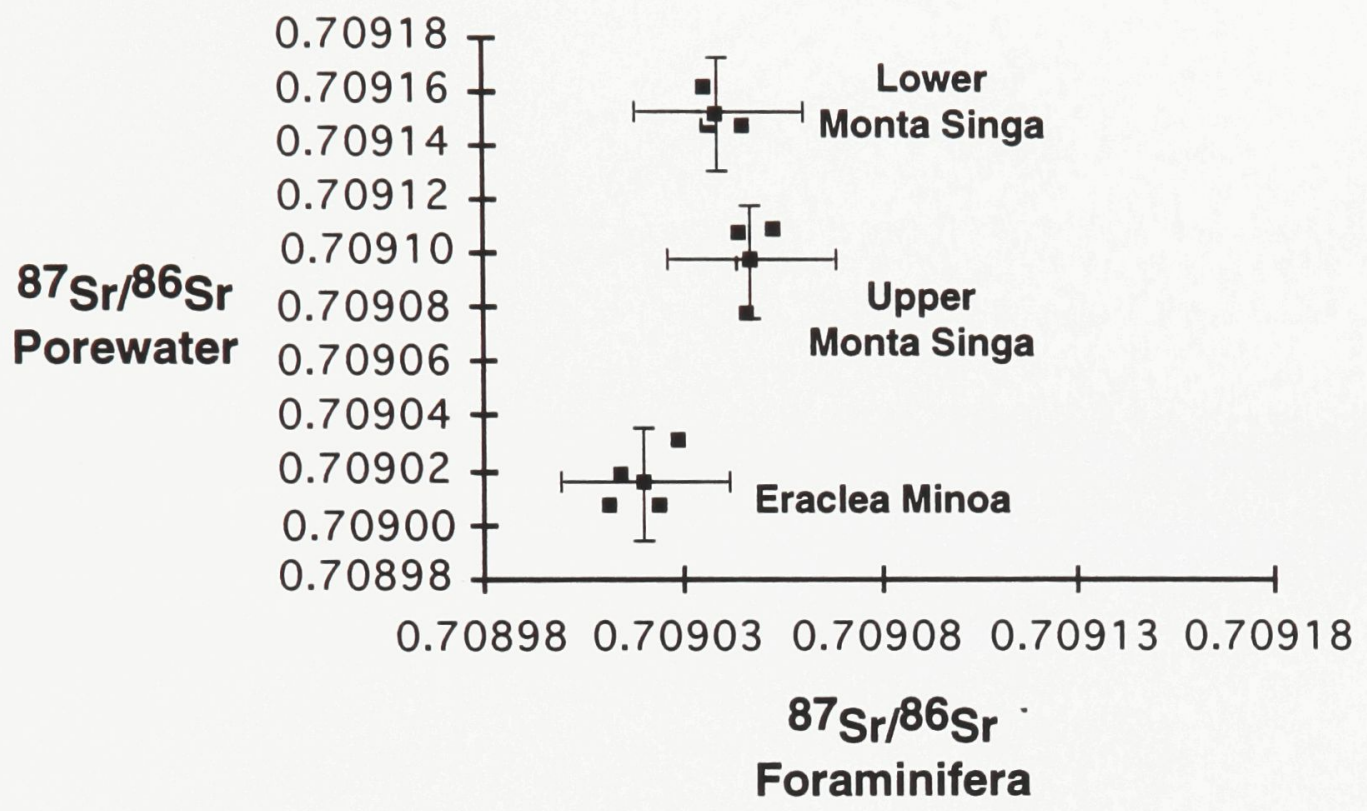


Fig. 2-6. Bivariate plots of the trace element and isotopic compositions of the foraminifera and coccoliths from the four samples $(\mathrm{SN} 2,3,7,8)$ from the Monte Singa Section. Note the clear separation of the coccolith and foraminiferal values. 

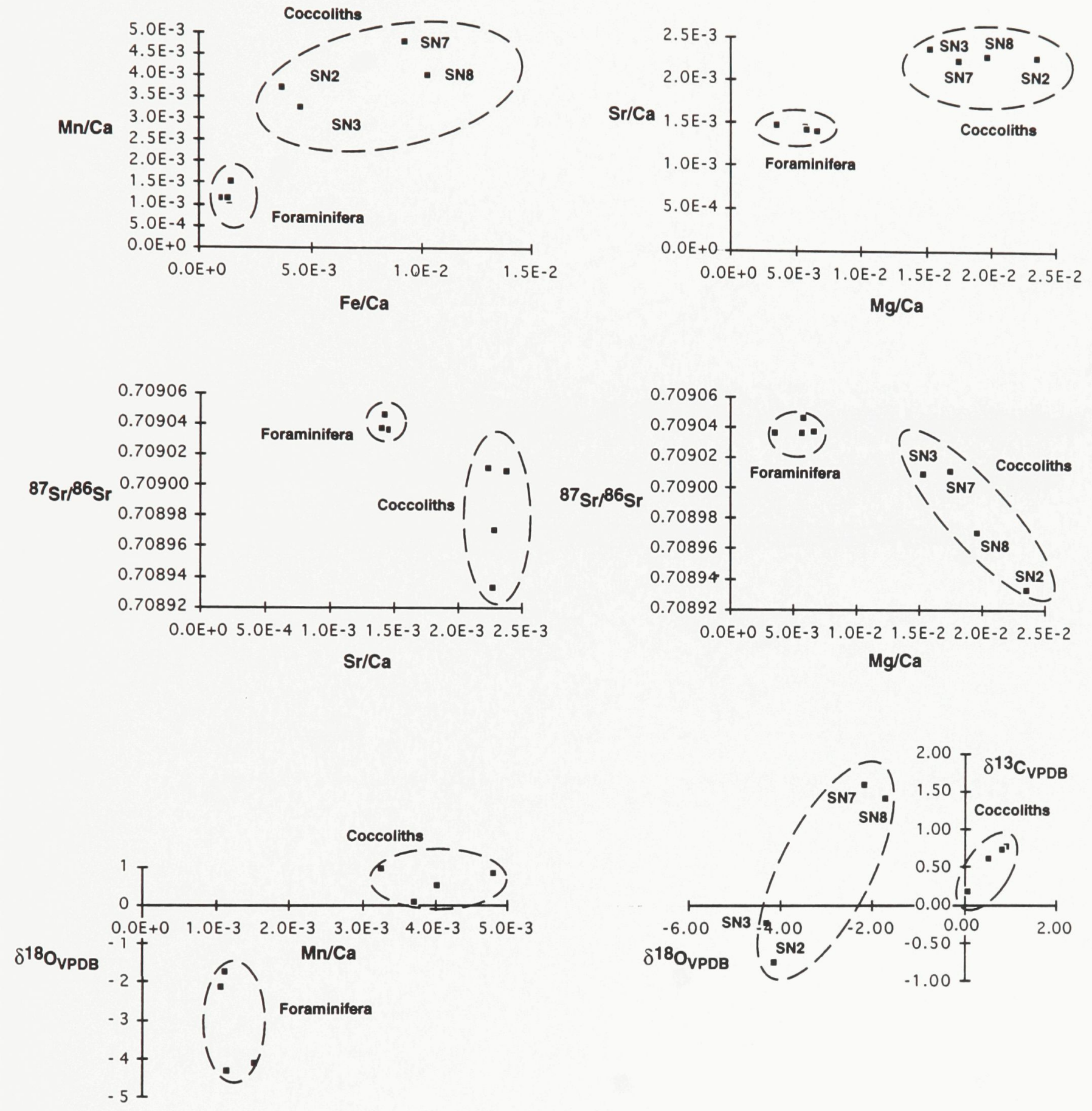
Fig. 2-7. Bivariate plots of the trace element and ${ }^{87} \mathrm{Sr} / 86 \mathrm{Sr}$ values of the porewaters from the Monte Singa section, the Eraclea Minoa section and modern seawater. Note the clear separation of the Eraclea Minoa values and those from the Monte Singa section. 

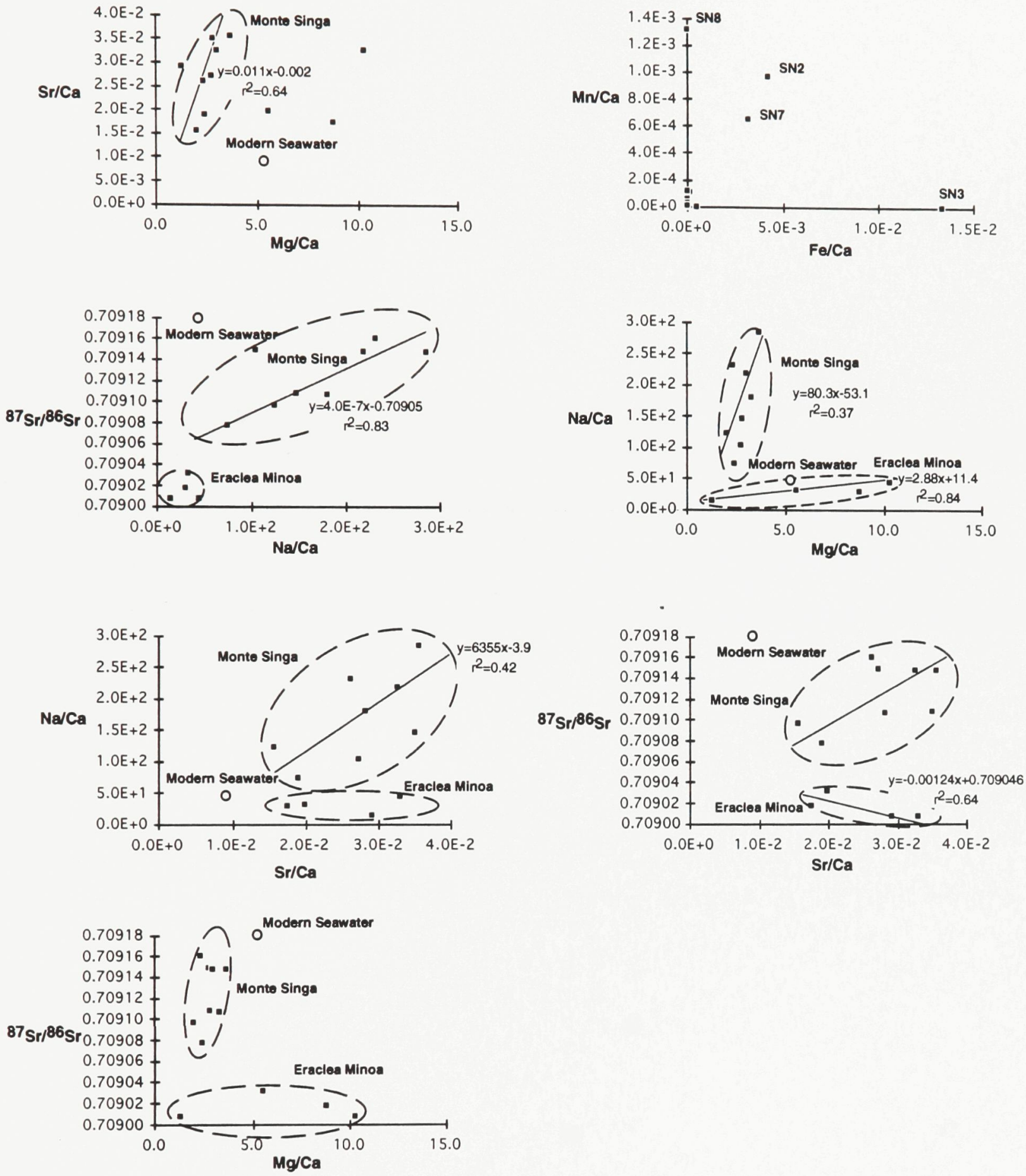
Fig. 2-8. Two-component mixing equation with foraminiferal and coccolith calcite as two end-members. Dashed line is the mixing curve for limestones and the solid line is the mixing curve for the marls. Vertical dashed line represents the percent contamination of the foraminiferal calcite that is needed to obtain the $2 \times 10^{-5}$ difference in the ${ }^{87} \mathrm{Sr} /{ }^{86} \mathrm{Sr}$ ratios found in the Precariti section. 
Micropaleontological Components

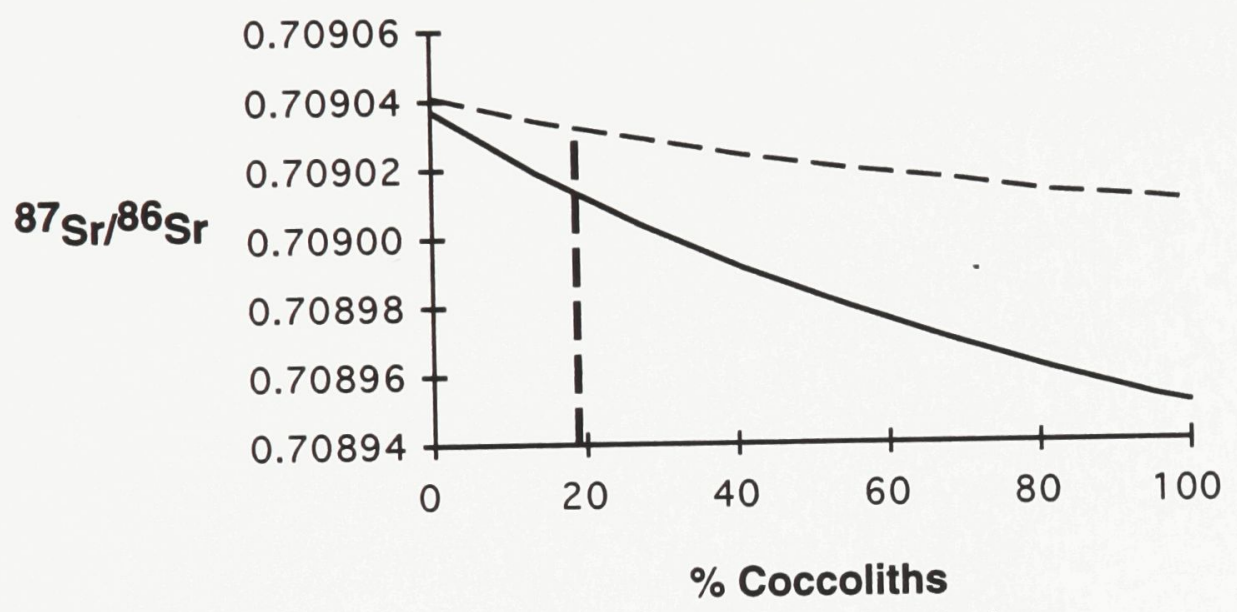

(in carbonate fraction) 
Table 2-1. Strontium isotope data for the Precariti section (PR samples) and the Monte Singa section (SN samples). The uncertainty $(2 \sigma)$ is included as a measure of the quality of the determination. 


\begin{tabular}{|c|c|c|c|c|}
\hline Sample & $\begin{array}{c}\text { Hydrochloric } \\
\text { Acid } \\
\text { 87Sr/86Sr }\end{array}$ & $2 \sigma$ & $\begin{array}{l}\text { Acetic } \\
\text { Acid } \\
\text { 87Sr/86Sr }\end{array}$ & $2 \sigma$ \\
\hline PR1 & 0.709054 & 13 & - & - \\
\hline PR2 & 0.709028 & 22 & - & - \\
\hline PR3 & 0.709035 & 28 & - & - \\
\hline PR4 & 0.709029 & 24 & - & - \\
\hline PR5 & 0.709020 & 28 & 0.709038 & 9 \\
\hline PR6 & 0.709047 & 24 & 0.709058 & 12 \\
\hline PR7 & 0.709017 & 22 & 0.709057 & 8 \\
\hline PR8 & 0.709044 & 15 & 0.709047 & 9 \\
\hline PR9 & 0.709018 & 11 & 0.709029 & 7 \\
\hline PR10 & 0.709046 & 14 & 0.709057 & 10 \\
\hline PR11 & 0.709026 & 13 & - & - \\
\hline PR12 & 0.709049 & 12 & - & - \\
\hline PR13 & 0.709014 & 21 & - & - \\
\hline PR14 & 0.709046 & 2 & - & - \\
\hline PR15 & 0.709030 & 13 & - & - \\
\hline PR16 & 0.709034 & 11 & - & - \\
\hline PR17 & 0.709025 & 16 & - & - \\
\hline Mean & 0.709033 & 26 & 0.709048 & 24 \\
\hline SN1 & - & - & 0.709033 & 9 \\
\hline SN2 & - & - & 0.709033 & 8 \\
\hline SN3 & - & - & 0.709044 & 12 \\
\hline SN4 & - & - & 0.709068 & 8 \\
\hline SN5 & - & - & 0.709053 & 8 \\
\hline SN6 & - & - & 0.709043 & 9 \\
\hline SN7 & - & - & 0.709057 & 11 \\
\hline SN8 & - & - & 0.709063 & 10 \\
\hline SN9 & - & - & 0.709060 & 10 \\
\hline SN10 & - & - & 0.709055 & 10 \\
\hline SN11 & - & - & 0.709071 & 8 \\
\hline SN12 & - & - & 0.709072 & 11 \\
\hline SN13 & - & - & 0.709056 & 8 \\
\hline SN14 & - & - & 0.709061 & 13 \\
\hline SN15 & - & - & 0.709045 & 12 \\
\hline SN16 & - & - & 0.709048 & 8 \\
\hline SN17 & - & - & 0.709046 & 8 \\
\hline SN18 & - & - & 0.709046 & 10 \\
\hline SN19 & - & - & 0.709045 & 8 \\
\hline SN20 & - & - & 0.709047 & 7 \\
\hline SN21 & - & - & 0.709053 & 8 \\
\hline SN22 & - & - & 0.709035 & 9 \\
\hline SN23 & - & - & 0.709064 & 10 \\
\hline SN24 & - & - & 0.709057 & 9 \\
\hline Mean & & & 0.709052 & 22 \\
\hline
\end{tabular}


Table 2-2. Strontium isotope data $\left({ }^{87} \mathrm{Sr} / 86 \mathrm{Sr}\right)$ of the constituents of the four limestone and marl samples from the Monte Singa section. The uncertainty $(2 \sigma)$ is included as a measure of the quality of the determination. 


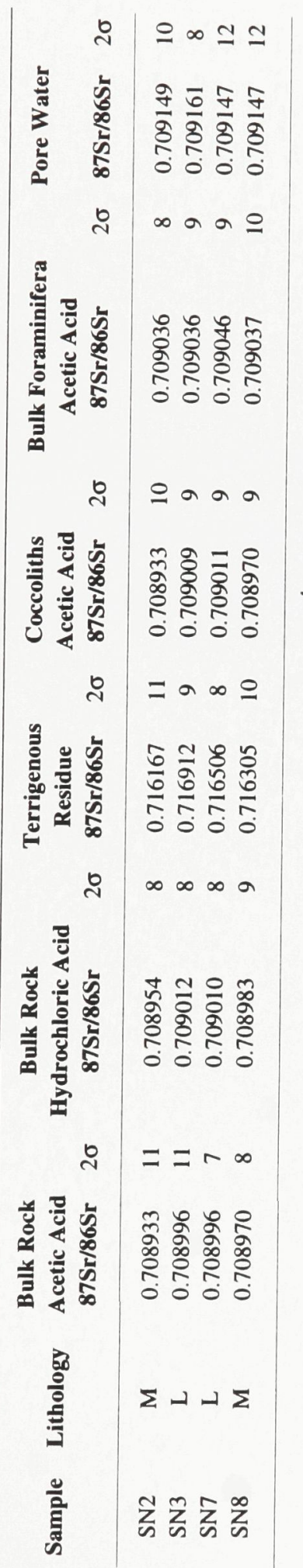


Table 2-3. Strontium isotope data $\left({ }^{87} \mathrm{Sr} / 86 \mathrm{Sr}\right)$ of the foraminifera and the porewater from the Monte Singa section (SN) and from the Eraclea Minoa section (EM). The uncertainty $(2 \sigma)$ is included as a measure of the quality of the determination. 


\begin{tabular}{ccccc}
\hline & $\begin{array}{c}\text { Foraminifera } \\
\text { 87Sr/86Sr }\end{array}$ & $2 \sigma$ & $\begin{array}{c}\text { Porewater } \\
\text { 87Sr/86Sr }\end{array}$ & $2 \sigma$ \\
\hline SN2 & 0.709036 & 8 & 0.709149 & 10 \\
SN3 & 0.709036 & 9 & 0.709161 & 8 \\
SN7 & 0.709046 & 9 & 0.709147 & 12 \\
SN8 & 0.709037 & 10 & 0.709147 & 12 \\
Mean & 0.709039 & 10 & 0.709151 & 14 \\
\hline SN18 & 0.709046 & 10 & 0.709096 & 9 \\
SN19 & 0.709045 & 8 & 0.709107 & 10 \\
SN20 & 0.709047 & 7 & 0.709078 & 10 \\
SN21 & 0.709053 & 8 & 0.709108 & 10 \\
Mean & 0.709048 & 8 & 0.709097 & 28 \\
& & & & \\
\hline EM4 & 0.709012 & 10 & 0.709007 & 11 \\
EM5 & 0.709015 & 9 & 0.709018 & 8 \\
EM16 & 0.709029 & 9 & 0.709031 & 9 \\
EM17 & 0.709024 & 8 & 0.709007 & 9 \\
Mean & 0.709020 & 16 & 0.709016 & 22 \\
\hline
\end{tabular}


Table 2-4. Trace element concentrations in ppt (mg/g) of the foraminifera, coccoliths and terrigenous fractions of the marls and the limestones. 


\begin{tabular}{|c|c|c|c|c|}
\hline \multicolumn{5}{|c|}{ Foraminifera } \\
\hline & SN2 & SN3 & SN7 & SN8 \\
\hline $\mathrm{Ca}$ & 365.5 & 375.7 & 373.8 & 352.1 \\
\hline $\mathrm{Mg}$ & 0.8 & 1.3 & 1.3 & 1.4 \\
\hline $\mathrm{Na}$ & 0.8 & 0.7 & 0.7 & 0.7 \\
\hline $\mathrm{Fe}$ & 0.717 & 0.522 & 0.699 & 0.629 \\
\hline $\mathrm{Mn}$ & 0.767 & 0.587 & 0.544 & 0.544 \\
\hline $\mathrm{Sr}$ & 1.169 & 1.193 & 1.160 & 1.079 \\
\hline \multicolumn{5}{|c|}{ Coccoliths } \\
\hline & SN2 & SN3 & SN7 & SN8 \\
\hline $\mathrm{Ca}$ & 338.6 & 398.4 & 386.4 & 380.9 \\
\hline $\mathrm{Mg}$ & 4.8 & 3.7 & 4.1 & 4.5 \\
\hline $\mathrm{Na}$ & 0.4 & 0.4 & 0.4 & 0.5 \\
\hline $\mathrm{Fe}$ & 1.752 & 2.533 & 4.972 & 5.441 \\
\hline $\mathrm{Mn}$ & 1.720 & 1.770 & 2.545 & 2.101 \\
\hline $\mathrm{Sr}$ & 1.677 & 2.066 & 1.882 & 1.904 \\
\hline \multicolumn{5}{|c|}{ Terrigenous } \\
\hline & SN2 & SN3 & SN7 & SN8 \\
\hline $\mathrm{Ca}$ & 6.0 & 5.1 & 5.3 & 7.1 \\
\hline $\mathrm{Mg}$ & 10.4 & 6.9 & 8.4 & 8.0 \\
\hline $\mathrm{Na}$ & 3.5 & 3.5 & 3.2 & 3.5 \\
\hline $\mathrm{Fe}$ & 40.310 & 42.576 & 39.314 & 36.794 \\
\hline $\mathrm{Mn}$ & 0.227 & 0.214 & 0.227 & 0.258 \\
\hline $\mathrm{Sr}$ & 0.080 & 0.059 & 0.059 & 0.058 \\
\hline
\end{tabular}


Table 2-5. Porewater trace element concentrations in $\mathrm{mg}$ of element per gram of whole rock used (ppt) from the Monte Singa section (SN) and the Eraclea Minoa section (EM). Dash symbol indicates element not detected. 


\begin{tabular}{|c|c|c|c|c|}
\hline \multicolumn{2}{|c|}{ Porewater } & SN3 & SN7 & SN8 \\
\hline $\mathrm{Ca}$ & 0.60 & 0.19 & 0.30 & 0.29 \\
\hline $\mathrm{Mg}$ & 1.00 & 0.26 & 0.67 & 0.52 \\
\hline $\mathrm{Na}$ & 36.00 & 24.49 & 49.00 & 36.29 \\
\hline $\mathrm{Fe}$ & 0.0035 & 0.0034 & 0.0013 & 0.0000 \\
\hline $\mathrm{Mn}$ & 0.0008 & - & 0.0003 & 0.0005 \\
\hline \multirow[t]{2}{*}{$\mathrm{Sr}$} & 0.0358 & 0.0106 & 0.0233 & 0.0206 \\
\hline & SN18 & SN19 & SN20 & SN21 \\
\hline $\mathrm{Ca}$ & 0.47 & 0.77 & 0.47 & 0.77 \\
\hline $\mathrm{Mg}$ & 0.56 & 1.54 & 0.68 & 1.30 \\
\hline $\mathrm{Na}$ & 32.90 & 79.46 & 19.68 & 64.67 \\
\hline $\mathrm{Fe}$ & - & - & 0.0003 & - \\
\hline $\mathrm{Mn}$ & - & - & - & - \\
\hline \multirow[t]{2}{*}{$\mathrm{Sr}$} & 0.0158 & 0.0476 & 0.0192 & 0.0587 \\
\hline & EM4 & EM5 & EM16 & EM17 \\
\hline $\mathrm{Ca}$ & 3.48 & 4.62 & 3.87 & 2.14 \\
\hline $\mathrm{Mg}$ & 21.75 & 24.52 & 12.95 & 1.66 \\
\hline $\mathrm{Na}$ & 88.50 & 79.76 & 71.18 & 16.88 \\
\hline $\mathrm{Fe}$ & - & 0.0006 & - & - \\
\hline $\mathrm{Mn}$ & 0.0003 & 0.0007 & 0.0002 & 0.0003 \\
\hline $\mathrm{Sr}$ & 0.2505 & 0.1769 & 0.1677 & 0.1356 \\
\hline
\end{tabular}


Table 2-6. Ratios of trace elements relative to Ca within the four components of the limestone and marl samples in the Monte Singa (SN) and Eraclea Minoa (EM) sections.

Dash symbol indicates that the element was not detected. $\delta^{18} \mathrm{O} \%$ and $\delta^{13} \mathrm{C} \%$ values are relative to $\mathrm{PDB}$. 


\begin{tabular}{|c|c|c|c|c|c|c|c|c|}
\hline & Samples & $\mathrm{Mg} / \mathrm{Ca}$ & $\mathrm{Sr} / \mathrm{Ca}$ & $\mathrm{Fe} / \mathrm{Ca}$ & $\mathrm{Na} / \mathrm{Ca}$ & $\mathrm{Mn} / \mathrm{Ca}$ & $180 \%$ & $13 \mathrm{C} \%$ \\
\hline \multirow[t]{4}{*}{ Foraminifera } & SN2 & $3.5 \mathrm{E}-3$ & $1.5 \mathrm{E}-3$ & $1.4 \mathrm{E}-3$ & $3.7 \mathrm{E}-3$ & $1.5 \mathrm{E}-3$ & -4.12 & -0.75 \\
\hline & SN3 & $5.7 \mathrm{E}-3$ & $1.5 \mathrm{E}-3$ & $1.0 \mathrm{E}-3$ & $3.0 \mathrm{E}-3$ & $1.1 \mathrm{E}-3$ & -4.30 & -0.24 \\
\hline & SN7 & $5.8 \mathrm{E}-3$ & $1.4 \mathrm{E}-3$ & $1.3 \mathrm{E}-3$ & $3.1 \mathrm{E}-3$ & $1.1 \mathrm{E}-3$ & -2.16 & 1.58 \\
\hline & SN8 & $6.7 \mathrm{E}-3$ & $1.4 \mathrm{E}-3$ & $1.3 \mathrm{E}-3$ & $3.5 \mathrm{E}-3$ & $1.1 \mathrm{E}-3$ & -1.73 & 1.39 \\
\hline \multirow[t]{4}{*}{ Coccoliths } & SN2 & 2.3E-2 & 2.3E-3 & $3.7 \mathrm{E}-3$ & $2.2 \mathrm{E}-3$ & $3.7 \mathrm{E}-3$ & 0.07 & 0.17 \\
\hline & SN3 & $1.5 \mathrm{E}-2$ & $2.4 \mathrm{E}-3$ & $4.6 \mathrm{E}-3$ & $1.6 \mathrm{E}-3$ & $3.2 \mathrm{E}-3$ & 0.94 & 0.77 \\
\hline & SN7 & $1.7 \mathrm{E}-2$ & $2.2 \mathrm{E}-3$ & $9.2 \mathrm{E}-3$ & $1.7 \mathrm{E}-3$ & $4.8 \mathrm{E}-3$ & 0.84 & 0.73 \\
\hline & SN8 & $2.0 \mathrm{E}-2$ & 2.3E-3 & $1.0 \mathrm{E}-2$ & $2.1 \mathrm{E}-3$ & $4.0 \mathrm{E}-3$ & 0.52 & 0.6 \\
\hline \multirow[t]{4}{*}{ Terrigenous } & SN2 & 2.8 & $6.0 \mathrm{E}-3$ & 4.8 & 1.0 & 2.7E-2 & & \\
\hline & SN3 & 2.2 & $5.3 \mathrm{E}-3$ & 6.0 & 1.2 & $3.1 \mathrm{E}-2$ & & \\
\hline & SN7 & 2.6 & $5.1 \mathrm{E}-3$ & 5.3 & 1.1 & $3.1 \mathrm{E}-2$ & & \\
\hline & SN8 & 1.9 & $3.7 \mathrm{E}-3$ & 3.7 & $8.6 \mathrm{E}-1$ & $2.7 \mathrm{E}-2$ & & \\
\hline \multirow[t]{12}{*}{ Porewater } & SN2 & 2.7 & $2.7 \mathrm{E}-2$ & $4.2 \mathrm{E}-3$ & $1.0 \mathrm{E}+2$ & $9.7 \mathrm{E}-4$ & & \\
\hline & SN3 & 2.4 & $2.6 \mathrm{E}-2$ & $1.3 \mathrm{E}-2$ & $2.3 \mathrm{E}+2$ & - & & \\
\hline & SN7 & 3.7 & $3.6 \mathrm{E}-2$ & $3.2 \mathrm{E}-3$ & $2.8 \mathrm{E}+2$ & $6.5 \mathrm{E}-4$ & & \\
\hline & SN8 & 3.0 & $3.2 \mathrm{E}-2$ & - & $2.2 \mathrm{E}+2$ & $1.3 \mathrm{E}-3$ & & \\
\hline & SN18 & 2.0 & $1.6 \mathrm{E}-2$ & - & $1.2 \mathrm{E}+2$ & - & & \\
\hline & SN19 & 3.3 & $2.8 \mathrm{E}-2$ & - & $1.8 \mathrm{E}+2$ & - & & \\
\hline & SN20 & 2.4 & $1.9 \mathrm{E}-2$ & $4.8 \mathrm{E}-4$ & $7.4 \mathrm{E}+1$ & - & & \\
\hline & SN21 & 2.8 & $3.5 \mathrm{E}-2$ & - & $1.5 \mathrm{E}+2$ & - & & \\
\hline & EM4 & 10.3 & $3.3 \mathrm{E}-2$ & - & $4.4 \mathrm{E}+1$ & $5.7 \mathrm{E}-5$ & & \\
\hline & EM5 & 8.7 & $1.7 \mathrm{E}-2$ & $9.6 \mathrm{E}-5$ & $3.0 \mathrm{E}+1$ & $1.1 \mathrm{E}-4$ & & \\
\hline & EM16 & 5.5 & $2.0 \mathrm{E}-2$ & - & $3.2 \mathrm{E}+1$ & $3.1 \mathrm{E}-5$ & & \\
\hline & EM17 & 1.3 & $2.9 \mathrm{E}-2$ & - & 13.8 & $1.2 \mathrm{E}-4$ & & \\
\hline Modern & Seawater & 5.2 & $9.1 \mathrm{E}-3$ & $1.4 \mathrm{E}-5$ & $4.6 \mathrm{E}+1$ & $5.8 \mathrm{E}-6$ & & \\
\hline
\end{tabular}


Table 2-7. Table showing the compositional characters of the marl and limestone samples $(\mathrm{SN} 2,3,7,8)$ and the concentration of strontium of the four fractions relative to the bulk rock. 
$\begin{array}{llll}\text { SN2 } & \text { SN3 } & \text { SN7 } & \text { SN8 }\end{array}$

\begin{tabular}{lcccc}
\hline $\begin{array}{l}\text { \% Rock Composition } \\
\text { Foraminifera (\%) }\end{array}$ & 2 & 7 & 8 & 4 \\
Coccoliths (\%) & 43 & 54 & 54 & 50 \\
Terrigenous (\%) & 55 & 39 & 38 & 46 \\
\hline $\begin{array}{l}\% \text { Carbonate Composition } \\
\text { Coccoliths(\%) }\end{array}$ & 95 & 87 & 85 & 92 \\
Foraminifera (\%) & 5 & 13 & 15 & 8 \\
\hline $\begin{array}{l}\text { Rock Sr Concentration } \\
\text { Foraminifera Sr (ppt) }\end{array}$ & 0.02 & 0.08 & 0.09 & 0.04 \\
$\begin{array}{l}\text { Coccoliths Sr (ppt) } \\
\text { Terrigenous Sr (ppt) }\end{array}$ & 0.72 & 1.12 & 1.02 & 0.95 \\
Porewater Sr (ppt) & 0.04 & 0.02 & 0.02 & 0.03 \\
\hline
\end{tabular}


Plate 2-1. 1. Altered coccoliths from Pliocene Trubi Formation of southern Italy. Cocolith plate with arrow showing thickening from overgrowth (mag.10,625x). 2. Partially overgrown coccolith plate (mag.10,625x). 3. Completely overgrown coccolith plate (mag.13,750x). 4. Coccolith plate with arrow pointing to overgrowths in central portion (mag.10,120x). 5. Extensively corroded and overgrown discoaster (mag.10,135x). 6. Side view of coccolith platelet showing increased thickness with overgrowth (mag.11,250x). 


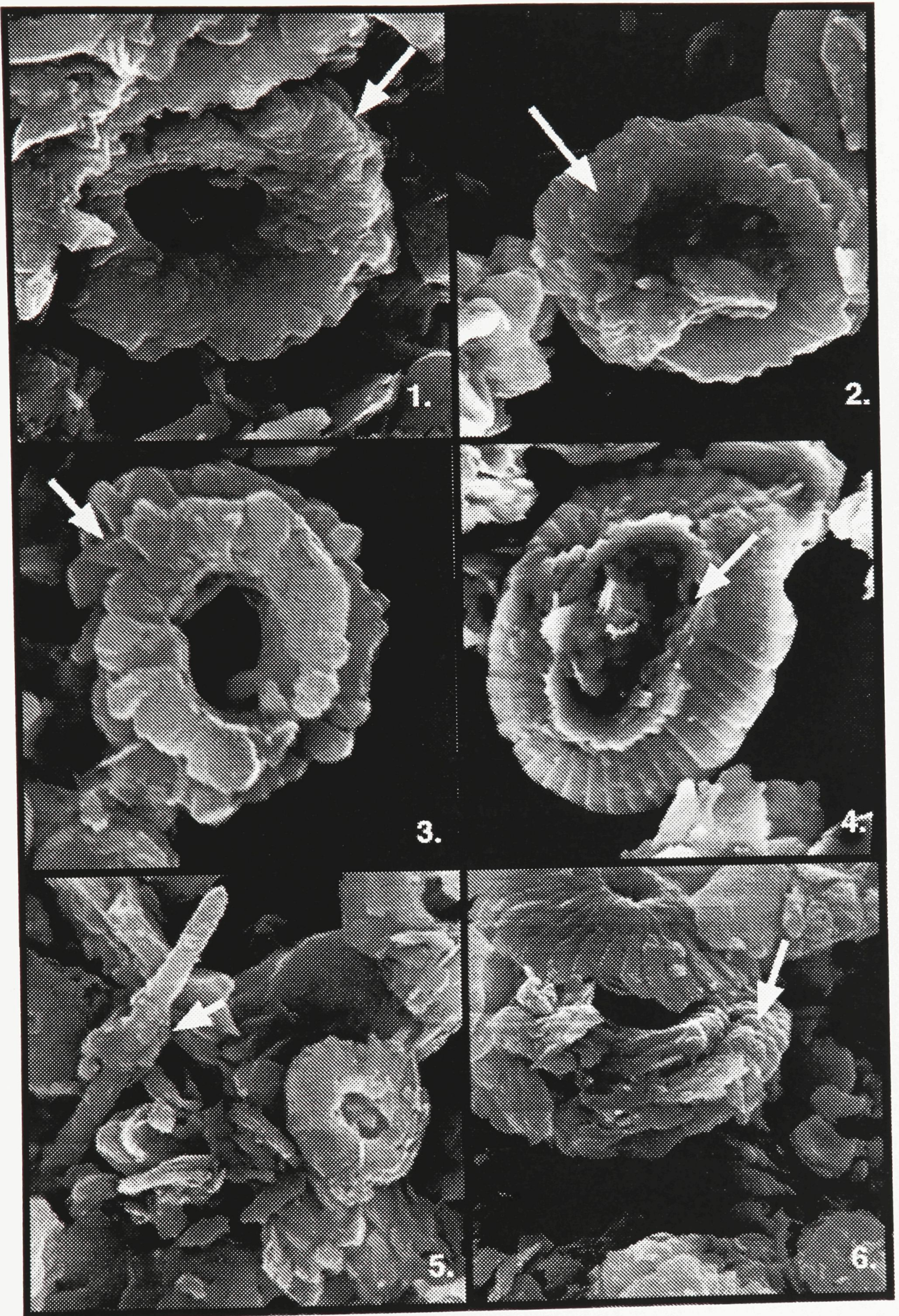


Plate 2-2. Coccoliths and foraminifera from the Pliocene Trubi Formation of southern Italy. 1. Discoaster showing results of overgrowth (mag.12,500x). 2. Coccolith platelet showing corroded margin (arrow) and overgrowth features (mag.13,330x). 3. Cross section through the tests of two planktic foraminifera showing preservation of microstructure (SEM in backscatter mode; mag.200x). 4. The same image in normal mode showing (arrows) the partial infilling of the test with sediment (mag.200x). 


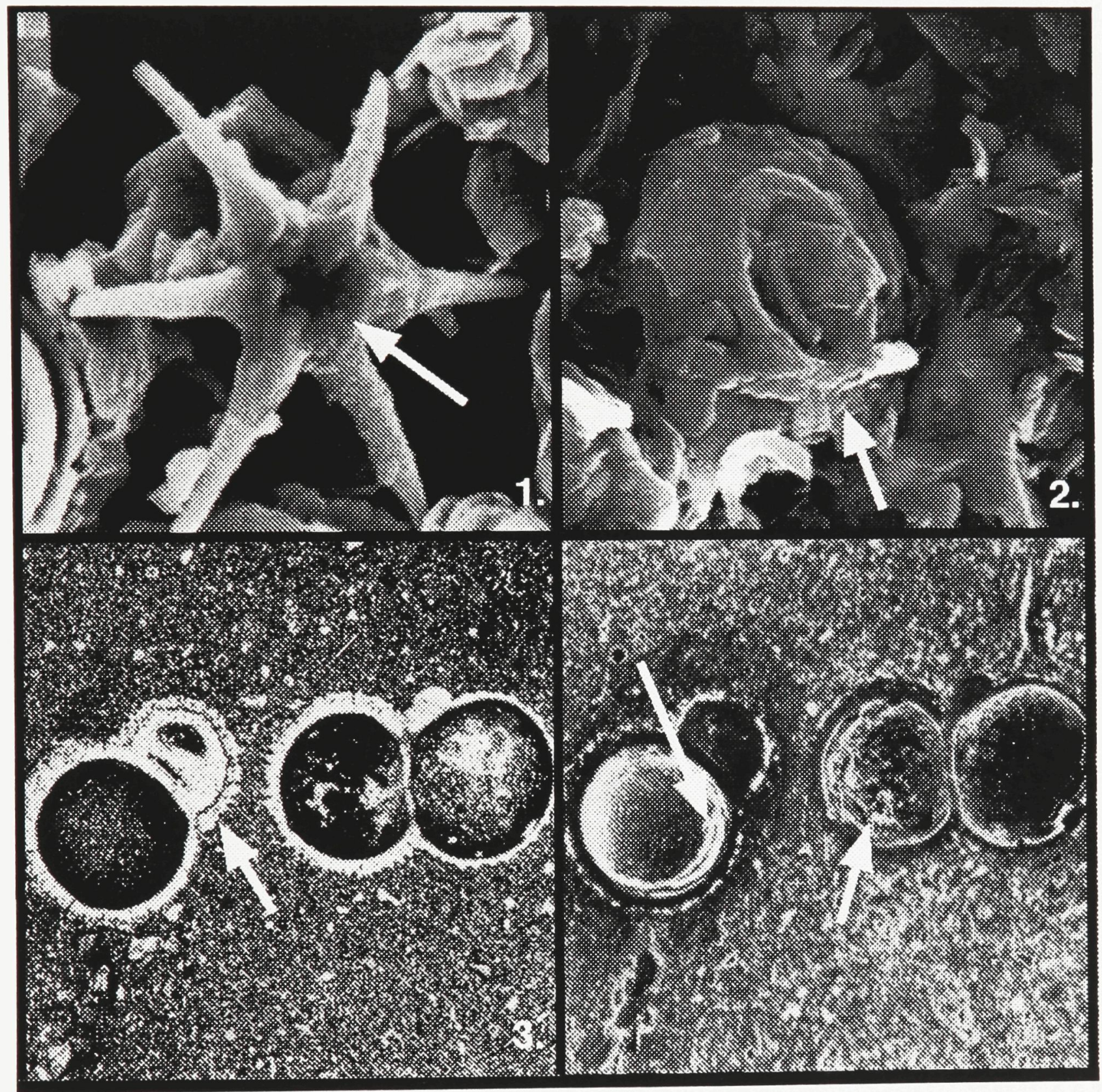


Appendix 2-1. Strontium isotope analytical methods for the samples from the Precariti section and the Monte Singa section. 


\section{Precariti Section}

The samples were oven dried and then soaked in kerosene which was decanted after several hours, water and soda ash were then added and the mixture was heated and allowed to boil (a subsequent procedure determined that the samples were so poorly indurated that soaking in freshwater overnight caused complete disaggregation of the samples). Once disaggregated, the sample was sieved through a 63 micron mesh screen removing the silt and clay sized fraction. The samples were then dried under heat lamps. Afterward, the foraminifera were separated from the mineral fraction using a heavy liquid $\left(\mathrm{CCl}_{4}\right.$, s.g. 1.56). Individual foraminiferal tests were hand picked using a vacuum picker (sample size was 3 to $5 \mathrm{mg}$ ), washed in pure water (ultrasound), and then dissolved in $2.5 \mathrm{~N} \mathrm{HCl}$. Sr and $\mathrm{Ca}$ were separated from the sample solutions using ion-exchange columns of Bio-Rad AG50 X-8 resin with $2.5 \mathrm{~N} \mathrm{HCl}$ as the eluting agent. The separation of $\mathrm{Sr}$ from $\mathrm{Ca}$ was achieved using a second column that used Teflon powder coated with bis(2-ethylhexyl) phosphoric acid (HDEHP), with $0.01 \mathrm{~N} \mathrm{HCl}$ as the eluting agent (Patterson et al., 1995). The isotopic composition of the Sr was measured on a Finnigan-MAT 261 multicollector mass spectrometer operated in static mode. Replicate analysis of NBS 987 standard over the analysis period had a mean ${ }^{87} \mathrm{Sr} / 86 \mathrm{Sr}$ ratio of $0.710248 \pm 20(2 \sigma)$ and our laboratory blank was $<400$ picograms.

\section{Monte Singa Section}

In contrast to the methodology used for the Precariti section, the Monte Singa samples were crushed and washed in a dilute $\mathrm{HCl}$ solution $(0.01 \mathrm{~N})$ to dissolve any carbonate contaminants and to etch the outer surface of the foraminiferal tests. This was followed by a ultrasound wash in high purity water. Samples were then dissolved in concentrated acetic acid (80\%) to minimize the dissolution of any siliciclastic contaminants and the solution was drawn off before all the carbonate was consumed. The sample 
solutions were then centrifuged to remove any residue and then dried down and reacidified with $2.5 \mathrm{~N} \mathrm{HCl}$. Subsequent chemical procedures followed those of the Precariti section. 
Appendix 2-2. Separation and geochemical analytical procedures for the four components of the marl and limestone lithologies. 


\section{Separatory and Geochemical Methods}

\section{Silt and Clay-Sized Terrigenous Sediment}

The silt and clay-sized terrigenous sediment was isolated from the suite of four samples (two marls and two limestones) by dissolving the carbonate fraction with acetic acid. Samples were disaggregated by soaking each sample in pure water for twenty-four hours. The samples immediately began to disaggregate and did not require the more rigorous cleaning procedure described previously. The silt/clay fraction was collected by sieving through a 53 micron sieve and the terrigenous component was isolated by dissolving the carbonate in a concentrated weak acid (acetic 80\%) to minimize the dissolution of clays. The residue was retained and then repeatedly rinsed in pure water to remove any trace of dissolved carbonate. The terrigenous residue was dissolved using the following combination of acids: 1) $15 \mathrm{ml}$ of weak nitric (2-3N) acid was added to approximately $200 \mathrm{mg}$ of sample which was then gently warmed $\left(100^{\circ} \mathrm{C}\right)$ and dried down to a moist paste; 2$)$ a solution of concentrated $\mathrm{HF}(6 \mathrm{ml})$ and strong nitric $(12 \mathrm{~N} ; 1 \mathrm{ml})$ acid was then added and the samples were capped and left for twenty four hours to flux at 125 ${ }^{\circ} \mathrm{C}$ and then allowed to dry down to a moist paste; 3 ) nitric acid (9N) was then added, allowed to evaporate, and reacidified with $2 \mathrm{ml}$ of $6.0 \mathrm{~N} \mathrm{HCl}$. The samples were capped and gently heated at $125^{\circ} \mathrm{C}$ for $\left.24 \mathrm{hrs} ; 5\right)$ the sample solutions were then dried down and reacidified with $1.5 \mathrm{ml}$ of $\mathrm{HCl}(2.5 \mathrm{~N})$, capped, and gently heated for twenty-four hours.

Strontium isotopic analysis followed the same procedure as described above.

Geochemical analysis for $\mathrm{Sr}, \mathrm{Ca}, \mathrm{Fe}, \mathrm{Na}, \mathrm{Mg}, \mathrm{Mn}$ was carried out by ICP (Inductively Coupled Plasma) analysis from ARECO (Nepean, Ontario, Canada). Aliquots of solution were dried down and reacidified (2.5 $\left.\mathrm{N} \mathrm{HNO}_{3}\right)$ for ICP analysis.

$\mathrm{X}$-ray diffraction determined the mineralogy of the terrigenous component. The silt and clay-sized particles in both the limestone and marl samples were composed of quartz, hydrous micas, chlorite, kaolinite and feldspars. Previous research on the Trubi fm. from 
Sicily determined the clay mineralogy in more detail and revealed the presence of smectite, kaolinite, illite, chlorite and palygorskite (De Visser et al., 1989)

\section{$\underline{\text { Carbonate Silt and Clay Sized Fraction (Coccoliths) }}$}

The coccolith component (3-15 microns) of the silt and clay sized sediment was concentrated by repeated gravity settling to remove the coarser and finer fractions. The concentration of coccoliths was then determined using both light microscopy and an SEM. The coccoliths were washed several times in pure water and then selectively dissolved using concentrated acetic acid (80\%) to minimize any potential contaminating effect of the clay minerals. Aliquots of solution were analysed both geochemically and isotopically ( $\mathrm{Sr}$ ) as described above. In addition, oxygen and carbon isotopic compositions were determined at the Ottawa-Carleton Geoscience Centre Stable Isotope Facility at the University of Ottawa. Samples were baked in a deuterium furnace at $400{ }^{\circ} \mathrm{C}$ under vacuum to remove any organic compounds within the sediment. Samples were then dissolved with $\mathrm{H}_{3} \mathrm{PO}_{4}$ and analyzed with a VG (SIRA-12) mass spectometer using standard carbon and oxygen isotope analytical techniques.

\section{Foraminifera}

The foraminiferal tests were similarily analyzed for elemental and isotopic composition. The strontium isotopic analysis used a bulk sample of foraminiferal tests that were cleaned in $\mathrm{HCl}$ and then dissolved in acetic acid (80\%). The oxygen and carbon isotopic determinations were carried out following the same procedure used for the coccoliths on 3-6 clean hand picked tests of Globigerinoides obliquus. In addition, the elemental analyses ( $\mathrm{Sr}, \mathrm{Na}, \mathrm{Ca}, \mathrm{Mn}, \mathrm{Mg}, \mathrm{Fe}$ ) of the bulk foraminiferal samples were also conducted in a fashion similar (ICP-AES) to that done for the coccolith fractions. Before elemental analysis, the tests were cleaned in a weak solution of $\mathrm{HCl}(0.01 \mathrm{~N})$, followed by a wash in pure water in an ultrasonic bath. 


\section{Pore Water Geochemistry}

Whole rock samples from the Monte Singa section were soaked in pure water until they were completely disaggregated (48hrs) to remove any dissolvable salts. In contrast, the Eraclea Minoa samples were generally more indurated and did not completely disaggregate after two days of soaking in water. Aliquots of the disaggregating solution were drawn off for geochemical and strontium isotopic analysis. The solutions were allowed to sit undisturbed for four days and then repeatedly centrifuged to remove any particulate matter. Solutions were then dried down and acidified with $2.5 \mathrm{~N} \mathrm{HCl}$ for strontium isotope analysis and $2.5 \mathrm{~N} \mathrm{HNO}_{3}$ for ICP analysis. The elemental results are reported as concentrations per gram of total oven dried rock, and as ratios relative to calcium so that they may be related to the other fractions within the rocks as the porosity of the individual samples was not known. 


\section{CHAPTER 3. A Combined Micropaleontological/Strontium Isotopic Methodology as a Paleosalinity Indicator; Evidence from King Herod the Great's Harbor, Caesarea Maritima, Israel}

\section{ABSTRACT}

Archaeological excavations within the inner harbor at Caesarea Maritima, Israel have been conducted to understand the history of the ancient harbor built by Herod the Great at the end of the 1st c. BC. An integrated foraminiferal and strontium isotope analysis $\left({ }^{87} \mathrm{Sr} / 86 \mathrm{Sr}\right)$ of three stratigraphic sections (Areas, $\left.19, \mathrm{I} 14, \mathrm{TN} 1\right)$ from the inner harbor has greatly enhanced the archaeological interpretation. The foraminiferal analysis of forty-two sediment samples and forty-two ${ }^{87} \mathrm{Sr} /{ }^{86} \mathrm{Sr}$ measurements of six fossil taxa have indicated temporal paleosalinity changes that can be related to the form and function of the inner harbor. The recognition of three salinity controlled biofacies was based on the diversity and distribution of hyaline, agglutinated, and porcelaneous foraminiferal taxa.

Areas I9 and I14 in the inner harbor were situated in a restricted but relatively well circulated brackish water environment in at least the $1 \mathrm{st} \mathrm{c} . \mathrm{AD}$ and probably up to the $3 \mathrm{rd} \mathrm{c}$. $\mathrm{AD}$ with periods of higher salinity. A highly restricted lagoon dominated by the deposition of organic matter was created, probably by formation of a sand bar, sometime during the 3rd c. AD. The lagoon became more restricted and brackish and began to shoal and be breached on a regular basis by marine waters by the 5 th $\mathrm{c}$. AD. Continued infilling of the brackish water lagoon with sand overwash deposits continued into at least the 7th $\mathrm{c}$. AD.

Area TN1, which was further seaward in the inner harbor was a quiet restricted brackish water environment in the 6th -7 th $\mathrm{c}$. $\mathrm{AD}$ and may have been the center of harbor activity during this time. The restriction of this area was likely due to a renovation in the form of a seawall or a sandbar. The area was deliberately infilled with rubble, probably in the 7th c. $\mathrm{AD}$, to prevent seaborn naval invasions. 
This paleoenvironmental study using an integrated micropaleontological/strontium isotope approach emphasizes the potential of the methodology for the study of salinity changes in coastal lagoon environments. 


\section{INTRODUCTION}

Ongoing archaeological studies at Caesarea Maritima, Israel are being carried out to determine the history of the ancient harbor built by Herod the Great in 1st c. BC. As part of this work, we previously carried out a combined micropaleontological and archaeological study to provide detailed information on the timing and nature of events which determined the history and condition of the outer harbor at Caesarea (Reinhardt et al., 1994). To our knowledge, this was the first time foraminiferal studies had ever been used in archaeological investigations of ancient harbors.

The main goal of the present study is to document further the areal and temporal environmental changes within the ancient inner harbor in order to enhance archaeological interpretation and to shed light on its environmental history. We also wanted to test the use of a combined micropaleontological and strontium isotope methodology as a high resolution paleosalinity proxy in marginal marine environments. This study from the ancient harbor at Caesarea demonstrates the use of this combined methodology, not only for marine archaeological research, but also for paleoenvironmental investigations in the earth sciences.

\section{Historical Context}

Caesarea is a historical site situated on the Israeli Mediterranean coast $\left(34^{\circ} 53.5^{\prime} \mathrm{E}\right.$ $32^{\circ} 30.5^{\prime} \mathrm{N}$ ) midway between modern Tel Aviv and Haifa (Fig. 3-1). In 21 BC, King Herod the Great, ruler of the Jewish state of Judea, commissioned an all-weather harbor at Caesarea (Holum et al., 1988; Raban, 1992). He hoped to ingratiate himself with the new ruler of Rome, Caesar Augustus, and at the same time to satisfy some of his economic needs. The harbor was built at an existing Hellenistic site called Straton's Tower, that comprised a small settlement and harbor (Raban, 1989; Raban, 1992). The construction of the harbor was difficult due to the natural constraints presented by the Israeli coastline since the coast is straight with no natural topography that could be expanded upon to build a 
harbor (Raban and Hohlfelder, 1981; Fig. 3-1). However, Herod's engineers succeeded in overcoming this limitation by using hydraulic concrete, a new Roman building material, to form the breakwaters of an all-weather harbor (Raban, 1989; Raban, 1994; Brandon, 1996; Fig. 3-2). Construction of the harbor took twelve years, and Herod named the completed city Caesarea and the harbor Sebastos (Greek for Augustus; Raban, 1989).

Current research suggests that the ancient harbor started to degenerate as early as the first century $\mathrm{AD}$, affecting its ability to provide safe haven for ships (Raban, 1989; 1995). Underwater excavations on the tip of the southern breakwater (Fig. 3-1) revealed a shipwreck that was carrying lead ingots from the period of the Emperor Domitian (83-96 AD) (Raban, 1995; Raban et al., 1997a; Fig. 3-1). Primary documents also suggest that by $500 \mathrm{AD}$, four hundred years later, the harbor was in very poor condition (Hohlfelder, 1985; Hohlfelder, 1988; Raban, 1992; Raban 1994). Procopius of Gaza, an early Christian bishop, wrote and complained to the Roman Emperor Anastasius I (491-518 AD) that he used to watch ships wreck regularly in the exposed harbor (Raban, 1989). Not long after Procopius' account, it appears that Anastasius provided means by which the harbor could be refurbished, although the extent of this refurbishment is not known (Oleson et al., 1984; Raban, 1989; Raban, 1991; Raban 1992; Raban, 1994). While the precise historical record of the ancient harbor remains to be revealed, it is apparent that it embodied many forms during its history and was used in various configurations and capacities up to the Crusader period (1265 AD), after which it was destroyed and abandoned (Holum et al. 1988). The Herodian breakwaters are presently submerged $5 \mathrm{~m}$ below the water surface (Figs. 3-1, 3-2). There is ample archaeological and geological evidence indicating that the submergence was due to subsidence from tectonic activity which may have occurred sometime during the seventh century $\mathrm{AD}$, although the exact date is not known (Mart and Perecman, 1996; Fig. 3-1).

The ancient harbour was divided into three sections enclosed by breakwaters: an outer, middle, and inner harbour (for detailed discussion of the outer harbor see Reinhardt 
et al., 1994). To understand better the general history of the ancient harbor, researchers have begun to focus on its individual sections, and excavations within the inner harbor have been conducted in detail since 1991 (Raban, 1996). Archaeologists report that the inner harbour may reflect the artificial rock-cut harbour of the original Straton's Tower (Raban, 1989; Yule and Barham, 1997; see Raban, 1996 for summary and description of inner harbor archaeological research; Fig. 3-7). When functional, the inner harbor may have been protected from siltation by sluicing channels which were intended to flush sediments from the harbour as part of a sediment-management system (Raban, 1989; Yule and Barham, 1997). Additionally, the inner harbor environment may also have been further restricted by the presence of a tower wall (Raban, 1989). Currently, the inner harbor is silted up and landlocked. The sedimentary, micropaleontological, and archaeological record preserved in the silted inner harbor provides a unique opportunity for the reconstruction of the history of the ancient harbor that cannot be provided by the outer harbor. Not only was the inner harbor tectonically stable (it lies east of the two fault lines; $3-1)$, but it has not been subjected to the same degree of destructive physical processes as the outer harbor.

To understand the processes which may have affected the marine environment of the inner harbor, it is important also to understand the sources of freshwater which fed the ancient city of Caesarea and may have flowed into the inner harbor. Throughout its history, Caesarea had two main sources of freshwater: springs in the Carmel mountains from which freshwater was conducted to the city via a series of aqueducts (high level and low level) that spanned a distance of up to $19 \mathrm{~km}$ (Olami and Peleg, 1977; Raban, 1989), and local groundwater from excavated wells. The water from the springs in the Carmel are derived predominantly from Cretaceous limestone and dolostones (Issar, 1990; Mart and Perecman, 1996). The groundwater on the coastal plain flows primarily through Pleistocene marine calcareous sandstones (locally known as kurkar). Precipitation on the coastal plain penetrates and infiltrates the subsurface and accumulates on underlying clays 
of Neogene age, forming a regional groundwater table with flow towards the Mediterranean (Issar, 1990). Near the Mediterranean, ephemeral streams become perennial due to groundwater discharge (Issar, 1990).

\section{Foraminifera}

Foraminifera are testate unicellular animals (protozoans) that inhabit a wide variety of marine and marginal marine environments and have proven to be a very useful tool for paleoenvironmental analysis in the earth sciences and, more recently, in marine archaeology (Fedje, 1993; Reinhardt et al., 1994; Reinhardt et al., 1996). Foraminifera may be omnivores, carnivores, herbivores or detritivores and use pseudopodia (net-like extensions of protoplasm) to anchor, move and retrieve food. They live on or below the sediment surface (benthic; epifaunal or infaunal), or float in the upper water column in the deep ocean (planktic; Culver, 1993).

Foraminiferal shell types may be divided into three categories based upon their composition; organic (membranous or tectinous), agglutinated, and calcareous. The agglutinated shells are composed of foreign sediment particles glued together with an organic cement, and the calcareous shells are formed from secreted calcium carbonate. The calcareous shells can be further subdivided into hyaline, porcelaneous and microgranular types which differ in their calcite crystal arrangement (Culver, 1993)

The proportions of different shell types and the diversity of foraminiferal fauna (Fisher Index; Murray, 1991) have been shown to be useful indicators of paleo-seawater salinities (Murray, 1991). The relative proportions of porcelaneous, hyaline, and agglutinated genera follow a general pattern with the agglutinated and hyaline taxa tending to dominate brackish water environments and the porcelaneous dominating more normal marine and hypersaline conditions (Murray, 1991). Bolivinid-type genera, although part of the hyaline shell assemblage, have been shown to indicate depressed oxygen levels or hypoxia (Murray, 1991; Sen Gupta and Machain-Castillo, 1993; Tables 1-3). The 
bolivinid specimens in this depressed oxygen environment tend to be small, and thinwalled (Sen Gupta and Machain-Castillo, 1993).

Foraminifera are an ideal tool for paleoenvironmental analysis since: 1) they are very abundant in most marine and marginal marine environments, with a living population density often exceeding one million individuals per square meter; 2) they have a mineralized shell and thus have a high preservation potential in the sedimentary record; 3) only small sediment samples are needed to obtain fossil populations large enough for statistical treatment; 4) being single-celled organisms they respond rapidly to environmental changes; 5) many foraminiferal species characterize very specific environments; and 6) many species form a carbonate test that records the isotopic and trace elemental water chemistry of the environment in which they lived.

Due to these characteristics, foraminifera are widely used in the earth sciences for a variety of applications (e.g. paleoceanography, paleoclimatology, environmental impact assessment, etc.) and there is a large body of environmental information on specific foraminiferal species. This background information makes them a powerful tool for marine archaeological research, specifically for the study of ancient harbors.

\section{Strontium Isotope Research}

Strontium isotopic data $\left({ }^{87} \mathrm{Sr} /{ }^{86} \mathrm{Sr}\right)$ have received increased attention by earth science researchers in recent years as a chronostratigraphic tool for the dating of marine deposits in the Phanerozoic (DePaolo and Ingram, 1985; McArthur, 1994; Farrell et al., 1995; Patterson et al., 1995; Zhang and Scott, 1996 and many others). The methodology is based on the observation that strontium contained in marine carbonates (biotic and abiotic) records the ${ }^{87} \mathrm{Sr} / 86 \mathrm{Sr}$ ratio of the ocean at the time of crystallization and that the ${ }^{87} \mathrm{Sr} /{ }^{86} \mathrm{Sr}$ signal is homogeneous throughout the world's oceans (residence time 2-3 Ma; mixing time approx. 1.5 Ka; Broecker, 1963; Hodell et al., 1990; Paytan et al., 1993). The methodology also depends upon observed variation in strontium $\left({ }^{87} \mathrm{Sr} / 86 \mathrm{Sr}\right)$ maxima 
and minima through the Phanerozoic (Burke et al., 1982). This temporal variation of the oceanic strontium isotopic signal has been attributed to varying fluxes from hydrothermal sources at mid-ocean ridges and continental weathering via rivers (Hodell et al., 1990; Edmond, 1992; Harris, 1995; and many others).

Environments in close proximity to the fluvial sources of strontium input may have ${ }^{87} \mathrm{Sr} /{ }^{86} \mathrm{Sr}$ ratios that deviate from that of normal seawater $(0.70918)$. This deviation can be used to advantage for paleosalinity determination in marginal marine or restricted basin environments if: 1) the fluvial Sr concentration and ${ }^{87} \mathrm{Sr} / 86 \mathrm{Sr}$ ratio are known, and 2) the fluvial strontium concentration is high and/or the ${ }^{87} \mathrm{Sr} /{ }^{86} \mathrm{Sr}$ ratio sufficiently differs from that of seawater. If an estimate of these criteria is known, the analysis of the ${ }^{87} \mathrm{Sr} /{ }^{86} \mathrm{Sr}$ ratio in skeletal material can give a paleosalinity determination of the environment in which the organism lived by using a two component mixing equation normalized to salinity with the $\mathrm{Sr}$ isotopic ratios and concentrations of freshwater and seawater acting as two end members (Faure, 1986; Schmitz et al., 1991; Ingram and Sloan, 1992; Bryant et al., 1995).

The use of strontium isotopes as a paleosalinity proxy has several advantages over conventional methods: 1) There are none of the vital effect phenomena associated with strontium isotope methodology as compared with other paleosalinity techniques such as trace elements (i.e. $\mathrm{Sr} / \mathrm{Ca}, \mathrm{Mg} / \mathrm{Ca}$ ) and oxygen and carbon isotopes (Veizer, 1983; Dodd and Stanton, 1990; Reinhardt et al, 1996); 2) The worldwide ${ }^{87} \mathrm{Sr} / 86 \mathrm{Sr}$ ratio is a constant at any given time and if diagenetic effects can be eliminated, any deviation from this value is the result of freshwater dilution; this is not the case with other geochemical proxies; and 3) There is a simple relationship between salinity and the ${ }^{87} \mathrm{Sr} /{ }^{86} \mathrm{Sr}$ ratios if the charactistics ( $\mathrm{Sr}$ concentration and ${ }^{87} \mathrm{Sr} /{ }^{86} \mathrm{Sr}$ ratio) of the freshwater and seawater are known, or can be reliably estimated. This is not always a simple relationship with other geochemical salinity proxies. 
The ecological constraints on foraminifera are generally well known and, as discussed previously, there is a general distributional trend correlated with salinity, although the distribution of many species with regard to salinity is only poorly defined (Murray, 1991). Many species are opportunistic and are euryhaline, tolerating a wide range of salinities (e.g. Ammonia tepida) while others are relatively stenohaline, existing only in narrow salinity ranges. However, many of these species also have relatively wide salinity ranges (i.e. marine to hypersaline $>32$ ppt salinity; Murray, 1991).

In this study of the inner harbor at Caesarea we wanted to have a higher resolution measurement of the temporal salinity shifts so that we could better recognize restrictions on the inner harbor and their relation to harbor form and function. By using Sr isotopic data and the ecological constraints of the foraminiferal distribution within the three stratigraphic sections within the inner harbor we were able to determine the salinity shifts at a higher resolution than with foraminifera alone. In addition, by analyzing the ${ }^{87} \mathrm{Sr} / 86 \mathrm{Sr}$ composition of the potential sources of freshwater influx and by analyzing the various fossil taxa in the sections we were able to constrain the origin of the freshwater entering the inner harbor.

\section{METHODS}

\section{Micropaleontological Methods}

Forty-two samples were analyzed from three sections in the inner harbor. The samples from Area I14 and Area I9 were recovered during land-based excavation of two trenches within the silted inner harbor; samples from Area TN1 were recovered from a trench dug underwater (Figs. 3-3, 3-4). The samples from Area I9 were recovered from the balk of an excavation trench (excavated by the Combined Caesarea Expeditions) and the samples from Area I14 were recovered from a series of sediment cores that were retrieved by the MOLAS (Museum of London Archaeological Service) team (Williamson, 1994; Yule and Rowsome, 1994; Raban, 1996; Yule and Barham, 1997; Raban et al., 1997a,b). 
In Area TN1 the sampling area was 1.5 meters below mean sea level (Fig. 3-4). SCUBA and underwater excavation techniques were used to excavate and expose a vertical face. Samples were obtained by pressing small core barrels into the five sedimentary units which, upon removal, were placed in plastic sample bags and brought to the surface. Due to the abundant archaeological material found in the sediment and the hostile working environment (wave surge) the sampling resolution of the underwater trench at Area TN1 was limited.

Samples of approximately $80 \mathrm{cc}$ were shaken in tap water on a Burrel shaker until they were broken up and suspended. They were then washed under a 63 micron sieve to remove the silt/clay sized fraction and examined with a binocular microscope (100x). Samples were then dried and floated in a heavy liquid (Carbon tetrachloride, S.G. 1.56) in order to separate the lower density foraminiferal tests from the heavier sediment grains.

The samples were divided using a dry splitter until an aliquot containing approximately 500 specimens was obtained. After quantitative analysis, species counts were compiled and changed into fractional abundances per sample.

The uncertainty for the counting errors was calculated using the methods proposed by Patterson and Fishbein (1989). The standard error is,

$$
\mathrm{SX}_{\mathrm{i}}=\left[\mathrm{X}_{\mathrm{i}}\left(1-\mathrm{X}_{\mathrm{i}}\right) / \mathrm{N}\right]^{1 / 2}
$$

where $\mathrm{SX}_{\mathrm{i}}$ is the standard error; $\mathrm{X}_{\mathrm{i}}$ is the estimated fractional abundance for each $\mathrm{i}=1,2,3 \ldots$... I species; where I= (the total number of species in a particular sample); $\mathrm{i}$ is each species; and $\mathrm{N}$ is the total number of specimens counted in a sample.

When making $\mathrm{N}$ specimen counts the actual fractional abundance $\mathrm{f}_{\mathrm{i}}$ lies between,

$$
X_{i}-1.96 S X_{i} \leq f_{i} \leq X_{i}+1.96 S X_{i}
$$


$95 \%$ of the time regardless of the number of the species contained in the sample. The $95 \%$ confidence interval on the estimated fractional abundances is therefore $\mathrm{X}_{\mathrm{i}} \pm 1.96 \mathrm{SX} \mathrm{X}_{\mathrm{i}}$.

Thirty-six species were present in statistically significant numbers in at least one of the samples (confident $95 \%$ of the time that there was at least $1 \%$ abundance in one of the samples; Appendix 3-2; Tables 3-1, 3-2). The statistically significant foraminiferal species in each sample were subsequently grouped into relative proportions of hyaline, porcelaneous, and agglutinated shell types (Tables 1-3). In addition, the bolivinid-type genera (although part of the hyaline shell type category) were separately grouped and the Fisher-Diversity Index was calculated.

Using these characters, three foraminiferal assemblages or biofacies were documented indicating three distinct depositional environments within the sections of Area I14, Area I9, and Area TN1 (Table 3-1, 3-2, 3-3). Selected specimens were mounted on a plug and coated with a palladium/gold mixture and examined on a Jeol JSM 6400 Scanning Electron Microscope at the Scanning Analytical Microscope Facility of Carleton University, Ottawa, Canada.

\section{Geochemical Methods}

Individual specimens of the various taxa (foraminifera, gastropods, bivalve, ostracod) were hand picked from the selected samples (sample size was 3 to $5 \mathrm{mg}$ ). All the specimens selected for ${ }^{87} \mathrm{Sr} /{ }^{86} \mathrm{Sr}$ determinations were in pristine condition. Only articulated bivalves and ostracods were selected for examination and foraminifera and gastropods had to be unbroken and unabraded. Samples were examined using both light microscopy and the SEM. No overgrowths, dissolution features, or evidence of recrystallization were noted on the specimens for isotopic analysis. The selection of specimens for isotopic analysis was dictated by the abundance and diversity of the various taxa, which in certain samples were very low. 
Samples for isotopic analysis $\left({ }^{87} \mathrm{Sr} / 86 \mathrm{Sr}\right)$ were cleaned in pure water (ultrasound) and then preleached in $0.01 \mathrm{~N} \mathrm{HCl}$ (to remove any carbonate contaminants), dissolved in strong acetic acid (80\%; to minimize the contaminating effect of clay minerals), dried down and then reacidified with $2.5 \mathrm{~N} \mathrm{HCl}$. Sr and $\mathrm{Ca}$ were separated from the sample solutions using ion-exchange columns of Bio-Rad AG50 X-8 resin with $2.5 \mathrm{~N} \mathrm{HCl}$ as the eluting agent. The separation of $\mathrm{Sr}$ from $\mathrm{Ca}$ was achieved in a second column that used Teflon powder coated with bis (2-ethylhexyl) phosphoric acid (HDEHP), with $0.01 \mathrm{~N} \mathrm{HCl}$ as the eluting agent (Patterson et al., 1995). The isotopic composition of the $\mathrm{Sr}$ was measured on a Finnigan-MAT 261 multicollector mass spectrometer operated in static mode. Isotopic ratios are normalized to ${ }^{86} \mathrm{Sr} / 88 \mathrm{Sr}=0.11940$. Replicate analysis of NBS 987 standard over the analysis period had a mean ${ }^{87} \mathrm{Sr} / 86 \mathrm{Sr}$ ratio of $0.710250 \pm 2.6 \times 10^{-5}(2 \sigma)$ and our laboratory blank was $<400$ picograms.

The overall precision of the ${ }^{87} \mathrm{Sr} / 86 \mathrm{Sr}$ determinations is $2 \times 10^{-5}(2 \sigma)$ which is based on the longterm analysis of the NBS 987 standard. Statistics of individual samples as two standard deviations $(2 \sigma)$ are reported as an indication of the quality of the analysis. All sample analyses had internal statistics $(2 \sigma)$ that were generally at or below $1.2 \times 10^{-5}$, which is well below the longterm uncertainty of $2 \times 10^{-5}(2 \sigma)$, indicating that all reported values are good determinations.

Travertine samples from the aqueducts were sampled from the side walls of the water channels. The precipitation of travertine will incorporate $\mathrm{Sr}$ without isotopic fractionation, recording the ${ }^{87} \mathrm{Sr} / 86 \mathrm{Sr}$ composition of the original water. Thus travertine samples should provide a weighted average of the overall ${ }^{87} \mathrm{Sr} / 86 \mathrm{Sr}$ composition of the spring water that was fed to the city. Subsamples from the central portion of the travertine were carefully cleaned in an ultrasonic bath, followed by a leach in dilute $\mathrm{HCl}(0.01 \mathrm{~N})$. Digestion was conducted with strong acetic acid in order to minimize the contaminating effect of the dissolution of any clay minerals. Separation of Sr from the samples and mass spectrometer analysis followed the procedure outlined above. 
Groundwater samples were collected from an excavation trench within the inner harbor beside an exposure of the inner pier face. The freshwater $(<0.5 \mathrm{ppt}$ total dissolved solids) within the inner harbor sediments is well above mean sea level (approx. $0.5 \mathrm{~m}$ ). Excavations further seaward, close to the present shoreline, also revealed fresh groundwater very near the surface. There was no evidence of seawater intrusion within the inner harbor sediments.

Samples of water were also collected from the modern inner harbor at a water depth of approximately $2 \mathrm{~m}$ and from the Shuni Springs in the Carmel mountains (which was taken as a comparative sample for the aqueduct travertine).

Particulate matter within the water samples was removed by allowing the samples to remain undisturbed for several months. Aliquots of approximately $10 \mathrm{ml}$ were then collected and centrifuged for 20 minutes; however, no residue was found. The aliquots were then dried down and reacidified with $2.5 \mathrm{~N} \mathrm{HCl}$, the $\mathrm{Sr}$ was separated, and the ${ }^{87} \mathrm{Sr} /{ }^{86} \mathrm{Sr}$ measured as described above.

Concentrations of $\mathrm{Sr}$ from the water samples were measured on filtered water samples by ICP-AES (Inductively Coupled (argon) Plasma Atomic Emission Spectrometer) on a Thermo Jarrell Ash Atomscan 25 at the Ottawa-Carleton Geoscience Center Geochemistry Laboratory at the University of Ottawa. The error on the measurements is approximately $\pm 1.5 \%$.

Salinities were calculated using a two-component mixing equation normalized to salinity as described by Bryant et al. (1995) where:

$$
\begin{aligned}
{ }^{87} \mathrm{Sr} / 86 \mathrm{Sr}_{\mathrm{mix}}= & {\left[{ }^{87} \mathrm{Sr} / 86 \mathrm{Sr}_{\mathrm{sw}} \mathrm{C}_{\mathrm{sw}} \mathrm{S}+{ }^{87} \mathrm{Sr} / 86 \mathrm{Sr}_{\mathrm{fw}} \mathrm{C}_{\mathrm{fw}}(1-\mathrm{S})\right] } \\
& x\left[\left(\mathrm{C}_{\mathrm{sw}} \mathrm{S}\right)+\mathrm{C}_{\mathrm{fw}}(1-\mathrm{S})\right]^{-1}
\end{aligned}
$$

and

$$
\mathrm{S}=\left(\mathrm{S}_{\mathrm{mix}}-\mathrm{S}_{\mathrm{fw}}\right) /\left(\mathrm{S}_{\mathrm{Sw}}-\mathrm{S}_{\mathrm{fw}}\right)
$$


$\mathrm{C}$ is the concentration of $\mathrm{Sr}$ in either freshwater ( $\mathrm{fw}$ ) or seawater (sw) and $\mathrm{S}$ is the salinity factor which is the fraction of idealized normal marine and freshwater salinity (35 and $0 \mathrm{ppt}$ ) with $\mathrm{S}_{\mathrm{mix}}$ as the salinity of the mixture of fresh and marine waters and $\mathrm{S}_{\mathrm{SW}}$ is the salinity of seawater. We have also taken a conservative view with our salinity calculations by considering the widely reported longterm uncertainty of $\pm 2 \times 10^{-5}(2 \sigma)$ on all our ${ }^{87} \mathrm{Sr} /{ }^{86} \mathrm{Sr}$ values.

\section{RESULTS}

\section{Sedimentology / Foraminifera}

The foraminiferal distribution in the three sections followed a distinct pattern and can be divided into three Biofacies based on the relative distribution of hyaline, miliolid, agglutinated, and bolivinid type taxa (Table 3-1,3-2, 3-3; Fig.3-4). The three biofacies and their associated sedimentological characters are described below. Sedimentological description of the Area I14 section was obtained from Williamson (1994) and Yule and Barham (1997). The sections from Areas I9 and TN1 are also mentioned in Raban et al. (1997a,b).

\section{Biofacies 1.}

Biofacies 1, found in the lowest stratigraphic portion of the harbor sediments, was deposited under quiet brackish lagoonal conditions, punctuated by episodic influxes of normal marine water.

\section{Lithology}

At all three sites, sediments containing a Biofacies 1 foraminiferal fauna were characterized lithologically by silt/clay with a variable organic matter component (Fig. 3-4).

In Area TN1, sediments containing Biofacies 1 fauna were found in the interval from -220 to $-270 \mathrm{~cm}$ below MSL. At the base of the section there was a moderate to well- 
sorted silt/clay unit ( -260 to $-270 \mathrm{~cm}$ below MSL) that overlaid the kurkar bedrock. This silt/clay unit was in turn overlaid by a compact framework-supported unit of angular pottery with a silt/clay sized matrix.

In Area 19 the Biofacies 1 depositional environment was found in the interval between -162 to $-280 \mathrm{~cm}$ below MSL (Fig. 3-4). This interval was characterized lithologically by silt/clay with a significant organic matter and angular pottery sherd component. At the base of this interval, from -265 to $-280 \mathrm{~cm}$ below MSL, there was a unit of silt/clay and very fine sand without the organic matter component (Fig. 3-4).

In Area I14 the interval bearing Biofacies 1 is lithologically similar to Area I9, although the unit was much thinner (-209 to $-264 \mathrm{~cm}$ below MSL) and the basal sand unit (-260 to $-270 \mathrm{~cm}$ below MSL) had a much coarser grain size (Fig. 3-4).

\section{Foraminifera}

The Biofacies 1 foraminiferal fauna in Areas I9, I14, and TN1 lacked a porcelaneous fraction, but had a large hyaline and bolivinid component (Tables 1-3; Fig. 34). Agglutinated foraminifera were also present in this biofacies and the faunal diversity was very low with a Fisher Index of 5.21. The lack of a porcelaneous component, the large hyaline fraction, and the low diversity were all typical of a brackish $(<32 \mathrm{ppt})$ water lagoonal environment. The porcelaneous species typically only exist under normal (32-37 ppt) to hypersaline (>37 ppt) marine conditions and are usually associated with higher diversity faunas (Murray, 1991).

The samples in Biofacies 1 also had very high abundances of Ammonia spp. with fractional abundances in some samples as high as 0.80 (Tables 3-1, 3-2). Ammonia spp. are notably euryhaline tolerating a wide range of salinities (Poag, 1981; Murray, 1991). They have been found to dominate biofacies in the brackish middle to lower reaches of Gulf of Mexico estuaries and lagoons (Poag, 1981). 
In contrast, Biofacies 1 sediments in Area TN1 (-220 to $-270 \mathrm{~cm}$ below MSL) were dominated by elphidid-type genera (Tables 3-1,3-2). Elphidid dominated biofacies typify many of the lower reaches of Gulf of Mexico estuaries and they have also been found to dominate many temperate brackish water environments (Poag, 1981; Miller et al., 1982). This interval in Area TN1 indicated slightly higher overall salinity conditions further from the shore as compared to the more landward sections of Areas I9 and I14.

The bolivinids found in Biofacies 1 sediments were all typically very small, thinwalled, and very abundant, which indicated hypoxia-type conditions (Sen Gupta and Machain-Castillo, 1993). The low oxygen condition likely was caused by the decay of the abundant organic material within the sediment which produced hypoxia (Fig. 3-4). The periodic increase of bolivinids and overall foraminiferal diversity in the Biofacies 1 intervals indicated periods of improved salinity conditions due to the influxes of marine waters probably by storm action (Fig. 3-4).

\section{Biofacies 2}

Biofacies 2, deposited in sediments above Biofacies 1, was characteristic of a quiet lagoonal environment that had fluctuating salinities due to the regular influxes of marine waters.

\section{Lithology}

In Area TN1, Biofacies 2 sediments were present in the interval between -210 to $-220 \mathrm{~cm}$ below MSL and were composed lithologically of a moderate to well-sorted sand (Fig. 3-4).

In contrast, Biofacies 2 sediments in Area I9 (-121 to $-162 \mathrm{~cm}$ below MSL) and Area I14 (-166 to $-209 \mathrm{~cm}$ below MSL) were characterized lithologically by silt/clay and organic matter, with an increased sand content as compared to Biofacies 1 (Fig. 3-4). 
Foraminifera

In the three sections (Area TN1, Area I9, and Area I14) Biofacies 2 was characterized by the first appearance of a porcelaneous foraminiferal fauna (average fractional abundance $=0.08$ ) and had a very high diversity (mean Fisher Index $=11.25$ ). However, the proportions of both agglutinated and bolivinid foraminifera were lower in this biofacies than in Biofacies 1 (Tables 1-3; Fig. 3-4).

Fluctuating foraminiferal diversity within this biofacies, particularly in Area I14, indicated a quiet environment of low salinity and hypoxia with interspersed periods of better oxygenation and higher salinity conditions probably brought about by storm action (Fig. 3-4). Although the proportions of porcelaneous foraminifera in this biofacies were higher than Biofacies 1, and are often a good indication of elevated salinities, the generally abraded nature of their shells when compared to rest of foraminiferal fauna in this biofacies indicated that they were likely transported into a quiet lagoonal environment through storm action (Tables 1-3; Fig. 3-4).

\section{Biofacies 3}

Biofacies 3, deposited above Biofacies 2, reflected deposition in a marine to hypersaline, high energy sub-tidal environment.

\section{Lithology}

The sediments of the Biofacies 3 bearing intervals at all sites (Areas I9, I14, and TN1) were composed primarily of sand (Fig. 3-4). The lithology of the basal Biofacies 3 interval ( -140 to $-210 \mathrm{~cm}$ below MSL) in Area TN1 was characterized by a moderate to well-sorted sand. This sand was overlain by a framework supported rubble unit consisting of cobble to boulder-sized material with a matrix composed of moderate to well-sorted sand (Fig. 3-4). 
In Area I9 and Area I14, Biofacies 3 was found between 0 to $-121 \mathrm{~cm}$ and 0 to -164 $\mathrm{cm}$ below MSL respectively (Fig. 3-4). At the base of the Biofacies 3 interval in both areas (Area I9: -100 to $-121 \mathrm{~cm}$ below MSL; Area I14: -150 to $-164 \mathrm{~cm}$ below MSL) there was a significant silt/clay and organic matter component (Fig. 3-4).

The upper portion of the Biofacies 3 interval in Area I9 consists entirely of wellsorted sand. In Area I14, the -126 to $-150 \mathrm{~cm}$ below MSL interval was only moderately sorted, with a high silt/clay and organic matter component. However, the remaining portion ( 0 to $-126 \mathrm{~cm}$ below MSL) in Area I14 like Area I9 was composed of well-sorted sand (Fig. 3-4).

\section{Foraminifera}

The foraminiferal fauna in Biofacies 3 was characterized by a very high porcelaneous component (mean fractional abundance of 0.28 ) and faunal diversity (mean Fisher Index of 9.86) (Tables 1-3; Fig. 3-4). The high porcelaneous component and diversity indicated a subtidal marine to hypersaline environment (Murray, 1991). The generally abraded nature of all the foraminiferal tests also indicated a high energy environment. One anomalous sample at the top of the section in Area I9 (-10 to $-15 \mathrm{~cm}$ below MSL) lacked a porcelaneous fraction. Since this sample was close to mean sealevel, this sample may have been located in the upper shoreface where conditions were harsh and not conducive to the epifaunal lifestyle of the taxa in the porcelaneous fraction (Tables 3-1, 3-2 Fig. 3-4).

\section{Strontium Isotopic Data}

The foraminiferal analysis as described above, identified three distinct biofacies that were linked to salinity and oxygen variations within the three stratigraphic sections from the inner harbor at Caesarea. By combining various $\mathrm{Sr}$ isotopic analyses we were able to constrain the source of the freshwater creating the brackish water conditions in the inner 
harbor, and we were also able to determine salinity shifts at a higher resolution compared to the foraminiferal analysis. Coupled with the sedimentological evidence we were able to determine restrictive changes in the morphology of the inner harbor through time.

\section{Mixing Equation and Source of Freshwater}

The ${ }^{87} \mathrm{Sr} /{ }^{86} \mathrm{Sr}$ ratios of the various taxa from the three sections from the inner harbor exhibit a wide range of values (0.709041 to 0.709196; Table 3-4; Fig. 3-5) that are at or below the modern ${ }^{87} \mathrm{Sr} /{ }^{86} \mathrm{Sr}$ value for seawater $(0.70918)$. Since the preservation of the taxa was pristine (no diagenetic overprint), and since careful sample preparation minimized any potential contaminating effect, values different from the ${ }^{87} \mathrm{Sr} / 86 \mathrm{Sr}$ value for modern seawater may be interpreted as resulting from the freshwater dilution of seawater. The possible sources of freshwater for ancient Caesarea included groundwater and water from the aqueducts that originated from the springs in the Carmel Mountains.

The travertine samples from the aqueduct (AQ94/1, AQ94/2; Table 3-5), the Shuni Spring (C94/W3) in the Carmel Mountains and the groundwater (C94/W1) all had values lower than the ${ }^{87} \mathrm{Sr} /{ }^{86} \mathrm{Sr}$ value of seawater $(0.70918)$ which was a reflection of the older marine limestones (Cretaceous), marls (Pliocene) and sandstones (Pleistocene) aquifers that the waters were flowing through. The ${ }^{87} \mathrm{Sr} /{ }^{86} \mathrm{Sr}$ values of the travertine $(0.708048)$ and the modern Shuni Spring $(0.708511)$ are in reasonable agreement with each other considering that the ${ }^{87} \mathrm{Sr} /{ }^{86} \mathrm{Sr}$ composition of riverine water may vary considerably over time (i.e. Ganges ${ }^{87} \mathrm{Sr} /{ }^{86} \mathrm{Sr}$ varies $0.760-0.710$; Palmer and Edmond, 1989, 1992; Bryant et al., 1995). This close similarity indicates that the isotopic composition of the springs has not appreciably changed over the last $2000 \mathrm{yrs}$.

The predominant source of the freshwater affecting the ${ }^{87} \mathrm{Sr} / 86 \mathrm{Sr}$ values within the three sections in the inner harbor was groundwater. Using the two-component mixing equation normalized to salinity (Equation 3), only dilution by groundwater matched the ecological constraints of the foraminifera found within the sections (Murray, 1991; Fig. 3- 
6). The mixing curve using the ${ }^{87} \mathrm{Sr} /{ }^{86} \mathrm{Sr}$ and $\mathrm{Sr}$ concentration values from the Shuni Spring and modern seawater resulted in the majority of the salinities for the various taxa in the three studied sections (I9, I14, TN1) to range from 0 to 5 ppt (Fig. 3-6a). This salinity range was too low for the salinity requirements of the foraminiferal fauna found in the sections (Murray, 1991). In addition, the mixing curve for the travertine samples from the aqueduct, with their lower ${ }^{87} \mathrm{Sr} /{ }^{86} \mathrm{Sr}$ values, also indicated that the salinities did not match (Fig. 3-6b). The mixing curve produced with the ${ }^{87} \mathrm{Sr} /{ }^{86} \mathrm{Sr}$ and $\mathrm{Sr}$ concentration values for the groundwater and modern seawater produced salinities that were within the ecological constraints of the foraminifera, with the majority of the salinity values ranging from 10 to $25 \mathrm{ppt}$ (Fig. $3-6 \mathrm{c}$ ). In addition, the lowest reported ${ }^{87} \mathrm{Sr} / 86 \mathrm{Sr}$ value from all the taxa analyzed was from the predominantly brackish water ostracods $(0.709041$; Cyprideis sp.) which was identical within uncertainty to the groundwater value (0.709053; Table 3-4). The resolution offered by our mixing curve for salinity determinations was due primarily to the high concentration of $\mathrm{Sr}(3.37 \mathrm{ppm})$ in the groundwater (Table 3-5). The level of $\mathrm{Sr}$ in the groundwater was much higher than reported riverine values. However, very little comparative information on the $\mathrm{Sr}$ concentrations in groundwater is available (Chauduri and Clauer, 1986; Palmer and Edmond, 1989, 1992). We are confident that our value was not contaminated by marine waters since the measured salinity of the groundwater was less than $1 \mathrm{ppt}$. The high levels of Sr were probably due to the dissolution of the Quaternary carbonate rich sandstone (kurkar) in the coastal plain that are very porous and permeable and very good aquifers (Neev et al., 1987; Issar, 1990).

Dilution by groundwater influx into the modern harbor environment is also evident. The ${ }^{87} \mathrm{Sr} /{ }^{86} \mathrm{Sr}$ value for the seawater sample collected from modern inner harbor was 0.709148 (C94/W2) which, if analytical uncertainty is considered $\left(2 \times 10^{-5}\right)$, is not significantly different from the global ${ }^{87} \mathrm{Sr} / 86 \mathrm{Sr}$ value $(0.70918$; Table $3-5)$. However, the $\mathrm{Sr}$ concentration of the seawater sample was lower by $25 \%(6.03 \mathrm{ppm})$ than the standard concentration of $\mathrm{Sr}$ in the modern oceans (8 ppm; Carmichael, 1982). The 
${ }^{87} \mathrm{Sr} / 86 \mathrm{Sr}$ value of 0.709148 yielded a salinity value of $22 \mathrm{ppt}$ from the mixing curve and it could range from 15 to $32 \mathrm{ppt}$ with analytical uncertainty. However, the foraminiferal sample from the upper sedimentary unit in Area TN1, deposited in a high energy marine environment similar to the modern environment, was also slightly lower at 0.709152 suggesting that the ${ }^{87} \mathrm{Sr} /{ }^{86} \mathrm{Sr}$ value was in fact lower. This data from the modern seawater values may suggest that there is significant groundwater flow into the modern inner harbor that affects the local ${ }^{87} \mathrm{Sr} /{ }^{86} \mathrm{Sr}$ ratio of the seawater.

Using the mixing equations to derive salinity measurements depends upon several factors that can limit its use. Our mixing model required that the ${ }^{87} \mathrm{Sr} / 86 \mathrm{Sr}$ value and the $\mathrm{Sr}$ concentration from the modern groundwater did not differ from values in the past (last $2000 \mathrm{yrs})$. Our ${ }^{87} \mathrm{Sr} /{ }^{86} \mathrm{Sr}$ value from the freshwater to brackish water ostracods and its very close agreement with the groundwater ${ }^{87} \mathrm{Sr} /{ }^{86} \mathrm{Sr}$ value suggested that the values have remained constant within the resolution of the method during the period in question.

\section{Micropaleontological / Strontium Isotopic Paleoenvironmental}

\section{Interpretation}

The ${ }^{87} \mathrm{Sr} /{ }^{86} \mathrm{Sr}$ values of the various taxa found in the three sections from the inner harbor, and calculated salinities, were highly variable from sample to sample and within the same unit (Table 3-4; Fig. 3-5). A very surprising result is the degree of variation found within the different taxa from the same sample horizon. For example, Area I14 (164-166 cm below MSL) had ${ }^{87} \mathrm{Sr} /{ }^{86} \mathrm{Sr}$ values that ranged from 0.709041 to 0.709119 . This corresponded to a salinity range of 0 to $17 \mathrm{ppt}$ when analytical uncertainty was considered (Table 3-4; Fig. 3-5). Since only taphonomically pristine specimens were selected for analysis (indicating limited reworking), the variation between taxa within the same sample horizon suggests that the taxa existed in an environment of highly variable salinity.

The ${ }^{87} \mathrm{Sr} /{ }^{86} \mathrm{Sr}$ values from the sample horizons that were designated as Biofacies 1 based on the foraminiferal data all indicate lower salinity conditions with possibly some 
higher salinity intervals (Table 3-4; Fig. 3-5). The samples from Area I14 indicated salinity levels that ranged from around 11 to 27 ppt. However, one sample towards the base of the section (255-257 cm below MSL) showed a normal marine ${ }^{87} \mathrm{Sr} /{ }^{86} \mathrm{Sr}$ value (Table 3-4; Fig. 3-5). Similarly, the values from the Biofacies 1 interval in Area I9 displayed lower salinity levels which ranged from 5 to $25 \mathrm{ppt}$ when analytical uncertainty was considered $\left( \pm 2 \times 10^{-5}\right)$. The samples from Area TN1 had lower salinity values from the other two sections, varying from 4 to $12 \mathrm{ppt}$.

The low salinity conditions were in keeping with the foraminiferal biofacies analysis and the corresponding environmental interpretation. However, one marine dominated sample interval from the base of the section at I14 also indicated dramatically fluctuating salinities within this unit. The low oxygen conditions probably played a large role in keeping diversity low and preventing colonization by miliolids. The ${ }^{87} \mathrm{Sr} / 86 \mathrm{Sr}$ values of Biofacies 1 samples from Area TN1 indicated lower salinity conditions relative to Areas I9 and I14 which contrasted with our original foraminiferal interpretation that suggested higher salinity conditions compared to these other sections (Table 3-4; Fig. 3-4, 3-5). However, this environment was not dominated by bolivinid-type genera which are indicative of better oxygenation. The hypoxia conditions in Biofacies 1 of the I9 and I14 sections must have had a large effect on the foraminiferal distribution.

Biofacies 2 was characterized by highly variable salinity conditions. This is exemplified in Area I14 by the sample interval $164-166 \mathrm{~cm}$ below MSL which as mentioned previously, varied from 0 to $17 \mathrm{ppt}$ (Table 3-4; Fig. 3-5). The highly variable salinity conditions are in keeping with the foraminiferal interpretation which suggested increased influx of marine water. However, the foraminiferal fauna also suggested an increased salinity with the appearance of a significant porcelaneous population. The ${ }^{87} \mathrm{Sr} / 86 \mathrm{Sr}$ values, although highly variable, seem to indicate a slight reduction in salinity from conditions during deposition of Biofacies 1 (Table 3-4; Fig. 3-5). The lower salinities and their dramatic fluctuations within Biofacies 2 suggest either a more restricted 
environment with increased periodic influx of marine waters or increased groundwater flow into the inner harbor.

The foraminiferal fauna and sedimentology of Biofacies 3 indicated a normal salinity and high water energy subtidal environment. However, the ${ }^{87} \mathrm{Sr} /{ }^{86} \mathrm{Sr}$ values of the various taxa within this biofacies were not indicative of a normal salinity environment (Table 3-4; Fig. 3-5). The ${ }^{87} \mathrm{Sr} / 86 \mathrm{Sr}$ values were equally as variable as those in Biofacie 2 but leaned to slightly elevated salinity levels which varied from 3 to $35 \mathrm{ppt}$. This suggested periods when the area consisted of restricted pools of brackish water. These could have been created by shifting sandbars or berms. The abundant small (approximately $1 \mathrm{~mm}$ in diameter) articulated bivalves in certain horizons suggested periods of lower water energy, and the cerithid gastropods found here, typical of euryhaline environments, reinforced this interpretation. The high groundwater level in the modern inner harbor sediments (approximately $0.5 \mathrm{~m}$ above MSL) indicated that pools of water formed by berms or sandbars were dominated by groundwater. The low ${ }^{87} \mathrm{Sr} / 86 \mathrm{Sr}$ values of the miliolids (Massilina gualtierana) was contrary to our original Biofacies 3 interpretation since Massilina gualtierana appears to be able to tolerate a wider range of salinities.(Table 3-4; Fig. 3-5).

\section{DISCUSSION}

The eastern Mediterranean at present experiences more evaporation than precipitation resulting in high surface water temperatures and hypersalinity (Emelyanov and Shinkus, 1986). Consequently, one would expect conditions within the inner portions of a restricted harbor in the eastern Mediterranean such as the one at Caesarea to be hypersaline. However, the foraminiferal faunas, and the ${ }^{87} \mathrm{Sr} /{ }^{86} \mathrm{Sr}$ values within the sections from Area TN1, Area I9, and Area I14, all located within the inner harbor, indicated deposition in a brackish water environment. 
Accounting for this evidence of brackish water conditions in the inner harbor required consideration of the sources of fresh water. Throughout Caesarea's history, aqueducts were constructed to transport water from springs in the Carmel mountains to the city (Olami and Peleg, 1977; Raban, 1989). In addition, the city itself had many wells and cisterns, and was known for its elaborate sewer system, as clearly described by authors in antiquity (Raban, 1989). Modern excavations of the inner harbor have also uncovered evidence of a significant freshwater ground water table at approximately $50 \mathrm{~cm}$ above MSL (Raban, 1996). As our ${ }^{87} \mathrm{Sr} / 86 \mathrm{Sr}$ data has shown the majority of freshwater came from this groundwater, with probably smaller contributions from precipitation runoff and from sewer systems.

In order to obtain the necessary salinity shifts found in the sections from the inner harbor, some form of restricting barrier was required. The modern, relatively open, inner harbor appeared to be affected by high groundwater flow although not to the same degree as noted in the three stratigraphic sections. Assuming that groundwater flow has not changed greatly, the magnitude of the observed salinity shifts within the sections from the inner harbor indicated some form of restriction. The assumption that groundwater flow has not changed over time is not necessarily valid since there is evidence of a climatic change towards more arid conditions around $600 \mathrm{AD}$. Unfortunately, the magnitude of this change on the groundwater flow is hard to estimate, however there has been found to be little variation in the groundwater level in ancient wells in the coastal plain during historic times (Nir and Eldar, 1987). Our interpretation that the salinity shifts were representative of more restricted conditions is supported by the sedimentological evidence (deposition silts/clays and organic matter) found in the sections. Any temporal climate induced changes in the groundwater flow in the inner harbor would probably be overprinted by morphological changes, both anthropological and natural, which altered the inner harbor.

Based on the pottery dates and the sedimentological, micropaleontological, and isotopic evidence it appears that the inner confine of the harbor (Area I9 and Area I14) was 
a restricted brackish environment in at least the $1 \mathrm{st} \mathrm{c}$. $\mathrm{AD}$ and ranging to the 5 th $\mathrm{c} . \mathrm{AD}$ (Raban, 1996; Raban et al., 1997a,b; Yule and Barham, 1997; Figs. 3-4, 3-7 c,d,e,f). However, the basal unit that contained the 1 st $-2 \mathrm{nd}$ c. AD pottery was thin and not laterally extensive, suggesting that there may be a significant hiatus in deposition from the top of this unit (top of interval -265 to $-280 \mathrm{~cm}$ below MSL) and the overlying high organic unit of the 3rd to 5th c. AD (bottom of interval -162 to $-265 \mathrm{~cm}$ below MSL) in Area I9 (Fig. 34). In Area I14 there was no evidence of deposits prior to the 4th c. AD, although the basal sand unit (-260 to $-270 \mathrm{~cm}$ below MSL) might be older (Yule and Barham, 1997). This hiatus might have been caused by the removal of sediment through dredging activity, or by the lack of deposition due to a sluicing current. However, because the basal sand units do not contain any significant organic matter does suggest that the portion of the inner harbor covered by Areas I9 and I14 was a restricted but relatively well circulated brackish water environment at least in the $1 \mathrm{st} \mathrm{c}$. $\mathrm{AD}$ and probably up to the $3 \mathrm{rd} \mathrm{c}$. $\mathrm{AD}$ (Fig. 3-7 c,d). It also appears that there were periods of higher salinity as evidenced by the ${ }^{87} \mathrm{Sr} / 86 \mathrm{Sr}$ data in the basal portion of Area I14.

The increase in the silt/clay and organic matter content of the sediments (from the basal sands) in Area I9 and Area I14 suggested that there was a shift towards a more restricted and stagnant environment, and active dumping of human refuse (Raban, 1996; Raban et al., 1997a,b; Yule and Barham, 1997; Figs. 3-5, 3-7e, f). The highly restricted environment may have reflected the development of sand bars which further restricted the inner harbor to form a localized lagoon sometime during the 3rd c. AD (Biofacies 1; Raban, 1996; Fig. 3-7e). Based on archaeological evidence this incursion of sand probably started in the $2 \mathrm{nd} \mathrm{c}$. $\mathrm{AD}$ and developed due to the destruction of the main harbor breakwaters (Fig. 3-7d). This resulted in a higher energy environment allowing the influx of sand. This lagoon became probably more restricted and brackish with variable salinities (based on the ${ }^{87} \mathrm{Sr} / 86 \mathrm{Sr}$ data) during the deposition of Biofacies 2 , and began to shoal and be breached 
on a regular basis by marine waters, perhaps as storm overwash deposits (Biofacies 2; Area I14 and Area I9) sometime by the 5th c. AD (Fig. 3-7f).

The overlying well sorted sands (Biofacies 3) from Area I14 (0 to $-164 \mathrm{~cm}$ below MSL) and Area I9 (0 to $-120 \mathrm{~cm}$ below MSL) are typical of a high-energy subtidal environment and are evidence of continued infilling with overwash deposits of the previously organic matter dominated lagoon (Biofacies 2; Fig. 3-4). This sand interval that has pottery dates from the 5th, 6th and 7th c. AD marked the complete infilling of the inner harbor (Raban, 1996; Raban et al., 1997; Yule and Barham, 1997; Fig. 3-4). However, the pottery in this interval was generally rounded and eroded, suggesting that the sands could be much younger than indicated by the pottery dates (deposited perhaps during or after the 7 th c. $\mathrm{AD}$ ). The ${ }^{87} \mathrm{Sr} / 86 \mathrm{Sr}$ data also suggested a continued freshwater influence (Fig. 3-5). The brackish water conditions indicated the continued presence of a sand barrier forming brackish water pools within the sands that likely shifted on a regular basis due to reworking during storms (Fig. 3-7g). Some layers of higher organic sands with trace fossils were evident within the basal portions of Biofacies 3 in Area I14 which suggested periods of sediment stability. The sediments continued to accrete to sealevel within the inner harbor, fully land locking the area probably by the mid-8th $\mathrm{c}$. AD (Raban, 1996).

Area TN1 documented the depositional history of the more seaward portion of the inner harbor. The basal silt/clay unit (-260 to $-270 \mathrm{~cm}$ below MSL) may have been created by deposition prior to the 6 th $\mathrm{c}$. $\mathrm{AD}$ with the abrupt contact between the underlying silt/clay unit and the overlying high pottery concentration (late 6 th to early 7 th c. $\mathrm{AD} ;-220$ to -260 $\mathrm{cm}$ below MSL), possibly indicative of a significant depositional hiatus or erosional surface. However, the silt/clay unit had the same consistency and color as the mud matrix in the pottery concentration, the same foraminiferal distribution and similar ${ }^{87} \mathrm{Sr} / 86 \mathrm{Sr}$ ratios which suggested that the two units represented continuous sedimentation. The pre 6th-7th c. AD deposits must have been removed through dredging activity. The high 
concentration of angular pottery in this layer, as well as the surrounding mud/silt matrix, the foraminiferal fauna (Biofacies 1), and the ${ }^{87} \mathrm{Sr} /{ }^{86} \mathrm{Sr}$ data all indicated that this part of the harbor was a restricted, groundwater fed, brackish water environment sometime during the 6th-7th c. AD (Fig. 3-7f, g). However, the evidence for a quiet water state into the late 6th to early 7 th c. $\mathrm{AD}$ is environmentally inconsistent with the high energy beach deposits (late 6th- early 7th c. AD) in Area I9 and Area I14. The dates from Area TN1 were also inconsistent with the dates of the silt/clay organic matter units (Biofacies 1) in Area I9 and Area 114 (4th-5th c. AD and 3rd-5th c. AD) since sediments from the the 6th-7th c. AD were not present. At this time the inner portion of the harbor represented by Areas I9 and I14 was probably unusable, having filled in with sand from the south and west. A renovation that may have involved the emplacement of a sea wall and/or dredging may have been an attempt to extend the life of the inner harbor (perhaps by Anastasius I in $500 \mathrm{AD}$ ) and Area TN1 was the location of the harbor activity in the 6th and 7th c. AD. The overlying, poorly-sorted rubble unit may have been deliberately dumped into the harbor by Arab occupants to prevent seaborne invasions of the Byzantine naval fleet in the later part of the 7th c. AD (Raban, 1996; Raban et al., 1997a).

The implications of a high groundwater flow into the Herodian inner harbor have not been considered previously. There is archaeological evidence of sluicing channels that operated within the inner harbor that would have channeled seawater into the harbor, increasing the amount of water in the basin, and creating a current flowing out of the entrance that would keep the harbor silt-free (Raban, 1996). However, the large influx of freshwater into the inner harbor would also have had this same effect and the water would also be silt and sediment free. The influx of water into a contained area would cause a net outflow out of both the inner harbor and out of the harbor in general thereby aiding in the production of a sluicing current. 


\section{CONCLUSIONS}

Foraminiferal and strontium isotope analysis of Areas TN1, I14 and I9 has enhanced the archaeological interpretation of the inner harbor at Caesarea. The Sr isotopic analysis of the potential sources of freshwater (aqueduct and groundwater) and the foraminifera contained in the deposits from the inner harbor, has determined the primary source of freshwater flowing into the ancient harbor. In addition, the combined micropaleontological and strontium isotope analysis has documented high resolution salinity changes within the inner harbor from its inception in the $1 \mathrm{st} \mathrm{c}$. $\mathrm{AD}$ to its demise sometime during or after the 7 th $\mathrm{c}$. AD. The brackish water environment was the product of both the influx of freshwater and some form of restricting barrier which was initially provided by the harbor breakwaters and, later, by sand bars. In the functioning harbor, the high freshwater influx would have created a current outflowing from the inner harbor, aiding the sluicing system, and helping to prevent silting. The complete silting and decline of the inner harbor occurred sometime during or after the 7 th $\mathrm{c}$. AD as evidenced by the sedimentological and micropaleontological data.

This study has also demonstrated the effectiveness of a combined micropaleontological/strontium isotope methodology as a high resolution paleosalinity proxy in the analysis of coastal lagoonal environments. The combined micropaleontological/strontium isotope research on the inner harbor at Caesarea has recognized changes in the restriction of a human-built lagoonal environment. However, the combined methodology could be equally used in studies on naturally formed coastal lagoon environments to determine changes in restriction and possibly climatic variation through changes in the influx of freshwater. This research has also emphasized again the importance of micropaleontological and isotopic techniques for the interpretation of coastal marine archaeological deposits. 


\section{ACKNOWLEDGMENTS}

Research was partially supported by Natural Sciences and Engineering Research Council of Canada Research Grant to RTP (OGP0041665) and research funds provided by J.B. We would like to thank the Center for Maritime Studies (University of Haifa, Israel) for providing logistical support and to the volunteers of the Combined Caesarea Excavations who devoted their time and energy to the underwater excavations. We would also like to thank H. C. Devine who improved the written text. 


\section{REFERENCES}

Brandon C. (1996) Cements, Concrete, and Settling Barges at Sebastos: Comparisons with other Roman Harbor Examples and the Descriptions of Vitruvius. In Caesarea Maritima; A Retrospective after Two Millennia (ed. Raban A. and Holum K.G.) pp. 25-40. Alladin Press.

Broecker W.S. (1963) Radioisotopes and large-scale oceanic mixing. In The Sea (ed. M.N. Hill) pp. 88-108. Interscience.

Bryant J.D., Jones D.S., and Mueller P.A. (1995) Influence of freshwater flux on ${ }^{87} \mathrm{Sr} /{ }^{86} \mathrm{Sr}$ chronostratigraphy in marginal marine environments and dating of vertebrate and invertebrate faunas. J. Paleont. 69, 1-6.

Burke W.H., Denison R.E., Hetherington E.A., Koepnick R.B., Nelson H.F. and Otto J.B. (1982) Variation of ${ }^{87} \mathrm{Sr} / 86 \mathrm{Sr}$ throughout Phanerozoic time. Geology 10, 516-519.

Carmichael R.S. (1982) Handbook of Physical Properties of Rocks. Vol. 1, CRC Press, Inc.

Chauduri S. and Clauer N. (1986) Fluctuations of isotopic composition of strontium in seawater during the Phanerozoic Eon. Chemical Geology (Isotope Geoscience Section), 59, 293-303.

Culver S.J. (1993) Foraminifera. In Fossil Prokaryotes and Protists (ed. J.H. Lipps) pp. 203-247. Boston. 
DePaolo D.J. and Ingram B. (1985) High Resolution stratigraphy and strontium isotopes. Science 227, 938-941.

Dodd J.R. and Stanton R.J. (1990) Paleoecology; Concepts and Applications. John Wiley and Sons.

Edmond J.M. (1992) Himalayan tectonics, weathering processes, and the strontium isotope record in marine limestones. Science 258, 1594-1597.

Emelyanov, E.M. and Shinkus K.M. (1986) Geochemistry and Sedimentology of the Mediterranean Sea. Reidel.

Farrell J.W., Clemens S.C., and Gromet L.P., (1995) Improved chronostratigraphic reference curve of late Neogene seawater. Geology 23, 403-406.

Faure G.(1986) Isotope Geology. John Wiley and Sons.

Fedje D.W. (1993) Sea-Levels and Prehistory in Gwaii Haanas . Unpublished Master's thesis, Department of Archaeology, Univ. of Calgary.

Harris N. (1995) Significance of weathering Himalayan metasedimentary rocks and leucogranites for the Sr isotope evolution of seawater during the early Miocene. Geology 23, 795-798. 
Hodell D.A., Mead G.A., and Mueller P.A. (1990) Variation in the strontium isotopic composition of seawater ( $8 \mathrm{Ma}$ to present): implications for chemical weathering rates and dissolved fluxes to the oceans. Chem. Geol. 80, 291-307.

Hohlfelder R.L. (1985) Byzantine coin finds from the sea: A glimpse of Caesarea Maritima's later history. In Harbor Archaeology, B.A.R. International Series, (ed. A. Raban), Vol. 257, pp. 179-184. Oxford.

Hohlfelder R.L. (1988) Procopius' De Aedifiis 1.11, 1820: Caesarea Maritima and the building of harbours in late antiquity. Mediterranean Historical Review 3, 54-62.

Holum K.G., Hohfelder R.L., Bull R.J., and Raban A. (1988) King Herod's Dream: Caesarea on the Sea. W.W. Nortan \& Company.

Ingram B.L.and Sloan D. (1992) Strontium isotopic Composition of Estuarine Sediments as Paleosalinity-Paleoclimate Indicator. Science $\mathbf{2 5 5}$, 68-72.

Issar A.S. (1990) Water Shall Flow From the Rock. Springer Verlag.

Mart Y. and Perecman I. (1996) Caesarea: Unique evidence for faulting patterns and sea level fluctuations in the late Holocene. In Caesarea Maritima; A Retrospective after Two Millennia (ed. A. Raban A. and K.G. Holum) pp. 3-24. Alladin Press.

McArthur J.M. (1994) Recent trends in strontium isotope stratigraphy. Terra Nova 6, 331-358. 
Miller, A.A.L., Scott D.B., and Medioli F.S. (1982) Elphidium excavatum (Terguem); ecophenotypic versus suspecific variation. J. of Foram. Res. 12, 116-144.

Murray J.W. (1991) Ecology and Palaeoecology of Benthic Foraminifera. Longman Group UK Limited.

Neev D., Bakler N., and Emery K.O. (1987) Mediterranean Coasts of Israel and Sinai. Taylor \& Francis.

Nir Y. and Eldar I. Ancient Wells and Their Geoarchaeological Significance in Detecting Tectonics of the Israel Mediterranean Coastline Region. Geology 15, 3-6.

Olami Y. and Peleg Y. (1977) The water supply system of Caesarea Maritima. The Israel Exploration Journal 27, 127-137.

Oleson J.P., Hohlfelder R.L., Raban A., and Vann R.L. (1984) The Caesarea ancient harbor excavation project (CAHEP): preliminary report on the 1980-1983 seasons. Journal of Field Archaeology 11, 281-305.

Patterson R.T. and Fishbein E. (1989) Re-examination of the statistical methods to determine the number of point counts needed for micropaleontological quantitative research. J.Paleontol. 63, 245-248.

Patterson R.T., Blenkinsop J., and Cavazza W. (1995) Planktic foraminiferal biostratigraphy and ${ }^{87} \mathrm{Sr} / 86 \mathrm{Sr}$ isotopic stratigraphy of the Oligocene-to-Pleistocene sedimentary sequence in the southeastern Calabrian microplate, southern Italy. $J$. Paleont. 69, 7-20. 
Palmer M.R. and Edmond J.M. (1989) The Strontium isotopic budget of the modern ocean. Earth and Planet. Sci. Lett., 92, 11-26.

Palmer M.R. and Edmond J.M. (1992) Controls over the strontium isotope composition of river water. Geochim. Cosmochim. Act a 56, 2099-2111.

Paytan A., Kaster M., Martin E.E., Macdougall J.D., and Herbert T. (1993) Marine barite as a monitor of seawater strontium isotope composition. Nature $366,445-449$.

Pichler T. and Dix G.R. (1996) Hydrothermal venting within a coral reef ecosystem, Ambitle island, Papua New Guinea. Geology 24, 435-438.

Poag C.W. (1981) Ecological Atlas of Benthic Foraminifera of the Gulf of Mexico. Woods hole.

Raban A. (1989) Volume 1: The Site and Excavations: The Harbours of Caesarea Maritima: Results of the Caesarea Ancient Harbour Excavation Project, parts i \& ii, 19801985. In B.A.R. International Series (ed. J.P. Oleson) Vol. 491.

Raban A. (1991) Sebastos: The royal harbour at Caesarea Maritima — a short-living giant. Thracia Pontica IV, Sozopol.

Raban A. (1992) Sebastos: The royal harbour at Caesarea Maritima - a short-lived giant. The International Journal of Nautical Archaeology 21, 111-124. 
Raban A. (1994) Sebastos, The Herodian Harbour of Caesarea: Construction and Operation. Sefunim III,45-59.

Raban A. (1995) Sebastos: The Royal Harbour of Herod at Caesarea Maritima: 20 Years of Underwater Research. Marinarkeologisk Tidskrift I, 9.

Raban, A. (1996) The Inner Harbor Basin of Caesarea: Archaeological Evidence for Its Gradual Demise. In Caesarea Maritima; A Retrospective after Two Millennia (ed. A. Raban and K.G. Holum) pp. 628-666. Alladin Press.

Raban A. and Hohlfelder R.L. (1981) The ancient harbors of Caesarea Maritima. Archaeology 34, 56-60.

Raban A. and Holum K.G. (1996) Caesarea Maritima; A Retrospective after Two Millennia. Alladin Press.

Raban A., Reinhardt E., McGrath M., and Hodge, N. (1997a) The Underwater Excavations 1993-1994. In Caesarea Papers II: (ed. K.G. Holum, A. Raban and J. Patrich), Journal of Roman Archaeology, supplementary series.

Raban A., Tuegg R., Yankelevitz S., and Arnon Y. (1997b) The Land Excavations in the Inner Harbour 1993-1994. In Caesarea Papers II:, (ed. K.G. Holum, A. Raban and J. Patrich), Journal of Roman Archaeology, supplementary series.

Reinhardt E.G., Patterson R.T., and Schröder-Adams C. (1994) Geoarchaeology of the ancient harbor site of Caesarea Maritima Israel: evidence from Sedimentology and Paleoecology of Benthic Foraminifera. J. Foram. Res. 24, 37-49. 
Reinhardt E.G., Easton, N.A., and Patterson, R.T.(1996) Foraminiferal evidence of late Holocene sea-level change and Amerindian site distribution at Montague Harbour. Géographie physique et Quaternaire 50, 35-46.

Reinhardt E.G., Patterson R.T. and Blenkinsop J. (1996) Testing for a Strontium Isotope (87Sr/86Sr) Vital Effect: A negative response from modern taxa found on Lee Stocking Island, Bahamas. see this volume.

Schmitz B., Åberg G., Werdelin L., Forey P., and Bendix-Almgreen S. E. (1991) ${ }^{87} \mathrm{Sr} / 86 \mathrm{Sr}, \mathrm{Na}, \mathrm{F}, \mathrm{Sr}$ and $\mathrm{La}$ in skeletal fish debris as a measure of the paleosalinity of fossil-fish habitats. Geol. Soc. of Amer. Bull. 103, 786-794.

Sen Gupta B.K. and Machain-Castillo M.L. (1993) Benthic foraminifera in oxygen-poor habitats. Mar. Micropaleontology 20, 187-193.

Veizer J. (1983) Trace Elements and Isotopes in Sedimentary Carbonates. In Carbonates: Mineralogy and Chemistry (ed. R.J. Reeder) Vol. 11, Chap. 8, pp. 265-299.

Williamson V.D. (1994) Preliminary Sedimentological Assessment of Samples from the Inner Harbour at Caesarea Maritima and Recommendations for Future Work. GSF Technical Report. University College London.

Yule B. and A.J. Barham (1997) Caesarea's inner harbour: the potential of the harbour sediments. In Caesarea Papers II:, (eds. K.G. Holum, A. Raban, and J. Patrich), Journal of Roman Archaeology, supplementary series. 
Yule B. and Rowsome P. (1994) Caesarea Maritima: Area I14 Excavations — the 1993

Season. Interim report on the excavation of a sondage through sediments filling the Herodian Inner Harbour, and an overlying Arab and Crusader sequence. Unpublished report.

Zhang J. and Scott D.B. (1996) Messinian deep-water turbidites and glacioeustatic sealevel changes in the North Atlantic: Linkage to the Mediterranean Salinity Crisis. Paleoceanography 11, 277-297. 
Fig. 3-1. Modern representation of the ancient harbor complex, showing the location of the submerged harbor moles and the modern breakwaters (after Holum et al., 1988). 


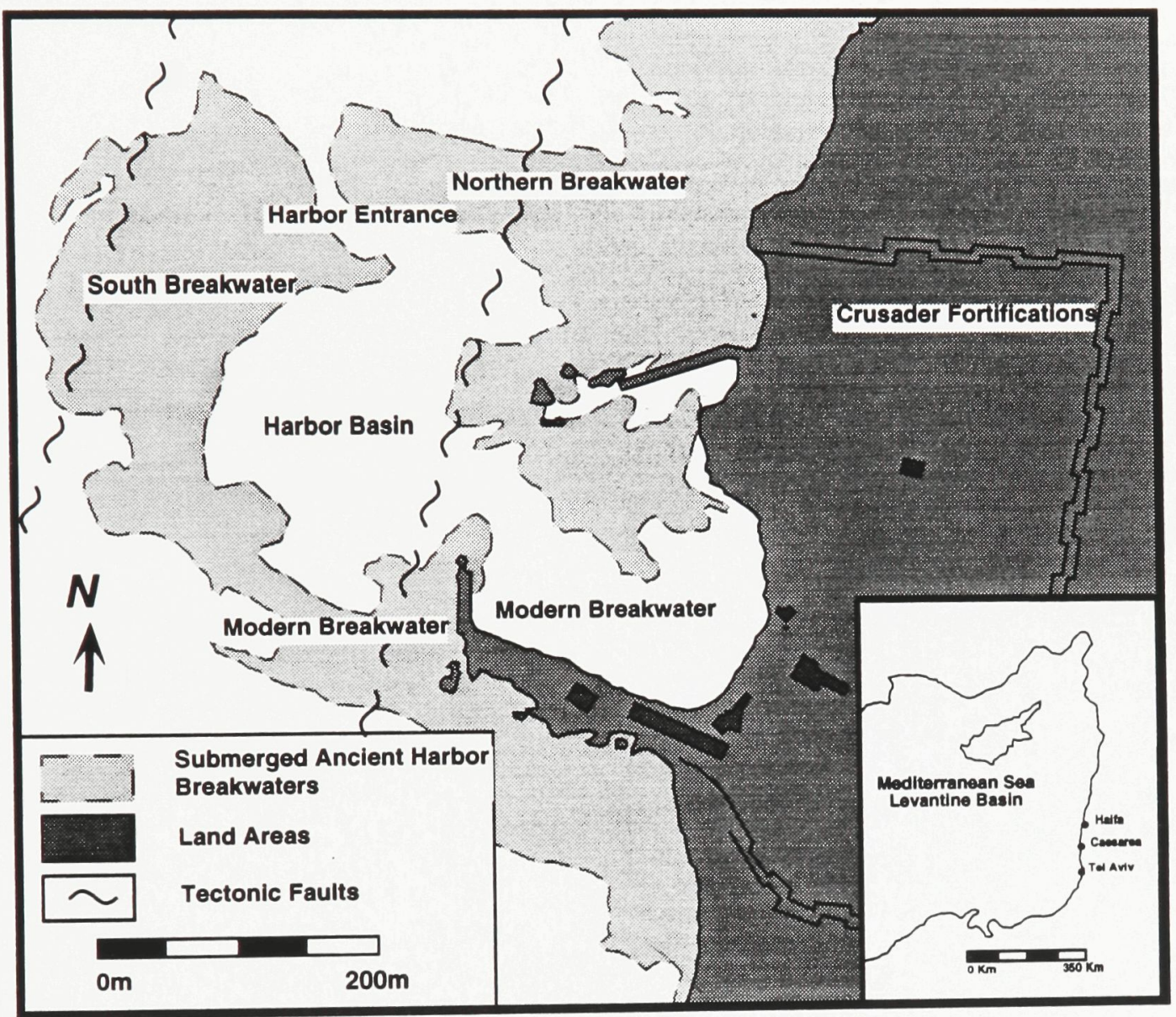


Fig. 3-2. Representation of the probable configuration of Herod's harbor based on archaeological evidence (after Raban and Holum, 1996). 


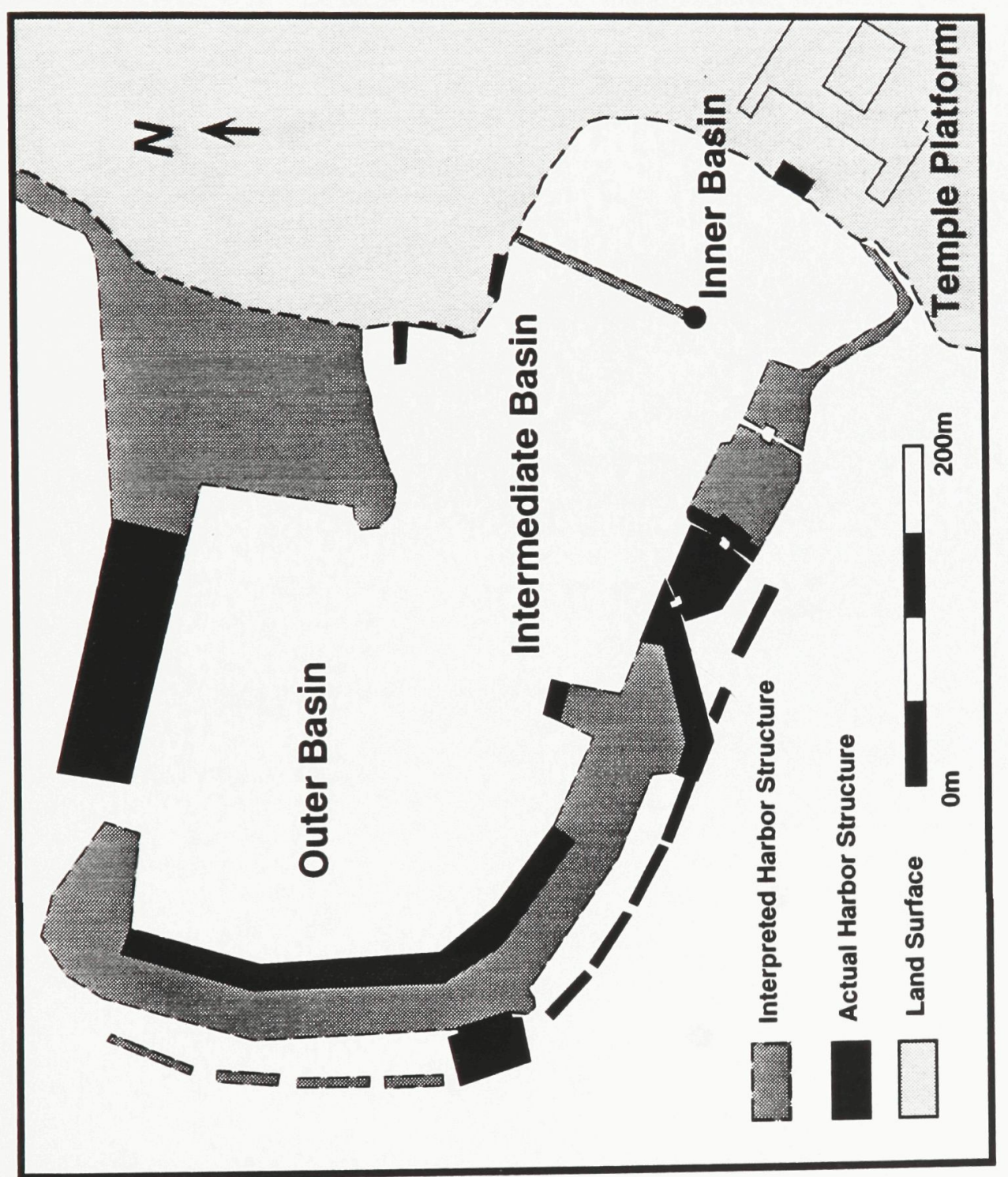


Fig. 3-3. Detail map of the modern inner harbor showing the location of the three excavation areas. 


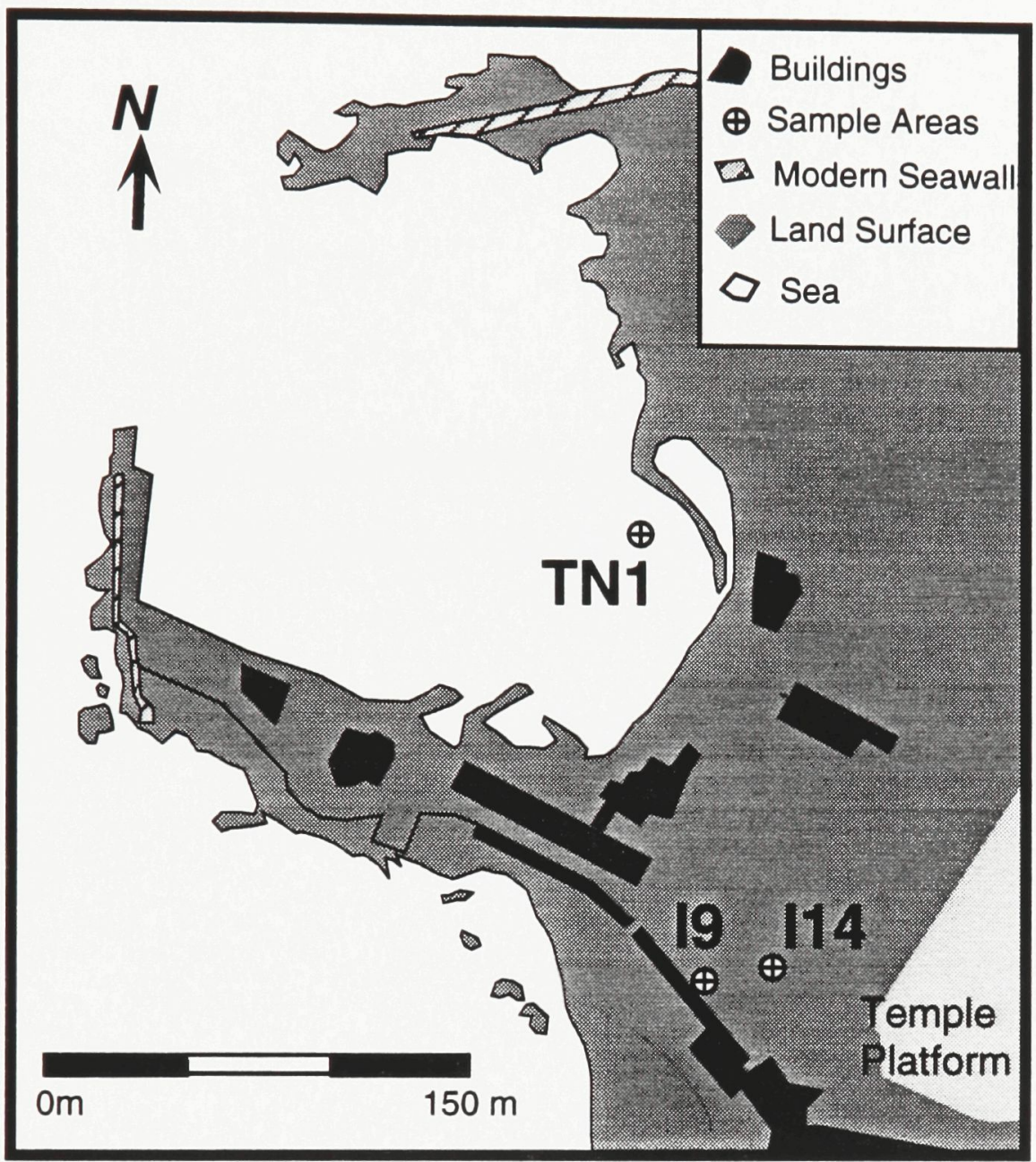


Fig. 3-4. Stratigraphic representation of the three excavation areas analyzed showing lithological, biofacies and pottery age distributions. 

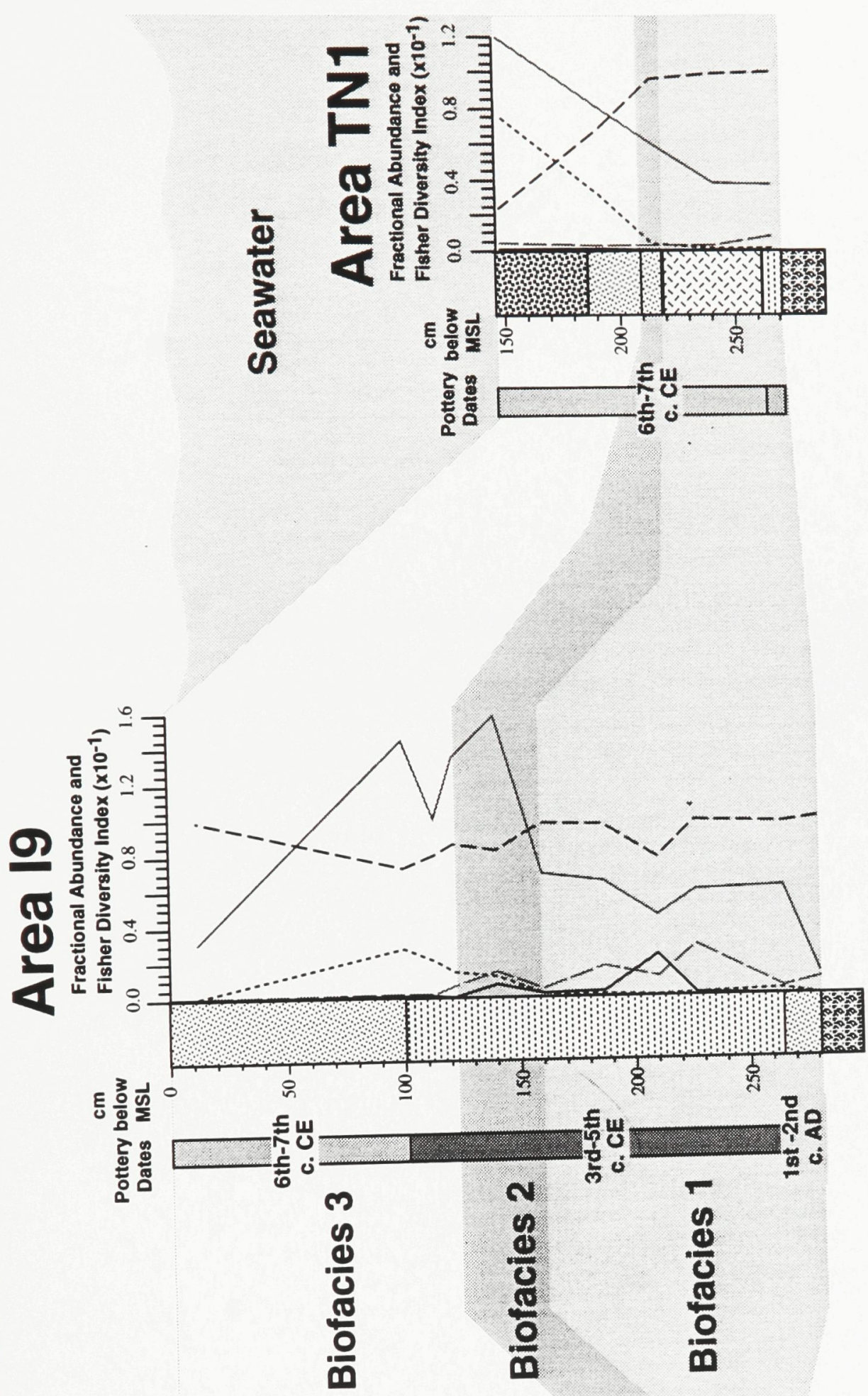

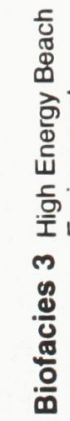

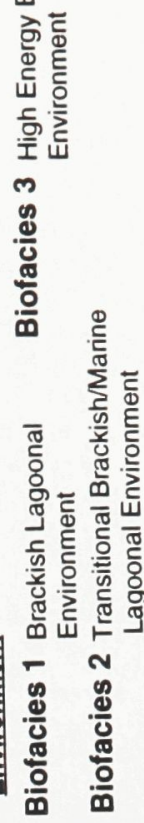

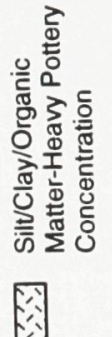

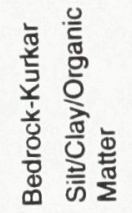

閣
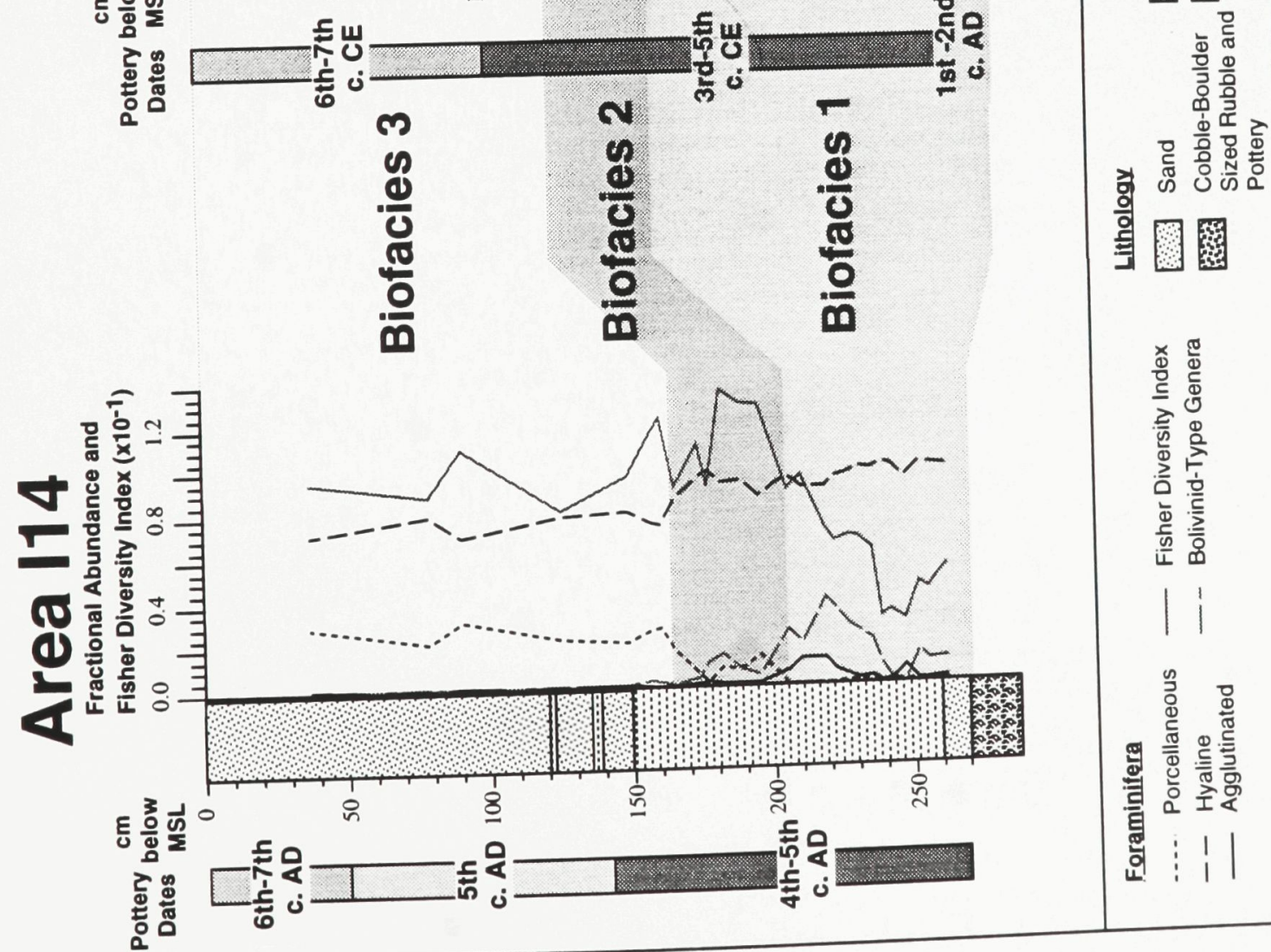
Fig. $3-5 .{ }^{87} \mathrm{Sr} /{ }^{86} \mathrm{Sr}$ determinations from the six different fossil taxa and the salinity determinations for the three excavation areas. Rectangles represent the $95 \%$ confidence interval for the ${ }^{87} \mathrm{Sr} / 86 \mathrm{Sr}$ values. 

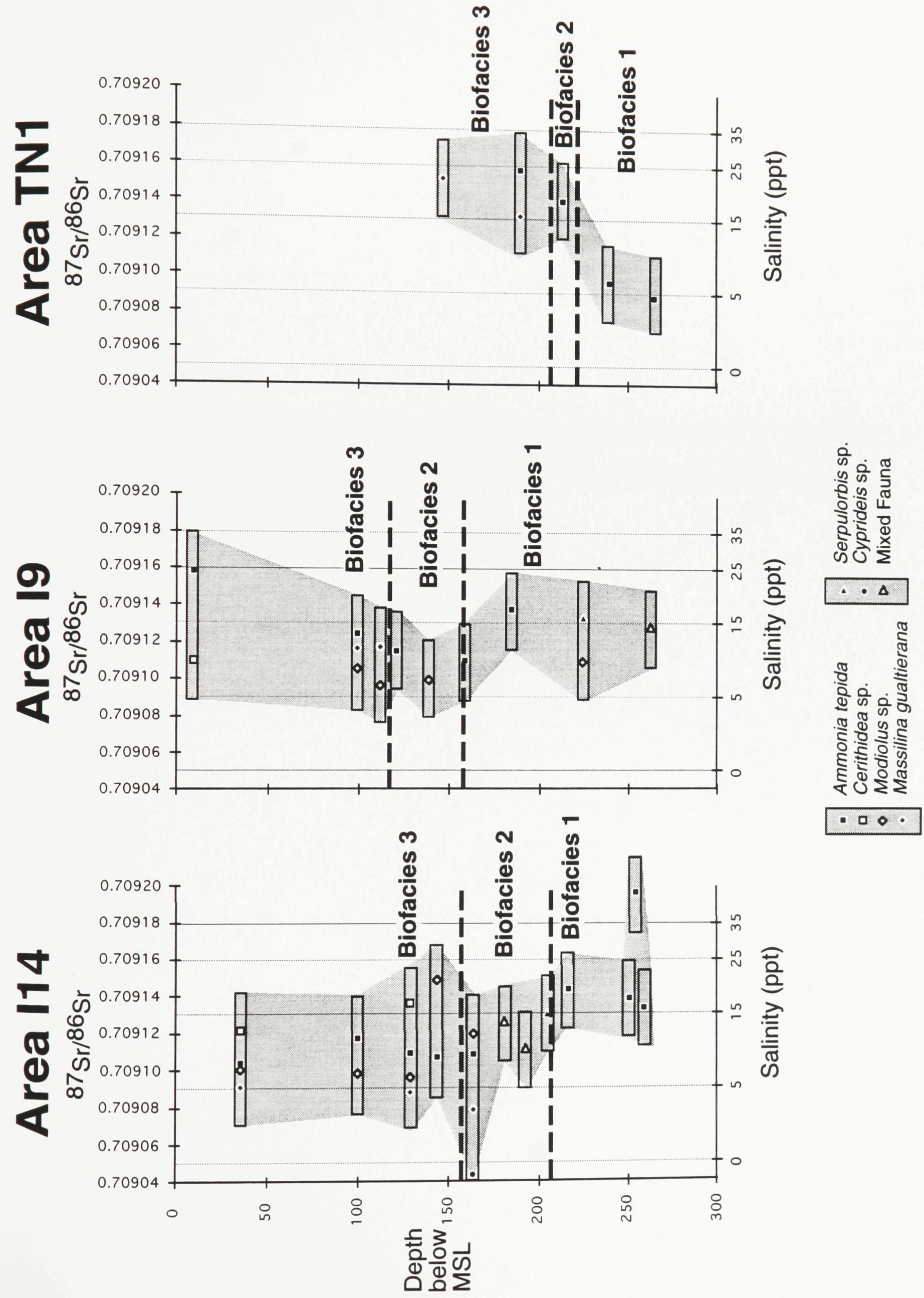
Fig. 3-6. Calculated mixing curves normalized to salinity for the sources of freshwater to the inner harbor. a) Water from the Shuni Spring; b) Travertine from the aqueduct; c) Groundwater from the inner harbor. 
a)
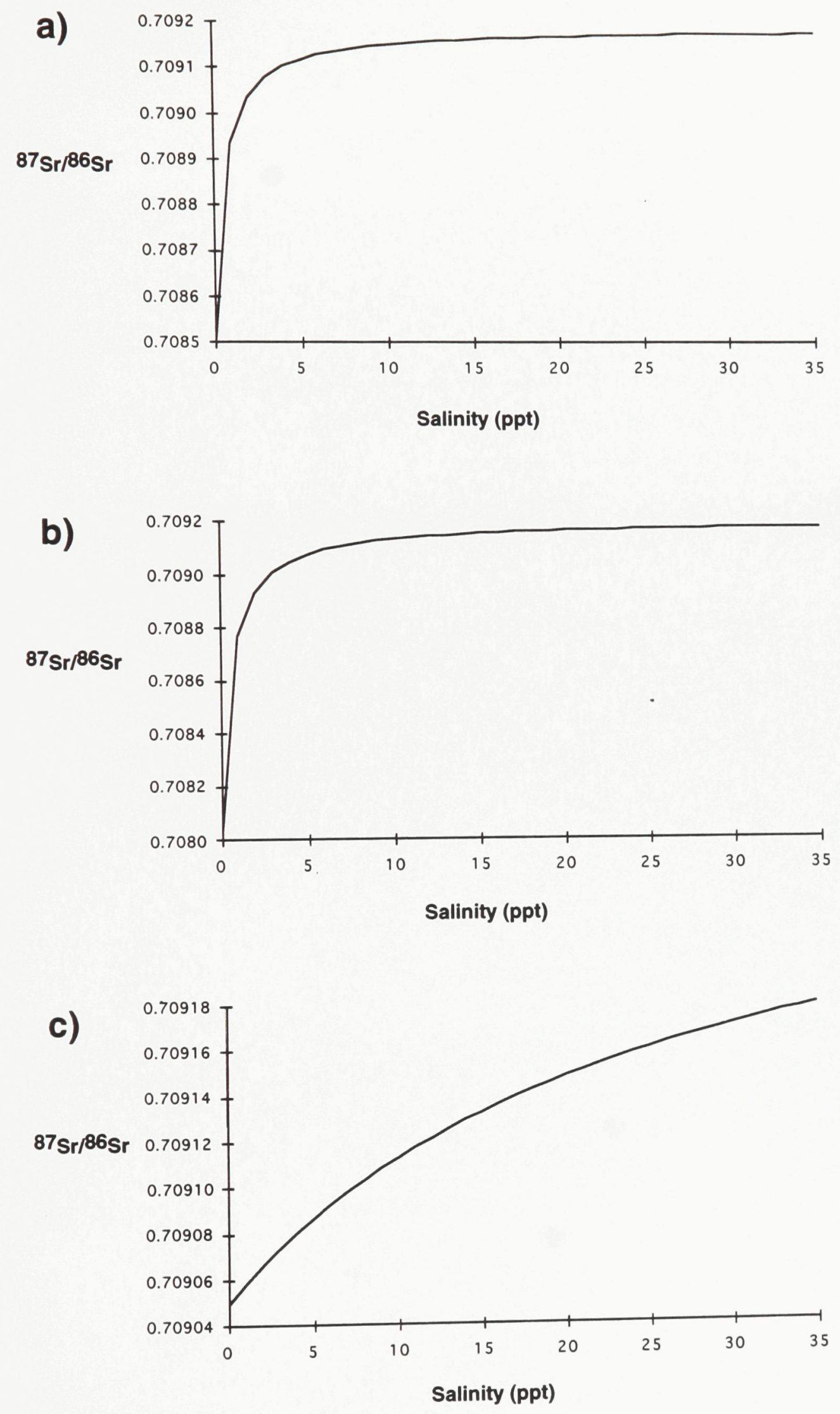
Fig. 3-7. Various stages of the inner harbor through time based on archaeological evidence which is based on Raban (1996). 


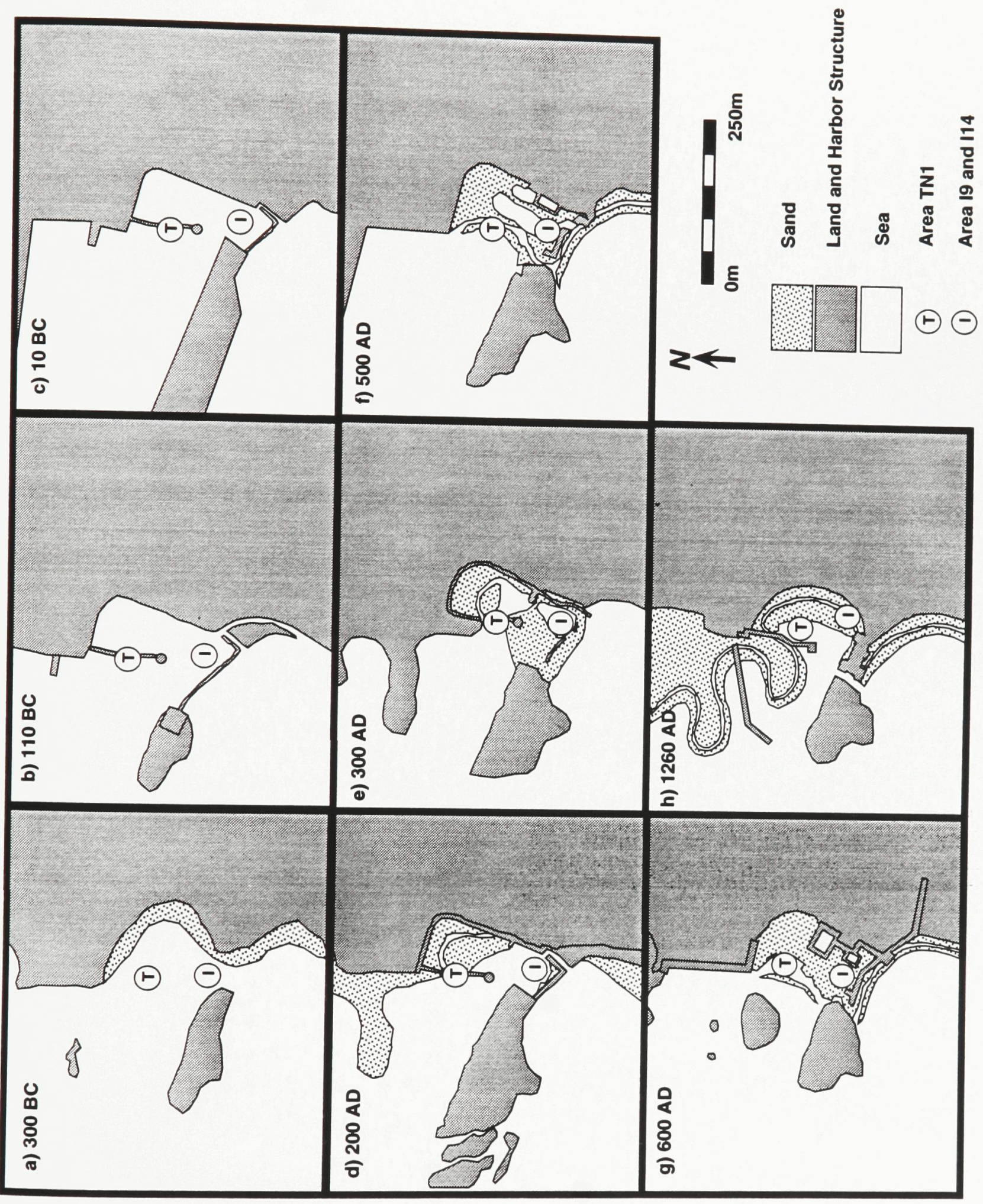


Table 3-1. Data matrix showing the fractional distributions of the statistically significant foraminiferal species in Areas TN1 and I9. The upper portion of the matrix contains the summary data as shown in Fig. 3-4. 


\begin{tabular}{|c|c|}
\hline 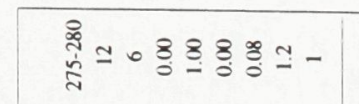 & 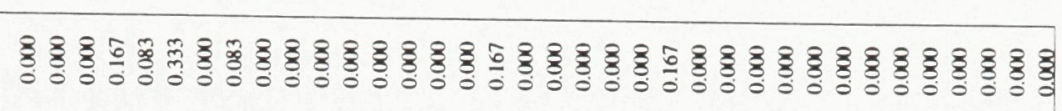 \\
\hline 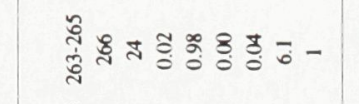 & 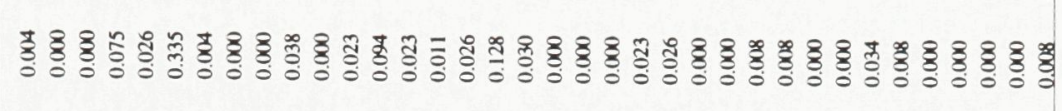 \\
\hline 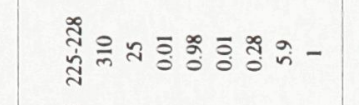 & 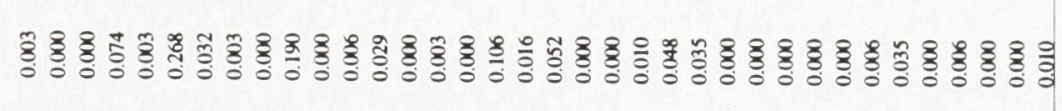 \\
\hline 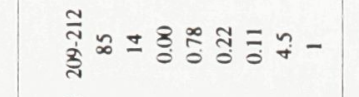 & 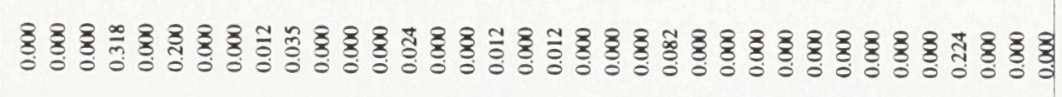 \\
\hline 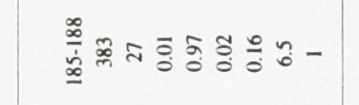 & 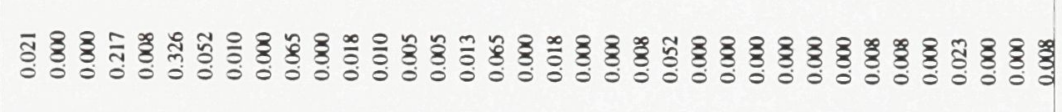 \\
\hline 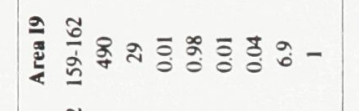 & 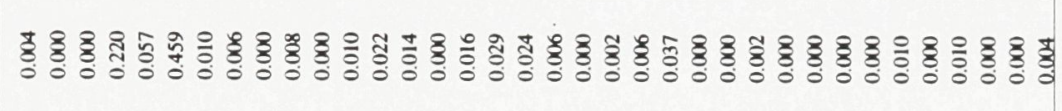 \\
\hline 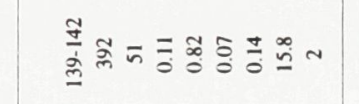 & 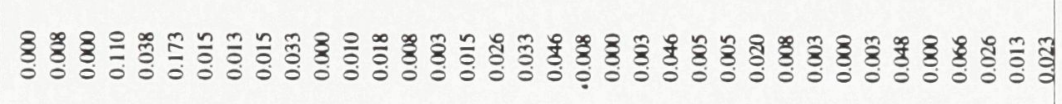 \\
\hline 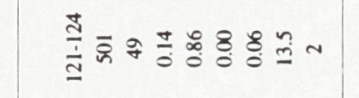 & 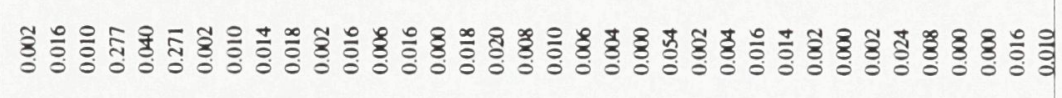 \\
\hline 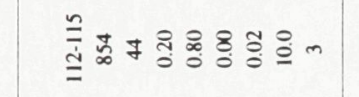 & 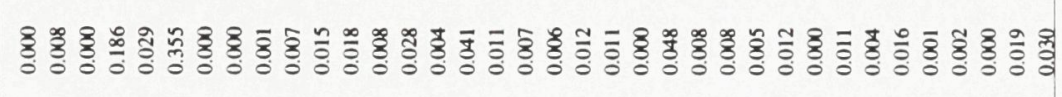 \\
\hline 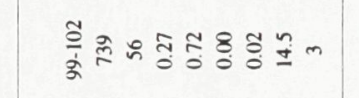 & 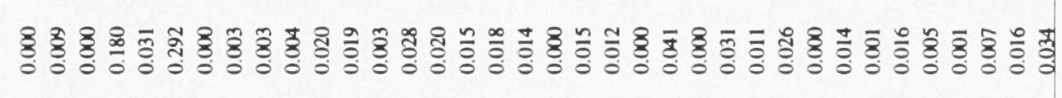 \\
\hline 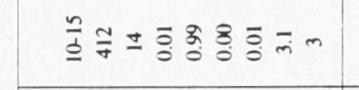 & 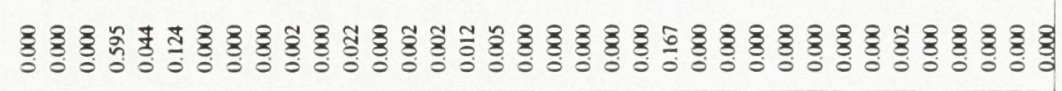 \\
\hline 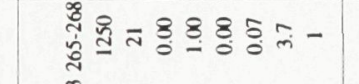 & 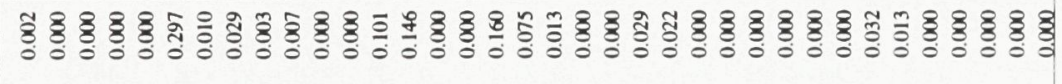 \\
\hline 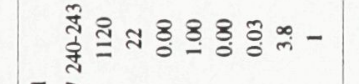 & 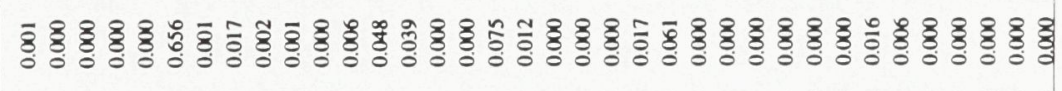 \\
\hline 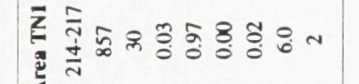 & 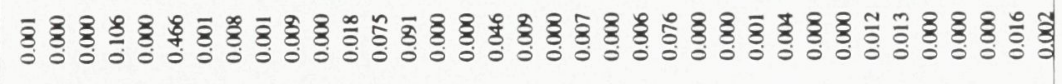 \\
\hline 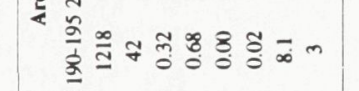 & 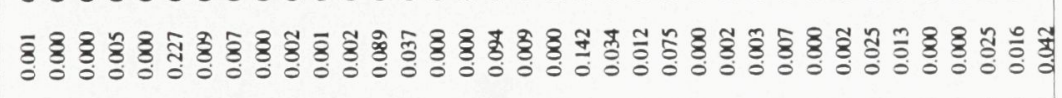 \\
\hline 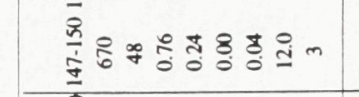 & 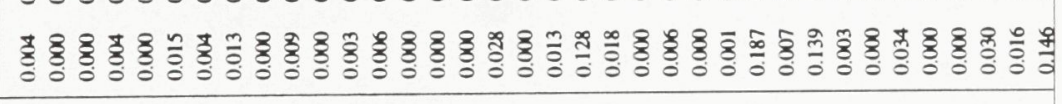 \\
\hline & \\
\hline
\end{tabular}


Table 3-2. Data matrix showing the fractional distributions of the statistically significant foraminiferal species in Areas I14. The upper portion of the matrix contains the summary data as shown in Fig. 3-4. 


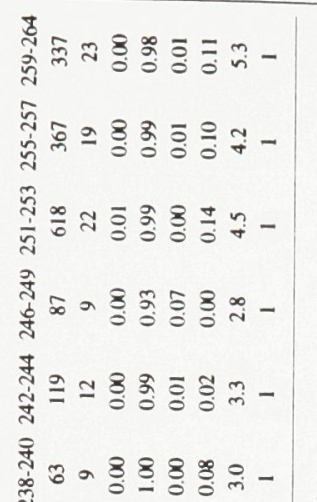

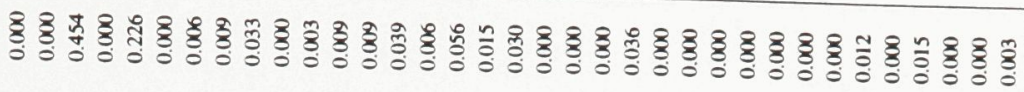

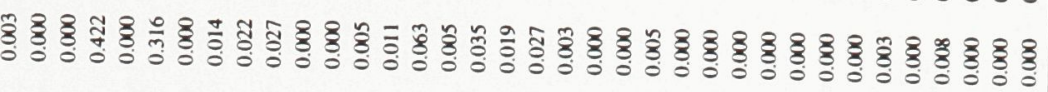

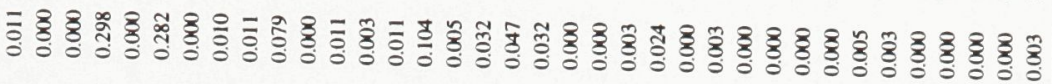

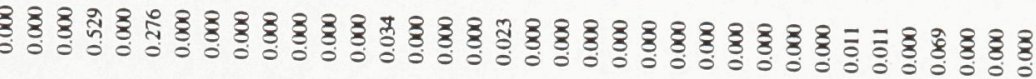

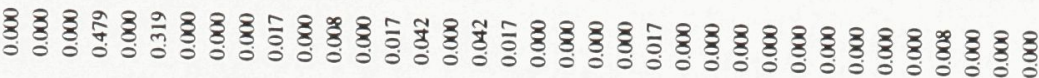

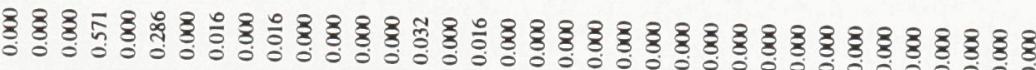

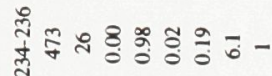

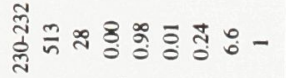
สูป

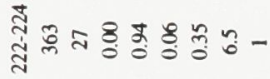

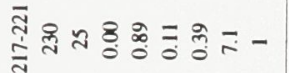

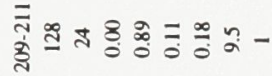

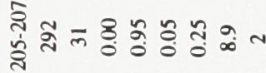

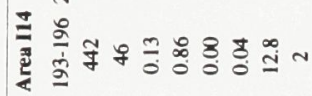

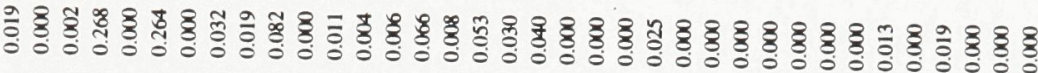

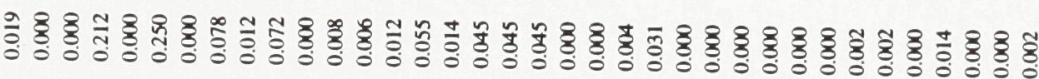

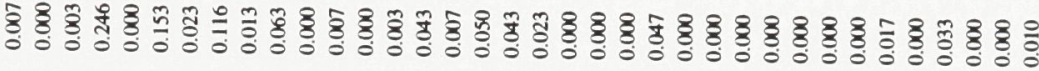

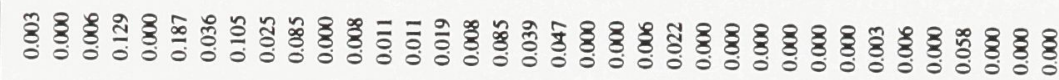
경 형 항

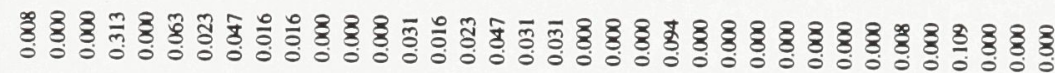

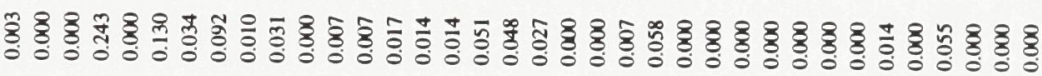

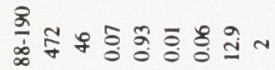

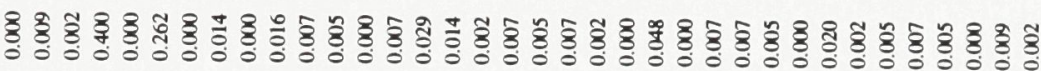

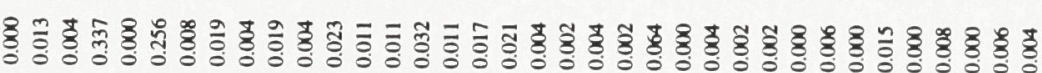

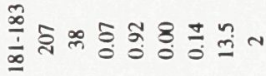

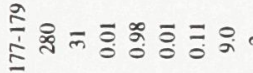

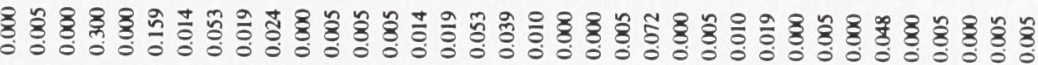

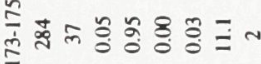

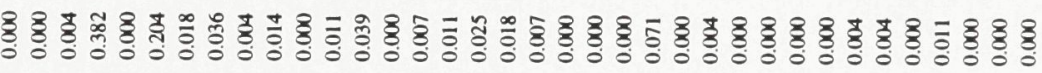

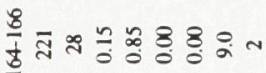

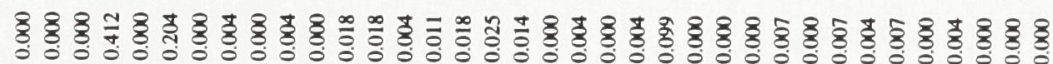

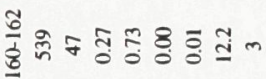

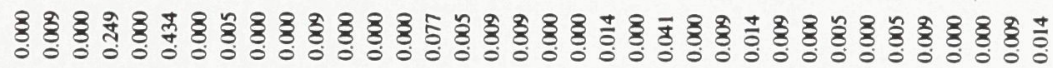

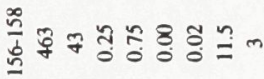

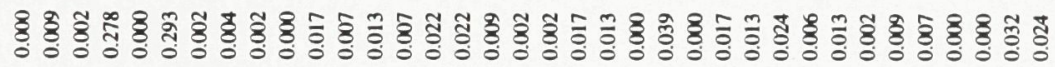

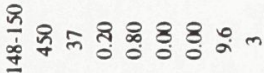

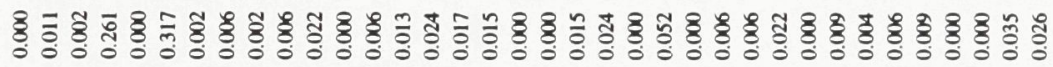

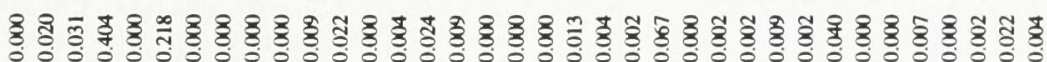

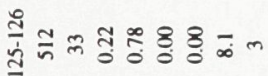

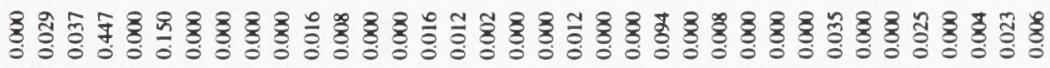

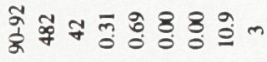

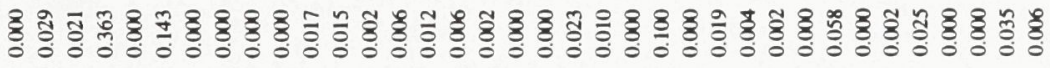

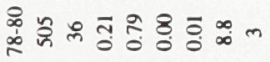

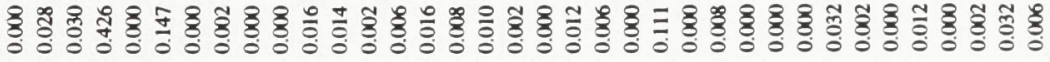

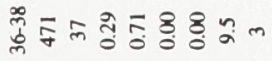

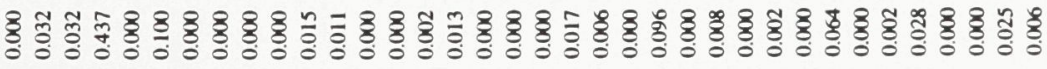


Table 3-3. Summary of the average values of each foraminiferal characteristic within the three biofacies. 


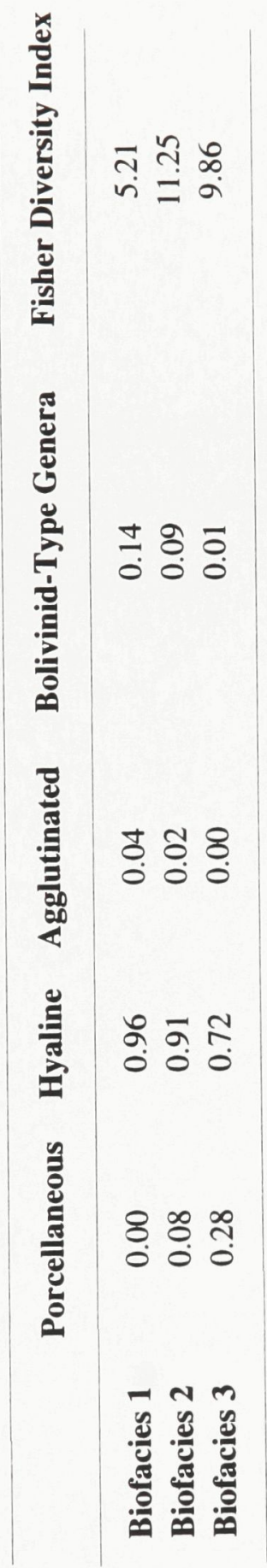


Table 3-4. ${ }^{87} \mathrm{Sr} /{ }^{86} \mathrm{Sr}$ determinations from the six different fossil taxa from the three excavation areas. The $2 \sigma$ (two standard deviations) entries are from analysis statistics which are included as a measurement of data quality. 


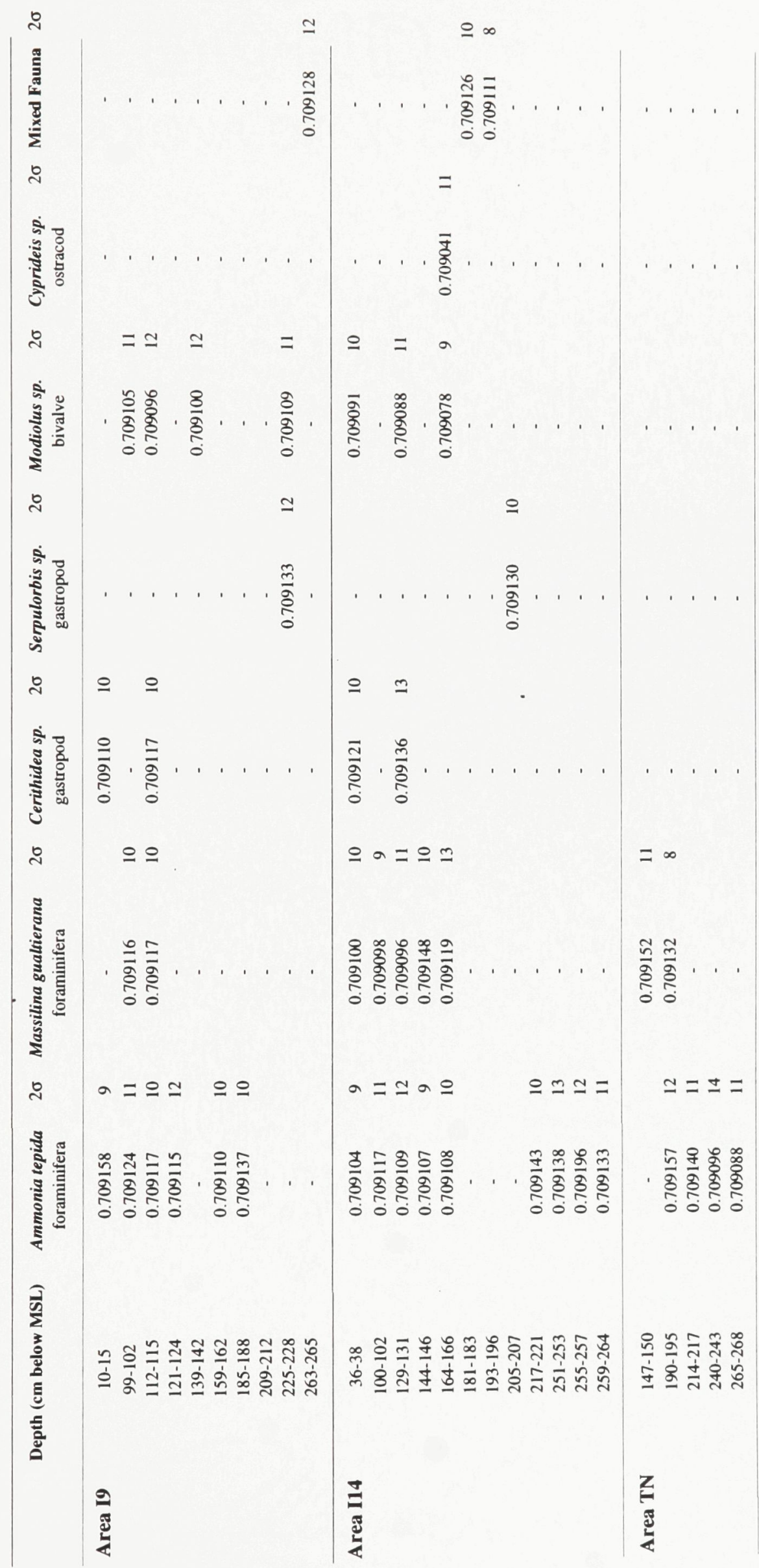


Table 3-5. ${ }^{87} \mathrm{Sr} /{ }^{86} \mathrm{Sr}$ determinations from the groundwater (C94/W1), modern seawater (C94/W2), Shuni springwater (C94/W3) and the aqueduct travertine (AQ94/1 and 2). The $2 \sigma$ (two standard deviations) entries are from analysis statistics which are included as a measurement of data quality. The strontium concentrations for the water samples are also shown, the error on these measurements is approximately $\pm 1.5 \%$. 


\begin{tabular}{cccc} 
Sample & $\mathbf{8 7 S r} / \mathbf{8 6 S r}$ & $2 \sigma$ & $\mathbf{S r}$ (ppm) \\
\hline AQ94/1 & 0.708066 & 11 & - \\
AQ94/2 & 0.708029 & 15 & - \\
C94/W1 & 0.709053 & 6 & 3.37 \\
C94/W2 & 0.709148 & 9 & 6.03 \\
C94/W3 & 0.708511 & 14 & 0.134
\end{tabular}


Plate 3-1. 1. Rectuvigerina royoi Bermúdez and Fuenmayer, 1963 x140. 2.Bolivina pseudoplicata Heron-Allen and Earland, 1930 x100. 3. Bolivina variabilis (Williamson, 1858). 4. Brizalina striatula (Cushman, 1922) x210. 5. Elphidium gerthi Van Voorthuysen, 1957 x100. 6. Elphidium translucens Nat1and, 1938 x100. 7. Porosononion granosum (d'Orbigny, 1846) x160. 8. Tretomphalus bulloides (d'Orbigny, 1839) x117. 9. Haynesina depressula (Walker and Jacob, 1798) x171. 10. Elphidium margaritaceum (Cushman, 1930) x100. 11. Ammonia tepida (Cushman, 1936) x245. 12. Ammonia parkinsoniana (d'Orbigny, 1839) x75. 13. Ammonia inflata (Sequenza, 1862) x115. 

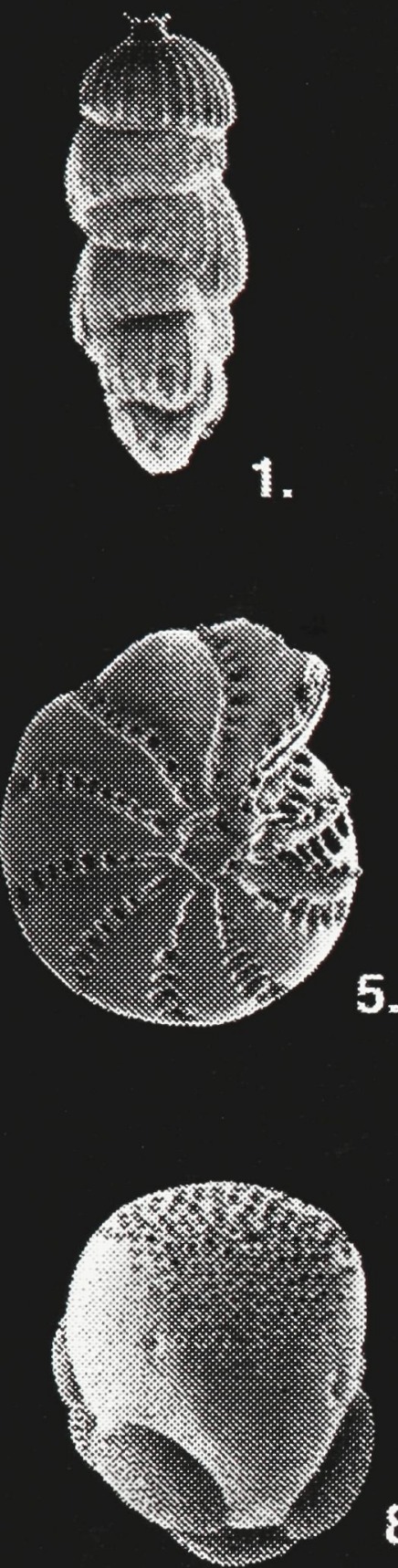

8.

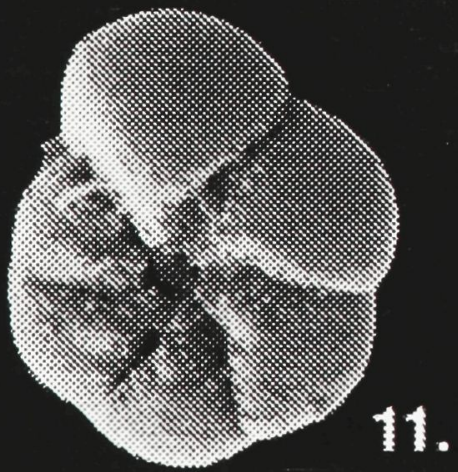

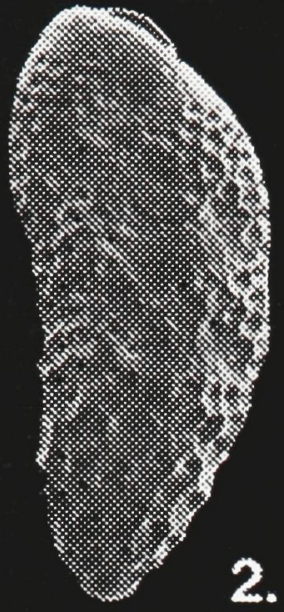

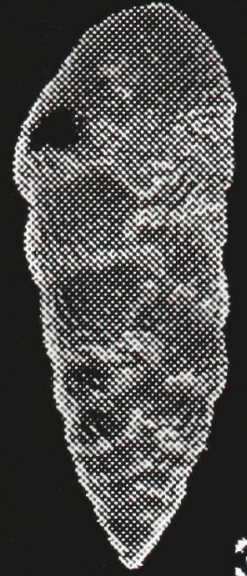

3.
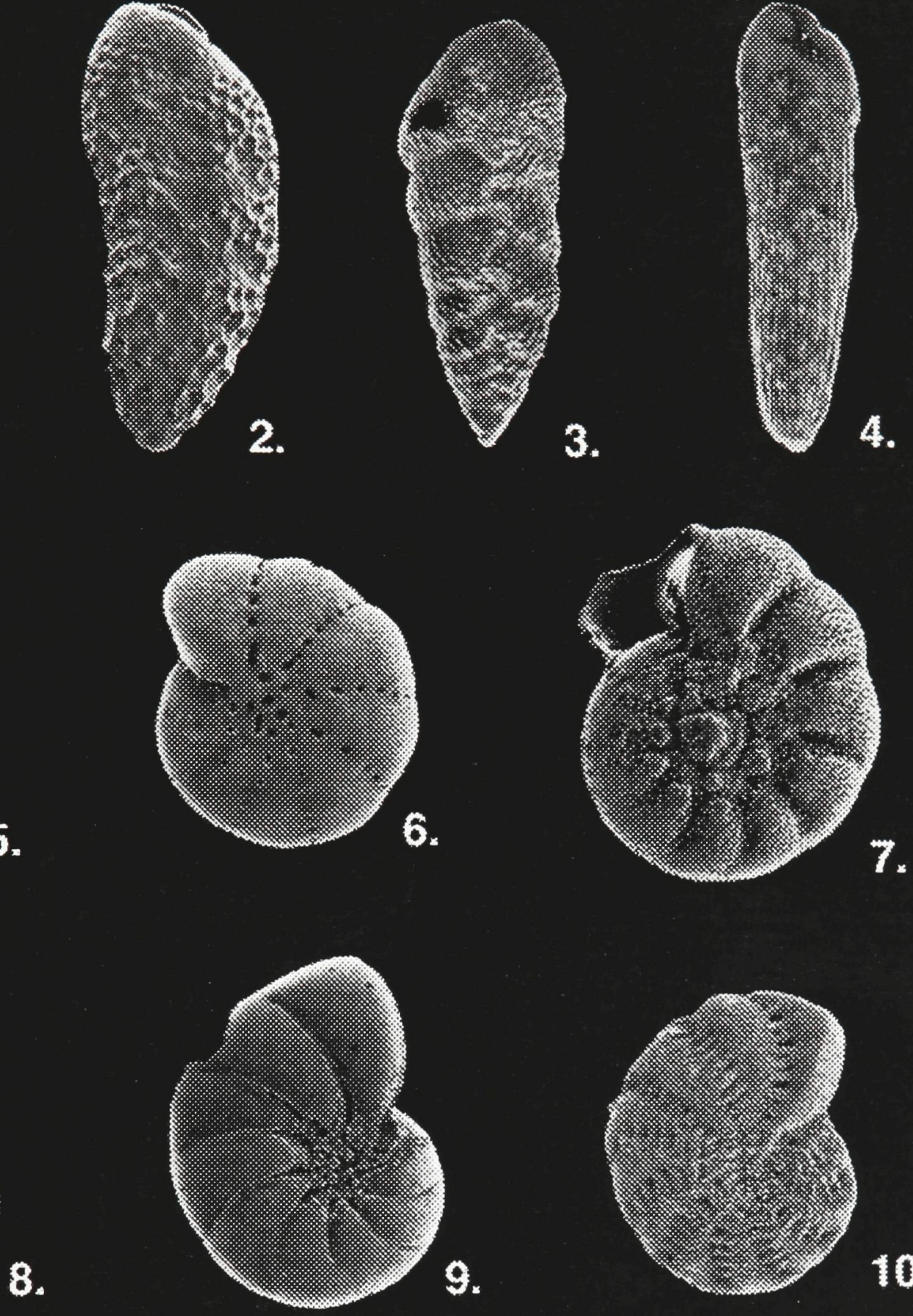

10.

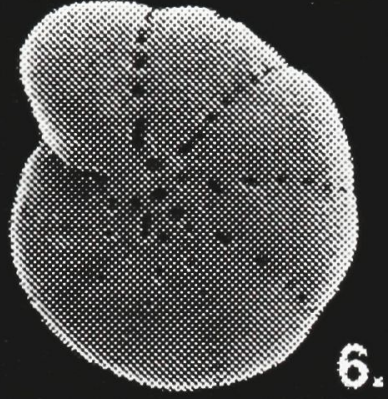

7.
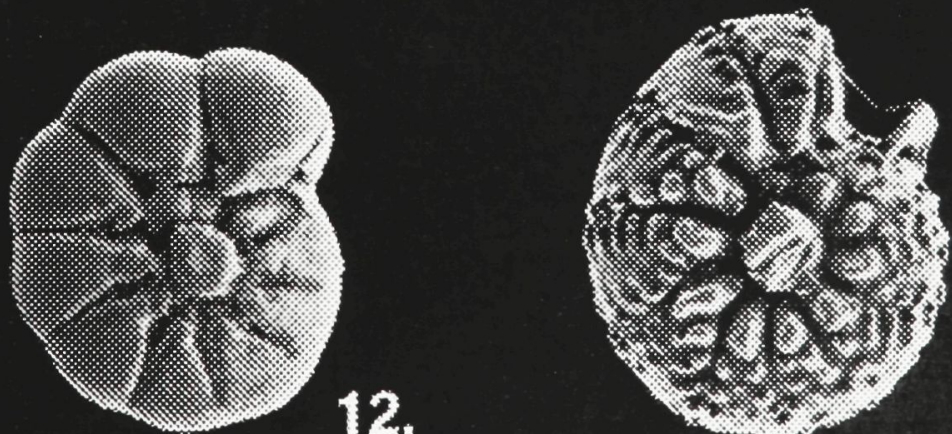

12. 
Plate 3-2. 14. Quinqueloculina patagonica d'Orbigny, $1839 \times 203$. 15. Sorites orbiculus Ehrenberg, 1839 x100. 16. Miliolinella subrotunda (Montagu, 1803). 17. Pseudotriloculina rotunda (d'Orbigny, 1826) x138. 18. Triloculina subgranulata Cushman, 1918 x120. 19. Massilina gualtierana (d'Orbigny, 1839) x190. 

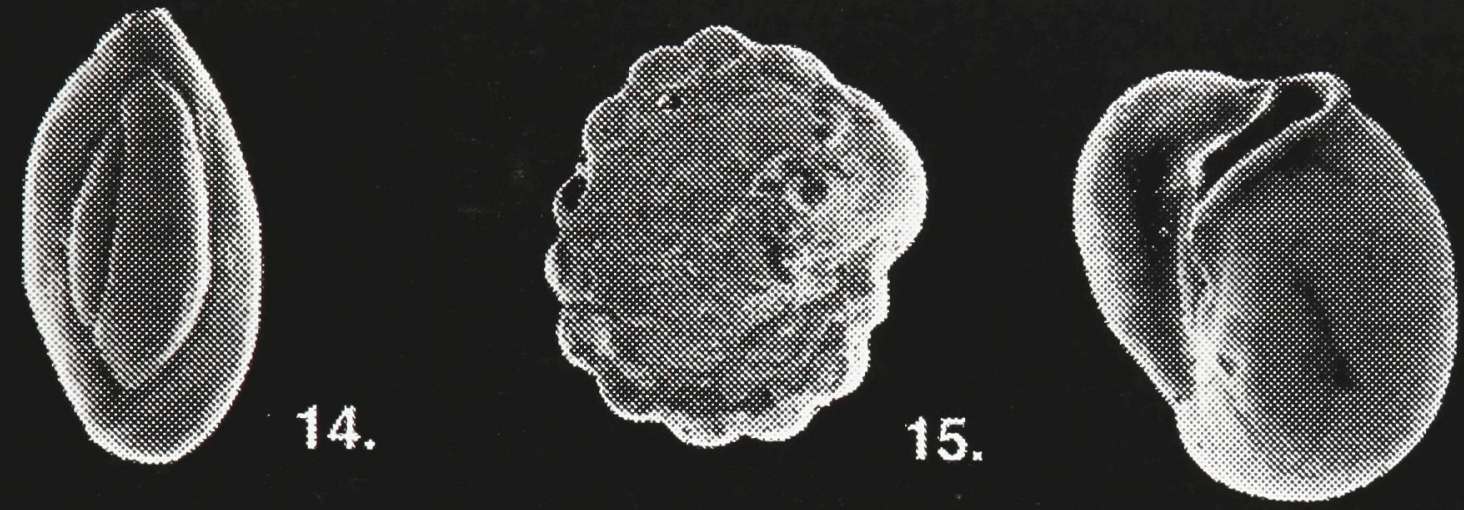

16.
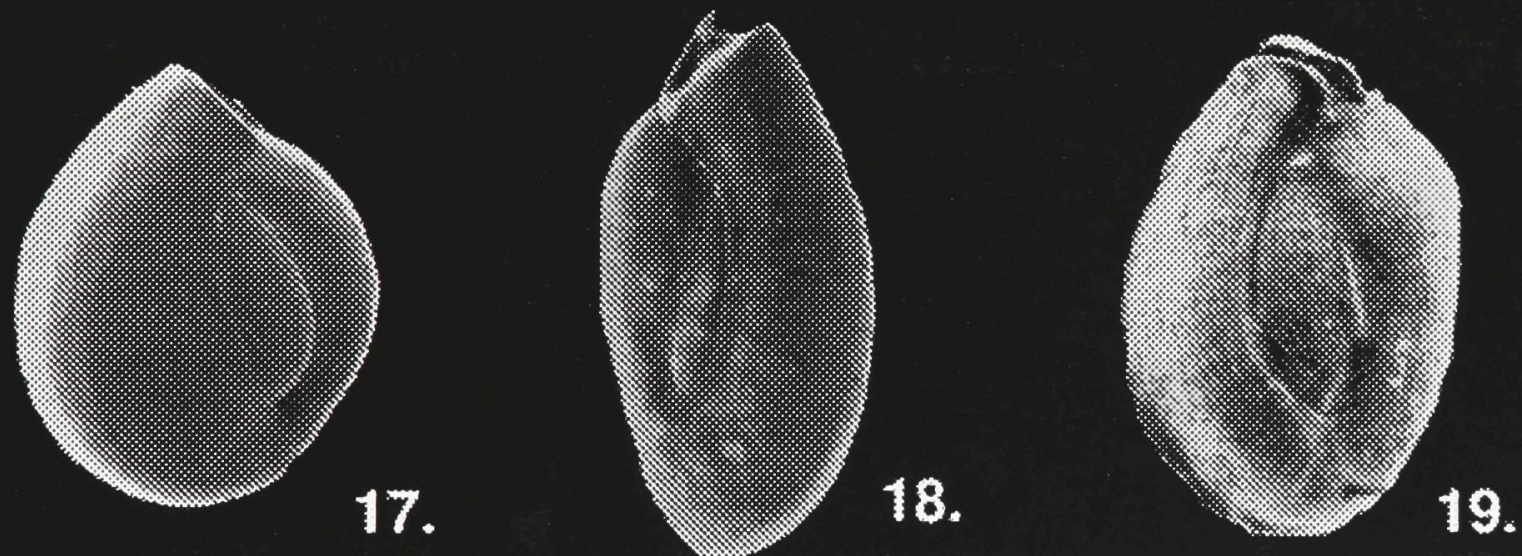
Appendix 3-1. Species are listed alphabetically. As the nature of this paper was not taxonomic, full species synonymies are not provided. Where the original generic designation varied with the present usage, the original was provided. 


\section{FAUNAL LIST}

Abditodentrix rhomboidalis = Textularia rhomboidalis Millett, 1899

Adelosina carinata-striata = Adelosina milletti var. carinata-striata Wiesner, 1923

Adelosina dubia = Triloculina dubia d'Orbigny, 1826

Adelosina mediterranensis Le Calvez, J. and Y., 1958

Adelosina sp 1

Adelosina sp 2

Adelosina sp 3

Affinetrina planciana $=$ Triloculina planciana d'Orbigny, 1839

Ammonia inflata $=$ Rosalina inflata Sequenza, 1862

Ammonia parkinsoniana $=$ Rosalina parkinsoniana d'Orbigny, 1839

Ammonia sp 1

Ammonia tepida $=$ Rotalia beccarii var. tepida Cushman, 1936

Articulina carinata Wiesner, 1923

Asterigerinata mamilla $=$ Rotalina mamilla Williamson, 1858

Aubignyna planidorso = Buccella planidorsa Atkinson, 1969

Bolivina pseudoplicata Heron-Allen and Earland, 1930

Bolivina variabilis $=$ Textularia variabilis Williamson, 1858

Bolivinellina sp 1

Brizalina difformis $=$ Textularia variabilis var. difformis Williamson, 1858

Brizalina dilatata $=$ Bolivina dilatata Reuss, 1850

Brizalina striatula $=$ Bolivina striatula Cushman, 1922

Bulimina elongata d'Orbigny, 1846

Bulimina marginata d'Orbigny, 1846

Cassidella $\mathrm{sp} 1$

Cibicidella variabilis d'Orbigny, 1846 
Cibicides pseudolobatulus Perelis and Reiss, 1975

Cibicides sp 1

Conorbella patelliformis = Discorbina patelliformis Brady, 1884

Cornuspira foliacea $=$ Orbis foliaceus Philippi, 1844

Cycloforina sp 1

Cymbaloporetta sp 1

Elphidium advenum = Polystomella advena Cushman, 1922

Elphidium gerthi Van Voorthuysen, 1957

Elphidium jenseni Cushman, 1905

Elphidium limbatum $=$ c.f. Polystomella macella Fichtel and Moll var. limbata Chapman, 1909

Elphidium margaritaceum $=$ Elphidium advenum var. margaritaceum Cushman, 1930

Elphidium sp 1

Elphidium translucens Natland, 1938

Eponides repandus $=$ Nautilus repandus Fichtel and Moll, 1798

Floresina sp 1

Fursenkoina acuta $=$ Polymorphina acuta d'Orbigny, 1846

Globofissurella sp 1

Gyroidinoides lamarckiana $=$ Rotalia lamarckiana d'Orbigny, 1839

Haynesina depressula $=$ Nautilus depressulus Walker and Jacob, 1798

Haynesina sp 1

Haynesina sp 2

Hopkinsinella sp 1

Lenticulina sp 1

Lobatula lobatula $=$ Nautilus lobatulus Walker and Jacob, 1798

Loxostomina sp 1

Massilina gualtierana = Quinqueloculina gualtierana d'Orbigny, 1839 
Miliolinella semicostata $=$ Miliolina semicostata Wiesner, 1923

Miliolinella sp 1

Miliolinella subrotunda $=$ Vermiculum subrotundum Montagu, 1803

Nonion commune

Nonionella opima Cushman, 1947

Pararotalia spinigera $=$ Globorotalia spinigera Le Calvez, 1949

Parrina bradyi $=$ Nubecularia bradyi Millett, 1898

Peneroplis pertusus $=$ Nautilus pertusus Foskål, 1775

Porosononion granosum = Noionina granosa d'Orbigny, 1846

Porosononion sp 1

Pseudotriloculina laevigata $=$ Triloculina laevigata d'Orbigny, 1826

Pseudotriloculina rotund $a=$ Triloculina rotunda d'Orbigny, 1826

Pseudotriloculina sp 1

Pyrgoella sphaera $=$ Biloculina sphaera d'Orbigny, 1839

Quinqueloculina auberiana d'Orbigny, 1839

Quinqueloculina laevigata d'Orbigny, 1839

Quinqueloculina parvula Schlumberger, 1894

Quinqueloculina patagonica d'Orbigny, 1839

Quinqueloculina sp 1

Quinqueloculina sp 2

Quinqueloculina sp 3

Quinqueloculina sp 4

Quinqueloculina sp 5

Quinqueloculina sp 6

Quinqueloculina sp 7

Quinqueloculina ungeriana d'Orbigny, 1846

Rectuvigerina royoi Bermúdez and Fuenmayer, 1963 
Reussella spinulosa = Verneuilina spinulosa Reuss, 1850

Rosalina floridensis = Rosalina bertheloti (d'Orbigny) var. floridensis Cushman, 1931

Rosalina sp 1

Rosalina vilardeboana d'Orbigny, 1839

Sigmoilinita costata $=$ Sigmoilina costata Schlumberger, 1893

Siphonaperta agglutinans = Quinqueloculina agglutinans, d'Orbigny, 1839

Siphouvigerina sp 1

Sorites orbiculus Ehrenberg, 1839

Textularia bocki Höglund, 1947

Tretomphalus bulloides $=$ Rosalina bulloides d'Orbigny, 1839

Triloculina adriatica Le Calvez, J. and Y., 1958

Triloculina marioni Schlumberger, 1893

Triloculina plicata Terquem, 1878

Triloculina sp1

Triloculina subgranulata Cushman, 1918

Uvigerina mediterranea, Hofker, 1932

Virgulopsis italica $=$ Bolivina italica Cushman, 1949 
Appendix 3-2. Foraminiferal fractional abundances in Areas TN1, I9 and I14 with associated $95 \%$ confidence interval. 


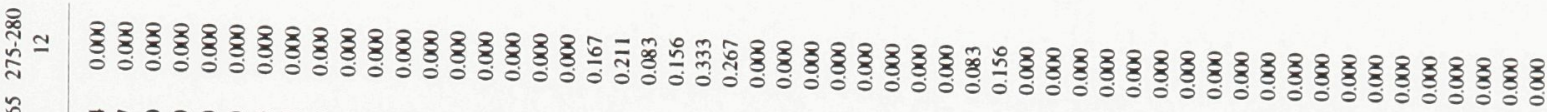

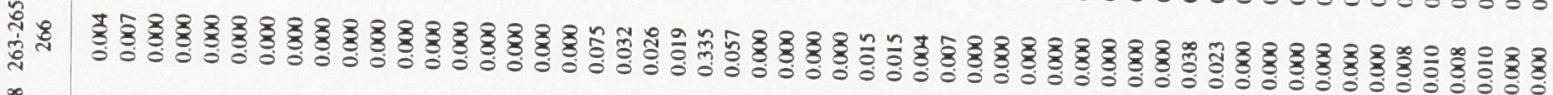

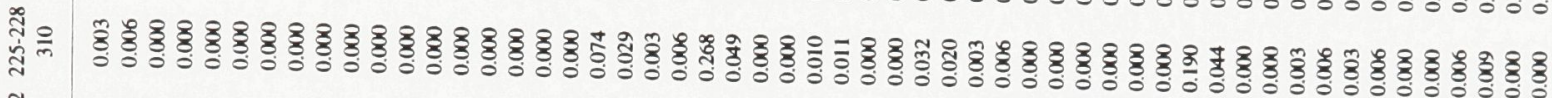
곷

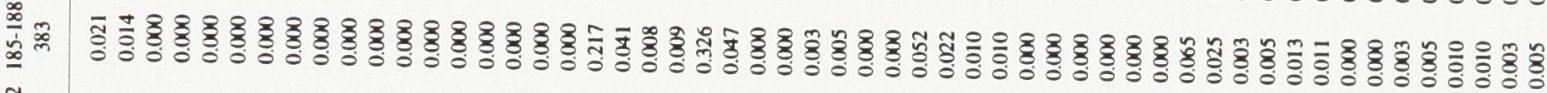

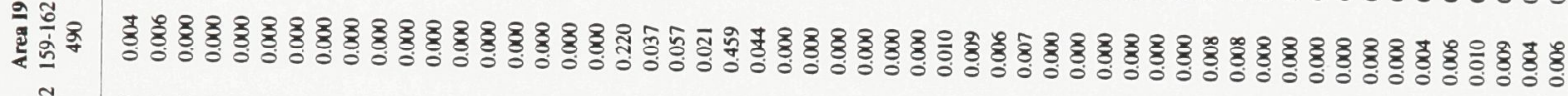

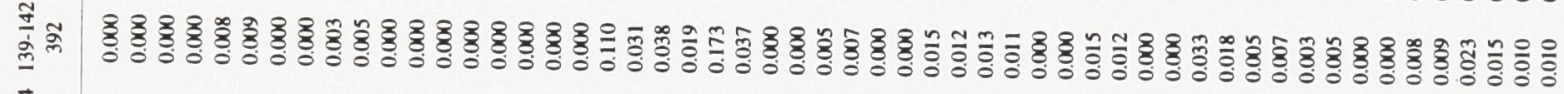

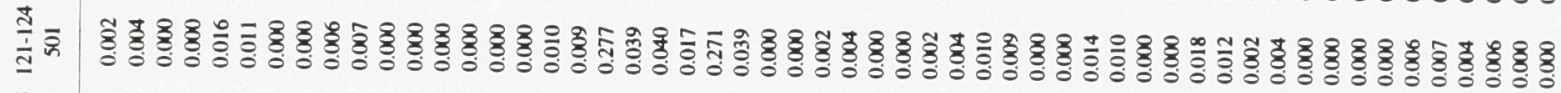

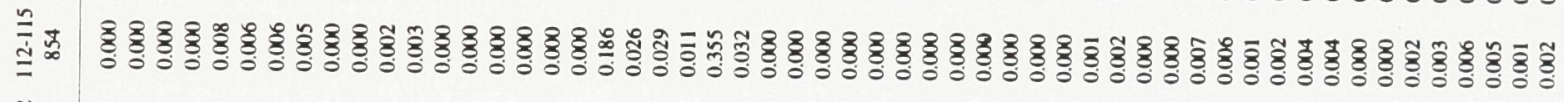

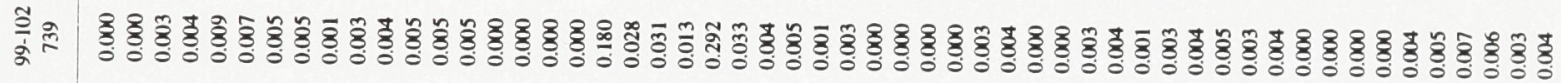

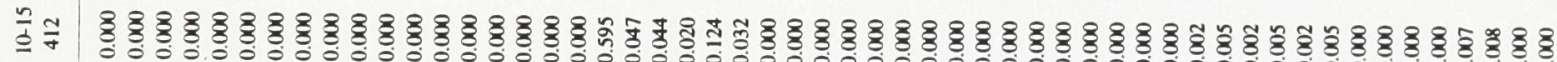

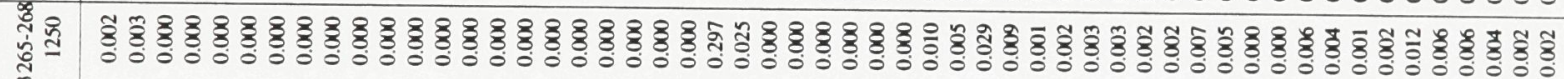

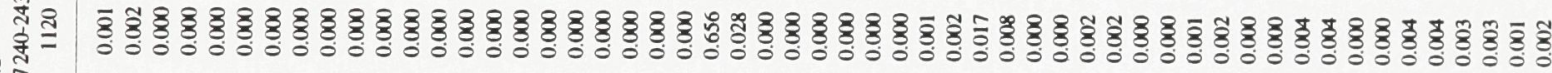

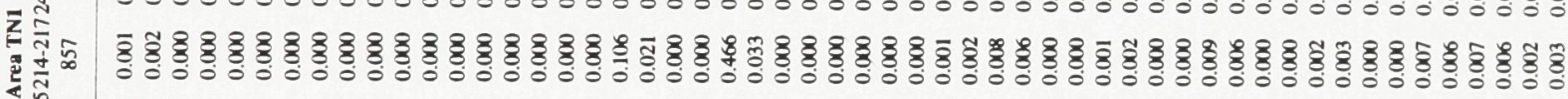

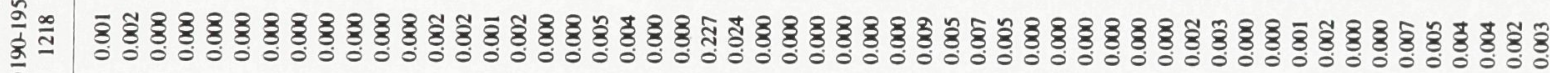

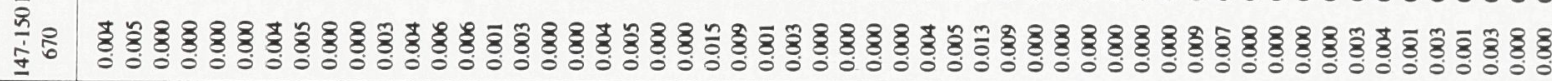

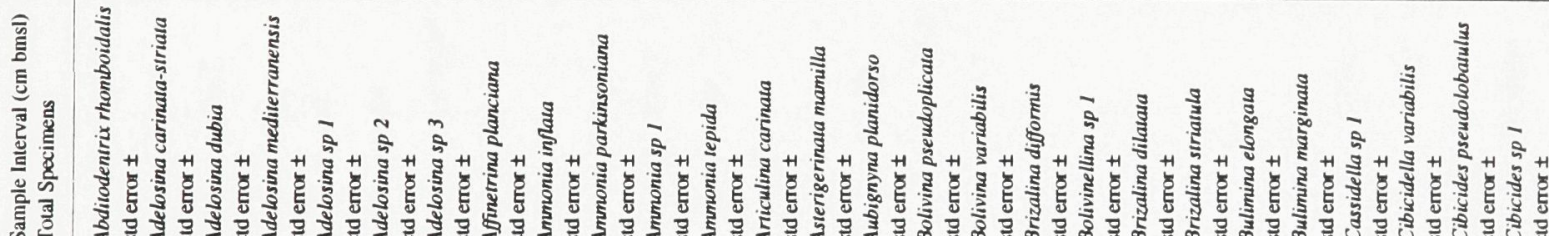




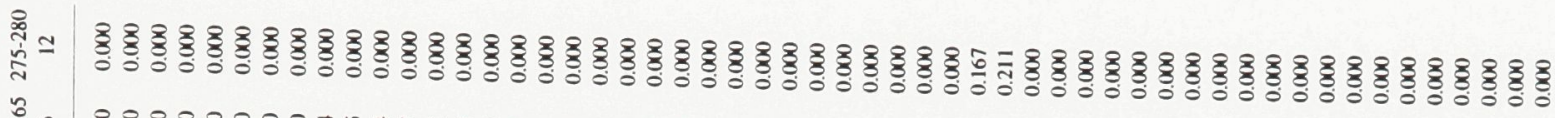

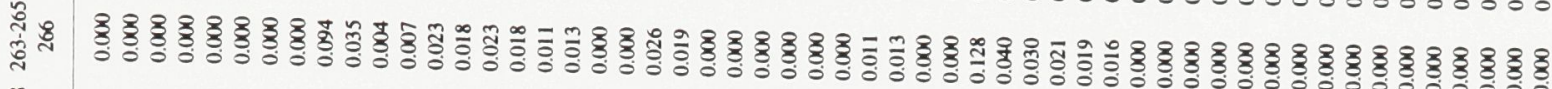

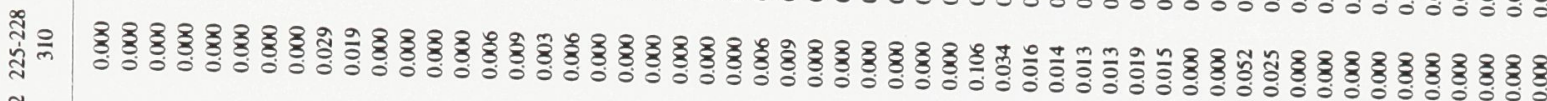

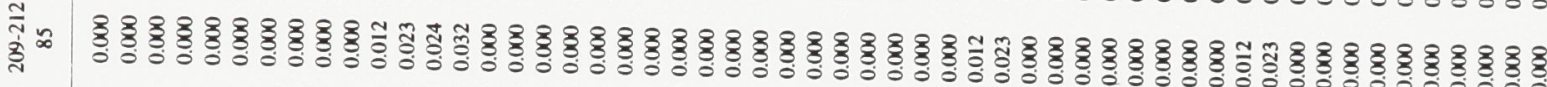

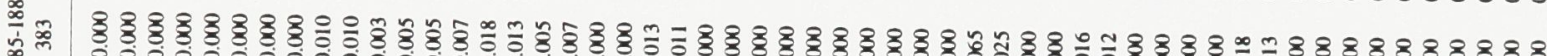
约

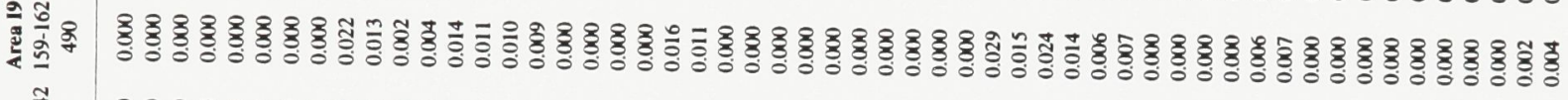

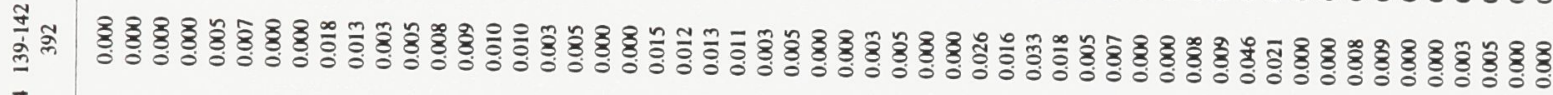
ํํำำ ํㅗำ

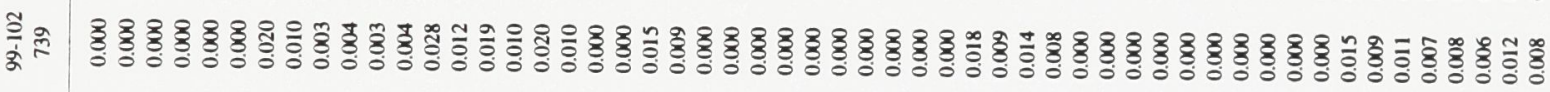

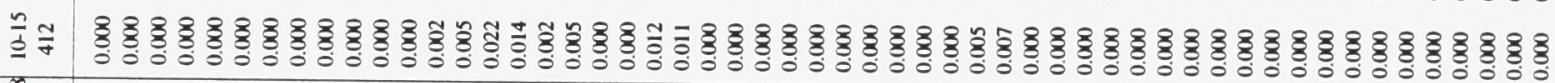

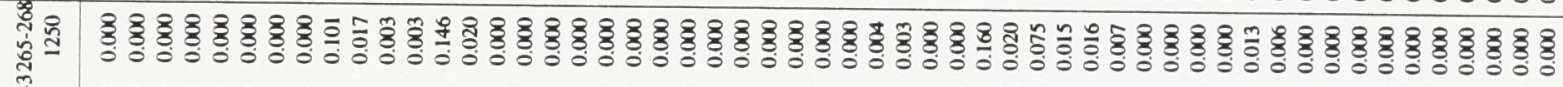

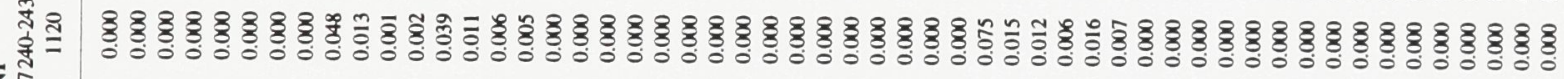

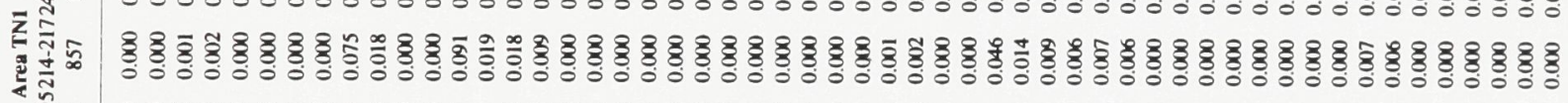

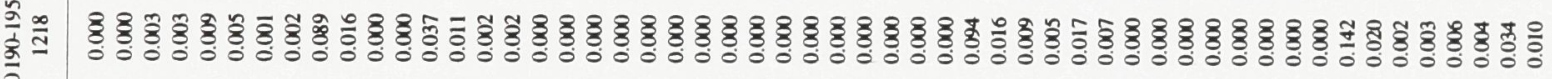

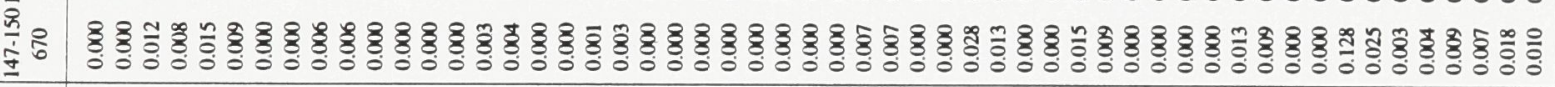

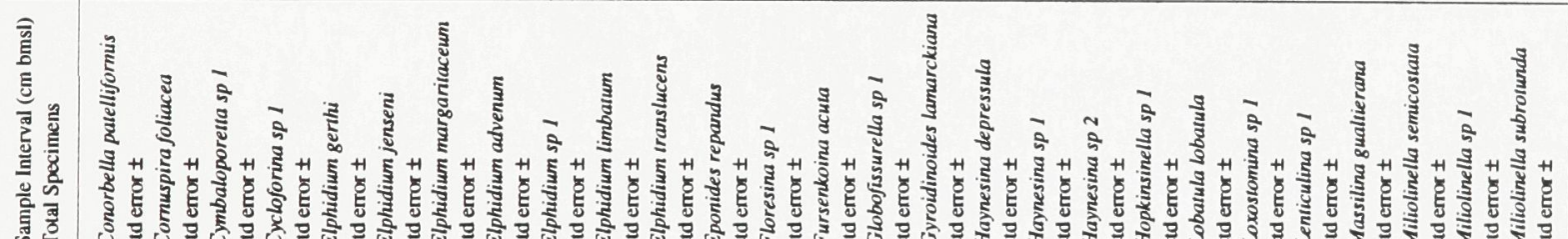




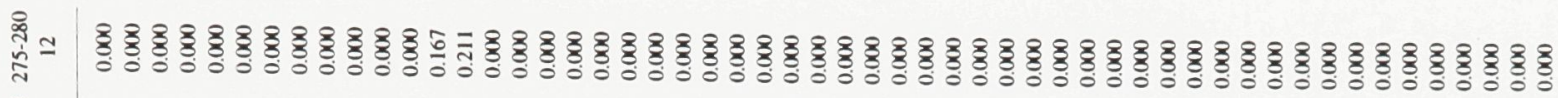

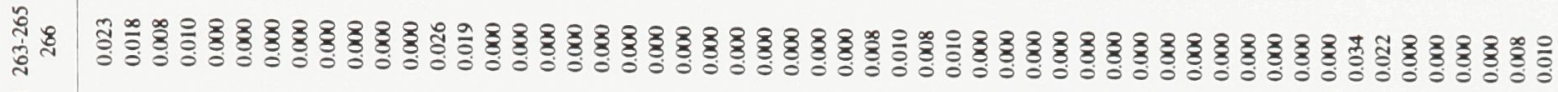

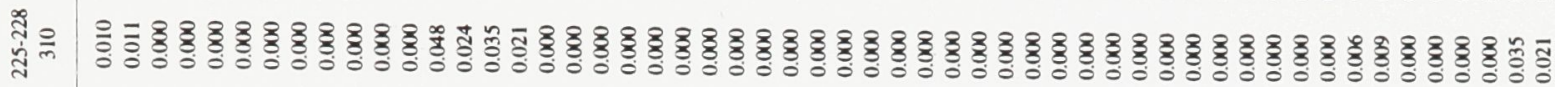

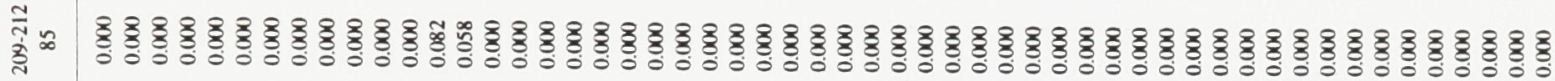

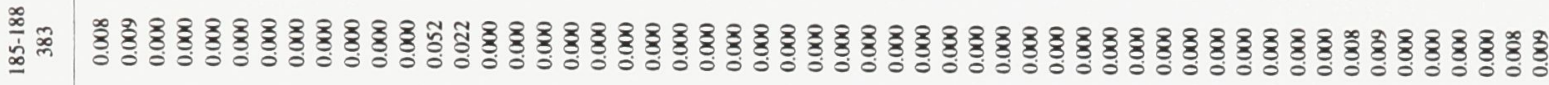

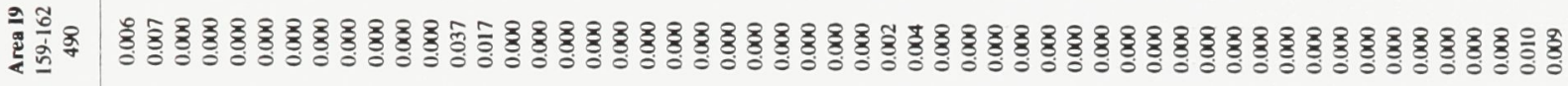
ํㅗㄹㅗำ ํํำ

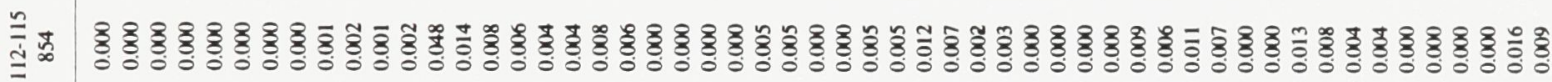

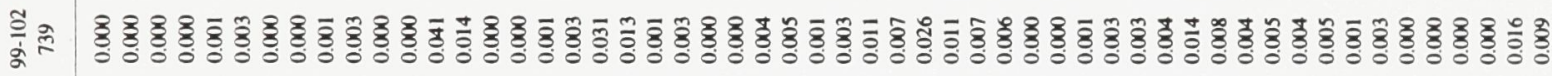

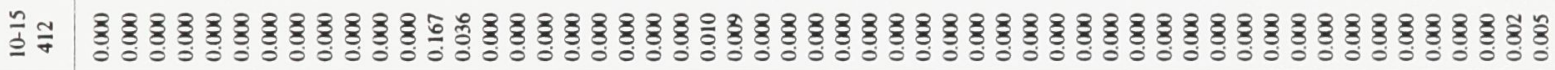

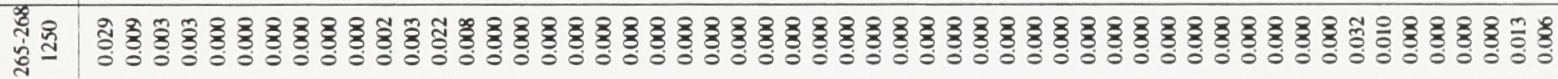

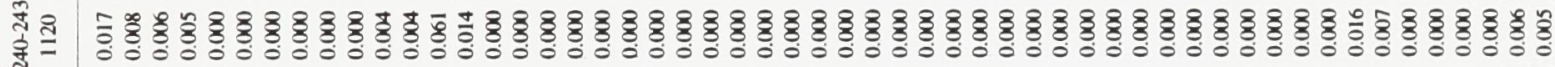

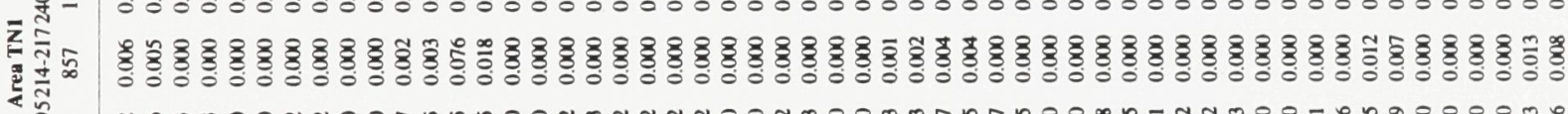

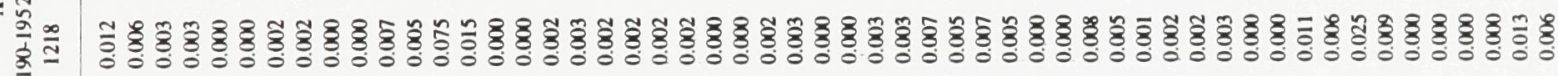

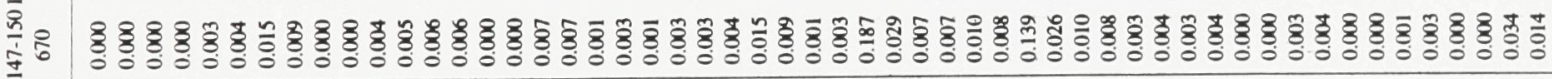

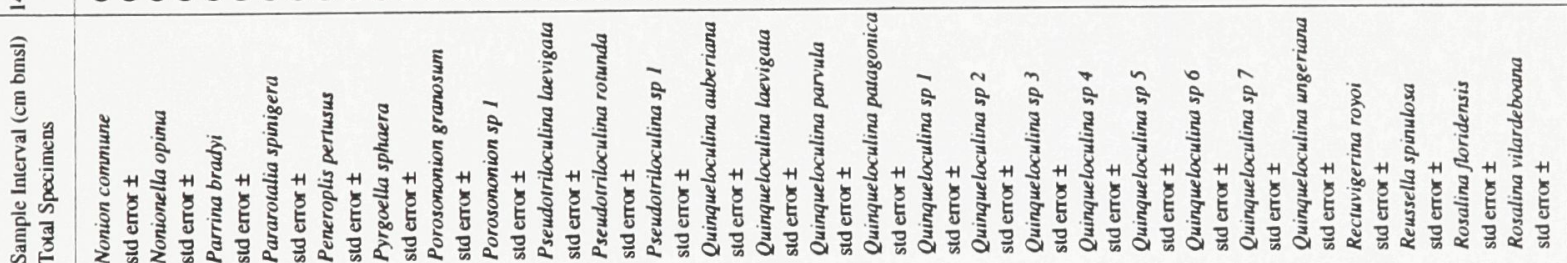




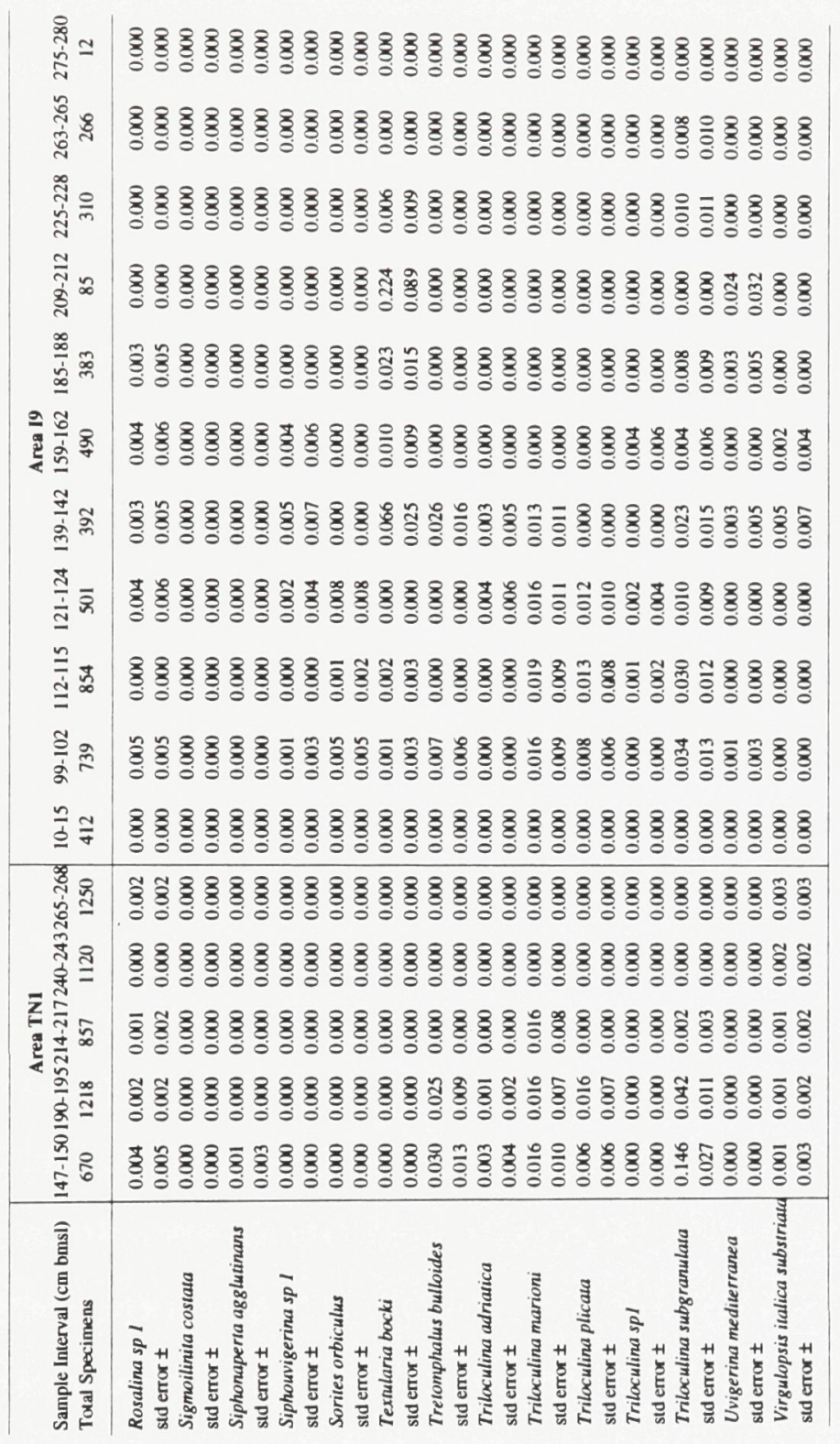


䒺

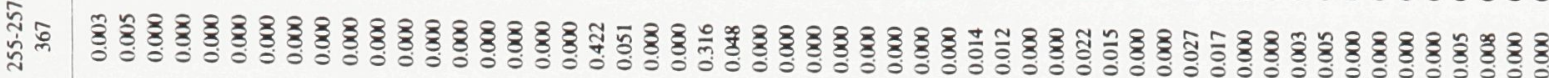

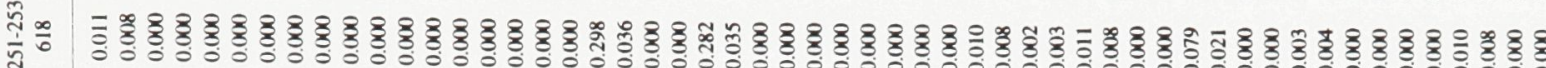

疍

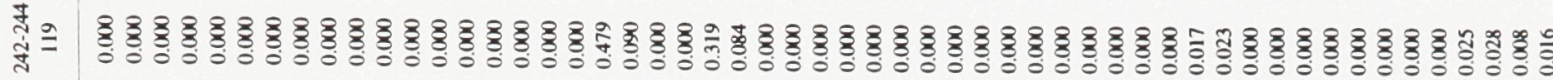

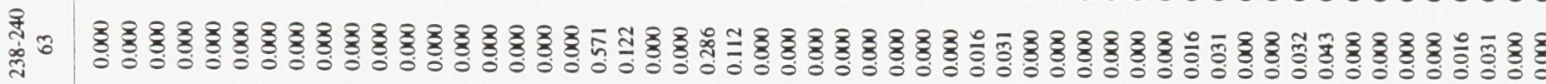

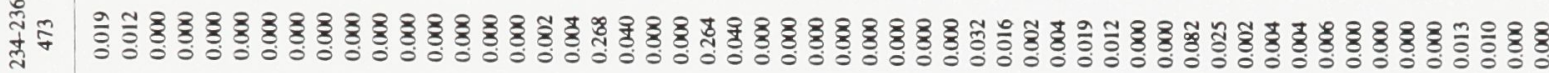

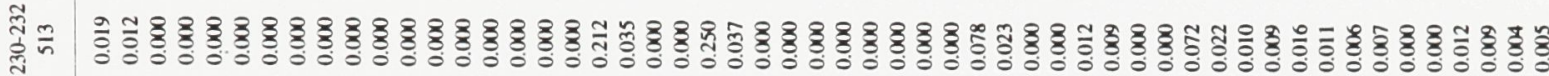

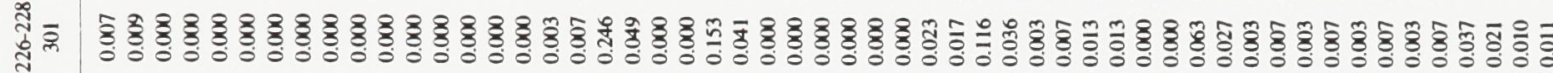

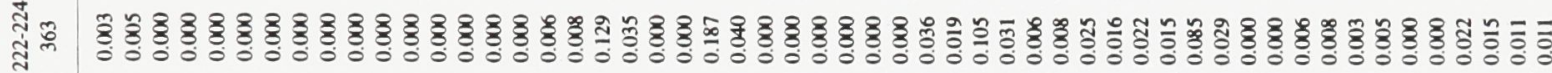

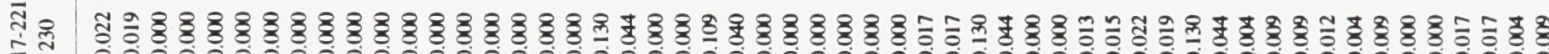

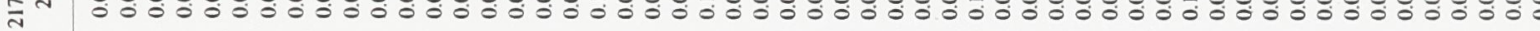

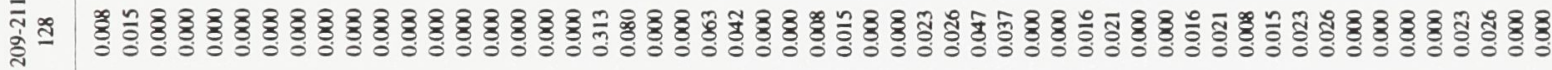

๙

4.

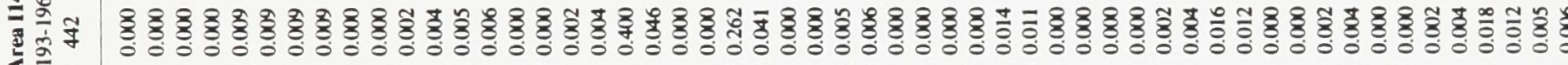

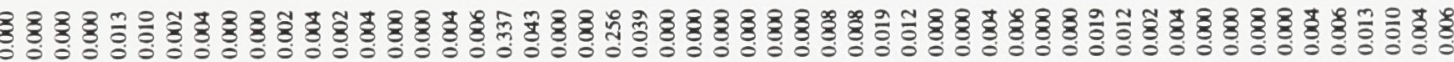

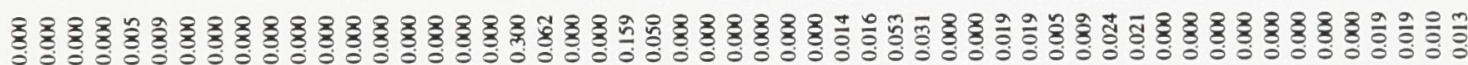

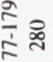

辛票 $\frac{8}{8}$ 줄

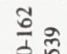

$\frac{8}{2}$

竞要

高离哥

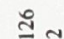

过

羿孪

要学

䑻字

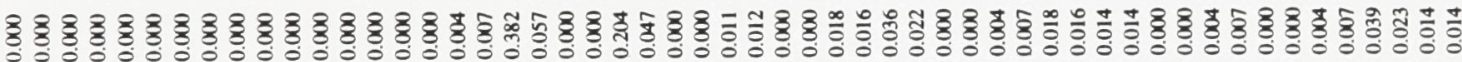

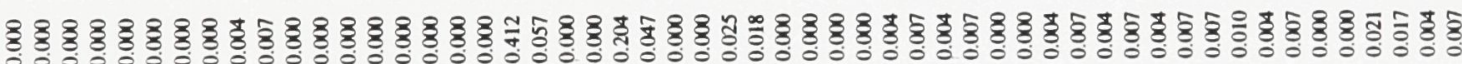

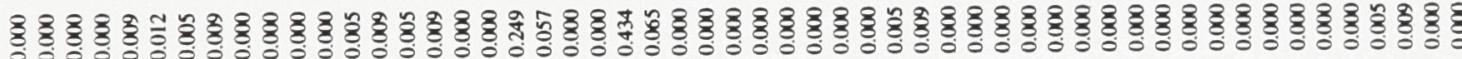

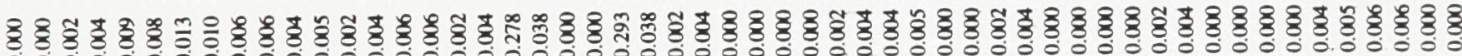

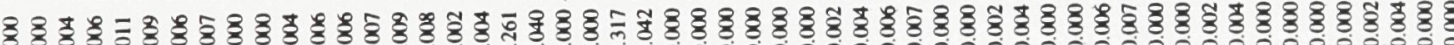

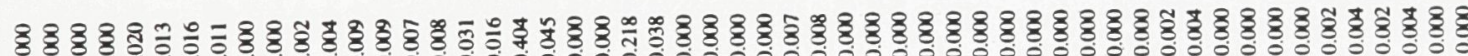

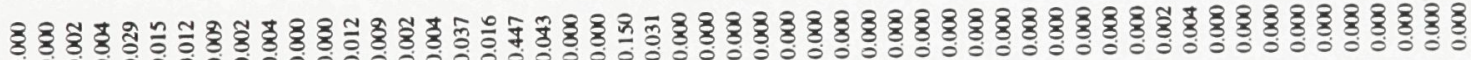
צ. (2)

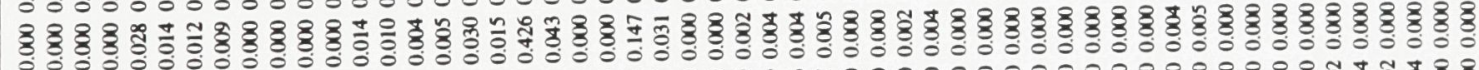

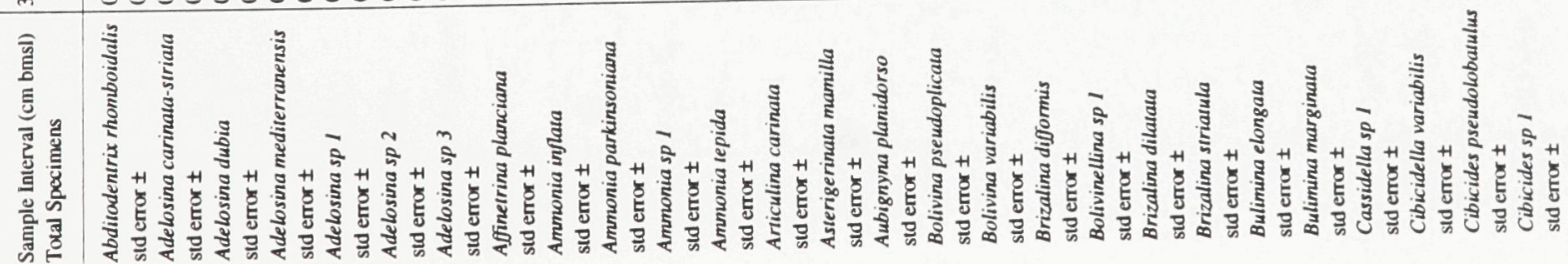




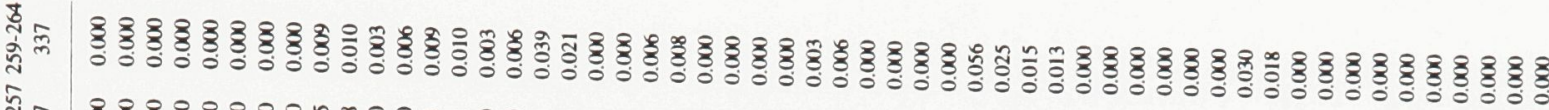

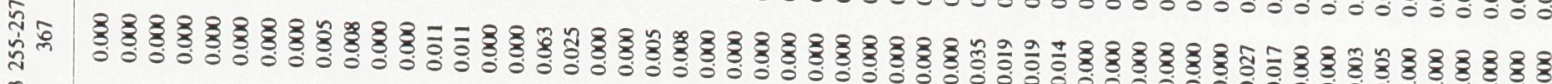

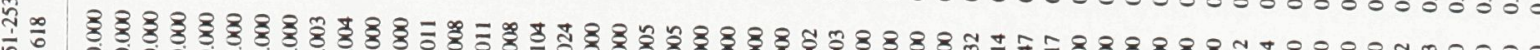
商。

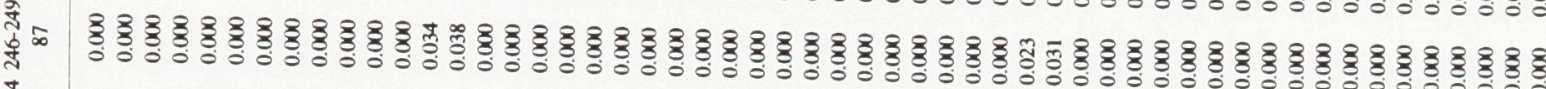

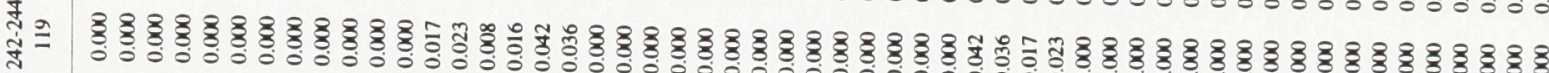
年

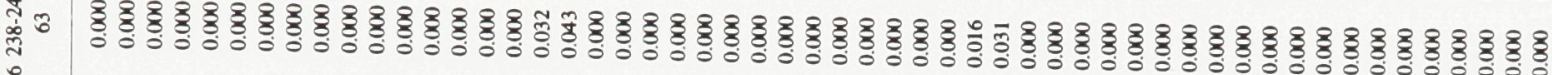

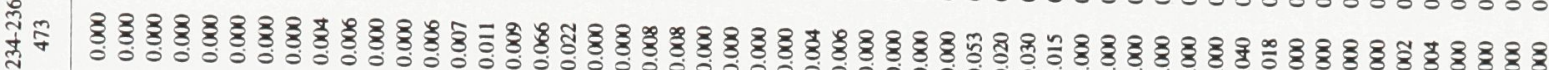
4.

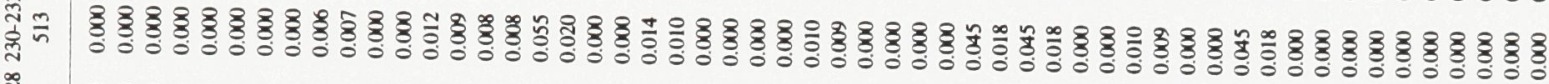

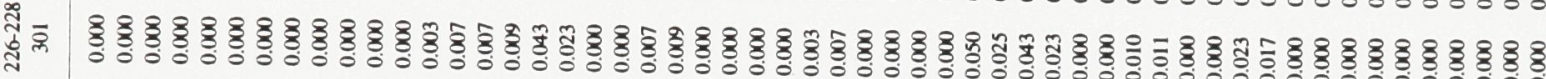

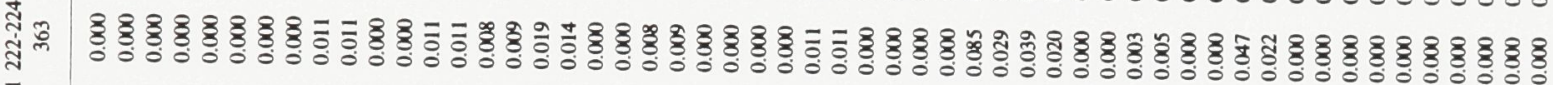

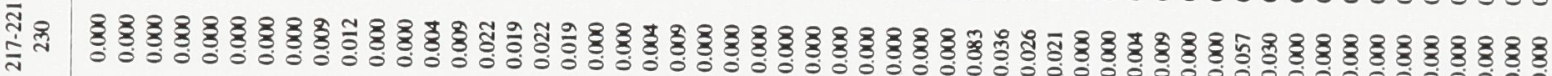

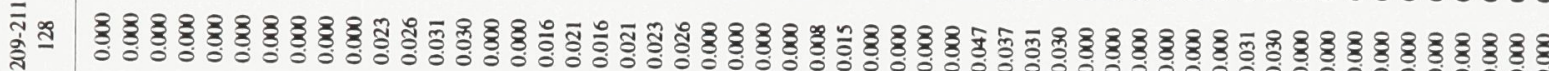

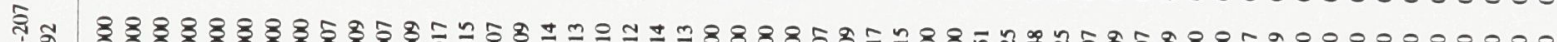
- 근

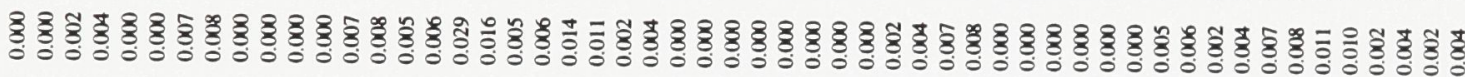

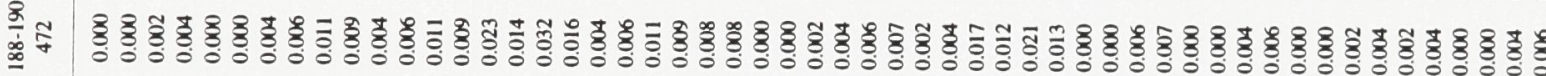

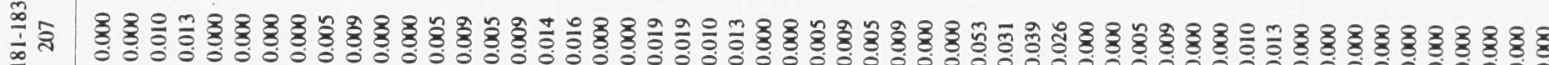

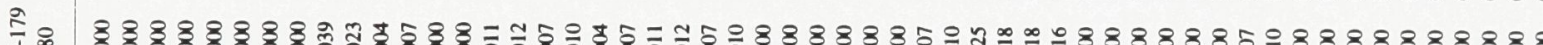

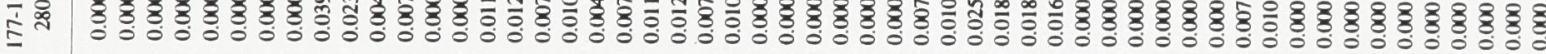

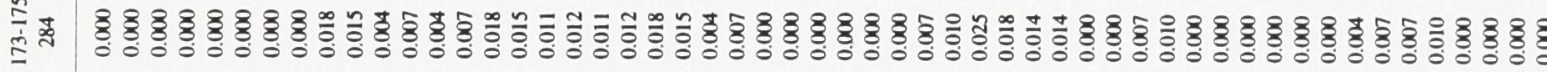
$\frac{8}{8}$ te

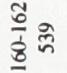

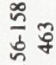

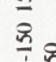
尊全 童品 等范

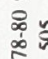

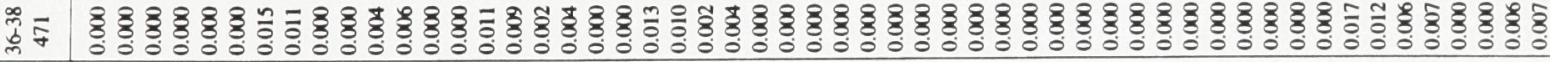

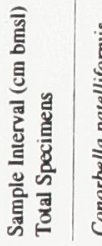

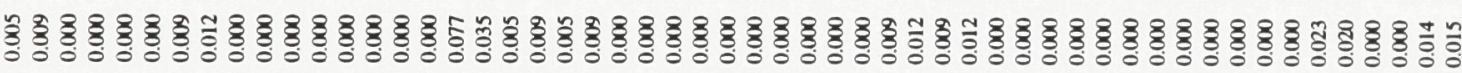

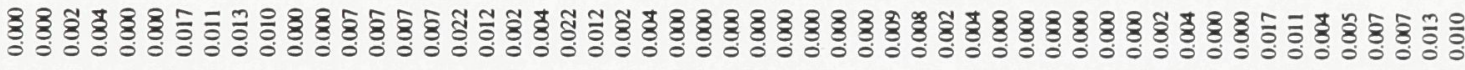

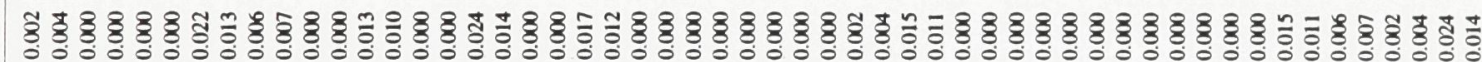

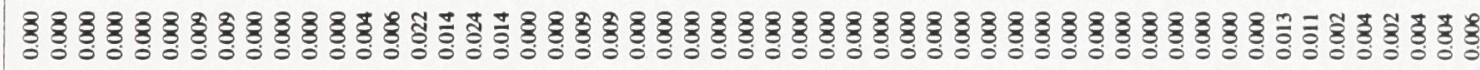

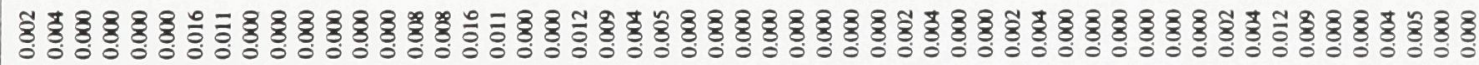

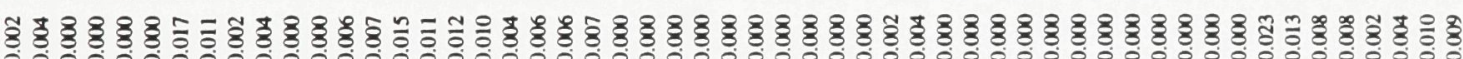
8.8

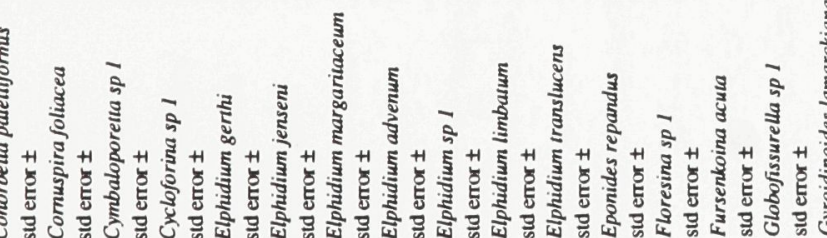
Mnd 


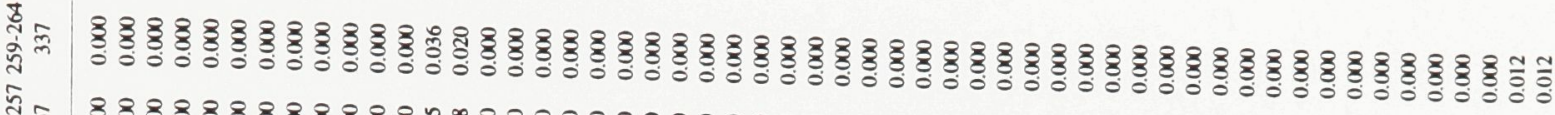

ปิ

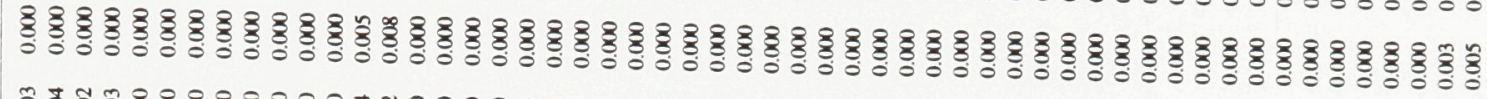

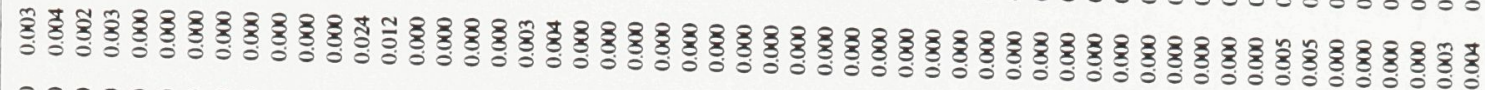

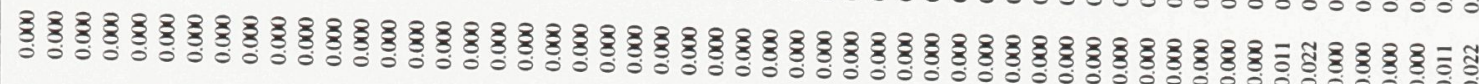

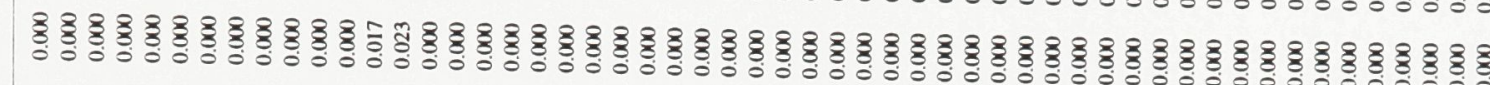

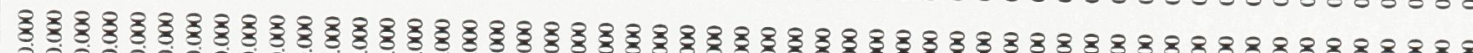

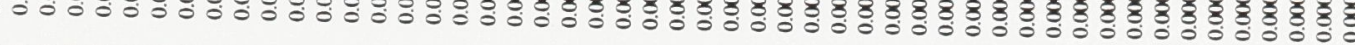

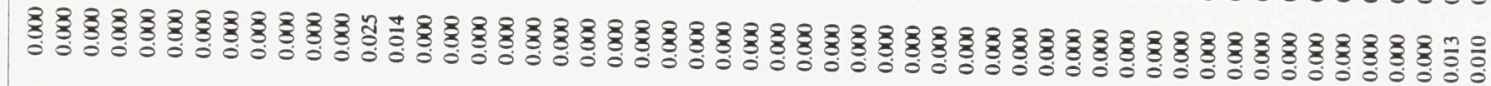

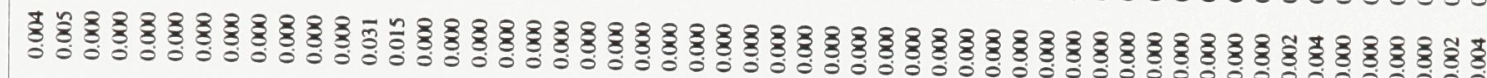

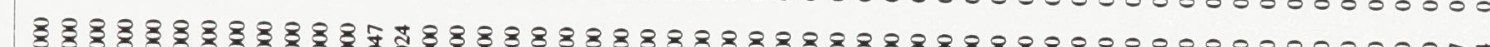
(1)

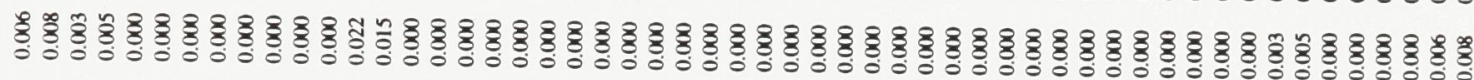

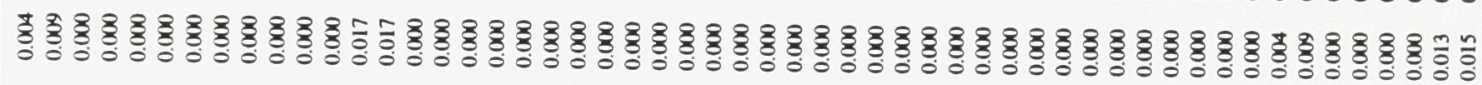

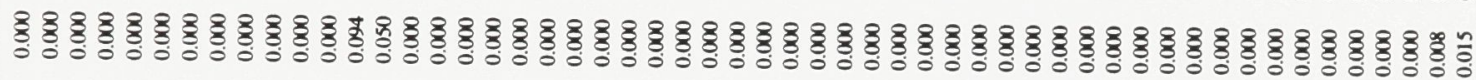

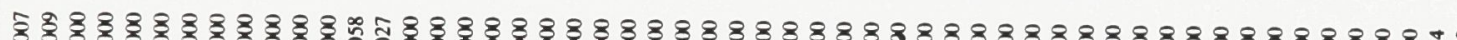

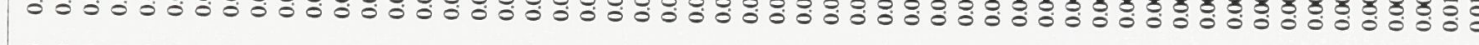

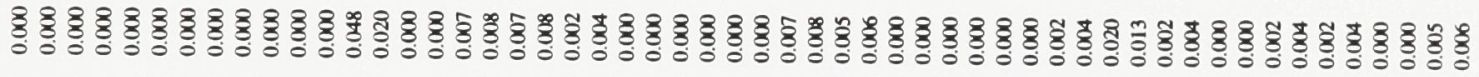

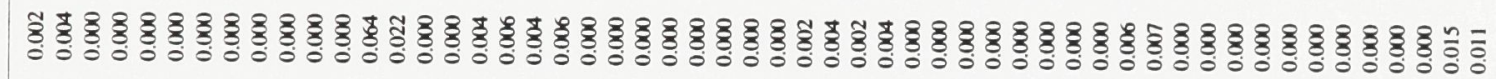

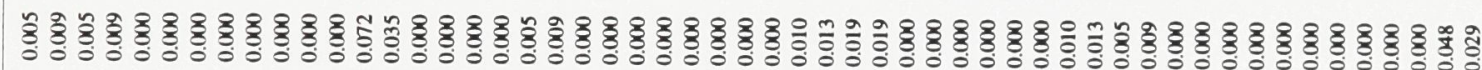

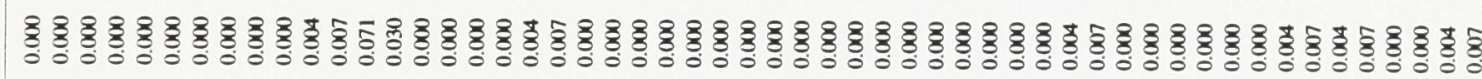

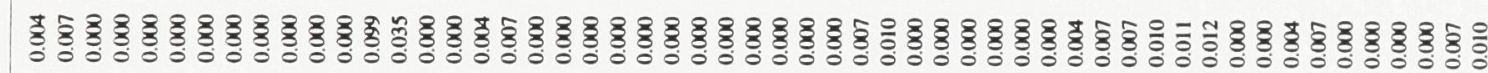

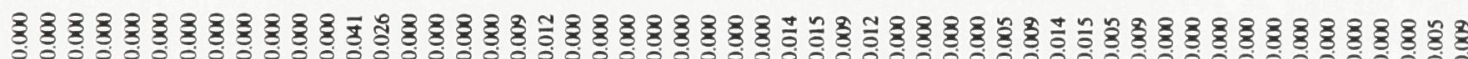

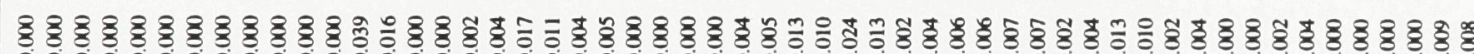

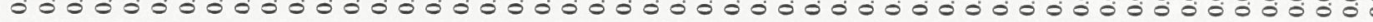

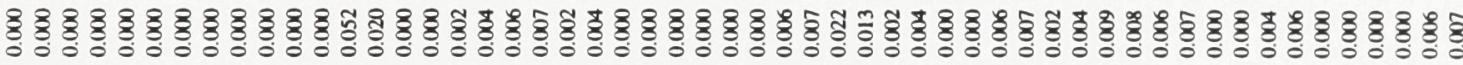

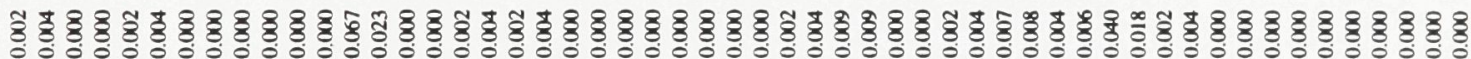

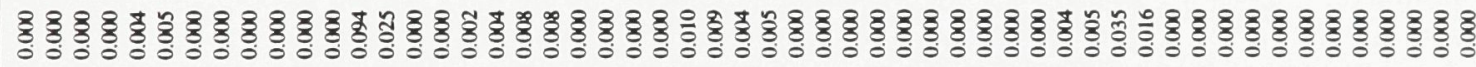

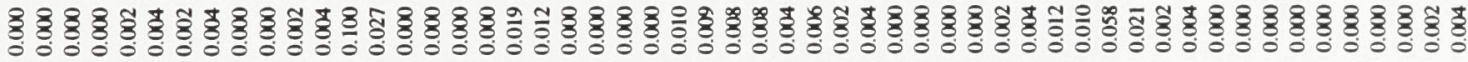

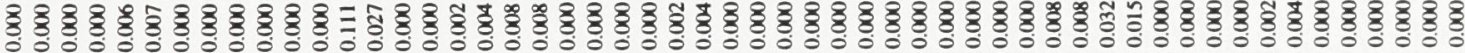

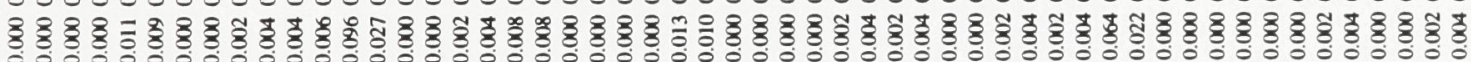




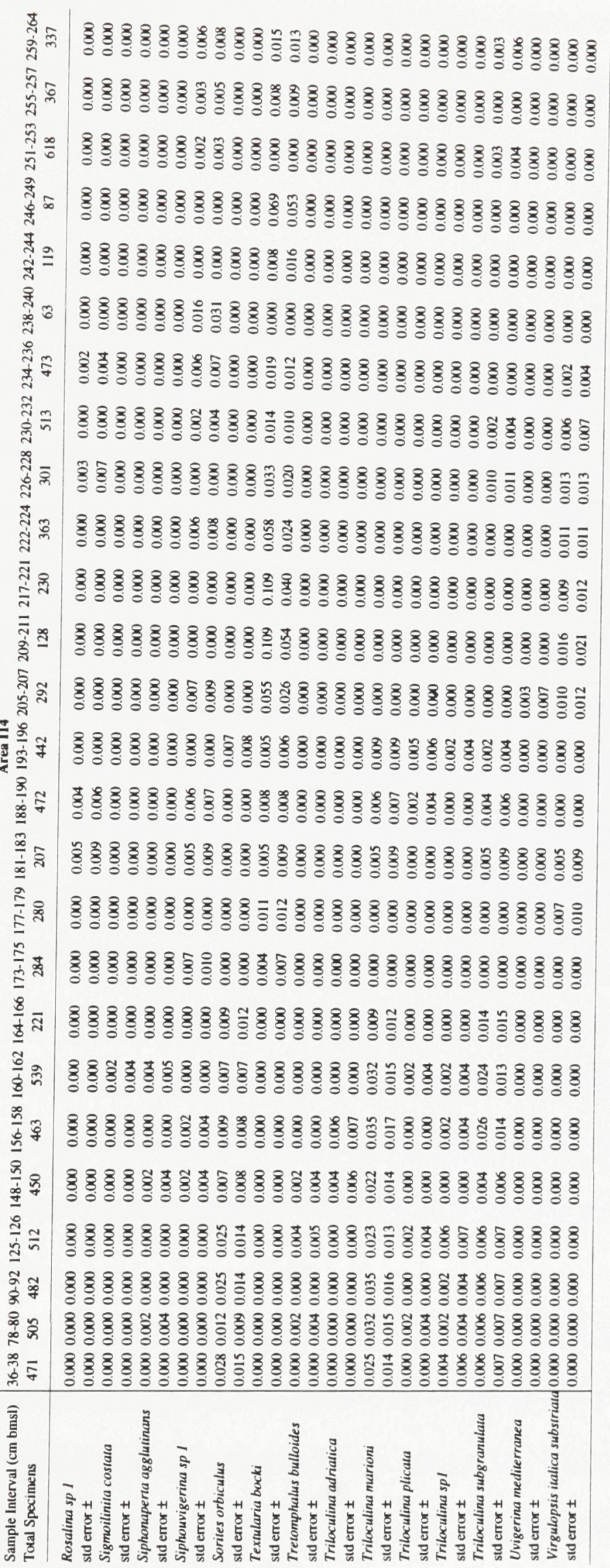


CONCLUSIONS

This doctoral dissertation resolved some of the many issues concerning the application of strontium isotopes as a paleosalinity indicator for paleoceanographic research. It determined that there was no vital effect associated with the uptake of strontium isotopes $\left({ }^{86} \mathrm{Sr}\right.$ and $\left.{ }^{87} \mathrm{Sr}\right)$ and it determined that the methodology could be effectively and reliably applied to coastal lagoon environments, but not to larger restricted basins. The findings of this dissertation built on existing research to expand the boundaries of $\mathrm{Sr}$ isotope $\left({ }^{87} \mathrm{Sr} / \mathrm{Sr}^{86}\right)$ research by providing an understanding of the potential uses, strengths, and weaknesses of the methodology as a paleosalinity indicator in various environments. No longer will strontium isotope research be associated solely with chronostratigraphic determinations.

The vital effect study (Chapter 1) determined that there was no biological discrimination between ${ }^{87} \mathrm{Sr}$ and ${ }^{86} \mathrm{Sr}$ isotopes, thus indicating that any deviation in the ${ }^{87} \mathrm{Sr} / 86 \mathrm{Sr}$ ratios found in bioprecipitates is due to diagenesis or the influence of foreign sources of Sr (fluvial or hydrothermal). Additionally, by conducting this study first and using it as a basis for following research, it provided confidence for the interpretation of the ${ }^{87} \mathrm{Sr} /{ }^{86} \mathrm{Sr}$ results from the Trubi $\mathrm{fm}$ and from Israel. These results proved that there is no vital effect associated with the uptake of $\mathrm{Sr}$ isotopes in bioprecipitaes, a factor which was previously only assumed by other researchers. Since there was no resolvable vital effect, the analyses of forty samples from the Bahamas, which was far removed from any continental riverine or hydrothermal influence, provided a good estimate of the ${ }^{87} \mathrm{Sr} / 86 \mathrm{Sr}$ value for modern seawater.

With regard to the application of the strontium isotope $\left({ }^{87} \mathrm{Sr} / 86 \mathrm{Sr}\right)$ methodology, this dissertation proved conclusively that the application of the $\mathrm{Sr}$ isotope $\left({ }^{87} \mathrm{Sr} / 86 \mathrm{Sr}\right.$ ) method as a paleosalinity indicator in large restricted basins is not effective. The initial results from the Trubi fm (Precariti section) of the Pliocene Mediterranean appeared to indicate a dilution of seawater by riverine sources during marl deposition. However, 
subsequent analysis of another section of the Trubi fm (Monta Singa section) proved that the original results could not be replicated. Detailed trace element and isotopic analyses of the various components of the marls and limestones revealed diagenetic alteration of the coccoliths. This subsequent detailed investigation indicated that the original results from the Precariti section were due to improper cleaning of the foraminiferal calcite. This detailed research from the Trubi fm indicated that the ${ }^{87} \mathrm{Sr} /{ }^{86} \mathrm{Sr}$ isotope methodology did not prove to be a useful proxy in large restricted basins. Unfortunately, since the ${ }^{87} \mathrm{Sr} / 86 \mathrm{Sr}$ isotope methodology did not work in application to the Trubi fm none of the issues associated with the origin of the marl/limestone couplets were resolved as originally intended. However, the research did indicate some of the diagenetic alterations that are important for the interpretation of past, present, or future isotopic geochemical results, and it emphasized the care that must be taken in the selection and preparation of sample material for ${ }^{87} \mathrm{Sr} /{ }^{86} \mathrm{Sr}$ determinations to prevent diagenetic contamination.

In contrast to the inapplicability of the methodology to a large restricted environment (ie Mediterranean), the application of the strontium isotope methodology to a restricted coastal lagoon environment (Caesarea Maritima) did prove to be an effective and useful high resolution paleosalinity proxy. The combined micropaleontological/strontium isotope research on the inner harbor at Caesarea recognized changes in the restriction of a lagoonal environment. The subtlety of the salinity changes would not have been as evident or as reliably indicated using only micropaleontological data. The use of ${ }^{87} \mathrm{Sr} / 86 \mathrm{Sr}$ isotope methodology provided much more detailed results and provided insights into the archaeological history of the form and function of the inner harbour. While the methodology was determined to be useful in application to a man-made restricted environment, it was also concluded that the combined methodology could be used in studies of naturally formed coastal lagoon environments to determine changes in restriction and possibly climatic variation through changes in the influx of freshwater. 
The intention of this dissertation was to provide future researchers with a more advanced and comprehensive understanding of the potential uses of strontium isotope $\left({ }^{87} \mathrm{Sr} / 86 \mathrm{Sr}\right)$ methodology. This goal was accomplished and the results may lead future researchers to continue to explore the application of this methodology as a proxy in other natural and man-made restricted lagoonal environments. Researchers may also work to determine the threshold for accuracy in an environment which lies between a restricted lagoon such as Caesarea and the marginal marine environment of the Mediterranean. The emphasis on avoiding diagenetic contamination of samples may also lead to new developments in analytical methodology. The diagenetic study of the Trubi fm will raise awareness of the potential contaminantion of ${ }^{87} \mathrm{Sr} /{ }^{86} \mathrm{Sr}$ results which will increase the reliability of the methodology as a paleosalinity proxy. Finally, the study of vital effects associated with $\mathrm{Sr}$ isotopes $\left({ }^{86} \mathrm{Sr}\right.$ and $\left.{ }^{87} \mathrm{Sr}\right)$ will provide researchers with a reliable and sound study upon which they may dismiss a strontium isötope vital effect in bioprecipitates. 